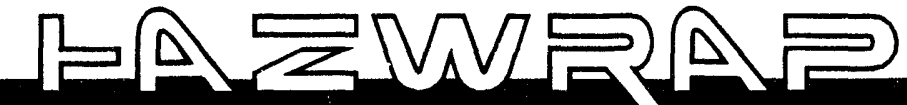 \\ HAZARDOUS WASTE REMEOIAL ACTIONS PROGRAM
}

Leading the Way to Environmental Stewardship

\section{An Assessment and Evaluation for Recycle/Reuse of Contaminated Process and Metallurgical Equipment at the DOE Rocky Flats Plant Site - Building 865}

\section{August 1993}

\author{
DISCLAIMER
}

\begin{abstract}
This report was prepared as an account of work sponsored by an agency of the United States Government. Neither the United States Government nor any agency thereof, nor any of their employees, makes any warranty, express or implied, or assumes any legal liability or responsibility for the accuracy, completeness, or usefulness of any information, apparatus, product, or process disclosed, or represents that its use would not infringe privately owned rights. Reference herein to any specific commercial product, process, or service by trade name, trademark, manufacturer, or otherwise does not necessarily constitute or imply its endorsement, recommendation, or favoring by the United States Government or any agency thereof. The views and opinions of authors expressed herein do not necessarily state or reflect those of the United States Government or any agency thereof.
\end{abstract}

Prepared by

Theta Technologies, Inc. subcontract $62 \mathrm{~K}-\mathrm{MD} 463 \mathrm{~V}$

HAZARDOUS WASTE REMEDIAL ACTIONS PROGRAM

Environmental Restoration and Waste Management Programs Oak Ridge, Tennesece 37831-7606

managed by MARTIN MARIETTA ENERGY SYSTEMS, INC.

for the DEPARTMENT OF ENERGY

under contract DE-AC05-840R21400 


\section{Final Report}

An Assessment and Evaluation for Recycle/Reuse of Contaminated Process and Metallurgical Equipment at the DOE Rocky Flats Plant Site - Building 865

Prepared by:

Theta Technologies, Inc. Oak Ridge, Tennessee

Prepared for:

Martin Marietta Energy Systems, Inc. Hazardous Waste Remedial Action Program Oliver Springs, Tennessee Under Subcontract No. 62K-MD463V

August 1993 


\section{Preface}

The U.S. Department of Energy (DOE) is evaluating the future mission for the Department's Weapons Complex in order that the goal of restoring the sites may be reached within the thirty years set by the Office of Environmental Restoration and Waste Management. Among other efforts, the cleanup will require decontamination and decommissioning of facilities used for research, development, production, testing, analysis, and storage.

The Decontamination and Decommissioning Program within the Office of Technology Development initiated a pilot project to assess and evaluate benefits of recycle, reuse, and resale for various equipment and materials associated with Building 865 at the Rocky Flats Plant Site, a research and development metallurgical facility there that has been shut down and designated for decontamination and decommissioning. The following document presents comparisons of the economies relative to disposal options for the waste that would be generated from a decontamination and decommissioning effort of Building 865 .

Baseline costs were established for disassembly and burial of the metallurgical and process equipment in the building. Costs for this option were compared to three alternatives: (1) recycling as either scrap or as smelted metal; (2) reuse and resale within the government sector; and (3) resale for use in the private sector.

Two cost estimates for the baseline, landfill disposal alternative were developed to reflect the upper and lower boundaries for landfill fees. The upper boundary is based on costs derived from the use of landfill space at current commercial rates, and the lower boundary is based on the use of landfill space at current government rates. Similarly, cost estimates for each of the three alternatives were developed to reflect this great disparity in landfill fees, because each of the three alternatives involves the disposal of some material that is not suitable for the reuse or recycle option under consideration.

The results of comparing the recycle/reuse alternatives to the baseline (landfill alternative) indicated potential cost savings ranging from a low of $\$ 1,346,200$ (yielded by comparing the smelting alternative to the baseline using government disposal rates for both estimates) to $\$ 25,600,000$ (yielded by comparing the government transfer alternative to the baseline using commercial disposal rates for both estimates).

The following document outlines the methodology used for the development of costs and comparisons. Applicable federal and state regulations were incorporated, and a discussion of current policies and potential impacts has been included. 
-

○

- 


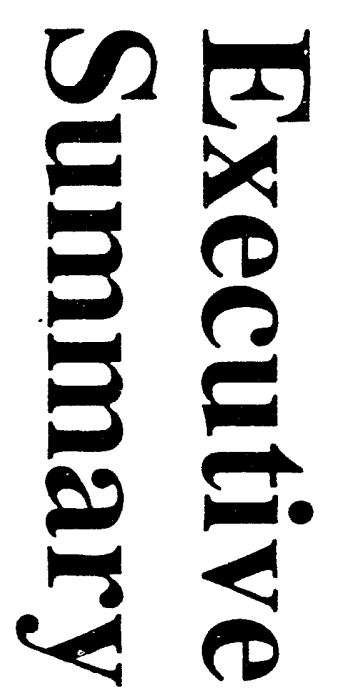




\section{Executive Summary}

An economic analysis of the potential advantages of alternatives for recycling and reusing equipment now stored in Building 865 at the Rocky Flats Plant (RFP) in Colorado has been conducted. The inventory considered in this analysis consists primarily of metallurgical and process equipment used before January 1992, during development and production of nuclear weapons components at the site. The economic analysis consists of a thorough building inventory and cost comparisons for four equipment disposition alternatives. The first is a baseline option of disposal at a Low Level Waste (LLW) landfill. The three alternatives investigated are metal recycling, reuse with the government sector, and release for unrestricted use.

The work documented in this report fits within the overall planning framework for decontamination and decommissioning (D\&D) at Rocky Flats. Specifically, the site's Transition Program Plan outlines specific plans for each building and states that an analysis shall be performed to determine the feasibility of releasing surplus equipment for unrestricted use. Complementing the Transition Program Plan is a general plant site D\&D Plan that identifies the factors to be considered in this building-by-building feasibility analysis for unrestricted release:

- Value of each item

- Cost of disposing

- Cost of decontamination

- Contributions to waste management goals

- Risk to the public

This report provides item-by-item estimates of value, disposal cost, and decontamination cost. The economic evaluation methods documented here, the simple cost comparisons presented, and the data base provided as a supplement, should provide a foundation for D\&D decisions for Building 865, as well as for similar D\&D tasks at RFP and at other sites.

Two total costs are reported for disposing of all Building 865 equipment at a LLW landfill: $\$ 4,854,000.00$ and $\$ 33,130,000.00$. The first, much lower figure is based on assumptions of a contractor-provided work crew of 57, a support staff of 8 , and a staff management team of 3 employed full-time over the course of two years. Note that disposal costs for this figure were calculated using a government rate of $\$ 10 / \mathrm{ft}^{3}$. The second figure is based on the same staff and project duration assumptions, but on a much higher commercial disposal rate of $\$ 400 / \mathrm{ft}^{3}$. Using this figure is an attempt to more thoroughly to account for costs that the government is likely to incur in disposing any or all of the RFP equipment, including the cost of closure, remediation, and the development of a landfill that adheres to strict construction and performance standards.

To determine the economic advantages of implementing the recycle/reuse alternatives instead of the baseline option, the decrease in cost was determined for each alternative. For each of the recycle/reuse alternatives-metal recycling, reuse within the government sector, and release for unrestricted use-estimates were formulated according to the following general methodology: 
- Determine pieces of equipment suitable as candidates for each alternative, based on relevant factors such as degree of contamination, condition of equipment, potential market demand, and others.

- Estimate cost of necessary disassembly, decontamination, reassembly, or other cost elements, as well as potential revenue, for each piece of candidate equipment using assumptions detailed later in this report.

- Estimate disposal costs for non-candidate equipment using both governmental and commercial disposal rates, as was done in the estimate for the baseline option.

The total estimated costs for each of the alternatives represents the total potential for revenue generated by the qualifying equipment or material for that option minus the cost to dispose of any remaining equipment or material.

Once two total estimated costs for each option were generated (the first using the government disposal rate and the second using the commercial disposal rate), all were compared to the costs of the baseline, landfill disposal alternative. These simple comparisons identify the alternatives with the greatest potential for cost savings.

This report compares alternatives based on the rather unrealistic assumption that the selection of one of the three alternatives for disposition precludes the use of the other two. Of course, this is not the case. Maximizing the potential for cost savings or revenue generation will no doubt involve a combination of all of the options considered here.

All options offer a decrease in the total cost to the government compared to the baseline landfill option. See Figures S.1 and S.2 below. Assuming the use of a government waste disposal site, the range of cost savings is $\$ 1,827,500(38 \%)$ for transfer within the government to $\$ 1,346,200$ (28\%) for recycling smelted metal. When using the commercial disposal rate to estimate costs for the baseline and alternatives, each of the three recycle/reuse alternatives offers a potential cost savings of approximately $\$ 25,000,000$ compared to the landfill disposal option.

The results of economic analyses presented here provide preliminary information that should prove useful to staff members at RFP in beginning to develop plans for the final disposition of Building 865 equipment. Another crucial component of final decision-making includes consideration of current and proposed policies that deal with disposition of equipment-particularly unrestricted release.

Planners and policy makers will find that the majority of impediments to implementing the most attractive economic alternatives, in combinations that will optimize savings, relate to current policies and institutional reluctance.

While current guidance in DOE Order 5400.5 does not clearly indicate requirements for restricted and unrestricted release criteria, a newly proposed rule, 10 CFR 834, does. Of particular interest to this economic analysis is the provision for free release of equipment previously used in radiation areas. Also of interest is the provision for determination of limits for volumetric, as well as surface contamination. (The process of determining volumetric contamination limits is illustrated in Section 3.1 of this report.) International experience provides examples of release limits used in various situations that may inform the process of establishing criteria for free release in the U.S. 
Figure S.1 Cost Comparision of Baseline and Alternatives

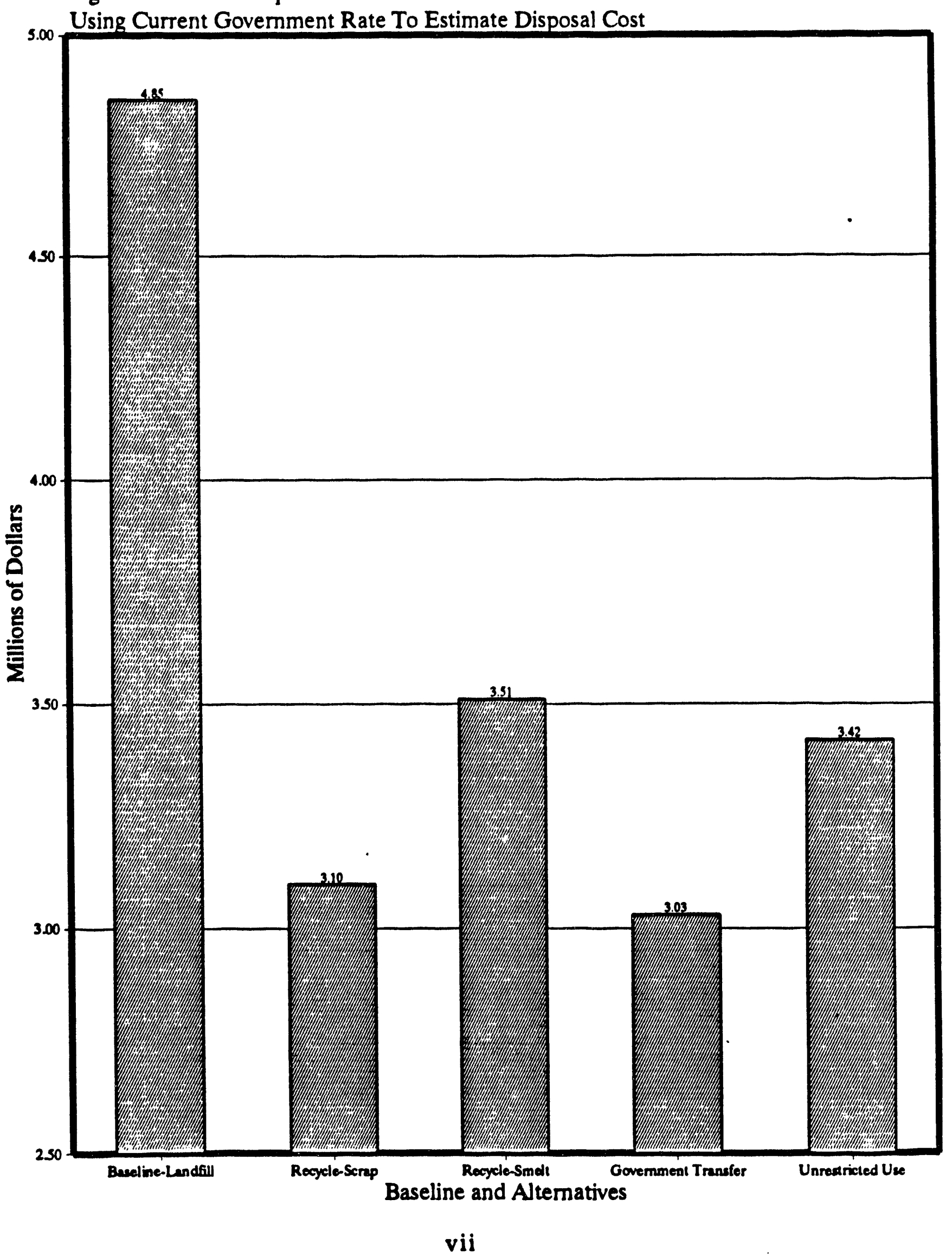


Figure S.2 Cost Comparison of Baseline and Alternatives

Using Current Commercial Rate to Estimate Disposal Costs

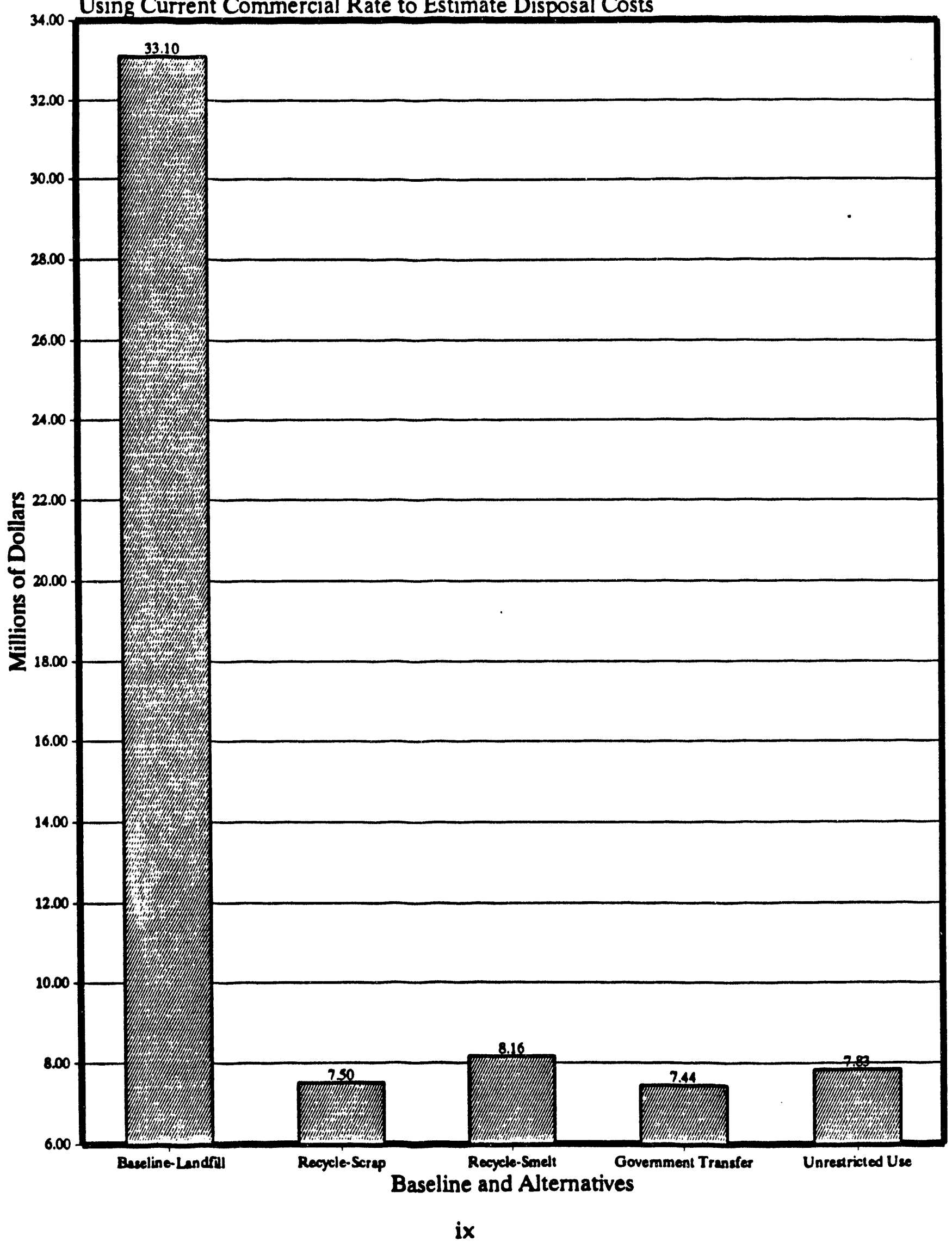




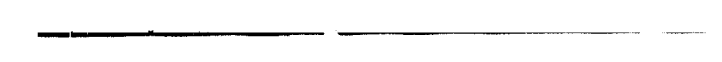

-

○ 
The proposed rule appears to reinforce the aims of D\&D, including the ALARA principle, environmental compliance, and waste minimization. However, the culture at some DOE sites appears to stand in the way of achieving these aims within the proposed regulatory framework. In particular, institutional controls at RFP appear to reflect both overly cautious and sometimes erroneous interpretations of current DOE guidance and, to an even greater degree, reluctance to embrace the proposed guidance.

Clearly, the optimal cost savings to the government for the equipment disposition challenges that will be the focus of a great deal of work into the next century will involve establishing and enforcing policies that accomplish two objectives. First is protecting the public in accordance with accepted risk factors. Second is encouraging DOE sites to realistically consider several recycle/reuse alternatives for each piece of equipment. Related to this second objective is the need for training and other measures to overcome largely unexamined biases against unrestricted release of previously contaminated equipment that stem from the fear of liability and other historical features of the DOE culture.

A computerized, cost estimating database has been developed to allow easy modifications as assumptions are further refined. The disc provided with this report is intended for use with any DOS-based computer (version 4.0 or higher and $2 \mathrm{MB}$ of RAM). In addition, the disc includes a FoxPro Run-time Library, and therefore, purchase of FoxPro database software is not required. Input screens allow the user to easily change values for the variable multipliers, such as labor rates, burial costs, and decontamination costs, while fixed values such as weight, volume, and surface area of equipment; labor estimates; equipment sales prices; and others remain constant. Simple output routines allow printing of "what-if" scenarios for data exploration, a function that will be useful in combining various alternatives to optimize the potential for cost savings and for waste minimization. 
ㅆ.

$\bullet$

$\bullet$ 


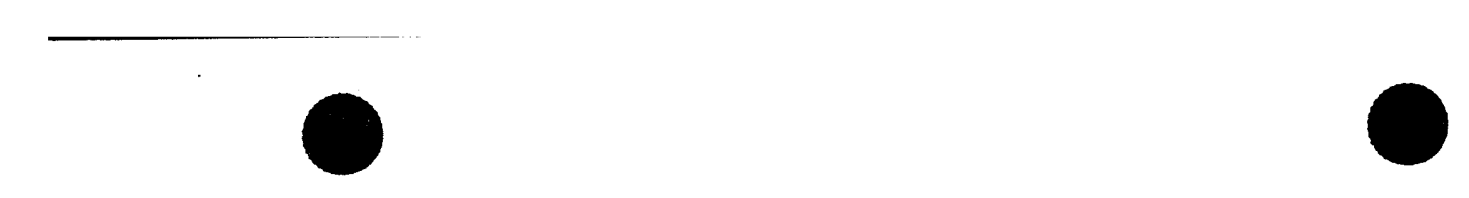

$\bullet$

$\Omega$

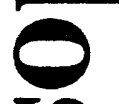

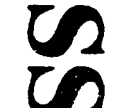

2 


\section{Glossary of Terms}

41 CFR 101-Federal regulation governing the disposition of surplus government equipment, including utilization, sale, abandonment, or destruction.

ALARA Principle-As Low as Reasonably Achievable (ALARA) is a phrase (acronym) used to describe an approach to radiation protection to control or manage exposures (both individual and collective to the work force and the general public) and releases of radioactive material to the environment as low as social, technical, economic, practical, and public policy considerations permit. ALARA is not a dose limit, but rather it is a process that has as its objective the attainment of dose levels as far below the applicable limits of the relevant regulations as possible.

baseline alternative-The baseline alternative, burial of Building 865 equipment, represents the "worst case scenario" from an economic standpoint. That is, for the purposes of the baseline estimate, all equipment is assumed to have no economic worth. Furthermore, it is assumed for this option that the cost of decontamination, and subsequent sampling and surveying to verify decontamination, is prohibitive. The total estimated cost for this option reflects the assumption that all Building 865 equipment would be removed directly to a LLW landfill.

decommissioning-The process of removing a facility from operation, which may include decontamination, entombment, dismantlement, or conversion to another use.

decontamination-The removal of unwanted material (typically radioactive material) from facilities, soils, or equipment by washing, chemical action, mechanical cleaning, or other techniques.

disposition-See entry for 41 CFR 101.

excess personal property-Any personal property under the control of any Federal agency which is not required for its needs and the discharge of its responsibilities, as determined by the head of that agency.

exposure-Contact with a chemical or physical agent.

Federal Disposal Condition Codes-Codes established in 41 CFR 101 used to determine the status or state of useability of Federally owned property.

free release-Property meeting strict "no contamination" criteria may be released with no restrictions on its future use.

government sector-As used in this document, any agency of the Federal government or any state or local government body. 


\section{Glossary of Terms (continued)}

inventory-As used in this report, that subset of the equipment and material in Building 865 at the Rocky Flats Plant Site considered for the baseline and recycle/reuse alternatives covered here.

Low Level Waste-Materials that are contaminated by less than $5 \times 10^{-5} \mu \mathrm{Ci} / \mathrm{ml}$ of mixed fission products.

recycling - Converting solid waste into new products by using the resources contained in discarded materials, including industrial scrap.

restricted use-As used in this document and in DOE Order 5400.5, DOE exercises its authority to release property from its control after confirming that residual radioactive material (over which DOE has authority) on the property has been determined to meet the guidelines for residual radioactive material in Chapter IV of the Order or any other applicable radiological requirements. There may be instances in which DOE or another authority will impose restrictions on the management and/or use of the property if the residual radioactive material guidelines of Chapter IV of the Order are not met or if other applicable Federal, state or local requirements cause the imposition of such restrictions.

reuse-The reintroduction of a waste material or product into the economic stream without any chemical or physical change.

risk assessment-A qualitative or quantitative evaluation of the environmental and/or health risks resulting from exposure to a chemical or physical agent (pollutant); combines exposure assessment results with toxicity assessment results to estimate risk.

scrap-Personal property that has no value aside from its basic material content.

surplus-Any excess personal property not required for the needs or for the discharge of responsibility of Federal agencies, as determined by the Administrator of General Services.

surface contamination-Radioactivity per unit surface area, expressed in disintegrations per minute.

Transition-The process of planning and carrying out the transfer to the Office of Environmental Restoration and Waste Management (EM) of production plants undergoing a mission change. Transition involves safely deactivating unneeded facilities and overseeing their smooth transfer to EM, where they may be either cleaned up or prepared for reuse. 


\section{Glossary of Terms (continued)}

unrestricted use-See "free release."

volumetric contamination-Radioactivity per unit volume or mass in equipment and material resulting from years of use in radiation areas. Expressed as a mass concentration. 


.




\section{Acronyms}


Abbreviations and Acronyms

As Low As Reasonably Achievable

Atomic Energy Commission

Below Regulatory Concern

Becquerel

Bureau of National Affairs

ALARA

AEC

BRC

$\mathrm{Bq}$

Code of Federal Regulations

BNA

Comprehensive Environmental Response

CFR

Compensation and Liability Act

Decontamination and Decommissioning

disintegrations per minute

direct numerical control

Environmental Restoration and Waste Management

feet

Fiscal Year

Health and Safety I-Ian

inches

high efficiency particulate air (filter)

International Atomic Energy Agency

International Commission on Radiological Protection

Low Level Waste

Low Specific Activity

Management and Operating

Mega Watt

Memorandum of Understanding

micro Curie

micro Sievert

milli Sievert

CERCLA

D\&D

dpm

DNC

EM

ft.

FY

HSP

in.

HEPA

IAEA

ICRP

LLW

LSA

$M \& O$

$\mathrm{MW}$

MOU

$\mu \mathrm{Ci}$

$\mu S v$

$\mathrm{mSv}$

millirem

mrem

nano Curies

$\mathrm{nCi}$

National Priorities List

NPL

Nevada Test Site

NTS

Nuclear Regulatory Commission

NRC

Office of Environmental Health and Safety

Percent of sealand container

EH-1

SL\%

Polychlorinated biphenyls

PCBs

Radioactive Material Management Area

RMMA

Radiological Controlled Area

RCA

Radiological Engineering

Radiological Operational Instructions

RE

Research and Development

ROI

Resource Conservation and Recovery Act

R\&D

RCRA 
Abbreviations and Acronyms (continued)

Rocky Flats Plant

RFP

Transition Program, U.S. Department of Energy

EM-60

Toxic Substance Control Act

TSCA

unrestricted use

U.S. Environmental Protection Agency

U.S. Department of Defense

U.S. Department of Energy

URU

EPA

DOD

DOE

U.S. Department of Transportation

DOT

vertical turret lathe

VTL

year

yr. 


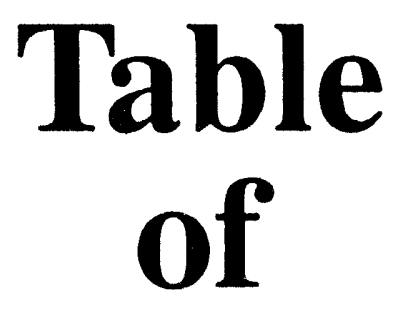

-

Contents 


\section{Table of Contents}

Preface iii

Executive Summary v v

Glossary of Terms $\quad$ xiii

Abbreviations and Acronyms xvii

List of Figures $\quad$ xxiii

List of Tables $\quad$ XXV

1.0 Introduction 1

1.1 Economic Analysis Methodology-Overview 2

1.2 Policy Implications-Overview 5

1.3 Equipment-Overview 9

2.0 Economic Analysis of Alternatives for Disposition 17

2.1 Baseline Alternative-Landfill Disposal 17

2.1.1 Assumptions Underlying the Landfill Disposal Alternative 17

2.1.2 Elements of the Landfill Disposal Cost Analysis 18

2.1.2.1 Cost of Removal and Disposal of Hydraulic and Coolant Oils 18

2.1.2.2 Cost of Labor and Equipment for Disassembly and Removal to a Staging Area 21

2.1.2.3 Cost of Additional Disassembly, Cutting, and/or Shredding Necessary for Packaging 21

2.1.2.4 Cost of Shipping Containers and Transportation 21

2.1.2.5 Landfill Fees and Surcharges 21

2.1.2.6 Cost of Management and Regulatory Compliance 22

2.1.3 Summary of the Land Disposal Cost Estimate 22

2.2 Metal Recycling 25

2.2.1 Assumptions Underlying the Metal Recycling Alternatives 25

2.2.2 Elements of the Metal Recycling Cost Analysis 26

2.2.2.1 Cost of Removal and Disposal of

Hydraulic and Coolant Oils

26

2.2.2.2 Cost of Labor and Equipment for Disassembly and Removal to a Staging Area 26

2.2.2.3 Cost of Additional Disassembly and Segregation to Prepare for Decontamination or Smelting 26

2.2.2.4 Cost of Decontamination of Scrap Metal for Unrestricted Release

2.2.2.5 Cost of Sampling and Survey 31

2.2.2.6 Cost of Smelting 31

2.2.2.7 Cost of Shipping Containers and Transportation 32

2.2.2.8 Landfill Fees and Surcharges 32

2.2.2.9 Cost of Management and Regulatory Compliance 32

2.2.2.10 Metal Value 32 


\section{Table of Contents (continued)}

2.2.3 Summary of the Metal Recycling Cost Estimates 33

2.3 Reuse Within the Government Sector 35

2.3.1 Assumptions Underlying the Reuse Alternative 35

2.3.2 Elements of the Reuse Cost Analysis 36

2.3.2.1 Cost of Removal and Disposal of Hydraulic and Coolant Oils $\quad 36$

2.3.2.2 Cost of Labor and Equipment for Disassembly and Removal to a Staging Area 36

2.3.2.3 Cost of Additional Disassembly for Decontamination 36

2.3.2.4 Cost of Decontamination of Equipment for Transfer 41

2.3.2.5 Cost of Reassembly 42

2.3.2.6 Cost of Sampling and Survey 42

2.3.2.7 Cost of Shipping Containers and Transportation 42

2.3.2.8 Landfill Fees and Surcharges 42

2.3.2.9 Cost of Management and Regulatory Compliance 42

2.3.3 Summary of the Reuse Cost Estimate 43

2.4 Unrestricted Sale to Non-Government Organizations 45

2.4.1 Assumptions Underlying the Unrestricted Sale Alternative 45

2.4.2 Elements of the Unrestricted Sale Cost Analysis 45

2.4.2.1 Cost of Removal and Disposal of Hydraulic and Coolant Oils

2.4.2.2 Cost of Labor and Equipment for

Disassembly and Removal to a Staging Area 46

2.4.2.3 Cost of Additional Disassembly for Decontamination 46

2.4.2.4 Cost of Decontamination of Equipment for Unrestricted Release $\quad 46$

2.4.2.5 Cost of Reassembly 46

2.4.2.6 Cost of Sampling and Survey 46

2.4.2.7 Cost of Shipping Containers and Transportation 46

2.4.2.8 Landfill Fees and Surcharges 46

2.4.2.9 Cost of Management and Regulatory Compliance 46

2.4.2.10 Cost to the Government for Conducting the Sale 49

2.4.2.11 Revenue Generated by the Sale 50

2.4.3 Summary of the Unrestricted Sale Cost Estimate 51

2.5 Comparison of Economic Alternatives 52

2.5.1 Overview of Potential Cost Savings Compared
to Baseline Alternative

2.5.2 Uncertainties 52 
Table of Contents (continued)

3.0 Policy Implications 55

3.1 U.S. Department of Energy Guidance 55

3.2 International Experience 61

3.2.1 International Commission on Radiological Protection 61

3.2.2 International Atomic Energy Agency 62

3.2.3 International Criteria for Unrestricted Release 62

3.3 U.S. Environmental Protection Agency Involvement 65

3.4 Nuclear Regulatory Commission Position 65

3.5 State of Colorado 66

3.6 Rocky Flats Plant Guidance Interpretations 67

3.7 Regulations for the Transportation of Radioactive Materials 68

$\begin{array}{ll}\text { References } & 73\end{array}$ 
Table of Contents (continued)

Appendices

Appendix A- Methodology

A.1 Baseline Alternative-Landfill Disposal A-1

A.2 Metal Recycling A-2

A.3 Reuse Within the Government Sector A-3

A.4 Unrestricted Release to Non-Government Organizations A-4

Appendix B-Data Base Information

B.1 General Equipment Data B-1

B.2 Baseline Cost Data B-10

$\begin{array}{lll}\text { B.3 Recycle/Reuse Cost Data } & \text { B-17 }\end{array}$

Appendix C-Staging and Decontamination Area Cost C-1

Appendix D-Cost Backup Documentation
D.1
Equipment Decontamination and Carbon Dioxide Cleaning
D-1
D.2 Methodology for Estimating Fair Market Value
D-2
D.3 Equipment Removal Assumptions and
D.4 PCB Oil Disposal
D.5 Equipment Burial
D.6 Smelting Option
D.7 Management and Regulatory Compliance Cost
D.8 Cost for Surveying
D-8
D.9 Packaging for Reuse or Resale

Appendix E-Federal Regulations Applicable to Disposition of Equipment

Appendix F-Government Reuse Equipment Lists

F.1

Equipment List for Government Reuse-Contaminated

F-1

F.2

Equipment List for Government Reuse-Decontaminated

F-2 


\section{List of Figures}

Figure S.1

Figure S.2

Figure 1.2

Figure 2.1

Figure 2.2a

Figure 2.2b

Figure 2.3a

Figure 2.3b

Figure 2.4
Cost Comparison of Baseline and Alternatives Using Current Government Rate to Estimate Disposal Cost

vii

Cost Comparison of Baseline and Alternatives Using Current Commercial Rate to Estimate Disposal Cost

ix

Surplus Equipment Process Flow Diagram

7

Cost Elements for Baseline AlternativeLand Disposal

Cost Elements for Metal Recycling-Scrap

Cost Elements for Metal Recycling-Smelting

Cost Elements for Reuse Within the

Government Sector-Decontaminated

Cost Elements for Reuse Within the Government Sector-Contaminated

Cost Elements for Unrestricted Sale to Non-Government Organizations 


\section{List of Tables}

Table 1.1a

Table 1.1b

Table 1.3

Table 2.1

Table 2.2a

Table 2.2b

Table 2.3

Table 2.4a

Table 2.4b

Table 2.5

Table 3.1

Table 3.2

Table 3.7a

Table 3.7b

Table 3.7c
Assumptions Underlying Cost Estimates

for Baseline and Alternatives

3

Comparison of Economic Alternatives 4

Overview of Equipment Classes

and Likely Disposition

11

Cost Summary for Baseline Alternative 23

Cost Summary for Metal Recycling-Scrap 33

Cost Summary for Metal Recycling-Smelting

Cost Summary for Reuse

within the Government Sector

Rocky Mountain Equipment Brokers

Cost Summary for Unrestricted Sale to Non-Government Organizations

Comparison of Economic Alternatives

Sample Calculation to Establish Authorized or Supplemental Limits for Volumetric

Contamination for Unrestricted

Equipment Release

International Release Criteria

Sources of Federal Regulations Regarding

Transportation of Radioactive Material

Maximum Radiation Levels Limitations

for Packaging and Transportation

Contarnination Limits for Removable Surface

Contamination for Transport (49 CFR 173.443) 
希

○ 


\subsection{Introduction}

The U.S. Department of Energy (DOE) Headquarters Office of Technology Development has conducted an economic analysis of the potential advantages of alternatives for recycling and reusing equipment now stored in Building 865 at the Rocky Flats Plant (RFP) in Colorado. The inventory consists primarily of metallurgical and process equipment used before January 1992, during production of nuclear weapons components at the site. Briefly, this economic analysis consists of a thorough building inventory and cost comparisons for four equipment disposition alternatives: disposal at a Low Level Waste (LLW) landfill, metal recycling, reuse with the government sector, and release for unrestricted use. Details of the cost estimate calculations comprise Section 1.1 and Section 2.0 of this report.

Since 1992, the mission at RFP has been environmental cleanup. Beginning in FY 1993, responsibility for the site is being transferred from Defense Programs to Environmental Restoration and Waste Management (EM). As a part of the Transition Program (EM-60), the major focus for work at the site is on planning for Decontamination and Decommissioning (D\&D) of the various facilities.

The work documented in this report fits within the overall planning framework for D\&D at Rocky Flats. Specifically, the site's Transition Program Plan, which outlines specific plans for each building, states that an analysis shall be performed to determine the feasibility of release of the surplus equipment for unrestricted use. Complementing the Transition Program Plan is a general plant site D\&D Plan that identifies the factors to be considered in this building-by-building feasibility analysis for unrestricted release:

- Value of each item

- Cost of disposing

- Cost of decontamination

- Contributions to waste management goals

- Risk to the public

This report provides item-by-item estimates of value, disposal cost, and decontamination cost. In addition, a sample exposure scenario and calculated concentration limits in Section 3.1 illustrate the method for calculating standards for free release of volumetrically contaminated equipment. Seven steps in credible cost estimating and planning for D\&D are documented in this report.

1.) Thorough on-site equipment characterization, verified by professional brokers to be sufficient for future needs.

2.) Field research to determine the market value of equipment and scrap.

3.) Comprehensive formulation of computational models for each disposition alternative, developed by personnel with years of experience with similar equipment at DOE facilities.

4.) Documentation of site-specific cost estimates by personnel familiar with DOE facilities and operations. These estimates include:

Activity-dependent costs directly relating to worker's hands-on activities to disassemble, package, decontaminate, etc.

Period-dependent costs reflecting contractor and staff costs to manage programs through their duration 
Collateral costs encompassing capital equipment purchases, health physics supplies, energy, licenses, insurance, taxes, and permits Salvage and scrap values estimating the potential market value of equipment and scrap

Contingency costs including allowances for unanticipated cost overruns, such as rising disposal costs due to the limited availability of LLW landfill space and for the standard $30 \%$ contingency for fixed-price subcontractors

5.) Development of a data base to organize information and compute costs.

6.) Comparison of estimated costs to baseline, burial alternative.

7.) Consideration of policies and regulations that limit the implementation of economically attractive disposition alternatives.

The economic evaluation methods documented here, the simple cost comparisons presented, and the data base provided as a supplement, should provide a foundation for D\&D decisions for Building 865, as well as for similar D\&D tasks at RFP and at other sites.

One important aim of this report is to provide a source of information for decision-making by DOE program managers. Economically attractive options--those with the potential to save significant amounts of money while reusing or recycling existing resources-are balanced against relevant policies that some view as limiting the disposition alternatives.

Finally, the comprehensive, systematic approach and discussion is intended to be accessible to stakeholders among the general public who are participating in DOE's cleanup efforts.

\subsection{Economic Analysis Methodology-Overview}

Three alternatives for recycling and reusing Equipment in Building 865 are compared to a baseline estimate for disposal at an LLW landfill. These three alternatives are: (1) recycling, either as scrap metal or as ingots produced on-site by smelting; (2) transferring equipment for reuse at other government organizations; and (3) selling equipment to non-government organizations. The major assumptions underlying the estimates for the baseline and each of the three alternatives are briefly outlined in Table 1.1a below. As will be noted, these assumptions primarily encompass uncertainties about project duration and the decontamination process. More specific assumptions and other decision making criteria are discussed as each of the alternatives are presented in Section 2.0. 
Table 1.1a-Assumptions Underlying Cost Estimates for Baseline and Alternatives

\begin{tabular}{|c|c|}
\hline Alternatives & Major Assumptions \\
\hline $\begin{array}{l}\text { Baseline Option-Disposal at a Low } \\
\text { Level Waste Landfill }\end{array}$ & $\begin{array}{l}\text { Project Life-2 years } \\
\text { - Procurement/Contract- } \\
\text { Equipment Removal Contractor } \\
\text { - Minimal Disassembly for } \\
\text { Packaging } \\
\text { - No Decontamination }\end{array}$ \\
\hline $\begin{array}{l}\text { Recycling } \\
\text { Scrap Metal }\end{array}$ & $\begin{array}{l}\text { Project Life-2 years } \\
\text { - Decontamination Facility } \\
\text { Required (Capital and Operating) } \\
\text { - Equipment Removal Conducted } \\
\text { by a Subcontractor }\end{array}$ \\
\hline Smelted Ingots & $\begin{array}{l}\text { - Project Life-2 years } \\
\text { - Procurement of Equipment } \\
\text { Removal Contractor } \\
\text { - Minimal Disassembly for } \\
\text { Smelting } \\
\text { - On-Site Equipment Usecl for } \\
\text { Smelting to Produce Ingots } \\
\text { - Smelting Process Is Effective for } \\
\text { Decontamination } \\
\text { (DOE, August 1991) }\end{array}$ \\
\hline $\begin{array}{l}\text { Transfer for Reuse } \\
\text { Within the Government Sector }\end{array}$ & $\begin{array}{l}\text { Both Contaminated and } \\
\text { Non-Contaminated Equipment } \\
\text { May Be Considered }\end{array}$ \\
\hline $\begin{array}{l}\text { Release for Sale to } \\
\text { Non-Government Organizations }\end{array}$ & $\begin{array}{l}\text { Project Life-2 years } \\
\text { - Decontamination Facility } \\
\text { Required } \\
\text { - Public Sale In Accordance With } \\
41 \text { CFR } 101\end{array}$ \\
\hline
\end{tabular}

The cost for the baseline has been determined using Equation 1, shown in Appendix A. Each cost element of the equation was developed based on assumptions that are discussed in detail in Section 2.1 below. Two total costs are reported for the baseline option, $\$ 4,854,000.00$ and $\$ 33,130,000.00$. This first, much lower figure is based on a contractor-provided work crew of 57, a support staff of 8 , and a staff management team of 3 employed full-time over the course of two years. Disposal costs for this figure were calculated using a government rate of $\$ 10 / \mathrm{ft}^{3}$. 
The second figure is based on the same assumptions, except that a commercial disposal rate of $\$ 400 / \mathrm{ft}^{3}$ was used in an attempt to account for unpredictable costs that the government may incur, including the cost of closure, remediation, and the development of a landfill that adheres to strict construction and performance standards.

The costs for the three recycling and reuse options have been estimated using Equations 2, 3, 4, and 5 in Appendix A. These equations account for increases or decreases in the number of personnel required for each alternative. Details of the estimating process for each of the alternatives are discussed in Sections 2.2, 2.3, and 2.4. The total estimated cost for each of the three alternatives, as well as the estimates for the baseline option, appear in Table 1.1b below.

Table 1.1b Comparison of Economic Alternatives

\begin{tabular}{|c|c|c|c|c|}
\hline \multirow{2}{*}{$\begin{array}{l}\text { Alternative } \\
\text { Landfill (Baseline) }\end{array}$} & \multicolumn{2}{|c|}{ Estimated Cost } & \multicolumn{2}{|c|}{$\begin{array}{l}\text { Cost Increase } \\
\text { (or Decrease) } \\
\text { Compared to Baseline }\end{array}$} \\
\hline & $\$ 4,854,000^{1}$ & $\$ 33,130,000^{2}$ & - & \\
\hline $\begin{array}{l}\text { Recycle } \\
\text { Scrap } \\
\text { Smelt } \\
\end{array}$ & $\begin{array}{r}\$ 3,095,500^{1} \\
\$ 3,507,800^{1} \\
\end{array}$ & $\begin{array}{l}\$ 7,504,500^{2} \\
\$ 8,162,500^{2} \\
\end{array}$ & $\begin{array}{l}(\$ 1,758,500) \\
(\$ 1,346,200) \\
\end{array}$ & $\begin{array}{r}(\$ 24,967,500)^{2} \\
(\$ 24,619,500)^{2} \\
\end{array}$ \\
\hline Government Transfer & $\$ 3,026,500^{1}$ & $\$ 7,435,500^{2}$ & $(\$ 1,827,500)^{1}$ & $(\$ 25,600,500)^{2}$ \\
\hline $\begin{array}{l}\text { Unrestricted } \\
\text { Sale to the Public }\end{array}$ & $\$ 3,421,500^{1}$ & $\$ 7,830,500^{2}$ & $(\$ 1, \mathbf{4 3 2 , 5 0 0 )} 1$ & $(\$ 25,300,000) 2$ \\
\hline
\end{tabular}

1-Reflects estimated government disposal rate of $\$ 10 / \mathrm{ft}^{3}$

2-Reflects estimated commercial disposal rate of $\$ 400 / \mathrm{ft}^{3}$

Cost estimates for each of the three alternatives have been calculated for the pieces of equipment that qualify based on relevant criteria, such as potential commercial value, metal content, or need within the government sector.

Documentation of qualifying equipment for each alternative appears in Appendix B. The method of categorization was based on assigned condition codes, as well as on the suspected level of contamination and on the metal content, where applicable.

Total estimates are based on the number of personnel assumed to be required to implement each alternative for the qualifying equipment. The cost of necessary capital equipment required to complete the work has, in most cases, been prorated over 10 to 15 year periods, and the cost during the first two years has been used in calculations. This method avoids inflating the estimates with the full expense of capital equipment, such as decontamination facilities, that will be available for use after the work described in this report is complete. A description of the equipment purchases considered necessary is provided in Appendix $C$.

The total estimated cost for each of the three alternatives represents the total potential for revenue generated by the qualifying equipment or material for that 
alternative minus the cost to dispose of any remaining material as described in the baseline option. These estimates are described in detail in Section 2.0. Cost backup data for the discussions in Section $\mathbf{2 . 0}$ are provided in Appendix D.

Once a total estimated cost for each option was generated, all were compared to the cost of the baseline, landfill disposal, alternative. This simple comparison identifies the alternative with the greatest potential for cost savings. Discussions of the potential for cost savings for each alternative are also tempered to reflect state, federal, and DOE policies and other circumstances that may limit the realization of the estimated savings.

As stated, this report compares alternatives based on the rather unrealistic assumption that the selection of one of the three alternatives for disposition precludes the use of the other two. Of course, this is not the case. Maximizing the potential for cost savings or revenue generation will no doubt involve a combination of all of the options considered here. The data provided in Appendix B of this report, along with the computerized database accompanying this report, will allow more detailed planning and estimation.

The computerized, cost estimating database has been developed to allow easy modifications as assumptions are further refined. The disc provided with this report is intended for use with any DOS-based computer (version 4.0 or higher and $2 \mathrm{MB}$ of RAM). In addition, the disc includes a Foxpro Run-time Library, and therefore, the user need not $F$ urchase the FoxPro database software. Input screens allow the user to change values for the variable multipliers, such as labor rates, burial costs, and decontamination costs, while fixed values such as weight, volume, and surface area of equipment; labor estimates; equipment sales prices; and others remain constant. Simple output routines allow printing of "what-if" scenarios for data exploration, a function that will be useful in combining various alternatives to optimize the potential for cost savings and waste minimization.

\subsection{Policy Implications-Overview}

The alternatives under consideration were developed as potential options for disposition without regard to state and federal policies and procedures that may limit the viability of any alternative. Some alternatives that involve unrestricted release of equipment are controversial, and policies concerning release limits are currently under development. Section 3.0 of this report discusses the participants involved in the development of release guidelines and also presents the status of their development. The participants include DOE, the International Commission on Radiological Protection (ICRP), the International Atomic Energy Agency (IAEA), the U.S. Environmental Protection Agency (EPA), the Nuclear Regulatory Commission (NRC), the State of Colorado Department of Health, and the RFP. Figure 1.2 presents a summarized flow diagram of the surplusing process for federal equipment, and more details of the process steps appear in Appendix $E$.

Also included in section 3.1 is a sample exposure scenario for a free-release level for volumetric contamination using the proposed DOE approach. 
FIGURE 1.2 SURPLUS EQUIPMENT PROCESS FLOW DIAGRAM.

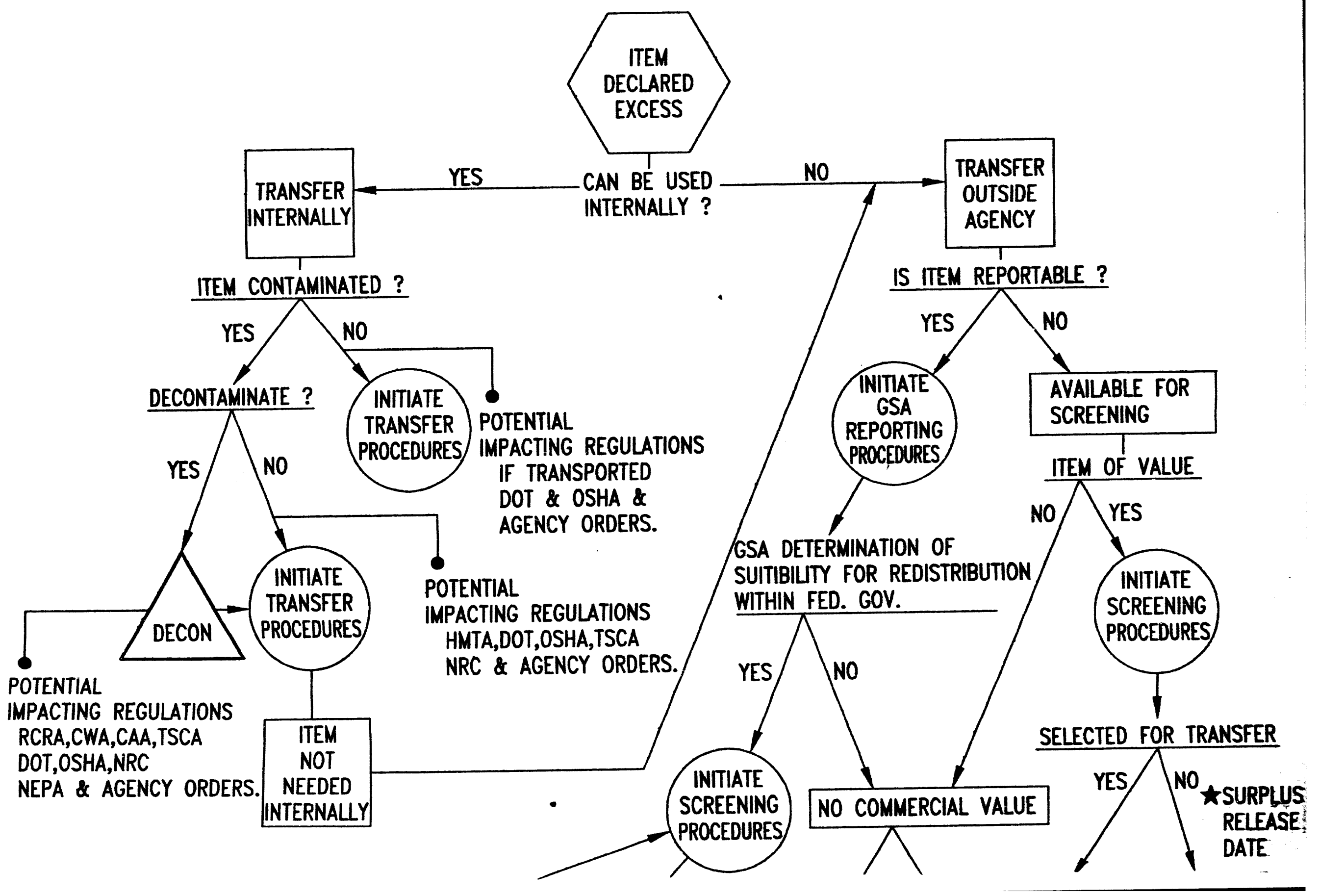




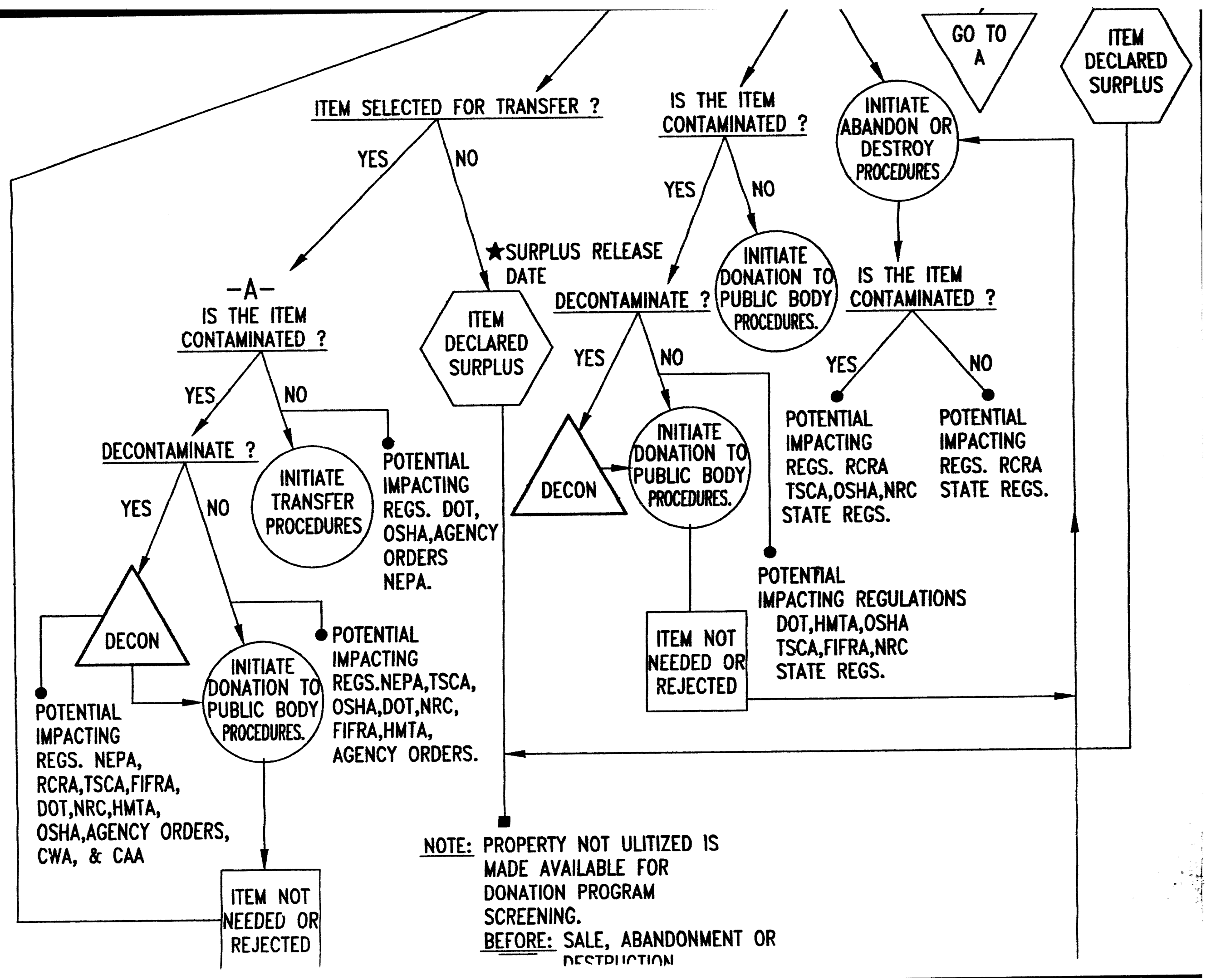




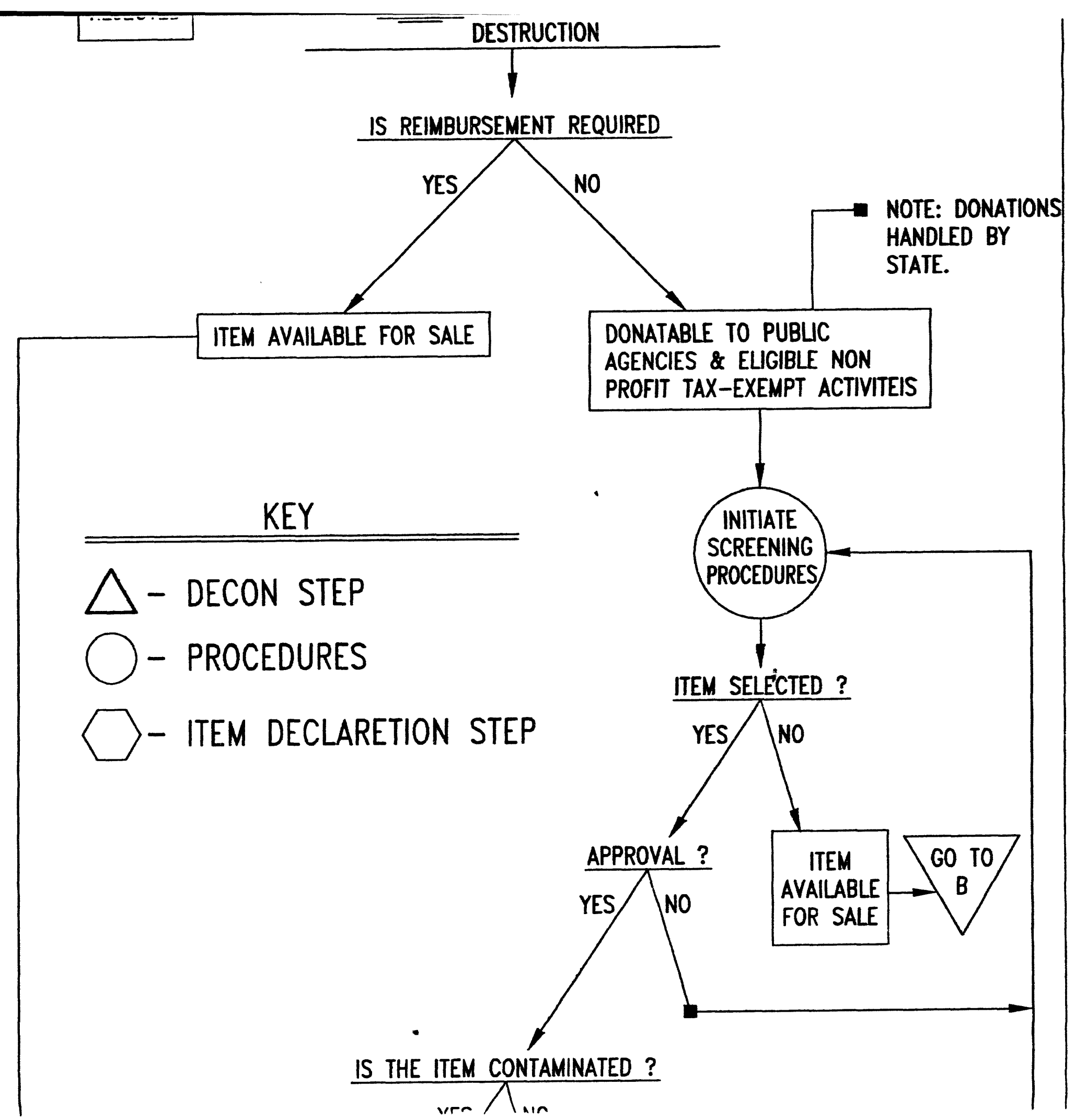




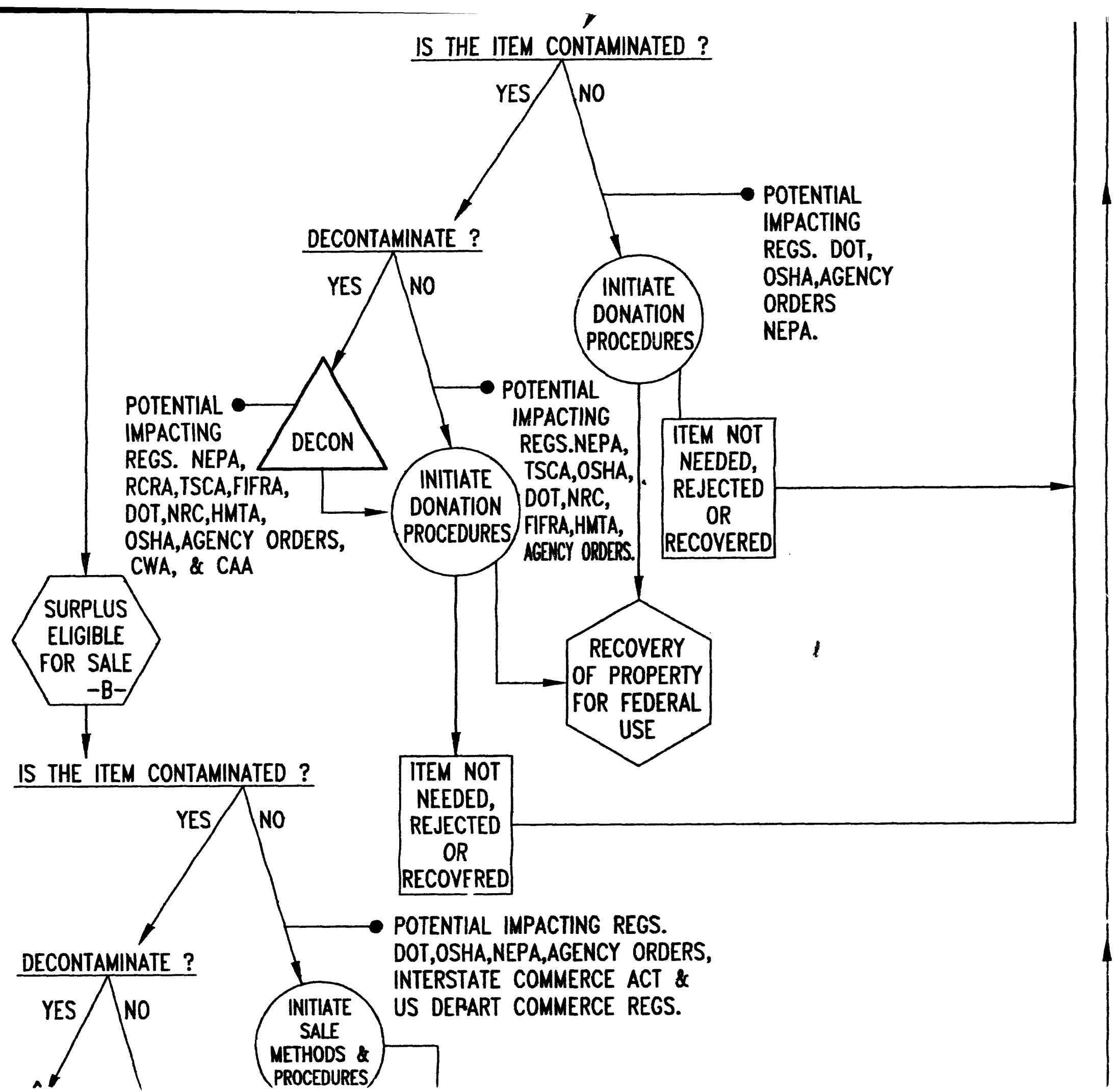




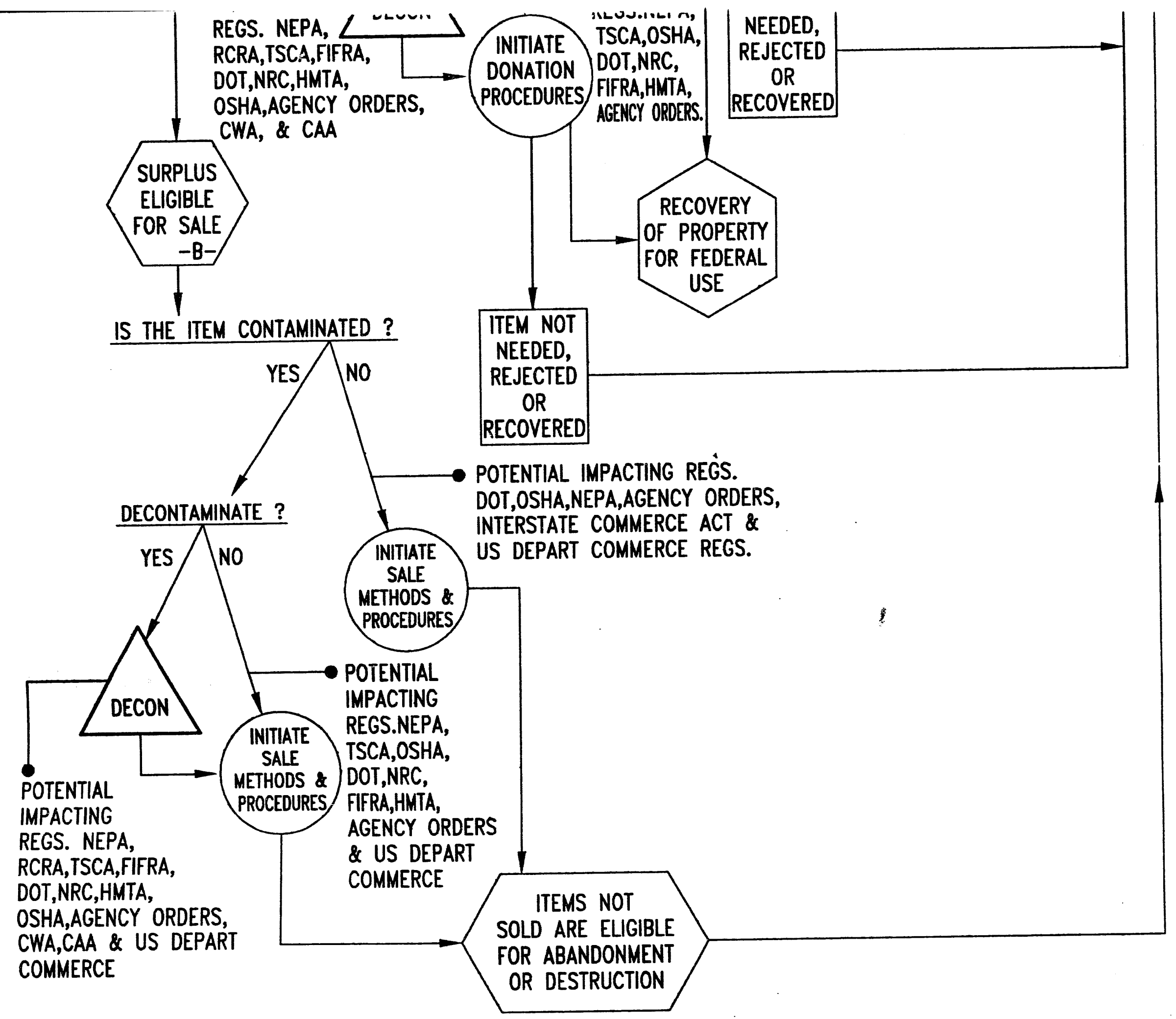




\subsection{Equipment--Overview}

As a foundation for the economic analysis, the physical condition and technological status of the equipment was evaluated. From visual inspections, a disposal condition code (as defined in 41 CFR 101-43.4801) was determined. Pieces of equipment with Federal Disposal Condition Codes of 6 or higher were considered for the disposal option only. Pieces of equipment with Federal Disposal Condition Codes of 5 or lower, or those classified " $S$ " were considered for the recycle, reuse, or release options. (See Appendix B for the assigned condition codes.)

The research and development (R\&D) mission of this facility dictated that the equipment be of small capacity for very low production and "state of the art" in application. A superlative maintenance program, coupled with very low usage, leaves the equipment in near mint condition. The proposed decontamination process promises to preserve this quality. Some of the metal forming and removal machines, manufactured in the late 1960 's, are now worth more than their original cost, because they contain large cast iron components no longer available in the United States. In fact, industrial users are routinely willing to pay more for the older cast-based machines than the newer weld-based machines that replaced them. Table 1.3 below provides an overview of equipment classes and the likely disposition routes.

Reuse of the equipment within the DOE system or within other government sectors was also explored. As a result of the DOE decision to move to a smaller, more centralized weapons complex, many DOE sites face the same situation as the RFP-an abundance of surplus equipment. Also, the many sites with an environmental restoration and waste management mission have little demand for metallurgical and process equipment.

Historically, the Department of Defense (DoD) would seem to be a likely candidate for using the equipment in government-owned, contractor-operated R\&D production facilities as well as for the maintenance of defense equipment. However, DoD currently faces the same trend in down-sizing as does DOE, and is planning the sale of a large inventory of surplus machining and metalworking equipment. 
○

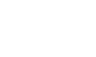

○

- 
Table 1.3 Overview of Equipment Classes and Likely Disposition

\begin{tabular}{|c|c|c|}
\hline Equipment & Potential Users & Disposition \\
\hline $\begin{array}{l}\text { Laboratory Equipment. } \\
\text { State-of-the-art } \\
\text { metallurgical laboratory } \\
\text { equipment used for } \\
\text { characterizing metal samples } \\
\text { (hardness, grain structure, } \\
\text { tensile strength, surface } \\
\text { finish, etc.) and the } \\
\text { preparation of samples. This } \\
\text { equipment is new (acquisition } \\
\text { dates mostly 1990-1992) and } \\
\text { the instruments calibrated } \\
\text { and certified. }\end{array}$ & $\begin{array}{l}\text { Metallurgical labs, physics } \\
\text { labs, and R\&D facilities. } \\
\text { Items } 1 \text { through } 32 \text { will be of } \\
\text { particular interest to } \\
\text { virtually all colleges and } \\
\text { universities. }\end{array}$ & $\begin{array}{l}\text { Practically all pieces of this } \\
\text { equipment are candidates for } \\
\text { disposition at some step in } \\
\text { the Surplusing Process } \\
\text { including, transfer, donation } \\
\text { or sale. }\end{array}$ \\
\hline $\begin{array}{l}\text { Machining. } \\
\text { Lathes, milling machines, } \\
\text { drill presses, grinders, etc. } \\
\text { These are standard machine } \\
\text { tools with manual controls } \\
\text { (except item } 51 \text {, Series II } \\
\text { Bridegport-DNC Control) } \\
\text { with acquisition dates } \\
\text { ranging from } 1968 \text { to } 1991 . \\
\text { With the exception of the } 64 " \\
\text { VTL, all are small tool room } \\
\text { class machines with superior } \\
\text { accuracies normally } \\
\text { associated with that class of } \\
\text { machine tolls. The } 64 " \text { VTL is } \\
\text { a mid-sized VTL originally } \\
\text { built in the late } 60 \text { 's and } \\
\text { transferred to RFP in } 1991 . \\
\text { All these machines are in } \\
\text { excellent condition and carry } \\
\text { a Federal Disposal Condition } \\
\text { Code of } 4 \text { with a few } 5 \text { 's. } \\
\text { Includes equipment list items } \\
35 \text { through } 72,97 \text { and } 98 \text {. }\end{array}$ & $\begin{array}{l}\text { R\&D facilities, job shops, } \\
\text { DOE and other federal } \\
\text { agencies bent on upgrading } \\
\text { machine tool inventories, and } \\
\text { educational institutions, } \\
\text { particularly those with } \\
\text { Vocational Training } \\
\text { Programs. }\end{array}$ & $\begin{array}{l}\text { Almost all pieces of the } \\
\text { equipment are candidates for } \\
\text { disposition at some step in } \\
\text { the Surplusing Process, } \\
\text { including recycling, transfer } \\
\text { and sale. In fact, much of this } \\
\text { equipment will find an } \\
\text { aggressive commercial } \\
\text { market. }\end{array}$ \\
\hline
\end{tabular}




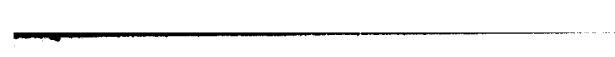

.

$\bullet$ 
Table 1.3 (continued)

Overview of Equipment Classes and Likely Disposition

\begin{tabular}{|c|c|c|}
\hline Equipment & Potential Users & Disposition \\
\hline $\begin{array}{l}\text { Metal Cutting } \\
\text { Band saws, cut off saws and } \\
\text { shears. These are standard } \\
\text { metal cutting machines with } \\
\text { small to medium capacities } \\
\text { with acquisition dates } \\
\text { ranging from } 1969 \text { to } 1992 \text { (all } \\
\text { but items } 34,62,118 \text { and } 119 \\
\text { are } 1991 \text { and } 1992 \\
\text { acquisitions). All equipment } \\
\text { is in excellent condition and } \\
\text { carries Federal Disposal } \\
\text { Condition Codes of } 4 \text { and } 5 \text {. } \\
\text { Includes equipment list items } \\
34,41,45,62,86,94,117,118 \text {, } \\
119,140 \text { and } 141 \text {. }\end{array}$ & $\begin{array}{l}\text { R\&D facilities, job shops, } \\
\text { DOE and other federal } \\
\text { agencies bent on upgrading } \\
\text { machine tool inventories, and } \\
\text { educational institutions, } \\
\text { particularly those with } \\
\text { Vocational Training } \\
\text { Programs. }\end{array}$ & $\begin{array}{l}\text { Almost all pieces of the } \\
\text { equipment are candidates for } \\
\text { disposition at some step in } \\
\text { the Surplusing Process, } \\
\text { including recycling, transfer } \\
\text { and sale. In fact, much of this } \\
\text { equipment will find an } \\
\text { aggressive commercial } \\
\text { market. }\end{array}$ \\
\hline $\begin{array}{l}\text { Metal Forming. } \\
\text { Drai benches, roll formers, } \\
\text { rolling mills, hydro formers, } \\
\text { swagers, and forging forming } \\
\text { and extrusion and isostatic } \\
\text { presses. These are standard } \\
\text { commercial machines with } \\
\text { small to medium capacities. } \\
\text { All are in excellent condition } \\
\text { with Federal Disposal } \\
\text { Condition Codes of } 4 \text { and } 5 \text {. } \\
\text { Acquisition-1968 to } 1992 \text {. }\end{array}$ & $\begin{array}{l}\text { R\&D facilities, and job shops: } \\
\text { - Production of small batches } \\
\text { of thin wall shapes (121, } \\
\text { hydrospin and 148, 150-ton } \\
\text { press). Re-rolling alloy } \\
\text { strip (135 and 136) strip and } \\
\text { foil rolling mills, alloy } \\
\text { billet rolling, hot or cold, } \\
\text { (137, 24" rolling mill), hot } \\
\text { and cold extrusion (2000-ton } \\
\text { extrusion press). } \\
\text { - Conventional forging (144, } \\
5000 \text {-pound forging hammer } \\
\text { and } 145 \text { and } 146, \text { swagers). } \\
\text { - Hydraulic and high } \\
\text { pressure tubing production } \\
\text { (96, draw bench and } 145 \text { and } \\
146, \text { swagers). } \\
\text { - Compaction/molding of } \\
\text { metal (or ceramic) powder } \\
\text { (120 and 158, isostatic } \\
\text { presses). }\end{array}$ & $\begin{array}{l}\text { Almost all pieces of the } \\
\text { equipment are candidates for } \\
\text { disposition at some step in } \\
\text { the Surplusing Process, } \\
\text { including recycling, transfer } \\
\text { and sale. In fact, as much as } \\
\text { half of the equipment in this } \\
\text { category has potential to be } \\
\text { offered for public sale. }\end{array}$ \\
\hline
\end{tabular}


•

$\bullet$

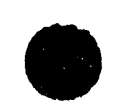


Table 1.3 (continued)

Overview of Equipment Classes and Likely Disposition

\begin{tabular}{|c|c|c|}
\hline Equipment & Potential Users & Disposition \\
\hline $\begin{array}{l}\text { Heat Treating } \\
\text { Furnaces and their } \\
\text { auxiliaries for heat treating } \\
\text { (annealing and solution } \\
\text { hardening) pyrophoric } \\
\text { and/or air corroding metals. } \\
\text { Atmospheres include } \\
\text { nitrogen, argon, and helium } \\
\text { (no helium) and full vacuum. } \\
\text { Temperature range from } 1200 \\
\text { to } 1600 \text { C. Resistance and } \\
\text { induction size range from } 6 " \\
\text { diameter } \times 6 " \text { long to } 60 " \\
\text { diameter } \times 50^{\prime \prime} \text { long heated } \\
\text { chamber, vertical and } \\
\text { horizontal loading } \\
\text { configurations. These are } \\
\text { state-of-the-art heat } \\
\text { treating units with small to } \\
\text { medium capacities and very } \\
\text { high temperatures. They are } \\
\text { in excellent condition with } \\
\text { Federal Disposal Condition } \\
\text { Codes of } 4 \text { and } 5 \text { and } \\
\text { procurement dates ranging } \\
\text { from } 1970 \text { to } 1992 \text {. }\end{array}$ & $\begin{array}{l}\text { R\&D facilities, specialty } \\
\text { heat treaters, particularly } \\
\text { those involved with high } \\
\text { temperature metals and their } \\
\text { alloys. The physical size and } \\
\text { minimal environmental } \\
\text { impact would make them } \\
\text { equally at home in a } \\
\text { laboratory or industrial } \\
\text { setting. Specifically these } \\
\text { are items } 93,108 \text { through } 113, \\
\text { and } 149 .\end{array}$ & $\begin{array}{l}\text { Almost all of the pieces of } \\
\text { equipment are candidates for } \\
\text { disposition at some step in } \\
\text { the Surplusing Process, } \\
\text { including recycling, transfer } \\
\text { and sale. In fact, many will } \\
\text { find a very receptive } \\
\text { industrial market. }\end{array}$ \\
\hline $\begin{array}{l}\text { Metal Melting. } \\
\text { Items } 99-\text { Electron Beam } \\
\text { Furnace and 15-Vacuum } \\
\text { Induction Furnace. The units } \\
\text { were acquired in } 1970 \text { and } \\
1990 \text { respectively and both } \\
\text { carry a Federal Disposal } \\
\text { Condition Code of 4. These } \\
\text { are state-of-the-art } \\
\text { laboratory size units for } \\
\text { melting and casting high } \\
\text { purity, high temperature } \\
\text { metals. }\end{array}$ & $\begin{array}{l}\text { R\&D facilities and any } \\
\text { laboratory engaged in basic } \\
\text { metallurgical research. }\end{array}$ & $\begin{array}{l}\text { Candidates for disposition at } \\
\text { some step in the Surplusing } \\
\text { Process, most probably } \\
\text { transfer or sale. }\end{array}$ \\
\hline
\end{tabular}





\subsection{Economic Analysis of Altematives for Disposition}

This section describes the four disposition alternatives under consideration, including details of the activities considered necessary to conduct work under each alternative. Further details supporting the cost estimates are provided in Appendix D.

The economic analysis depends on the development of credible cost estimates. Therefore, each option was broken down into the activities that are expected to be required, and estimates were made for the various operating, management and capital costs associated with each activity. All cost estimates are fully documented to allow future refinements. The cost estimates were developed to the level of detail commonly used at the conceptual design phase of engineering projects. In addition, the equations for calculating each estimate, presented in Appendix A, have been computerized to allow easy incorporation of future changes or refinements.

To evaluate the potential increase or decrease in the cost of implementing each of the three alternatives compared to the baseline, estimated costs and revenues have been calculated for the pieces of equipment that qualify for an alternative based on relevant criteria, such as metal value, potential demand in the government sector, or commercial value. Documentation of qualifying equipment for each alternative appears in Appendix B. The method of categorization was based on assigned condition codes, as well as on the suspected level of contamination and on the metal content, where applicable. In each alternative, the equipment that does not qualify is disposed of as described in Section 2.1 below, and costs estimated accordingly for inclusion in the grand total estimated cost for the option.

\subsection{Baseline Alternative-Landfill Disposal}

The baseline alternative, burial of Building 865 equipment, represents the "worst case scenario" from an economic standpoint. That is, for the purposes of this estimate, all equipment is assumed to have no economic worth. Furthermore, it is assumed for this option that the cost of decontamination, and subsequent sampling and surveying to verify decontamination, is prohibitive. In such cases, the procedures outlined in 10 CFR 101-45.9, Abandonment or Destruction of Personal Property; 48 CFR 45.603, Disposal Methods; 48 CFR 45.611, Destruction or Abandonment; and 48 CFR 45.613, Property Disposal Determination, would be invoked to classify the equipment as waste for disposal in an approved LLW landfill.

- The total estimated cost for this option reflects the assumption that all Building 865 equipment would be removed directly to a LLW landfill.

\subsubsection{Assumptions Underlying the Landfill Disposal Alternative}

The following major assumptions were used to develop the cost estimate for the baseline option:

- 2-year project life

- Equipment disassembly, removal, and packaging conducted by a subcontractor

- Disassembly and/or volume reduction includes only the minimum for 
packaging

- Packaging in $20^{\prime} \times 8^{\prime} \times 8^{\prime}$ sealand containers with a 40,000 lb. weight limit (U.S. Department of Transportation (DOT) regulation)

- No decontamination

- The waste is classified as a mixed waste (U-238 and beryllium contamination)

- Management and compliance activities will be conducted by a DOE-RFP Management and Operating (M\&O) contractor staff

- Removal of all fluids from equipment

- Drained oils, coolants, and lubricants are Toxic Substance Control Act (TSCA) regulated waste only

\subsubsection{Elements of the Landfill Disposal Cost Analysis}

Figure 2.1 shows a schematic of the elements used in developing a comprehensive estimate of the cost of disposing of the Building 865 equipment. Appropriate cost categories, including operations, management, regulatory compliance, transportation, and disposal were included for each element. A brief description of the cost elements is provided below.

2.1.2.1 - Cost of Removal and Disposal of Hydraulic and Coolant Oils

Before disposal, the coolant and lubricant fluids will be drained and the reservoirs flushed with cleaning solvents. The likelihood of fluids containing PCBs is high for equipment that was in service during the early 1970s, as DOE, then the Atomic Energy Commission (AEC) promoted the use of PCB-laden fluids as a part of an agency-wide fire protection program. Cost estimates were based on disposal (incineration) of the drained fluids plus two reservoir volumes of cleaning solvents to flush any residual PCBs and ensure compliance with the TSCA limits for PCB contamination. Costs for labor to drain, flush, and package have been estimated, as well as costs for transportation, disposal, and materials. The following calculation was developed to determine a cost for each item in this category. This estimate of disposal costs is for TSCA wastes only. Note that the estimated average labor cost per item for this step is $\$ 200$.

Per Item Cost $=\$ 200+\$ 34.15 *$ (gallons to be disposed).

Costs for disposal of TSCA/LLW wastes are considerably higher, and should be estimated according to the following equation:

Per Item Cost $=\$ 200+\$ 115.15 *$ (gallons to be disposed). 


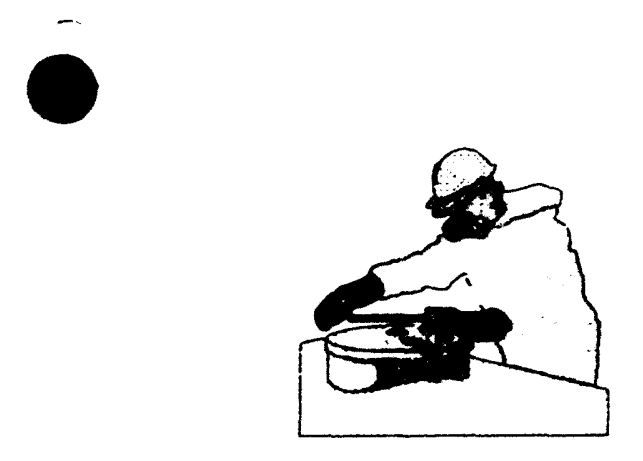

Cost of Removal and Disposal of Hydraulic and Coolant Oils

$\vec{\sigma}$

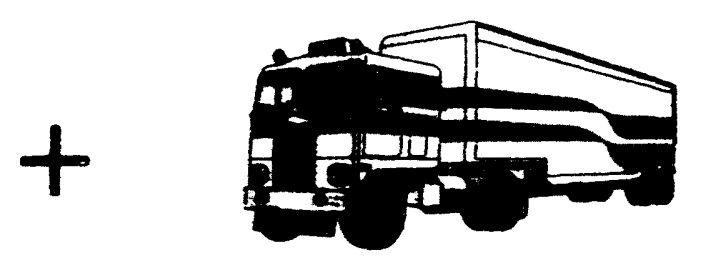

Cost of Shipping Containers and Transportation

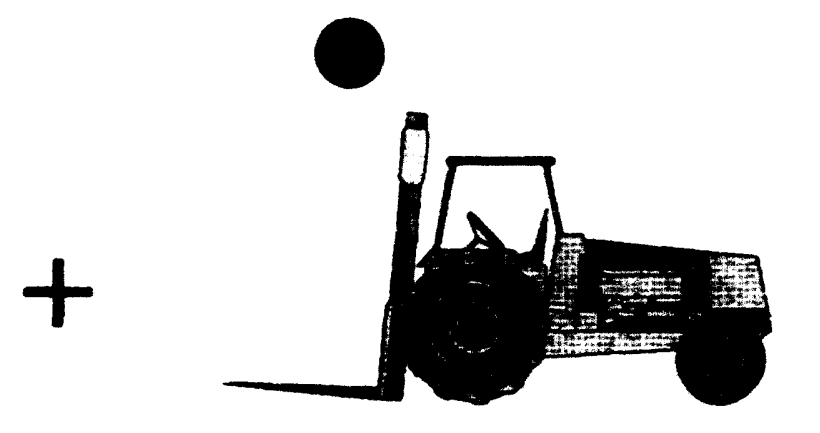

Cost of Labor and Equipment for Disassembly and Removal to a Staging Area
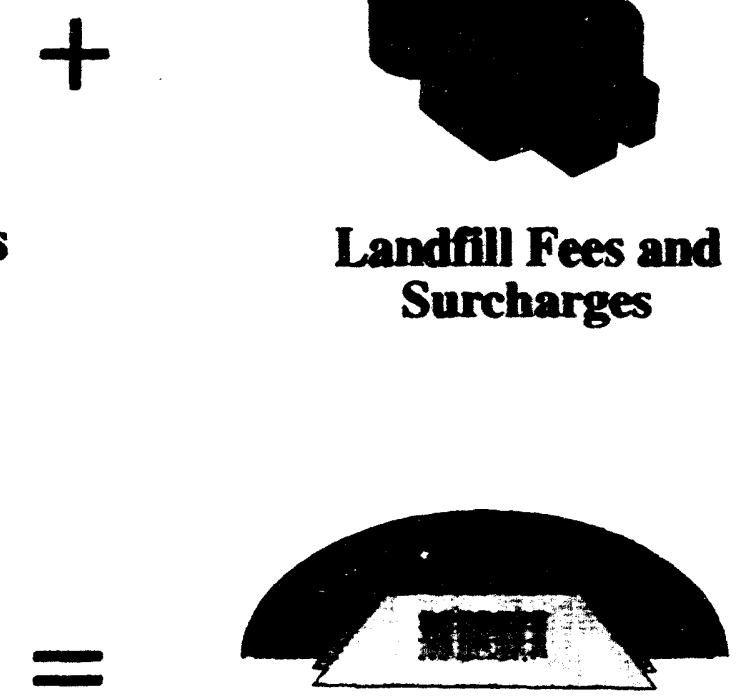

Cost of Landfill Disposal
$+$

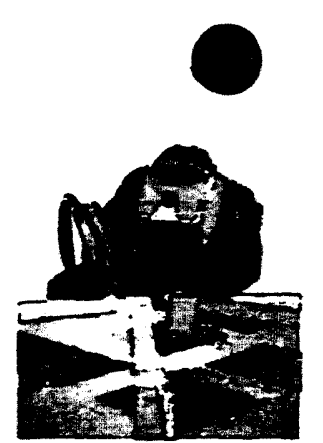

Cost of Additional Disassembly, Cutting, and/or Shredding Necessary for Packaging

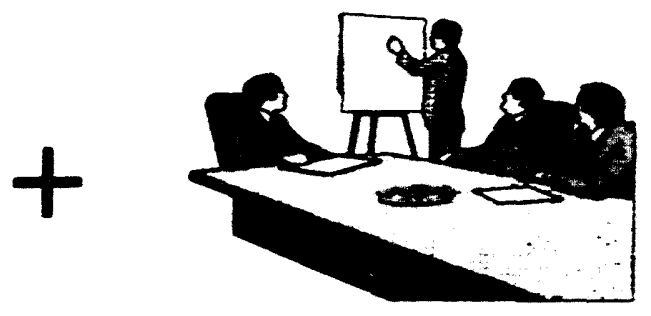

Cost of Management and Regulatory Compliance

Figure 2.1

Cost Elements for Baseline Alternative - Landfill Disposal 


\subsubsection{2- Cost of Labor and Equipment for}

Disassembly and Removal to a Staging Area

The disassembly of equipment and removal of components to a staging area will be conducted by a fixed-price subcontractor. The cost for equipment disassembly and removal was developed by assuming that work crews would be variably comprised, designed to include persons with the minimum skills required to work with particular types of equipment (such as milling machines, furnaces, extrusion presses, etc.). Once appropriately qualified crews were defined for particular types of equipment, the time required for the disassembly and removal of individual pieces of equipment was estimated. Costs for this element include only the resources and equipment required to disassemble the equipment and remove components to a staging area. Cost varied greatly depending on equipment size and complexity, ranging from $<\$ 200.00$ per piece to $\$ 66,000$ per piece.

\subsubsection{3-Cost of Additional Disassembly, Cutting, and/or Shredding} Necessary for Packaging

Any additional volume reduction necessary for packaging will be conducted by a fixed-price subcontractor. As discussed in the disassembly element above, appropriately qualified crews were defined for the various classes of equipment likely to require this additional step. Final labor estimates were based on the amount of time required to disassemble each of these pieces of equipment for packaging. Only the minimum reduction in volume for packaging was used to formulate this estimate. Packaging in compliance with DOT regulations was considered.

\subsubsection{4-Cost of Shipping Containers and Transportation}

It was assumed that sealand containers would be used for disposal, as their use on large jobs reduces handling costs. When using these relatively large containers, a major constraint will be the weight limit. Much of the equipment is constructed of dense material, and will fill only a fraction of the volume of these containers when, in fact, the weight limit of the container has been reached. Cost estimates are based on the total number of partially filled (volume) sealand containers that will be required to accommodate the estimated weight of equipment to be disposed. Additional costs for blocking to limit the likelihood of shifting loads within the containers was included. These costs are estimated to average $\$ 7,550$ per sealand container.

\subsubsection{5-Landfill Fees and Surcharges}

Cost estimates were developed for burial of LLW at both current government facilities and commercial facilities. Current government cost does not reflect the added cost of operating a LLW landfill within the regulatory framework. Commercial rates do reflect these costs and include items such as public involvement, design and construction of facilities that meet or exceed current design criteria, and state imposed surcharges. Using the commercial rate provides a potential future cost to the DOE for burial, either for using commercial facilities or for operational changes at DOE facilities. 
DOE burial rates ranged from $\$ 10 / \mathrm{ft}^{3}$ at the Nevada Test Site (NTS) to approximately $\$ 60 / \mathrm{ft}^{3}$ at Hanford. Commercial rates ranged from $\$ 300$ to $\$ 500 / \mathrm{ft}^{3}$ depending on the site. An international cost comparison of nuclear waste disposal (Vira, 1992) reported the disposal price for the U.S. between $\$ 100$ and $\$ 600 / \mathrm{ft}^{3}$, depending on the type of waste. For this study, the government disposal rate used was $\$ 10 / \mathrm{ft}^{3}$ and the commercial rate used was $\$ 400 / \mathrm{ft}^{3}$. Total burial costs for one sealand container are estimated at $\$ 12,800$ using the current government rate and $\$ 512,000$ using the estimated commercial rate.

\subsubsection{6- Cost of Management and Regulatory Compliance}

Cost estimates for regulatory and management activities include planning and management of the various activities conducted by both subcontractor and M\&O staff. These include equipment removal, waste packing, and health and safety surveillance. In addition to regular management, a staff will be needed to develop waste management plans, complete the necessary documentation to meet waste acceptance criteria, adhere to regulatory compliance activities to declare equipment and scrap as waste, manifest waste shipments, and correspond to state and federal regulatory agencies. Estimates for the staff requirements to conduct these activities for the landfill disposal option were developed and include the following:

1 Program Manager

2 Project Managers

6 Regulatory Compliance Support Staff

2 Administrative Support Staff

\subsubsection{Summary of the Land Disposal Cost Estimate}

The estimated costs for the baseline alternative are summarized in Table 2.1 below. Approximately 57 sealand containers are estimated to require disposal under this alternative. Two totals are provided to reflect the potential cost to government for landfill fees. The first total reflects the current government rate of $\$ 10 / \mathrm{ft}^{3}$. This rate is being re-evaluated by the NTS and is likely to increase for FY '94. The second total is more reflective of the real cost to the government, which will include elements such as future changes in closure and remediation regulations. 
Table 2.1 Cost Summary for Baseline Alternative

\begin{tabular}{|l|c|}
\hline Cost Element & Cost Estimate for the Element \\
\hline $\begin{array}{l}\text { Cost of Removal and Disposal } \\
\text { of Hydraulic and Coolant Oils }\end{array}$ & $\$ 173,000.00$ \\
\hline $\begin{array}{l}\text { Cost of Labor and Equipment for } \\
\text { Disassembly and Removal } \\
\text { to a Staging Area }\end{array}$ & $\$ 538,000.00$ \\
\hline $\begin{array}{l}\text { Cost of Additional Disassembly, } \\
\text { Cutting, and/or Shredding } \\
\text { Necessary for Packaging }\end{array}$ & $\$ 222,000.00$ \\
\hline $\begin{array}{l}\text { Cost of Shipping Containers } \\
\text { and Transportation }\end{array}$ & $\$ 433,000.00$ \\
\hline Landfill Fees and Surcharges & $\$ 2,764,000.000$ \\
\hline $\begin{array}{l}\text { Cost of Management } \\
\text { and Regulatory Compliance }\end{array}$ & \multicolumn{1}{|c|}{ Grand Totals } \\
\hline
\end{tabular}

1-Reflects estimated government disposal rate of $\$ 10 / \mathrm{ft}^{3}$.

2-Reflects estimated commercial disposal rate of $\$ 400 / \mathrm{ft}^{3}$.

This option is considered the "worst case scenario" from an economic standpoint, and it is also the least desirable when considering the waste minimization hierarchy established by the National Pollution Prevention Act of 1990. This act stipulates that a landfill option should only be pursued after all other options are found to be impractical.

Estimates developed in the following sections will be compared to the baseline totals in Table 2.1 and summarized in Section 2.5 . 
.

0

○ 


\subsection{Metal Recycling}

In recent years, changes in the regulatory and political climate have increased the awareness of potential impacts to the environment from waste treatment, storage, and disposal. Both regulators and management have begun to develop and implement waste minimization plans that reduce or eliminate the generation of wastes. In an effort to estimate the economic impacts of such waste minimization efforts for the D\&D of Building 865 equipment, estimates have been developed for two recycling alternatives, namely, segregating and decontaminating metals as scrap, and smelting metals to produce ingots for future use.

Note that these cost analyses account only for the estimated value of the scrap or the ingots as raw materials. Neither further refinements of the scrap, nor further uses of the ingots (for applications such a constructing shielding or LLW boxes) are proposed here. An economic evaluation of the best alternatives for final use of scrap or of ingots is beyond the scope of this report.

The following section outlines the approach used to develop cost estimates for these two alternatives.

\subsubsection{Assumptions Underlying the Metal Recycling Alternatives}

The economic analysis of metal recycling alternatives includes consideration of two possible plans for recycling the metal content of the equipment. These two (2) scenarios are:

Recycle Scenario 1

Recycle as scrap metal-segregate and decontaminate Assumptions:

- Decontamination facilities required

- Disassembly includes only the minimum required for decontamination

Recycle Scenario 2

Recycle as ingots-smelt to decontaminate Assumptions:

- Disassembly includes only the minimum required for smelting

- Use of on-site equipment (including smelter) to perform work

- The alternative involves the production of an ingot

- Smelting process is effective for decontamination (DOE, August 1991)

In addition to these scenario-specific recycle assumptions, the following are the major assumptions used to develop the cost estimates for both methods of recycling the metal:

- 2-year project life

- Equipment disassembly conducted by a subcontractor

- Management and compliance activities will be conducted by a DOE-RFP M\&O contractor staff

- Removal of all fluids from equipment

- Drained oils, coolants, and lubricants are TSCA regulated waste only 


\subsubsection{Elements of the Metal Recycling Cost Analysis}

Figures $2.2 \mathrm{a}$ and $2.2 \mathrm{~b}$ show schematics of the elements used in developing a comprehensive estimate of the cost of disposition of the Building 865 equipment by disassembling and either recycling as scrap metal or recycling as smelted metal. Appropriate cost categories, including operations, management, regulatory compliance, transportation, and disposal were included for each element. A brief description of the cost elements is provided below.

\subsubsection{1-Cost of Removal and Disposal of Hydraulic and Coolant Oils}

See Section 2.1.2.1 for a discussion of this cost element.

\subsubsection{2- Cost of Labor and Equipment for}

Disassembly and Removal to a Staging Area

The disassembly of equipment and removal of components to a staging area for both decontamination and smelting will be conducted as described in Section 2.1.2.2 earlier in this report.

\subsubsection{3 - Cost of Additional Disassembly and Segregation}

to Prepare for Decontamination or Smelting

In addition to disassembly, smelting requires segregating of metals and the further reduction of the components to a size that can be accommodated by the charging opening of the smelter. The smelter is assumed to be an arc furnace with a 3000-pound ingot mold and a 3-inch diameter charging opening. The merals selected for smelting will be limited to cast iron and steel. The non-ferrous metal content of the equipment is considered to be negligible.

Similarly, decontamination requires segregation of metals and reduction of the components to a suitable size. Although it is possible to decontaminate larger pieces than can be accommodated by the smelting operation, the cost estimates for disassembly in this step are based on the size limitations of the smelting operation. The metals selected for decontamination will be limited to cast iron and steel.

This additional volume reduction necessary for either decontamination or smelting will be conducted by a fixed-price subcontractor. As discussed in the disassembly element above, appropriately qualified crews were defined for the various classes of equipment likely to require this additional step. Final labor estimates were based on the amount of time required to disassemble each of these pieces of equipment for either decontamination or smelting. 


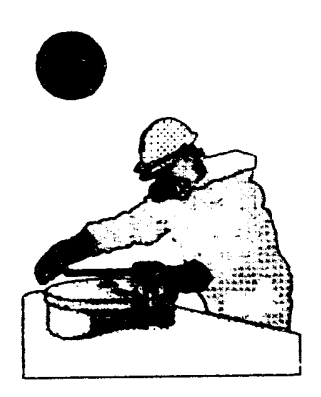

Cost of Removal and Disposal of Hydraulic and Coolant Oils

\section{$+$}

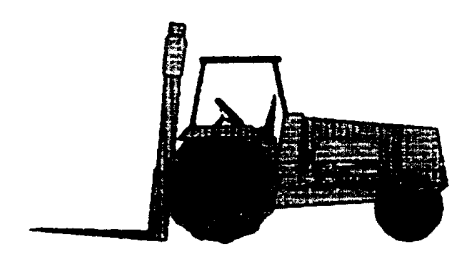

$$
\begin{aligned}
& \text { Cost of Labor and } \\
& \text { Equipment for } \\
& \text { Disassembly and } \\
& \text { Removal to a Staging } \\
& \text { Area }
\end{aligned}
$$

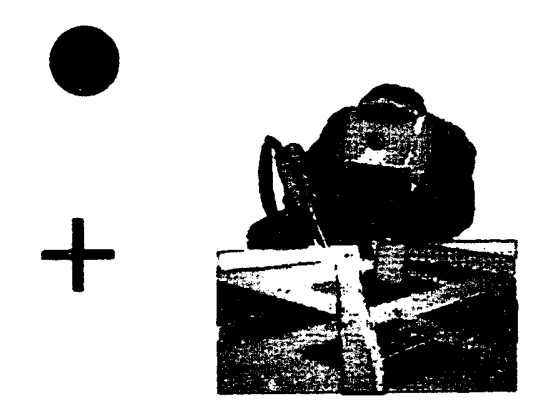

Cost of Additional

Disassembly and

Segregation to

Prepare for

Decontamination

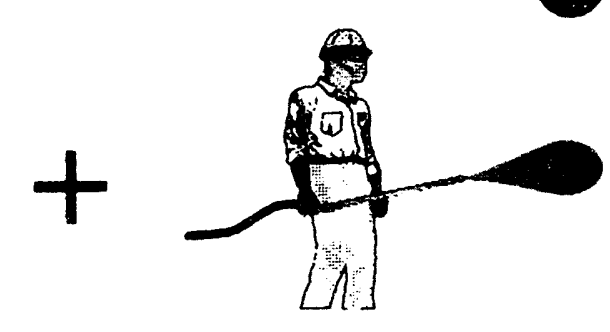

Cost of Decontamination of Scrap Metal for

Unrestricted

Release

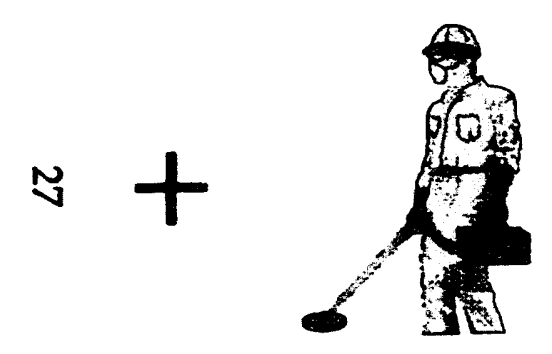

Cost of Sampling and Survey

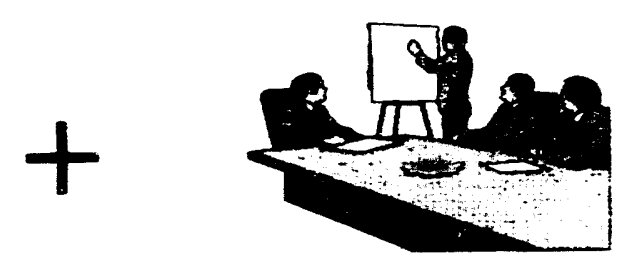

Cost of Management and Regulatory Compliance

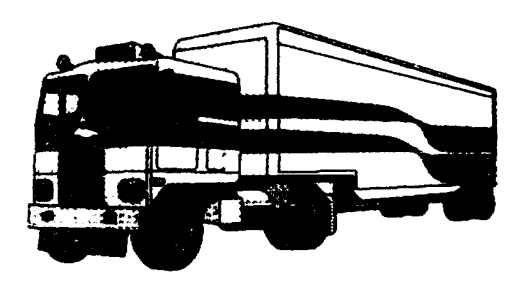

Cost of Shipping Containers and Transportation

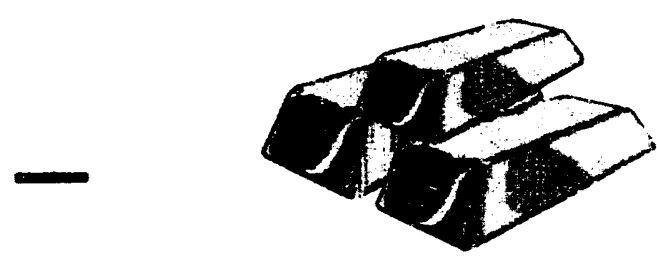

Metal Value
1

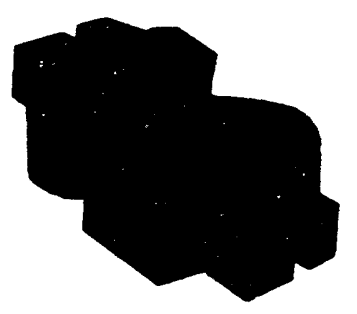

Landfill Fees and Surcharges

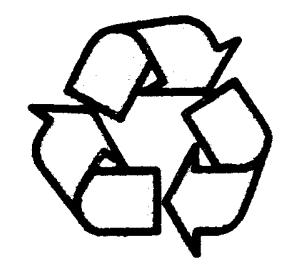

Cost of Recycling Scrap

Figure 2.2a 


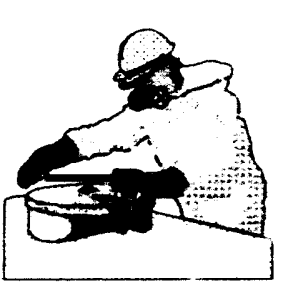

Cost of Removal and Disposal of Hydraulic and Coolant Oils

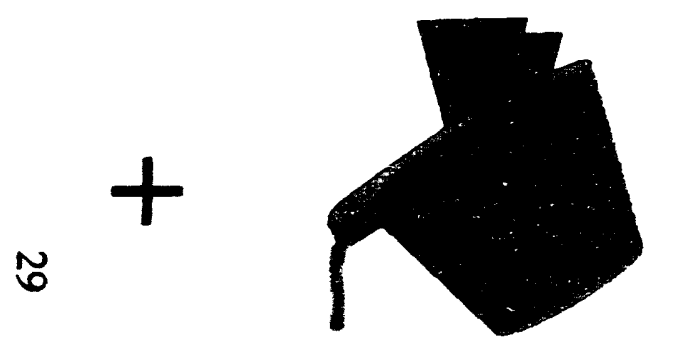

. Cost of Smelting

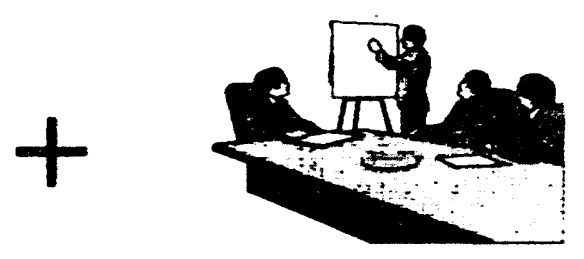

Cost of Management and Regulatory Compliance

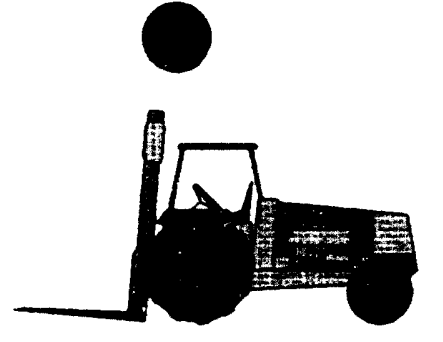

Cost of Labor and Equipment for Disassembly and Removal to a<smiles>C[Si](C)(C)C</smiles>

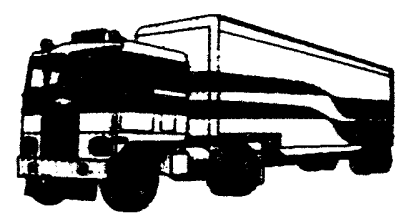

Cost of Shipping Containers and Transportation

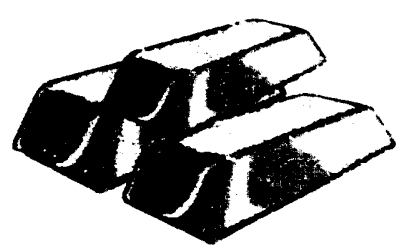
Staging Area

Metal Value
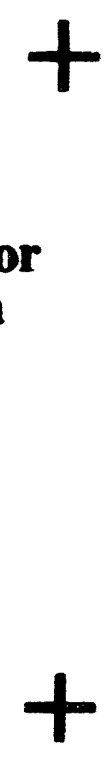

Figure 2.2b

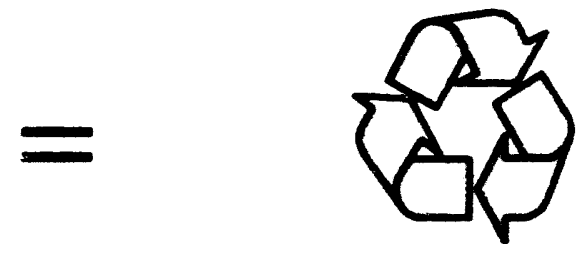

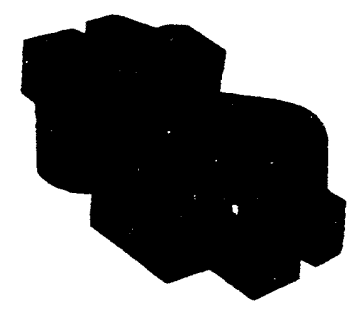

Landfill Fees and Surcharges

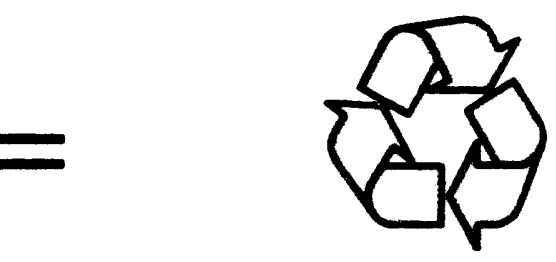

Cost of Recycling - Smelting

Cost of Additional Disassembly and Segregation to Prepare for Smelting

Cost Elements for Metal Recycling - Smelting 
-

-

- 
2.2.2.4-Cost of Decontamination of Scrap Metal for Unrestricted Release

The cost for decontamination was developed by first assuming that work crews would be variably comprised, designed to include persons capable of conducting the level of decontamination necessary to meet the regulatory standards for unrestricted release. Also considered in the estimate was the amount of time necessary to decontaminate each piece of metal to the level necessary to meet the regulatory standards for unrestricted release.

It was assumed that decontamination waste are mixed wastes. The costs for packaging, transport, disposal and material were estimated. Disposal cost for materials are for mixed waste. Landfill fees and surcharges for waste generated during decontamination were included. Waste generated from decontamination efforts consist of HEPA filters which will be compacted into drums.

Cost estimates for decontaminating the segregated bulk metals were developed by adjusting the decontamination costs developed for both the equipment reuse and the free-release alternatives discussed in Section 2.3.2.4 and 2.4.2.4. These adjustments include no allowances for repainting and an increase in the cost per square foot of surface area to account for the additional decontamination resulting from additional disassembly and volume reduction.

Although maintaining the integrity of the equipment is not an issue for this recycling alternative, as it is for both reuse and free-release, consideration of waste minimization concepts leads to the selection of the $\mathrm{CO}_{2}$ method as the preferred decontamination method for recycling as well. The cost estimates are based on the assumption that removal of all paint will decontaminate metals to levels satisfying free-release criteria. The estimated cost of decontamination of scrap metal is $\$ 24 / \mathrm{ft}^{2}$.

The assumption used as an end point for decontamination is the removal of all paint. Estimates of the amount of surface area to be cleaned were based on an envelope area that totally enclosed the equipment. Although the surface area to be decontaminated under this option will undoubtedly be greater than for either the transfer or sale options, this likely increase is accounted for in the development of a higher cost estimate for decontamination per square foot. Cost backup is provided in Appendix D.

\subsubsection{5-Cost of Sampling and Survey}

The cost for sampling and survey was developed by assuming appropriately qualified crews needed to manually survey and sample the decontaminated scrap metal. Estimates of the amount of survey and sampling required are based on the level of decontamination required for unrestricted release. Once the crews were defined, the time required for the survey and sampling of the metal was estimated. Cost backup is provided in Appendix D.

\subsubsection{6-Cost of Smelting}

Existing equipment at RFP will be used for smelting operations. The estimated per-pound cost of smelting presented here includes labor and electricity costs. The costs for smelting cast iron and steel were estimated to be $\$ 1.15 / \mathrm{lb}$. and $\$ 1.25 / \mathrm{lb}$., respectively. These costs reflect the charge by commercial metal processors. 


\subsubsection{7-Cost of Shipping Containers and Transportation}

Materials not suitable for smelting or for processing as scrap, such as electrical and nonmetallic components, will be disposed as LLW. In addition, equipment with a disposal condition of " $S$ " will be disposed as LLW based on its potential level of contamination and low metal content. It was assumed that sealand containers would be used for disposal of equipment that is not suitable for recycling, as described in Section 2.1.2.4.

\subsubsection{8 - Landfill Fees and Surcharges}

Cost estimates were developed for burial of sealand containers at both current government facilities and commercial LLW facilities, as described in Section 2.1.2.5.

In addition to sealand containers, some drums of slag resulting from the smelting operation will require disposal. The smelting operation will produce an estimated 10\% (by volume) of slag containing the bulk of the contamination from the original material. After being placed into 55-gallon drums, the material will be transported to a LLW landfill. Costs for disposal at commercial and government landfills were estimated to be $\$ 640 / \mathrm{ft}^{3}$ and $\$ 16 / \mathrm{ft}^{3}$, respectively. These values account for transportation and landfill fees.

\subsubsection{9- Cost of Management and Regulatory Compliance}

Cost estimates for regulatory and management activities include planning and management of the various activities conducted by both subcontractor and M\&O staff. These include sampling and surveying, equipment removal, decontamination or smelting, waste packing, and health and safety surveillance. In addition to regular management, a staff will be needed to develop waste management plans, complete the necessary documentation to meet waste acceptance criteria, adhere to regulatory compliance activities to declare equipment and scrap as waste, manifest waste shipments, and correspond to state and federal regulatory agencies. Estimates for the staff requirements to conduct these activities for the recycle option were developed and include the following:

1 Program Manager

1 Project Manager

2 Regulatory Compliance Support Staff

1 Administrative Support Staff

\subsubsection{0-Metal Value}

Once the equipment has been smelted to form ingots or has been segregated and decontaminated as scrap, a variety of options are avallable for consideration by DOE. These include public sale of the metals or reuse within a controlled environment, such as for shielding or construction of radiation waste containers. DOE is currently conducting demonstration projects in these areas. A full economic evaluation of these options is beyond the scope of this study. However, this economic study did attempt to make allowances for the value of the ingots and of the decontaminated scrap. Values for bulk cast iron and steel, as obtained from Metal Working News, were found to be $\$ 0.17$ and $\$ 0.18$ per pound, respectively. 


\subsubsection{Summary of the Metal Recycling Cost Estimates}

Table 2.2a summarizes the cost for recycling the candidate equipment as scrap. The alternative was developed assuming that a free-release criteria could be both approved by DOE and attained by decontamination.

Under this option, more than one million pounds of scrap metal will be produced. Equipment that was not considered for recycle was slated for landfill, and costs calculated accordingly using both governmental and commercial landfill cost estimates.

Table 2.2b below summarizes the cost for recycling the candidate equipment as smelted ingots. The estimated total cost for this option is quite close to that for the scrap metal option because the cost of smelting is close to the total of decontamination plus sampling and survey for the scrap metal option.

Table 2.2a Cost Summary for Metal Recycling-Scrap

\section{Cost Element}

Cost of Removal and Disposal of Hydraulic and Coolant Oils

Cost of Labor and Equipment for Disassembly and Removal to a Staging Area

Cost of Additional Disassembly and Segregation to Prepare for Decontamination

Cost of Decontamination of Scrap Metal for Unrestricted Release Cost of Sampling and Survey Cost of Shipping Containers and Transportation Landfill Fees and Surcharges Cost of Management and Regulatory Compliance Metal Value (Revenue)

Grand Total
Cost Estimate for the Element $\$ 173,000.00$ $\$ 538,000.00$ $\$ 222,000.00$ $\$ 341,000.00$ $\$ 480,000.00$ $\$ 67,500.00$ $\$ 113,000.00^{1} \$ 4,522,000.00^{2}$ $\$ 1,352,000.00$ $(\$ 191,000.00)$ $\$ 3,095,500.00^{1} \$ \$ 7,504,500.00^{2}$

1-Reflects eetimated government disposal rate of $\$ 10 / \mathrm{ft}^{3}$

2-Reflects estimated commercial disposal rate of $\$ 400 / \mathrm{ft}^{3}$. 
Table 2.2b Cost Summary for Metal Recycling-Smelting

Cost Element

Cost Estimate for the Element

Cost of Removal and Disposal

of Hydraulic and Coolant Oils

Cost of Labor and Equipment for

Disassembly and Removal

to a Staging Area

Cost of Additional Disassembly and

Segregation to Prepare for Smelting

Cost of Smelting

Cost of Shipping Containers and

Transportation

Landfill Fees and Surcharges

Cost of Management

and Regulatory Compliance

Metal Value (Revenue)

$\$ 173,000.00$

$\$ 538,000.00$

$\$ 222,000.00$

$\$ 1,210,000,00$

$\$ 67,500.00$

\begin{tabular}{|c|c|}
\hline Grand Total & $(\$ 174,000.00)$ \\
\hline G & $\$ 3,507,800.00^{1} \$ 8,162,500.00^{2}$ \\
\hline
\end{tabular}

1-Reflects estimated government disposal rate of $\$ 10 / \mathrm{ft}^{3}$.

2-Reflects estimated commercial disposal rate of $\$ 400 / \mathrm{ft}^{3}$. 


\section{3}

Reuse Within the Government Sector

The governmental reuse alternative accounts for both decontaminated and contaminated equipment transferred within the government sector according to the provisions set out in 41 CFR 101, Federal Property Management Regulations, and in accordance with current and proposed release criteria established by DOE in Order 5400.5. Building 865 equipment likely to be successfully decontaminated and transferred within the government sector has been identified. A list of these pieces of equipment appears in Appendix F. In addition, contaminated equipment that has the potential to be transferred for use in applications involving radioactivity has been identified, and a list appears in Appendix F. Most of this equipment has the potential to be transferred for reuse within DOE, although transfers to other agencies are within the scope of the projections given here.

According to current guidance, if equipment can be decontaminated to authorized levels, that equipment may be transferred and used within the government sector with no further restrictions. Both current and proposed regulations require documentation that the authorized decontamination limits are justified and will adequately protect members of the public within the basic dose limits.

If contaminated equipment is slated for transfer within the government sector, it must also fall within authorized limits or within supplemental limits established and approved for particular cases. In such transfers, the new equipment owner/agency is responsible for implementing the appropriate administrative controls after transfer, including periodic monitoring; shielding; physical barriers; and radiological safety measures during maintenance, renovation, demolition or other activity that might disturb or cause the radioactive material to migrate.

Equipment likely to be transferred as contaminated for use in a controlled radiological area within DOE has been identified. These pieces of equipment could be transferred to other DOE facilities as a part of normal equipment upgrading, since the equipment at the RFP is high-quality, specialized, and in excellent working order. This equipment can be categorized into two classes-(1) machining, which includes lathes, milling machines, drill presses, and grinders; and (2) metal forming, which includes rolling machines; hydro-formers; and swager, forging forming, extrusion, and isostatic presses.

\subsubsection{Assumptions Underlying the Reuse Alternative}

The following major assumptions were used to develop cost estimates for the reuse option:

- 2-year project life

- Equipment removal, disassembly, reassembly, and packaging conducted by a subcontractor

- Disassembly for decontamination

- Decontamination where appropriate

- Reassembly

- Sampling and survey crew supplied by the M\&O contractor

- Management and regulatory compliance activities will be conducted by a DOE-RFP M\&O contractor staff 
- Packaging and shipping of equipment

- Shipping transportation handled by the agency acquiring the equipment

- Drained oils, coolants, and lubricants are TSCA regulated waste only

- Decontamination waste is classified as a mixed waste

- Decontamination waste management, storage, handling and disposal activities will be conducted by DOE-RFP M\&O contractor staff

- Transfer of equipment results in transfer of the book value of the equipment to the acquiring agency

\subsubsection{Elements of the Reuse Cost Analysis}

Figures 2.3a and 2.3b show schematics of the elements developed to estimate the cost of both release of contaminated and decontaminated equipment from Building 865 for reuse within the government sector. Appropriate cost categories, including operations, management, regulatory compliance, transportation, and disposal were included for each element. A brief description of the cost elements is provided below.

2.3.2.1-Cost of Removal and Disposal of Hydraulic and Coolant Oils See Section 2.1.2.1 for a discussion of this cost element.

\subsubsection{2- Cost of Labor and Equipment for}

\section{Disassembly and Removal to a Staging Area}

The disassembly of equipment and removal of components to a staging area will be conducted as described in Section 2.1.2.2 earlier in this report.

\subsubsection{3-Cost of Additional Disassembly for Decontamination}

Additional disassembly will be required for some of the larger pieces of equipment to allow the removal of the maximum amount of contamination (both beryllium and uranium) and to ensure compliance with release limits and ALARA principles. To estimate the additional cost, the time required for an appropriately qualified, fixed-price, subcontracted disassembly crew was determined for each piece of qualifying equipment. Using the labor rates of the work crew, the additional disassembly costs were estimated. This approach is similar to method used to determine the disassembly cost for removal to a staging area. 


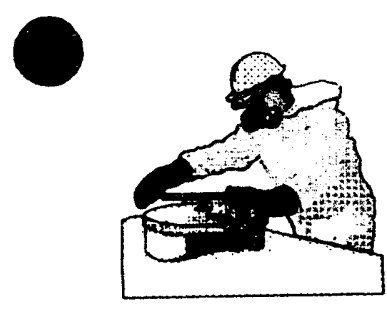

Cost of Removal and

Disposal of

Hydraulic and

Coolant Oils

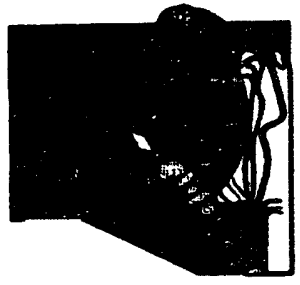

Cost of Reassembly

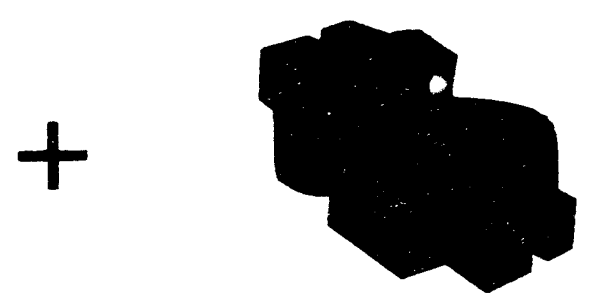

Landfill Fees and Surcharges $t$

Cost of Labor and Equipment for Disassembly and Removal to a Staging Area

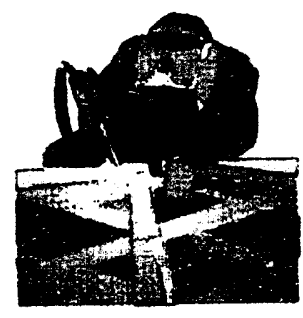

Cost of Additional Disassembly for Decontamination

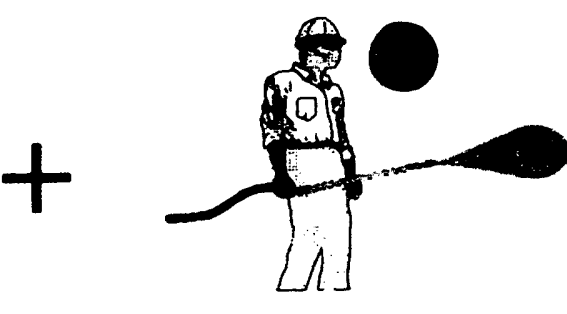

Cost of Decontamination of Equipment for Transfer $\mathscr{v}$

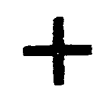

Cost of Sampling and Survey

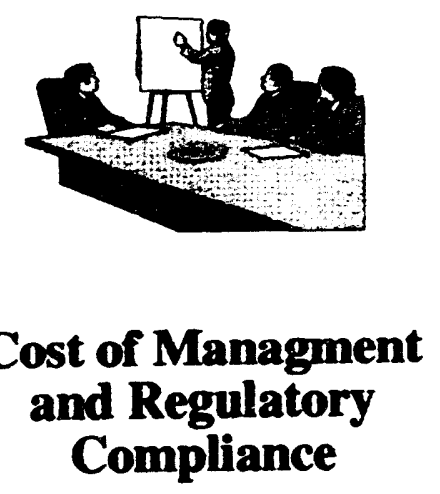

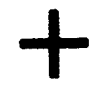

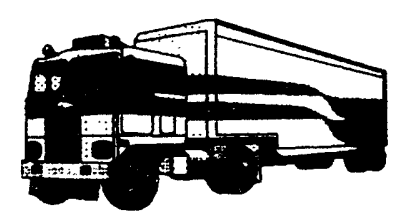

Cost of Shipping Containers and Transportation

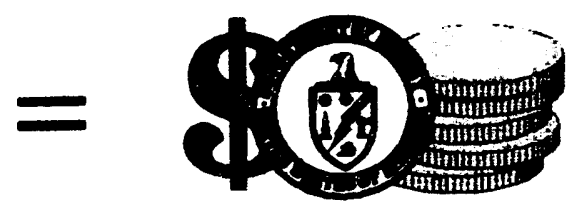

Cost of Transfer for Reuse in the Government Sector Decontaminated

Figure 2.3a 
- 


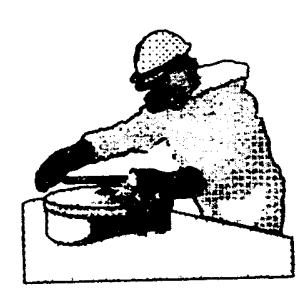

Cost of Removal and Disposal of Hydraulic and Coolant Oils

$\omega$

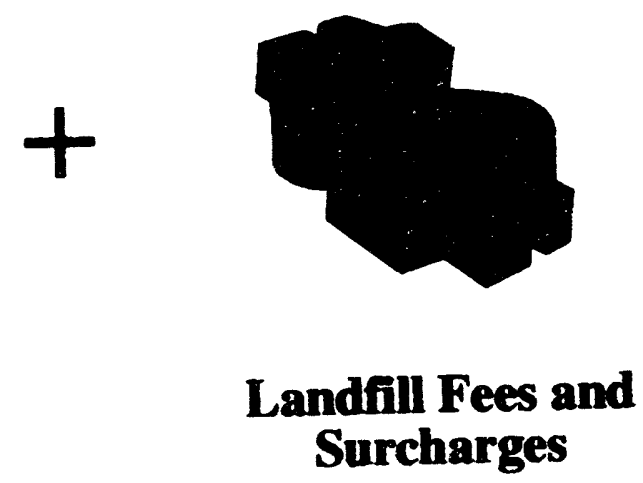

\section{$t$}

Cost of Labor and Equipment for Disassembly and Removal to a

Staging Area

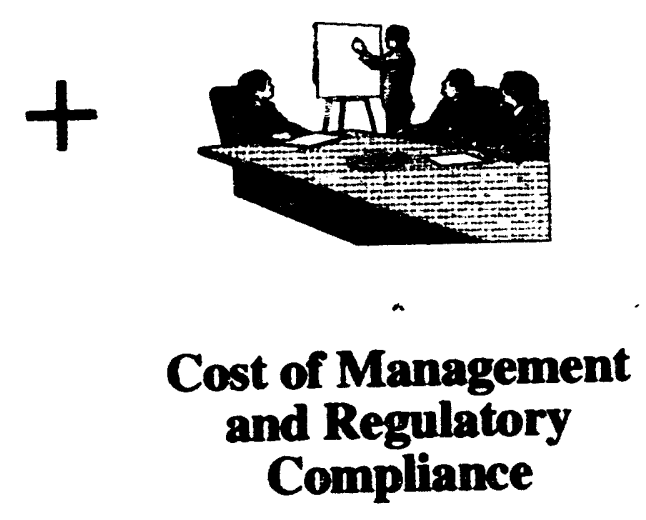

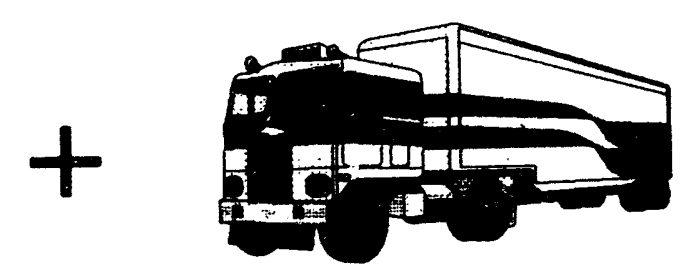

Cost of Shipping Containers and Transportation

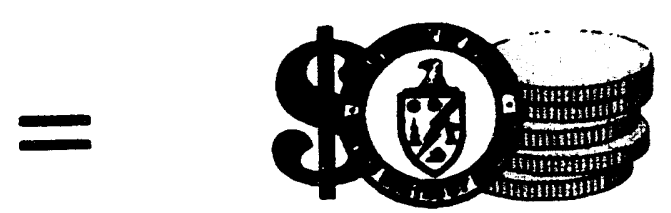

Cost of Transfer for Reuse $n$ the Government Sector Contaminated

Figure 2.3b

Cost Elements for Reuse within the Government Sector Contaminated 


\subsubsection{4 - Cost of Decontamination of Equipment for Transfer}

Decontamination level is dependent on the intended reuse of the equipment within the government sector. The cost for equipment decontamination was developed by first assuming that work crews would be variably comprised, designed to include persons with the minimum skills required to work with particular types of equipment and capable of conducting the level of decontamination necessary to meet the regulatory standards for transfer. Also considered in the estimate was the amount of time necessary to decontaminate each piece of equipment to the appropriate level.

It was assumed that decontamination waste are mixed wastes. The costs for packaging, transport, disposal and material were estimated. Disposal cost for materials are for mixed waste. Landfill fees and surcharges for waste generated during decontamination were included. Waste generated from decontamination efforts consist of HEPA filters which will be compacted into drums.

Since the equipment is intended for reuse, only a limited number of decontamination methods are feasible. Abrasive cleaning or chemical etching will compromise the physical integrity of the equipment components, destroying its precision. Therefore, only high-pressure water and $\mathrm{CO}_{2}$ impingement are viable options. The specifications for a decontamination facility are provided in Appendix $\mathrm{C}$, including descriptions of both high-pressure water and $\mathrm{CO}_{2}$ cleaning methods.

Capital equipment cost for $\mathrm{CO}_{2}$ are considerably higher than those for highpressure water. Capital costs for equipment become comparable when treatment equipment for the wastewater generated by the high-pressure water unit is included. (High-pressure water system generates approximately 4 gallons of wastewater per minute.) In an effort to minimize the generation of wastewater, consideration was given to a closed-loop system that would reuse wastewater for the high-pressure cleaning process, recycling it through a precipitation and filtration system. There are inherent uncertainties associated with this alternative, such as criticality issues and water quality from the treatment system. A full exploration of these issues is beyond the scope of this report. However, once waste treatment costs are compared for the two alternatives, the $\mathrm{CO}_{2}$ decontamination system becomes economically more attractive.

Although the $\mathrm{CO}_{2}$ method is effective for surface cleaning, the long-term attainment of contaminant removal is questionable. Leaching of volumetric contamination following $\mathrm{CO}_{2}$ cleaning may be a possibility. This phenomenon has been reported by the decontamination industry, but so far not documented. The $\mathrm{CO}_{2}$ method is successful in removing loose particles on the equipment surfaces sufficiently to pass the wipe-test as specified by DOE 5400.5 and 5480.11 . Even though the potential for recontamination exists, the levels may still be in compliance with the release criteria. Therefore, estimates in this report are based on the use of a $\mathrm{CO}_{2}$ cleaning system.

Cost estimates for the $\mathrm{CO}_{2}$ cleaning system were developed using data from manufacturers and from RFP. A cost estimate was developed based on an estimate of the square footage required for a treatment facility of adequate size. The estimate 
has built-in allowances for staffing, sampling, waste disposal and repainting.

The assumption used as an end point for decontamination is the removal of all paint. Estimates of the amount of surface area to be cleaned were based on an envelope area that totally enclosed the equipment. Decontamination cost for equipment reuse is based on a $\$ 13.50 / \mathrm{ft}^{2}$ estimate. Estimated costs for individual pieces of equipment ranged from $\$ 100$ to $\$ 35,000$.

\subsubsection{5-Cost of Reassembly}

The cost for equipment reassembly was developed by assuming appropriately qualified crews needed to reassemble the various classes of equipment. Reassembly may be extensive due to the amount of dismantling for the levels of decontamination required. Once the crews were defined the time required for the reassembly of each piece of equipment was estimated. The assumption that reassembly and disassembly are virtually the same was used.

\subsubsection{6-Cost of Sampling and Survey}

Estimates of the amount of survey and sampling required to verify decontamination are based on the level of decontamination required for the particular transfer. The cost for equipment sampling and survey was developed by assuming appropriately qualified crews needed to manually survey and sample the various classes of equipment. Once the crews were defined, the time required for the survey and sampling of each piece of equipment was estimated. This cost includes the use of a two-member health physics sampling crew for the duration of the project.

\subsubsection{7-Cost of Shipping Containers and Transportation}

It was assumed that pallets or custom-built skids would be used for equipment transfer. This arrangement facilitates handling and preserves basic alignment of equipment. After painting, items will be strapped to the pallet to provide stability. Costs are calculated based on the number of pallets plus the number of skids, not the volume of their contents. Costs are essentially the same for both transferring both decontaminated and contaminated equipment. Transportation costs are assumed to be the responsibility of the agency that acquires the equipment. For equipment that does not meet the criteria for this reuse alternative, and therefore requires disposal, cost of shipping containers and transportation is estimated as described in Section 2.1.2.4. Appendix $D$ provides the cost backup.

\subsubsection{8-Landfill Fees and Surcharges}

Cost estimates were developed for burial of sealand containers at both current government facilities and commercial LLW facilities as described in Section 2.1.2.5.

\subsubsection{9- Cost of Management and Regulatory Compliance}

Cost estimates for regulatory and management activities include planning and management of the various activities conducted by both contracted and M\&O staff. These include sampling and surveying, equipment dismantling and 
reassembly, decontamination, waste packing, transfer, and health and safety surveillance. In addition to management, a staff will be needed to develop waste management plans, complete the necessary documentation to meet release acceptance criteria, waste acceptance criteria, adhere to regulatory compliance activities to declare equipment and scrap as surplus, manifest decontamination waste shipments, and correspond to state and federal regulatory agencies. Estimates for the staff requirements to conduct these activities for this reuse option are as follows:

1 Program Manager

1 Project Manager

2 Regulatory Compliance Support Staff

1 Administrative Support Staff

\subsubsection{Summary of the Reuse Cost Estimate}

Table 2.3 summarizes the cost estimate for the transfer of equipment within the government sector. This alternative includes transfer of equipment to both DOE and other federal agencies in accordance with 41 CFR 101. Also included are allowances for decontamination of equipment transferred on an unrestricted basis. 
Table 2.3 Cost Summary for Reuse Within the Government Sector

\begin{tabular}{|c|c|c|}
\hline Cost Element & $\begin{array}{l}\text { Cost Estimates } \\
\text { for Tasks Required } \\
\text { for Both Contam- } \\
\text { inated and Decon- } \\
\text { taminated } \\
\text { Equipment }\end{array}$ & $\begin{array}{l}\text { Additional Cost } \\
\text { Estimates for } \\
\text { Equipment } \\
\text { Requiring } \\
\text { Decontamin- } \\
\text { ation } \\
\end{array}$ \\
\hline $\begin{array}{l}\text { Cost of Removal and Disposal } \\
\text { of Hydraulic and Coolant Oils }\end{array}$ & $\$ 173,000.00$ & - \\
\hline $\begin{array}{l}\text { Cost of Labor and Equipment for } \\
\text { Disassembly and Removal } \\
\text { to a Staging Area }\end{array}$ & $\$ 537,000.00$ & $\overline{-}$ \\
\hline $\begin{array}{l}\text { Cost of Additional Disassembly for } \\
\text { Decontamination }\end{array}$ & $\overline{-}$ & $\$ 82,000.00$ \\
\hline $\begin{array}{l}\text { Cost of Decontamination of } \\
\text { Equipment for Transfer }\end{array}$ & - & $\$ 140,000.00$ \\
\hline Cost of Reassembly & - & $\$ 82,000.00$ \\
\hline Cost of Sampling and Survey & $=$ & $\$ 480,000.00$ \\
\hline $\begin{array}{l}\text { Cost of Shipping Containers and } \\
\text { Transportation }\end{array}$ & $\$ 67,500.00$ & - \\
\hline Landfill Fees and Surcharges & $\begin{array}{r}\$ 113,000.00^{1} \\
\$ 4,522,000.00^{2}\end{array}$ & - \\
\hline $\begin{array}{l}\text { Cost of Management } \\
\text { and Regulatory Compliance }\end{array}$ & $\$ 1,352,000.00$ & $=$ \\
\hline $\begin{array}{l}\text { Subtotals } \\
\text { Grand Total }\end{array}$ & $\begin{array}{l}\$ 2,242,500.00^{1} \\
\$ 6,651,500.00^{2}\end{array}$ & $\begin{array}{c}\$ 784,000.00 \\
\$ 3,026,500.00^{1} \\
\$ 7,435,500.00^{2}\end{array}$ \\
\hline
\end{tabular}

1-Reflects estimated government disposal rate of $\$ 10 / \mathrm{ft}^{3}$.

2-Reflects estimated commercial disposal rate of $\$ 400 / \mathrm{ft}^{3}$. 


\subsection{Unrestricted Sale to Non-Government Organizations}

The unrestricted sale or free-release to non-government organizations alternative allows for the equipment to be categorized as surplus (reference 41 CFR 101) and released in accordance with current and proposed release criteria. Under current and proposed free-release criteria, the equipment cannot exceed a combined (volumetric and surface) dose rate of $100 \mathrm{mrem}$ to the public. Theoretically, once decontamination is achieved, the equipment can be evaluated based on current market value and be utilized, donated or sold on the open market.

The current and proposed regulations require an in-depth examination of the equipment being considered for release. Item description, data on historic use, radiological history, DOE-approved criteria for release, survey description, current radiological condition, quantity and disposition of decontamination waste, and equipment recipient must be disclosed. Additionally, before release, contamination limits are to be evaluated and approved based on the nature of the equipment and its potential use; potential dose to individuals; actual, likely, and worst scenarios; collective dose to the population; and location of closest public contact.

\subsubsection{Assumptions Underlying the Unrestricted Sale Alternative}

The following are the major assumptions used to develop cost estimates for the unrestricted sale option:

- 2-year project life

- Equipment disassembly, removal, reassembly and packaging conducted by a subcontractor

- Disassembly for decontamination

- Decontamination

- Reassembly

- Sampling and survey crew supplied by the M\&O contractor

- Management and regulatory compliance activities will be conducted by a DOE-RFP M\&O contractor staff

- Cost of shipping equipment the responsibility of the buyer

- Drained oils, coolants, and lubricants are TSCA regulated waste only

- Decontamination waste is classified as a mixed waste

- Decontamination waste management storage, handling and disposal activities will be conducted by DOE-RFP M\&O contractor staff

- Sale conducted by a contracted liquidator

\subsubsection{Elements of the Unrestricted Sale Cost Analysis}

Figure 2.4 shows a schematic of the cost elements developed to estimate the cost of free release of the equipment from Building 865. Appropriate cost categories, including operations, management, regulatory compliance, transportation, and disposal were included for each element. A brief description of the cost elements is provided below.

2.4.2.1-Cost of Removal and Disposal of Hydraulic and Coolant Oils See Section 2.1.2.1 for a discussion of this cost element. 
2.4.2.2 - Cost of Labor and Equipment for

Disassembly and Removal to a Staging Area

The disassembly of equipment and removal of components to a staging area will be conducted as described in Section 2.1.2.2 earlier in this report.

2.4.2.3 - Cost of Additional Disassembly for Decontamination

Additional disassembly will be required for some of the larger pieces of equipment will be conducted as described in Section 2.3.2.3 earlier in this report.

2.4.2.4-Cost of Decontamination of Equipment for Unrestricted Release

The cost of decontamination of equipment for unrestricted release was determined as described in Section 2.3.2.4 for the government transfer alternative.

2.4.2.5- Cost of Reassembly

See Section 2.3.2.5 for a discussion of this cost element.

\subsubsection{6-Cost of Sampling and Survey}

See Section 2.3.2.6 for a discussion of this cost element.

2.4.2.7-Cost of Shipping Containers and Transportation

See Section 2.3.2.7 for a discussion of this cost element.

2.4.2.8-Landfill Fees and Surcharges

See Section 2.1.2.5 for a discussion of this cost element.

2.4.2.9-Cost of Management and Regulatory Compliance

Cost estimates for regulatory and management activities include planning and management of the various activities conducted by both contracted and M\&O staff. These include sampling and surveying, equipment dismantling and reassembly, decontamination, waste packing, sale, and health and safety surveillance. In addition to management, a staff wrill be needed to develop waste management plans, complete the necessary documentation to meet release acceptance criteria, waste acceptance criteria, adhere to regulatory compliance activities to declare equipment and scrap as surplus, manifest decontamination waste shipments, and correspond to state and federal regulatory agencies. Estimates for the staff requirements to conduct these activities for the free-release option are as follows:

1 Program Manager

2 Project Managers

8 Regulatory Compliance Support Staff

3 Administrative Support Staff 


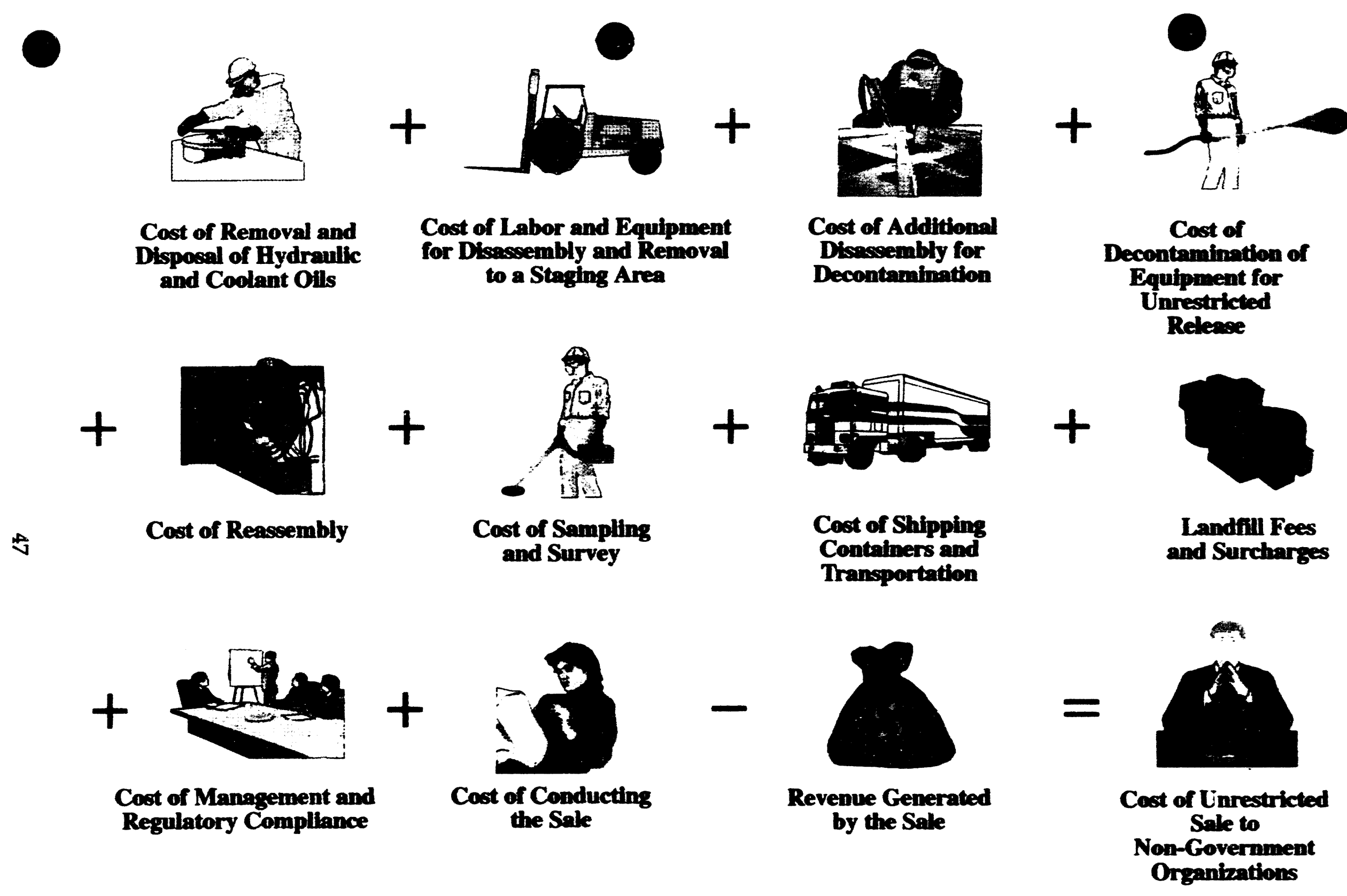

Figure 2.4

Cost of Elements for Unrestricted Sale to Non-Government Organizations 
2.4.2.10-Cost to the Government for Conducting the Sale

The cost of conducting the sale, including advertising and warehousing the equipment for public view is based on a percentage of the total sale price of the equipment. Discussions with local liquidators and auction companies identified a range of cost for these services as $15-20 \%$ of the sale price. An average of $18 \%$ was used for the cost estimate. Included below is a list of Rocky Mountain Equipment Brokers that may serve in this capacity.

Table 24a

Rocky Mountain Equipment Brokers

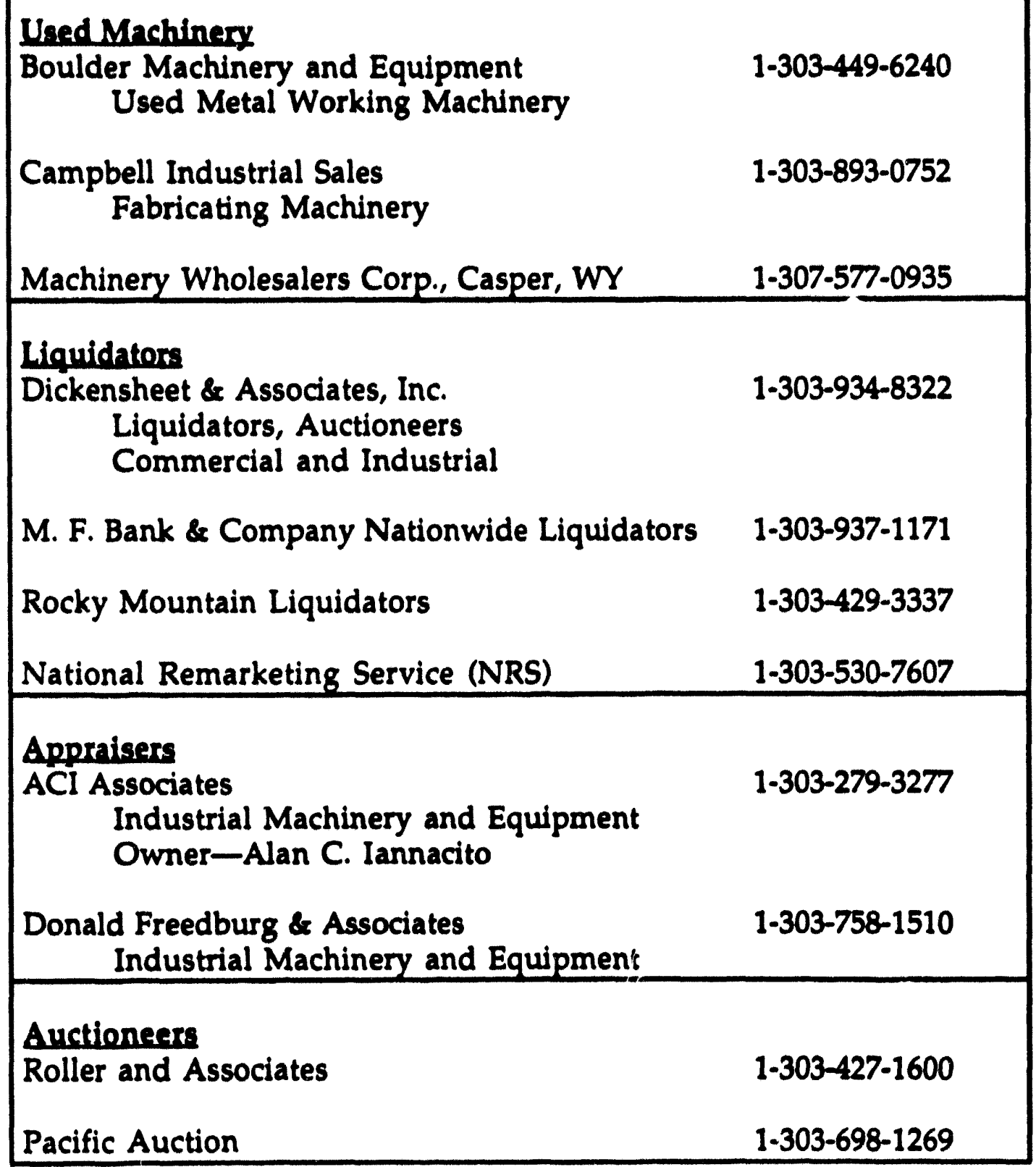




\subsubsection{1-Revenue Generated by the Sale}

The revenue generated by the sale of equipment was developed by estimating the fair market value of the equipment. First, acquisition costs were converted to present value dollars using DOE escalation factors to determine a replacement value. Next, a discount factor of approximately $40 \%$ was applied to determine the fair market value of the used equipment. Calculated values were discussed with brokers and liquidators as a validation, and found to be reasonable. The actual sale price may vary widely and depends greatly on the working order and overall shape of the equipment as well as the advertising and timing of the sale. Experienced brokers are knowledgeable of market conditions and are usually more effective at attracting larger numbers of qualified buyers as well as timing the sale during peak demands. In addition, having several smaller sales, as opposed to one large sale, will likely result in a higher sale price. The expected sale price of the equipment is provided in Appendix B, with a discussion of the estimation method in Appendix D. 


\subsubsection{Summary of the Unrestricted Sale Cost Estimate}

Table 2.4b summarizes the costs estimates for the public sale alternative. The cost estimate for this option includes consideration of decontamination to a release limit determined by the proposed method outlined in 10 CFR 834. All costs for documentation in accordance with the proposed guidelines are included in this cost estimate.

Table 2.4b Cost Summary for Unrestricted Sale to Non-Government Organizations

\begin{tabular}{|l|c|}
\hline Cost Element & Cost Estimate for the Element \\
\hline $\begin{array}{l}\text { Cost of Removal and Disposal } \\
\text { of Hydraulic and Coolant Oils }\end{array}$ & $\$ 173,000.00$ \\
\hline $\begin{array}{l}\text { Cost of Labor and Equipment for } \\
\text { Disassembly and Removal } \\
\text { to a Staging Area }\end{array}$ & $\$ 537,000.00$ \\
\hline $\begin{array}{l}\text { Cost of Additional Disassembly for } \\
\text { Decontamination }\end{array}$ & $\$ 222,000.00$ \\
\hline $\begin{array}{l}\text { Cost of Decontamination of Equipment for } \\
\text { Unrestricted Release }\end{array}$ & $\$ 223,000.00$ \\
\hline Cost of Reassembly & $\$ 222,000.00$ \\
\hline Cost of Sampling and Survey & $\$ 480,000.00$ \\
\hline $\begin{array}{l}\text { Cost of Shipping Equipment and } \\
\text { Transportation }\end{array}$ & $\$ 67,500.00$ \\
\hline Landfill Fees and Surcharges & $\$ 113,000.001$ \\
& $4,522,000.00^{2}$ \\
\hline $\begin{array}{l}\text { Cost of Management } \\
\text { and Regulatory Compliance }\end{array}$ & $\$ 3,384,000.00$ \\
\hline Cost of Conducting the Sale & $\$ 439,000.00$ \\
\hline Revenue Generated by the Sale (Revenue) & $(\$ 2,439,000.00)$ \\
\hline & $\$ 3,421,500.001$ \\
\hline \multicolumn{1}{|c|}{ Grand Total } & $\$ 7,830,500.00^{2}$ \\
\hline
\end{tabular}

1-Reflects estimated government disposal rate of $\$ 10 / \mathrm{ft}^{3}$.

2-Reflects estimated commercial disposal rate of $\$ 400 / \mathrm{ft}^{3}$. 


\subsection{Comparison of Economic Alternatives}

In this section, the total cost estimate for each of the recycling/reuse alternative are compared to the baseline. While tabulated results are presented below, total costs are not the only factors for consideration in determining which option offers the greatest cost savings to the government. Additional factors for consideration are presented in Section 2.5.2.

The results presented here are not intended to determine the course of action to pursue, but are offered as input for discussions as to the need for changes in policies that limit recycle/reuse options within DOE. Clearly, the optimal cost savings to the government for these types equipment disposition challenges uill involve establishing policies that accomplish two objectives. First is protecting the public in accordance with accepted risk factors. Second is allowing DOE sites to realistically consider several recycle/reuse alternatives for each piece of equipment.

\subsubsection{Overview of Potential Cost Savings Compared to Baseline Alternative}

To determine the economic advantages of implementing the recycle/reuse options instead of the baseline option, the decrease in cost was determined for each option and is presented in Table 2.5 below. All options offer a decrease in the total cost to the government compared to the baseline landfill option. The range of cost savings is $\$ 1,827,500$ (38\%) for transfer within the government to $\$ 1,346,200(28 \%)$ for recycling smelted metal, both assuming the use of a government waste disposal site. When using commercial disposal costs, recycle/reuse alternatives offer a potential cost savings of up to $\$ 25,600,000$ compared to landfill disposal.

Table 25 Comparison of Economic Alternatives

\begin{tabular}{|c|c|c|c|c|}
\hline \multirow{2}{*}{$\begin{array}{l}\text { Alternative } \\
\text { Landfill (Baseline) }\end{array}$} & \multicolumn{2}{|c|}{ Estimated Cost } & \multicolumn{2}{|c|}{$\begin{array}{l}\text { Cost Increase } \\
\text { (or Decrease) } \\
\text { Compared to Baseline }\end{array}$} \\
\hline & $\$ 4,854,000^{1}$ & $\$ 33,130,000^{2}$ & - & \\
\hline $\begin{array}{c}\text { Recycle } \\
\text { Scrap } \\
\text { Smelt }\end{array}$ & $\begin{array}{l}\$ 3,095,500^{1} \\
\$ 3,507,800^{1}\end{array}$ & $\begin{array}{l}\$ 7,504,500^{2} \\
\$ 8,162,500^{2}\end{array}$ & $\begin{array}{l}(\$ 1,758,500) \\
(\$ 1,346,200) \\
1\end{array}$ & $\begin{array}{l}(\$ 24,967,500)^{2} \\
(\$ 24,619,500)^{2}\end{array}$ \\
\hline Government Transfer & $\$ 3,026,500^{1}$ & $\$ 7,435,500^{2}$ & $(\$ 1,827,500)^{1}$ & $(\$ 25,600,500)^{2}$ \\
\hline $\begin{array}{l}\text { Unrestricted } \\
\text { Sale to the Public }\end{array}$ & $\$ 3,421,500^{1}$ & $\$ 7,830,500^{2}$ & $(\$ 1,432,500)^{1}$ & $(\$ 25,300,000)^{2}$ \\
\hline
\end{tabular}

1-Reflects estimated government disposal rate of $\$ 10 / \mathrm{ft}^{3}$

2-Reflects estimated commercial disposal rate of $5400 / \mathrm{ft}^{3}$

\subsubsection{Uncertainties}

Each alternative under consideration has inherent uncertainties that impact the viability of implementing that option. This section discusses the uncertainties associated with each alternative that should be considered along with the potential for cost savings. 
Landfill. The major uncertainties for the landfill alternative involve restrictions on this option posed by waste minimization considerations and the availability of government landfill space. Meeting acceptance criteria for disposal at the NTS and Hanford requires considerable effort by individual Field Offices and must be obtained for each waste stream (Building 865 equipment may be considered a waste stream). In addition, surplus and scrap equipment must be properly classified and documented as having no economic value, and thus waste in accordance with the applicable sections of 41 CFR 101 and 48 CFR 45.

Metal Recycling. Recycling metal as scrap is economically favored over the smelting option. The major uncertainty of implementing either of these options is the absence of a free-release criteria for volumetrically contaminated metal. Although release is feasible under current DOE and NRC guidelines, the procedure is not well defined or tested, and it requires approval within the highest levels of DOE. However, efforts are currently underway to establish clearer guidelines through agreement between EPA, NRC, and DOE.

DOE is currently pursuing demonstrations to use materials in environments where residual contamination does not adversely affect the public or the environment. Examples are waste packing boxes and shielding. Overall, these options are likely to have a relatively small economic impact, since the expected volume of metals from $D \& D$ actions throughout $D O E$ will quickly outpace the demand for these materials.

Policy guidance drafted by DOE ( 10 CFR 834) applies a graded approach to establishing release limits that are dependent on the final use of the material. Under this approach, higher limits would be tolerated for material to be used in situations in which there will be little or no exposure to the public or the environment. Using this approach, a wide variety of uses may be possible, such as structural steel and rebar for concrete. However, the DOE would have to ensure and document that material released for reuse in these low exposure scenarios could not find its way into a more general use.

Cost estimates for decontamination were difficult to develop. Commercial decontamination companies are reluctant to divulge their cost data, and the literature offers only gross estimates appropriate for data checks for this study. In addition, the true surface area was estimated based on an encompassing envelope. The decontamination estimates were based on the time of $\mathrm{CO}_{2}$ impingement necessary to remove paint, as it was assumed that this would be sufficient to meet a developed release criteria. In the absence of more definitive decontamination data, the estimates appear to be reasonable.

. Transfer Within the Government. This alternative offers the greatest potential for cost savings to DOE based on the economic analysis. This is not surprising since the options allows for the transfer of selected contaminated equipment, eliminating the cost associated with disassembly for decontamination, for decontamination, and for reassembly. Even though the potential for cost savings can be demonstrated, the likelihood for much of the equipment to be transferred is very low. Both the DOE and DoD have experienced major reductions in programs that support defense programs, programs that would have a use for this equipment for $R \& D$, production, or maintenance. 
Unrestricted Release to the Public. This alternative has the second highest potential for cost savings for DOE. Discussions with brokers and appraisers indicated that a strong demand for this equipment could be expected, and that, assuming proper marketing, the estimated sale prices are reasonable.

As stated previously, cost estimates for decontamination were difficult to develop. But again, in the absence of more definitive decontamination data, the estimates appear to be reasonable.

The major uncertainty for the unrestricted sale of equipment to the public is the lack of a definitive release policy with defined free-release criteria, although a draft DOE policy (10 CFR 834) is currently under review. Under the current regulatory environment, where considerations for potential liabilities for harm to the public and the environment have a major impact on decision making, many sites are reluctant to authorize the release of potentially contaminated equipment.

The proposed policy provides an outline for developing a release criteria. The policy considers the expected use of the equipment in establishing this limit and requires approval from DOE Headquarters. It appears that equipment can be grouped based on similarities for usage or function in the development of a release limit. Results of a sample release scenario have been provided in Section 3.1.

In summary, this information on economic and policy considerations should prove useful in developing plans for the final disposition of the Building 865 equipment. The majority of the impediments to implementing the most attractive economic alternatives relate to policy and institutional reluctance. Changes in policies and training to overcome ingrained biases against unrestricted release of previously contaminated equipment are needed. The following sections discuss policies that affect the alternatives presented here as well as some institutional constraints. 


\subsection{Policy Implications}

One aspect of planning and conducting decontamination and decommissioning activities at DOE facilities warrants detailed analysis in light of DOE's relatively new emphasis on D\&D. That is, the regulatory guidance and current interpretation of that guidance as pertaining to the recycling or reuse of equipment and other material. Vast amounts of natural resources previously required by DOE facilities for defense and other related programs now await disposition. The time is right for carefully analyzing current policies, regulations, guidelines, accepted approaches, and cultural mores that arose at a time when D\&D issues were not at the forefront of planning considerations. The aim of the analysis could be to bring D\&D issues to the forefront to streamline and standardize approaches to such D\&D activities as recycling, transferring, or selling equipment now in the DOE inventory. Policies should be optimized to facilitate the use of resources while not compromising the environment or human health. (IAEA, 1988)

As indicated by Section 2 of this report, much of the material in Building 865 at the RFP has commercial value, either as it currently exists or in some recycled form. These resources will realize their full value either if the radionuclide content of the items currently does not exceed or can be reduced to prescribed levels. The discussion in this section attempts to introduce the pertinent national and international policy considerations and some potential site-specific problems for addressing both surface and volumetric contamination of RFP equipment within accepted guidelines.

\subsection{U.S. Department of Energy Guidance}

As the owner of the equipment at the RFP, DOE has primary responsibility for properly managing contaminated equipment in a manner that protects workers, the public, and the environment. DOE has developed policies to ensure proper control, and may also rely on policies developed by other agencies, including state, federal, and international organizations.

DOE operations involving the release of equipment having residual radioactive material are governed by the DOE Order 5400.5-Radiation Protection of the Public and the Environment. This order establishes standards and requirements for release of equipment. Provisions for restricted and unrestricted release are not clearly stated, but are implied within the general wording of the standard regarding supplemental limits. By promulgating this order, DOE achieves its objective to operate facilities and conduct activities so that radiation exposure to members of the public are as low as reasonably achievable (ALARA). The order requires the development of an ALARA program for all DOE operations (DOE 5400.5, CH 2, p II-5).

Under DOE order 5400.5 (CH 2, p II-10), all property is considered potentially contaminated if it has been used or stored in a radiation area. Prior to release, the equipment must be surveyed using appropriate instruments and techniques to determine if the removable and fixed surface contamination meet release criteria. 5400.5 provides contingency plans for the release of property with inaccessible areas, 
calling for a case-by-case evaluation and documentation demonstrating that any contamination in the inaccessible areas is likely to be within acceptable limits.

5400.5 (CH 4, p IV-6) establishes "general surface contamination guidelines" that are generally consistent with standards of the NRC, as stipulated in the Regulatory Guideline 1.86 (USAEC, 1974). The guidelines in 5400.5 specifically address surface contamination only.

Currently, DOE 5400.5 does not specifically state limits for releasing volumetrically contaminated or activated equipment (e.g., radioactivity per unit volume or per unit mass), but, such equipment or material may be released if criteria and survey techniques are approved by the Office of Environmental Health and Safety, DOE Headquarters, Assistant Secretary for Environmental Health and Safety (EH-1) as stated in CH 2, p II-10.

5400.5 requires the records of any release to include a description of the property, date of last survey, identity of the surveyor (and organization), type and identification of monitoring instruments, results of the monitoring operation, and identity of the recipient of the released equipment. It establishes basic dose limits to the public for exposure to residual radioactive material at $100 \mathrm{mrem}(1 \mathrm{mSv})$ effective dose equivalent in a year. A demonstration of compliance with basic dose limit is also required.

5400.5 promulgates authorized limits for residual radioactive material. This provision states that authorization of limits for each property shall be equal to the generic or derived guidelines unless it can be established, on the basis of specific property data, that the guidelines are not appropriate for use for the specific property. The authorized limits shall be established to provide, at a minimum, that the basic dose limits of $100 \mathrm{mrem} / \mathrm{yr}$. will not be exceeded under the worst case or plausible-use scenarios.

5400.5 provides for the development of Supplemental Limits and Exceptions (CH 4, p IV-9). If a specific property's potential use indicates that the guidelines or authorized limits for release are not appropriate for any portion of that property, the operations office may request that supplemental limits or an exception be applied.

The responsible operations office must document the decision that the guidelines or authorized limits are not appropriate and that the alternative action selected will provide adequate protection, giving due consideration to health and safety, the environment, costs and public policy. Any supplemental limits are to fall within the basic dose limit of $100 \mathrm{mrem} / \mathrm{yr}$. for both current and potential unrestricted use of the property and the supplemental limits require documentation and evaluation on a case-by-case basis.

Like 5400.5, 10 CFR 834, Proposed Rule, Subpart D-Release and Evaluation for Release of Property Having Radioastive Material, spells out requirements for decontamination, survey, management, storage, disposal, and release of buildings, land, equipment, and personal property containing residual radioactive material. The proposed rule differs from DOE 5400.5 essentially in format rather than substance. It maintains the stance that all releases of property are to be assessed and the ALARA principle applied no matter how small the dose. The proposed rule also maintains the established primary dose limit of $100 \mathrm{mrem} / \mathrm{yr}$.

However, upon closer inspection of the proposed rule, subtle difference can 
be noted that have implications for the release of equipment, including releases to non-government organizations. In the proposed rule, unlike 5400.5, requirements for restricted and unrestricted release criteria are clearly indicated. The proposed rule would require that assessments of potential doses associated with releases be specific to the particular release considered and that all subsurface contamination, such as contamination in depth (i.e. mass concentration or volumetric contamination) be assessed and limits established consistent with the principles set forth in proposed Subpart D. It specifically states that DOE must review and approve authorized limits before properties with residual radioactive material are released to members of the general public for unrestricted use. Note that the proposed rule does allow for the potential of free release of equipment previously used in radiation areas.

The proposed rule specifically provides for the development of authorized and supplement limits for both unrestricted and restricted use. It is stricter than DOE Order 5400.5 in the requirements for supporting documentation verifying that ALARA and release criteria have been accomplished.

Basic steps for equipment release contained in Section 834.301-Release of Property Containing Residual Radioactive Material, are as follows:

1. Evaluation of the historical use of property prior to release to determine if it has been subjected to radiological contamination

2. Item survey characterization, including mass contamination, removable surface radioactive material, and total surface radioactive material

3. Current and future use of property assessment and evaluation

4. Establishment of authorization limits for releașe actions (calculate exposure from equipment or property from future use scenarios)

5. Approval of any release by DOE Headquarters with documentation that: describes the item, describes its radiological history, states the proposed criteria for release of the property, describes the survey of the item, indicates the radiological condition of the property, indicates the quantity and disposition of the waste resulting from any decontamination effort, and identifies the recipient of the property

The evaluation of current and future use would consider "actual," "likely," and "worst" plausible use of the property over the long run. Allowable doses for release of the properties calculated under any "worst plausible" scenario may be relatively large fractions of the general dose limit if the probability of that scenario occurring is relatively low. In cases where the probability of the "worst plausible" scenario is high, potential doses associated with the release would be limited to a relatively small fraction of the $100 \mathrm{mrem} / \mathrm{yr}$. dose limit.

Persons responsible for the decontamination and release of property with residual radioactive material subject to the proposed rule would ensure that the property to be released has been assessed and potential impacts are appropriately documented.

Authorized limits, set by DOE and regulated under Section $834.302-$ Authorized Limits, shall be based on the nature of the property and its potential use, and on the potential dose to an individual in:

(1) the actual and likely use scenario to ensure that potential 
doses are not likely to exceed a small fraction of the applicable dose limits in this part and applicable dose limits in this part and (2) the worst plausible use scenario to ensure that potential doses are not likely to exceed the applicable dose limits in this part DOE may authorize for a particular DOE activity, supplemental limits, regulated under Section 834.310-Supplemental Limits, for the release of property containing residual radioactive material in lieu of any general limits authorized under this Subpart if:

- Remedial action consistent with authorized limits would pose a clear and present risk of injury to workers or members of the public, notwithstanding reasonable measures to avoid or reduce risk.

- Remedial action consistent with authorized limits, even after all reasonable mitigative measures have been taken, causes environmental harm that is clearly excessive compared to the health benefits to persons living on or near affected properties now or in the future.

- It is determined that the scenarios or assumptions used to establish the authorized limits do not apply to the property identified or where more appropriate scenarios or assumptions indicate that other limits are applicable or appropriate for protection of the public and environment.

- The cost of remedial action for contaminated soil is unreasonable high relative to long-term benefits and where the residual material does not pose a clear present or future risk after taking necessary control measures.

- There is no feasible remedial action that can achieve the authorized limits and supplemental limit shall achieve the dose and ALARA requirements of this part for any current of future use of the property and shall contain any restriction necessary to achieve the objectives of this part.

Using accepted risk assessment techniques, an acceptable level of volumetric contamination for free release can be calculated. Using the modeling software, ISOSHLD, the regulatory exposure dose rate of $100 \mathrm{mrem} / \mathrm{yr}$, and the assumptions listed, the permissible limit for uranium activity in a piece of equipment can be calculated.

The levels of contamination calculated in the example that follows can be readily measured using hand-held instruments under the current conditions in Building 865. Thus, under present and proposed DOE regulations, permissible limits for free release can be established on a case-by-case basis. 
Table 3.1-Sample Calculation To Establish Authorized or Supplemental Limits for Volumetric Contamination for Unrestricted Equipment Release

\begin{tabular}{|c|c|}
\hline Requirement: & $\begin{array}{l}\text { Characterization of volumetric contamination } \\
\text { requires that the activity }(\mu \mathrm{Ci} / \mathrm{cc}) \text { of radionuclides } \\
\text { be established. }\end{array}$ \\
\hline Nuclide of Concern: & Depleted Ura: ium-238 \\
\hline Equipment for Release: & Lathe Machine \\
\hline Exposure Limit: & $\begin{array}{l}100 \mathrm{mrem} / \mathrm{yr} \text {. (total exposure from both surface } \\
\text { and volumetric contamination) }\end{array}$ \\
\hline Modeling Assumptions: & $\begin{array}{l}\text { The contamination consists of U-238 that is a by product } \\
\text { of uranium enrichment. Since it is extremely chemically } \\
\text { pure, no long-term daughter products have built up since } \\
\text { enrichment, except for a minor amounts ( } 1.4 \mathrm{E}-2 \% \text { ) of } \\
\text { U-234. A small amount ( } 0.5 \% \text { ) of U-235 also remains in } \\
\text { the containment after the enrichment process. Thus, the } \\
\text { ratio of isotopes in the containment (in } \mu \mathrm{CI} / \mathrm{cc} \text { ) is } \\
1 / 0.005 / 0.00014 \text { of U-238/U-235/U-234. } \\
\text { All loose surface contamination has been removed, so that } \\
\text { the radiation consists of beta and gamma only. Thus, the } \\
\text { conversion factor between rem and rad is } 1 \text {. } \\
\text { The operator works at the machine for } 40 \text { hours per week } \\
\text { for } 50 \text { weeks per year, or } 2,000 \text { hours per year. Thus, the } \\
\text { allowable exposure rate is } 5 E-5 \text { R/hour. } \\
\text { The machine is modeled as a cylinder of length } 241.5 \mathrm{~cm} \\
\text { and radius } 144.8 \mathrm{~cm} \text {. The cylinder is composed of a } \\
\text { homogenous mixture of iron and air of density } 3.9 \mathrm{~g} / \mathrm{cc} \text {, } \\
\text { approximately modeling the interior spaces in the real } \\
\text { equipment. The contamination is homogeneously } \\
\text { distributed throughout the cylinder. } \\
\text { The "reasonable and likely" location at which the } \\
\text { exposure is measured is one cm outward from the cylinder } \\
\text { surface (145.8 cm from the cylinder center line) and } 73.3 \mathrm{~cm} \\
\text { from one end. }\end{array}$ \\
\hline Aim of the Calculation: & $\begin{array}{l}\text { Determine the allowable activity of depleted uranium } \\
\text { contamination for the lathe machine targeted for free-release } \\
\text { that is compatible with the current } 100 \mathrm{mrem} / \mathrm{yr} \text {. total } \\
\text { exposure limit. }\end{array}$ \\
\hline Model Used: & ISOSHLD \\
\hline Source Activity Limits: & $\begin{array}{l}1.950 \times 10-5 \\
5.000 \times 10-7 \\
3.900 \times 10-3\end{array}$ \\
\hline
\end{tabular}




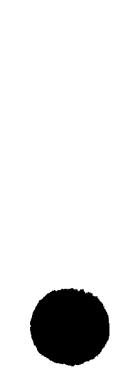

$\bullet$ 


\subsection{International Experience}

Approximately 288 nuclear installations could be decommissioned within the next twenty to thirty years. A colossal amount of metals, equipment and other materials will result, all of which will either have to be recycled, reused or disposed of as waste. If dismissed out of hand as waste with no effort to establish release criteria, this material will place a tremendous burden on already stressed disposal facilities. Therefore, due to the amount of potentially reusable material foreseen, a desirable internationally accepted criteria should be developed for the release of components arising from the decommissioning of nuclear facilities. (IAEA, 1988)

The development of such international standards is of interest to DOE since it commonly adopts internationally accepted standards or uses them in the development of its own radiation protection standards. The following sections provide a brief discussion of international agencies involved in standards and policies.

\subsubsection{International Commission on Radiological Protection}

DOE currently adopts and implements radiation protection dose standards consistent with the recommendations of the ICRP. In 1977, the ICRP recommended a system of dose limitations that has been adopted and implemented by essentially all countries with nuclear programs. The ICRP system of dose limitations provides a scientific basis for health protection and selection of dose limits. The system also reflects current information on health risk, dosimetry, and radiation practices, and promotes a more uniform and consistent application of radiation protection among diverse activities than had previously been possible. The ICRP system is based on sophisticated analytical models and requires computer capabilities for making evaluations or using the dose conversion tables produced from such evaluations.

The principle objective of ICRP is to protect man from undue radiation exposure from current and future sources. The objective is applicable to all radiological work including the recycling/reuse of components from nuclear programs. The system of dose limitation as laid down by ICRP in Publication 26, and subsequently adopted by the IAEA, the NRC and DOE, contains three essential components:

Justification of a practice

Optimization of radiation protection

Individual dose limitation

Iustification. In order to prevent unnecessary exposure, no practice involving exposure to ionizing radiation shall be adopted unless its introduction produces a positive net benefit.

Optimization. All exposure to radiation is assumed to involve some degree of risk, and the optimization of radiation protection requires that exposure should be kept ALARA, economic and social factors taken into consideration. This can be interpreted as meaning that the detriment associated with the practice under consideration should be appropriately small in relation to the benefit resulting form it. The detriment is the harm to health caused by the practice and is assumed to be proportional to the total radiation dose to the population as a whole.

Dose limitation. Dose limits are necessary as an overriding limit on the risk to the 
individuals. They may be regarded as the lower bound of a region of unacceptable risk. Recommendations on the individual dose limits are given by ICRP in Publication 26.

Practices involving the release of components from the decommissioning of nuclear installations are controlled on the basis of these principles of radiological protection. If unrestricted release is intended, it is necessary to demonstrate that the radiological risk associated with the practice are trivial. The IAEA has issued a recommended policy to establish if a dose is trivial.

\subsubsection{International Atomic Energy Agency}

In 1988, the IAEA issued Safety Guide \#89, Principles for the Exemption of Radiation Sources and Practices for Regulatory Control. The purpose of this safety guide was to recommend a policy on exemption of radiation sources and practices from regulatory program. The IAEA recommendations on individual and related risks consider two main approaches in deciding whether a dose is trivial. The first consideration is risk-based, and the recommended level of trivial effective dose equivalent is in the range of $1-10 \mathrm{mrem} / \mathrm{yr}$. The other consideration is based on comparison with the natural background radiation, a small dose that can be regarded as trivial. The recommended whole body or effective dose is a few percent of the natural background, i.e., 1-10 mrem/yr. The IAEA draws the conclusion that an individual radiation dose, regardless of its origin, may be regarded as trivial if it is of the order 1-10 mrem/yr. DOE's guidance requiring report of release events of greater than $10 \mathrm{mrem}$ is consistent with this policy. (DOE, August 1991)

\subsubsection{International Criteria for Unrestricted Release}

Several countries having nuclear facilities have established permissible levels of surface and volumetric contamination for objects intended to be removed form controlled areas (i.e. unrestricted release). Some of the criteria used for unrestricted release of materials are shown in the following table, along with their corresponding country and released material. (IAEA, 1988) 
Table 3.2 International Release Criteria

\begin{tabular}{|c|c|c|c|}
\hline Country/Facility Type & Remarks & $\begin{array}{l}\text { Unrestricted } \\
\text { Surface }\end{array}$ & $\begin{array}{l}\text { Tease Limits: } \\
\text { Volumetric } \\
\text { (fixed) }\end{array}$ \\
\hline $\begin{array}{l}\text { France-- } \\
3 \text { uranium processing } \\
\text { plants in Le Bouchet, } \\
\text { Gueugnon, and Forez }\end{array}$ & $\begin{array}{l}\text { Plants and sites } \\
\text { released for URU. } \\
1400 \mathrm{t} \text { steel scrap } \\
\text { released for URU. } \\
900 \mathrm{t} \text { of equipment } \\
\text { released for use in } \\
\text { similar plants. }\end{array}$ & $\begin{array}{l}0.2 \mathrm{~Bq} / \mathrm{cm}^{2} \\
\text { (alpha) } \\
7.5 \mu \mathrm{Hv} / \mathrm{h} \\
(\mathrm{beta}) \\
1.25 \mu \mathrm{Sv} / \mathrm{h} \\
\text { (gamma) }\end{array}$ & $\begin{array}{l}0.2 \mathrm{~Bq} / \mathrm{cm}^{2} \\
\text { (alpha) }\end{array}$ \\
\hline $\begin{array}{l}30,000 \text { drums }(750 t) \text { per } \\
\text { year Uranate transport }\end{array}$ & $\begin{array}{l}\text { Decontaminated, } \\
\text { remelted, and released } \\
\text { for URU. }\end{array}$ & $\begin{array}{l}74 \mathrm{~Bq} / \text { drum } \\
\text { (alpha) }\end{array}$ & - \\
\hline $\begin{array}{l}\text { Germany-- } \\
\text { Gundremmingen-A } \\
\text { NPP, } 250 \text { MW(E) }\end{array}$ & $\begin{array}{l}1100 \mathrm{t} \text { metal and } 400 \mathrm{t} \\
\text { concrete release for } \\
\text { URU. }\end{array}$ & $0.37 \mathrm{~Bq} / \mathrm{cm}^{2}$ & $3.7 \mathrm{~Bq} / \mathrm{g}$ \\
\hline $\begin{array}{l}\text { Würgassen NPP } \\
\text { refurbishment }\end{array}$ & $\begin{array}{l}140 \mathrm{t} \text { of steel melted } \\
\text { and used to make } \\
\text { waste containers for } \\
\text { service in nuclear } \\
\text { stations. } 100 \mathrm{t} \text { metal } \\
\text { srap remelted and } \\
\text { released for URU. }\end{array}$ & $0.37 \mathrm{~Bq} / \mathrm{cm}^{2}$ & $3.7 \mathrm{~Bq} / \mathrm{g}$ \\
\hline $\begin{array}{l}\text { Nuclear ship } \\
\text { Otto Hahn }\end{array}$ & $\begin{array}{l}\text { Contaminated } \\
\text { components removed; } \\
\text { ship released for URU. }\end{array}$ & $0.37 \mathrm{~Bq} / \mathrm{cm}^{2}$ & $3.7 \mathrm{~Bq} / \mathrm{g}$ \\
\hline $\begin{array}{l}\text { Sweden-- } \\
\text { R-1 research reactor, } \\
1 \text { MW (Stockholm) }\end{array}$ & $\begin{array}{l}\text { Facility components } \\
\text { released for URU. } \\
15 \% \text { of scrap metal } \\
\text { recycled for URU. } \\
15 \text { Ot remelted for } \\
\text { L U since } 1982 .\end{array}$ & $8 \mathrm{KBq} / \mathrm{m}^{2}$ & 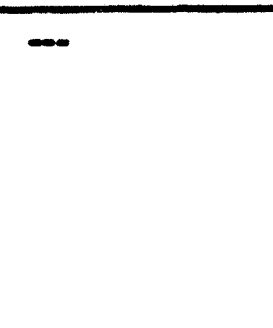 \\
\hline $\begin{array}{l}\text { Nuclear reactor heat } \\
\text { exchange tubes }\end{array}$ & $\begin{array}{l}\text { Used for production of } \\
\text { ship propellers and } \\
\text { similar items. }\end{array}$ & $\begin{array}{c}500 \mathrm{~Bq} / \mathrm{kg} \\
\text { (gamma) }\end{array}$ & - \\
\hline
\end{tabular}


○

○ 


\subsection{U.S. Environmental Protection Agency Involvement}

According to DOE Order 5400.5, Real Properties owned by DOE that are being sold to the public are subject to the requirements of Section 120(h) of the Comprehensive Environmental Response Compensation and Liability Act (CERCLA), as amended. The requirements of 40 CFR Part 192 are applicable to properties remediated by DOE under Title I of the Uranium Mill Tailings Radiation Control Act.

The EPA has entered into a Federal Facility Compliance Agreement with RFP and the State of Colorado, under RCRA and CERCLA. This may give EPA power of review, if not approval, for any action involved in the free release of property for RFP. The fact that RFP is a National Priorities List (NPL) Site coming under EPA review for CERCLA cleanup issues strengthens this hypothesis.

Uniform cleanup standards for radiologically contaminated federal facilities are in the formative stages of rule-making at EPA, but could be proposed as soon as early 1994. They would cover residual radioactivity and other types of contamination as well. The first part of EPA's upcoming proposal will deal with actual cleanup, and the second part (proposed approximately six months later) will pertain to management of removed waste. (BNA, April 16, 1993)

Along with EPA, NRC has regulatory responsibility in the radiological cleanup area. However, EPA in some sense has broader regulatory authority. EPA's generally applicable standards would cover not only NRC licensees, but also DOE and some DoD facilities. NRC is responsible only for the development of standards for its licensees. Both agencies have signed a memorandum of understanding stipulating that if EPA determines NRC standards for cleanup are protective of public health, then NRC licensees will be regulated by those standards. EPA is not only concerned with the cleanup but what is done with the waste after it is removed and whether any material may be reused. (BNA, April 16, 1993)

\subsection{Nuclear Regulatory Commission Position}

On July 3, 1990, the NRC adopted a policy statement on Below Regulatory Concern (BRC). This policy established a framework for NRC to approve exemptions from some or all regulatory controls for material involving small quantities of radioactive material. "The recycling of slightly contaminated equipment and materials" is one of the practices addressed in the BRC policy for which exemptions may be granted.

The BRC policy states that the average dose to individuals should be less than $10 \mathrm{mrem} / \mathrm{yr}$. for exempted practices. In addition, an interim dose criterion of $1 \mathrm{mrem} / \mathrm{yr}$. average annual dose to individuals has been established for those practices involving widespread distribution of radioactive materials in items such as consumer products or recycled material and equipment. (NRC, 1990) A collective dose limit of 1000 person-rem/year was also established for an exempted practice.

At the present time, NRC has placed the BRC policy on hold and has assembled a task force to reevaluate the policy. Surface contamination limits used for the termination of licenses for nuclear facilities are considered inadequate and work is in progress to develop general criteria for the unrestricted release of components. (DOE, August 1991) 
Recently, the need for generic NRC decommissioning standards was recommended at a workshop held by NRC. Participants agreed that NCR should develop generic rather than site-specific standards for decommissioning sites. Currently, NRC is using a site-by-site approach for cleaning up and decommissioning facilities licensed by NRC and "agreement states," including Colorado. (BNA, May 14, 1993)

Generic standards would provide radiological criteria on "how clean is clean enough" in decommissioning sites and releasing the property for unrestricted use. Participants also agreed that flexibility for site-specific standards and efficient implementation should be built into the generic standards. This guidance was the result of public workshops NRC held around the U.S. on its enhanced participation rule-making process on establishing criteria for residual contamination at site. (BNA, May 14, 1993) criteria:

NRC so far has identified four distinct alternatives for the radiological

- Risk limits, where a limiting value is selected and criteria are established below the limit using practical considerations

- Risk goal, where a goal is selected and practical considerations are used to establish criteria as close to the goal as possible

- Best effort, where the technology for decontamination considered to be the best vehicle is applied

- Return to existing background, where the decontamination would continue until the radiological conditions were the same as those that existed before the licensed activities

NRC hopes to have a final rule by May 1995. NRC has set up an electronic bulletin board to provide information and accept comments on the enhanced participation rule-making process. Information on how to connect to the bulletin board can be obtained by calling (301) 492-3999 or (301) 492-3790 weekdays between 10:00 a.m. and 3:00 p.m. (BNA, May 14, 1993)

\subsection{State of Colorado}

The recycling and eventual release of DOE's equipment from D\&D installations is not only regulated in the federal sector. If DOE transfers the property to a contractor for treatment on private land in an Agreement State and the contractor releases the property, the state has regulatory authority for the treatment process and the release of the property. As of 1991, 29 states, including Colorado, have entered into an agreement with NRC under subsection 274 (b) of the Atomic Energy Act of 1954, as amended, to regulate radioactive material. (DOE, August 1991)

DOE facilities that may have large quantities of equipment are in Agreement States such as New Mexico, Tennessee, Washington, and Colorado. RFP has a Federal Facilities Agreement in place with the state of Colorado, which may give the state power of review, if not approval, of actions associated with the decontamination and free-release of radiologically contaminated equipment. As of 1991, the state regulators had not dealt with a case involving volumetrically contaminated equipment. (DOE, August 1991) 


\subsection{Rocky Flats Plant Guidance Interpretations}

Institutional controls at RFP appear to reflect overly cautious interpretations of current DOE guidance. Also, current site policies are sometimes inconsistent with one another.

RFP institutional requirements and procedures for free-release of equipment are as follows:

- Health and Safety Plan (HSP) 18.10-Release of Property/Waste for Conditional and Unrestricted Use

- Radiological Engineering (RE) 1003-Radiological Evaluation for Unrestricted Release of Property

- Radiological Operational Instructions (ROI) 3.02-Survey Requirements for Conditional and Unrestricted Use

At RFP, a Property Release Moratorium Phase II has been implemented.

Phase II provides for a mobile team at RFP and RFP facilities to monitor items and equipment for unrestricted release. This mobile team will survey materials, property, and equipment in accordance with RFP policy, including HSP 18.10 and ROI 3.02, for unrestricted release.

Beryllium contamination of the equipment in Building 865 was discussed with Mike Richen of Industrial Hygiene. Mr. Richen was very helpful in describing the problems encountered in decontamination of the equipment and the associated liabilities with unrestricted release. The problems stem from the inability to check all the equipment surfaces to verify the beryllium limit of $25 \mu \mathrm{g} / \mathrm{ft}^{2}$ is met.

Requirements for unrestricted release of radiologically contaminated equipment from RFP was discussed with Gwen Aldrich, Radiological Engineering Section Manager for EG\&G. Mr. Aldrich described the same problems Mr. Richen described for beryllium contamination. Mr. Aldrich also stated that EG\&G requirements for unrestricted release where based on the assumption that decontamination has been conducted and levels of contamination meeting the allowable limits have been achieved. According to Mr. Aldrich, RFP's practice for verification of decontamination requires a $100 \%$ surface survey, which in turn requires total disassembly of equipment.

RE 1003 does not specifically state that $100 \%$ of the surface area must be surveyed. Provisions for specific exemptions are contained in the RE 1003. On request and approval by the Assistant General Manager, Plant Safety and Security, the release is to be processed through the DOE operations office. Requests for exceptions shall demonstrate a clear need for an exception and detail compliance with the basic dose limits set forth in DOE Order 5400.5.

HSP 18.10-Release of Property/Waste for Restricted and Unrestricted Use, defines requirements and criteria established by 40 CFR part 261, DOE Radiological Control Manual; DOE Order 5400.5, Radiation Protection of the Public and the Environment; DOE Order 5480.11, Radiation Protection of Occupation Workers; and the Plant Policy 13-3 and Property Removal Permits for the restricted and unrestricted release of property.

Unrestricted Release is defined in Section 3.16 of HSP 18.10 as "release of property from anywhere within the Plant Boundary without restriction on future 
movement or disposal, in accordance with guidelines and requirements of DOE Orders 5400.5 and 5480.11, DOE Radiological Control Manual and HSP 18.10."

According to HSP 18.10, Section 4.4, RE is responsible for establishing alternate, non-routine, and/or special methods to meet release criteria established by DOE. This is accomplished and documented using RE 1003, Radiological Evaluation for Unrestricted Release of Property. Additionally, the RE classifies buildings or areas as Radioactive Material Management Area (RMMAs), Radiological Controlled Areas (RCAs), or uncontrolled areas, maintains the building evaluation files and current building lists, and performs property release evaluations.

RO as defined in HSP 18.10, Section 4.5, performs initial property release evaluations in accordance with ROI 3.02, Survey Requirements for Conditional and Unrestricted Use; performs radiological surveys as required for property transfers or releases in accordance with ROI 3.02; and refers property release to RE when the property meets certain criteria listed in ROI 3.02. The unrestricted property release/transfer procedure and conditional property release/transfer procedure are contained in HSP 18.10, Section 5.1 and Section 5.2, respectively.

References cited in HSP 18.10 and pertaining to disposition of materials are as follows:

- RE 1003-Radiological Evaluation for Unrestricted Release of Property

- 40 CFR 261-Material Destined for a Landfill, Offsite Disposal, or Treatment Prior to Disposal

- ROI 3.02-Survey Requirements for Conditional and Unrestricted Use

- ROI 3.1-Performance of Surface Contamination Surveys

- DOE Order 5400.5-Radiation Protection of the Public and Environment

- DOE Order 5480.11-Radiation Protection of Occupational Workers

- 40 CFR 261-Identification and Listing of Hazardous Wastes

The impacts of the $100 \%$ surface survey practice at RFP must be

resolved prior to attempting free release. Cost estimates presented here are based on the ability to ensure decontamination compliance without $100 \%$ surface survey. In turn, the level of decontamination, disassembly and exposure are based on equipment type. Some equipment may require minimal decontamination/disassembly and survey to ensure compliance with regulatory standards for contaminant levels. Other equipment may be too complex, and require total disassembly and surface survey to ensure compliance. RFP procedures and policies governing the level of decontamination and verification need to be revised to allow for case-by-case evaluation of equipment for release, as indicated in current and proposed DOE guidance.

\subsection{Regulations for the Transportation of Radioactive Materials}

The policies and regulations for the safe transport of radioactive materials through interstate and foreign commerce by all modes of travel except postal shipments, falls under the jurisdiction of the Department of Transportation Act and the Transportation Safety Act of 1974 and is regulated by the U.S. DOT. Shipments within a single state are subject to control by that state's transportation agency. In addition, under the Atomic Energy Act, as amended, the NRC has the responsibility 
for safety in the possession and use, including transport, of by-product, source, and special nuclear materials. Since both agencies possesses statutory authority to regulate transport of radioactive materials, the NRC and DOT have a written Memorandum of Understanding (MOU) for regulating the transportation of radioactive materials. The MOU generally delineates the respective responsibilities of each agency so as to avoid overlap, duplication and/or conflicting regulatory standards. Table $3.7 \mathrm{a}$ lists the federal regulations for transporting radioactive materials.

Table 3.7a

Sources of Federal Regulations Regarding

Transportation of Radioactive Material

\begin{tabular}{|c|c|}
\hline \multicolumn{2}{|c|}{$\begin{array}{ll}\text { Title } 49 & \text { Department of Transportation's } \\
& \text { "Hazardous Materials Regulations," Parts 100-178 }\end{array}$} \\
\hline \multicolumn{2}{|r|}{ Main Headings } \\
\hline $\begin{array}{l}49 \text { CFR } 106 \\
49 \text { CFR } 107 \\
49 \text { CFR } 171 \\
49 \text { CFR } 172 \\
49 \text { CFR } 173 \\
49 \text { CFR } 174 \\
49 \text { CFR } 175 \\
49 \text { CFR } 176 \\
49 \text { CFR } 177 \\
49 \text { CFR } 178\end{array}$ & $\begin{array}{l}\text { Rulemaking Procedures } \\
\text { Hazardous Materials Program Procedures } \\
\text { General Information, Regulations and Definitions } \\
\text { Hazardous Materials Tables and } \\
\text { Hazardous Materials Communications Regulations } \\
\text { Shippers-General Requirements for } \\
\text { Shipments and Packagings } \\
\text { Carriage by Rail } \\
\text { Carriage by Aircraft } \\
\text { Carriage by Vessel } \\
\text { Carriage by Public Highway } \\
\text { Shipping Container Specifications }\end{array}$ \\
\hline \multicolumn{2}{|c|}{ U.S. Nuclear Regulatory Commission } \\
\hline 10 CFR 71 & $\begin{array}{l}\text { Packaging and Transportation of Radioactive Material } \\
\text { Note: Pursuant to } 10 \mathrm{CFR} 71.5 \text { [7], NRC licensee shippers } \\
\text { are directly subject to } 49 \mathrm{CFR} \text { shipper requirements. }\end{array}$ \\
\hline
\end{tabular}

The purpose of these regulations is to ensure the safety of transport workers, property, the environment, and the general public. The regulations provide for:

1. Containment of the material during handling and transport

2. Protection of persons form radiation emitted by the material

3. Dissipation of any excessive heat form thermal decay of the material

4. Prevention of accidental criticality if the radioactive material is also a fissile material

The foremost responsible party, the shipper, achieves these objectives through maintaining extensive operational controls for packaging containers. The packaging requirements are designed to be commensurate with the hazards of the radioactive material in relation to its type, quantity and form. The degree of container integrity required covers a continuum ranging from: (1) essentially no 
specific package requirements for specific radioactivity $<2.0 \mathrm{nCi} / \mathrm{g}$, deminimus level or Low Specific Activity (LSA); (2) minimal packaging, or Type A; (3) very stringent, high integrity packaging for Type B or "Highway Route Controlled Quantity." The NRC periodically publishes a directory of certificates of compliance for the radioactive materials package designs that have been approved.

In addition to requirements for packaging corresponding to activity of contents, the regulations contain a number of other requirements, including control of radiation during transport, warning labels, vehicle and storage limits, package markings, shipping paper requirements, contamination control and vehicle placards.

The radiation levels allowed during transport are summarized in Table 3.7b. Each package of radioactive material, unless excepted (i.e. (LSA), must be labeled on two opposite sides with one of the approval forms of the distinctive warning signs indicating radioactive contents. To control the radiation level of accumulations of multiple numbers of packages once in the transportation environment, the regulations require that the carrier maintain certain required separation distances between packages and other areas which are occupied by persons and photographic film. Unless excepted from marking (LSA) each completed radioactive materials package must be marked by the shipper with the following:

1. Applicable DOT package specification

2. Applicable NRC, DOE or IAEA Certificate Identification Number

3. Package exceeding $50 \mathrm{~kg}$ (110 lbs.) gross weight

4. Labeled LSA, Type A or B

5. Applicable DOT Proper Shipping Name and Identification Number (49 CFR 172.101)

Table 3.7b

Maximum Radiation Levels Limitations for Packaging and Transportation

Radiation level (dose) rate at any point on external surface of any package of radioactive material may not exceed:

A. $200 \mathrm{mrem} / \mathrm{h}$

B. $10 \mathrm{mrem} / \mathrm{h}$ at one $\mathrm{m}(3.3 \mathrm{ft}$.) (Transport Index may not exceed 10 ).

Unless the packages are consigned to a "Sole Use" or "Exclusive Use" transport vehicle (except aircraft) then the Maximum Radiation Levels may be:

(a) $1 \mathrm{mrem} / \mathrm{h}$ at the External Package Surface (closed transport vehicle)

(b) $200 \mathrm{mrem} / \mathrm{h}$ at external surface of vehicle

(c) $10 \mathrm{mrem} / \mathrm{h}$ at $2 \mathrm{~m}$ (6.6 ft. from lateral external surface of the vehicle)

(d) $2 \mathrm{mrem} / \mathrm{h}$ in any position of the vehicle which is occupied by a person. This provision does not apply to a private carrier whose personnel are under a radiation protection program and using a personnel monitoring device.

Additionally, each dispatch of radioactive material must be accompanied by a properly prepared shipping paper, containing the following required elements of information:

1. DOT proper shipping name (49 CFR 172.101)

2. Description of the physical and chemical form of the material (if not LSA) 
3. Shipper's certification

4. Activity in each package

5. Transport index assigned to each package

6. Name of each radionuclide

7. Category of label applied to each package

8. NRC, DOE, or IAEA Certificate Identification

9. DOT identification number from 49 CFR 171.101

Finally, DOT regulations mandate certain limits for the control of removable external (nonfixed) radioactive surface contamination (Table 3.7c) and for transport vehicles, with the exception of LSA materials, to be marked on all four sides with a DOT radioactive placard.

\section{Table 3.7c}

Contamination Limits for Removable Surface Contamination for Transport (49 CFR 173.443) (nCi/100 $\left.\mathrm{cm}^{2}\right)\left(\mathrm{dpm} / \mathrm{m} / 100 \mathrm{~cm}^{2}\right)$

\begin{tabular}{|lcc|}
\hline & \multicolumn{2}{c|}{ Package Wipe Sample Limits } \\
\cline { 2 - 3 } Contaminant & nonexclusive use & exclusive use \\
\hline Beta-gamma emitting radionuclides; all & & \\
radionuclides with half-lives less than 10 & & 10 \\
days; uranium and thorium and their & 1 & $(22,000)$ \\
daughters when contained in ores or & $(220)$ & 1 \\
concentrates & 0.1 & $(2200)$ \\
& $(220)$ & \\
All other alpha-emitting radionuclides & &
\end{tabular}

When these higher wipe sample limits are applied, the transport vehicle must be surveyed after each use. Vehicle may not be placed in service until the surfaces are within the limits for nonexclusive use packages. 


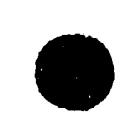

- 


\section{References}

Code of Federal Regulations:

10 CFR Part 834, "Radiation Protection of the Public and the Environment; Proposed Rule." Federal Register, Thursday March 25, 1993, Part II.

40 CFR 192, "EPA Standards For Protection Against Uranium Mill Tailings."

40 CFR 261, "Identification and Listing of Hazardous Wastes."

41 CFR 101, "Federal Property Management Regulations."

48 CFR, Subpart 45.6, "Federal Acquisition Regulation: Reporting,

Redistribution and Disposal of Contractor Inventory."

Rocky Flats Documents:

A Decontamination and Decommissioning Plan (D\&D) for the Rocky Flats Plant (RFP). DOE-Rocky Flats Office, Environmental Restoration

Division. Prepared by KMI Services (Bearden). (Draft.)

December 23, 1992.

Mission Transition Program Management Plan. EG\&G Rocky Flats. October 1, 1992.

Personal Communication with Gwen Aldrich, Radiological Engineering, EG\&G. Re: Moratorium on Release, RFP. June 18, 1993.

Projected Surplus Non-Plutonium Defense Production Facilities Element. Appendix A-Z. Rocky Flats Plant. Rev. 7 (Draft). October 1, 1992.

Radiological Engineering 1003, "Radiological Evaluation for Unrestricted Release of Property."

Radiological Operational Instructions 3.02, "Survey Requirements for Conditional and Unrestricted Use."

Radiological Operational Instructions 3.1, "Performance of Surface Contamination Surveys."

Rocky Flats Field Summary Report. Prepared by Theta Technclogies, Inc., April 5, 1993

Other References:

BNA Environmental Reporter, "Current Developments," April 16, 1993. "Federal Facilities. Cleanup Standards in Early Development Stage For Radioactivity and Other Contamination, EPA says."

BNA Environmental Reporter, "Current Developments," May 14, 1993. "Radioactive Waste. Generic NRC Decommissioning Standards Recommended by Diverse Workshop Attendees."

IAEA, 1988. Factors Relevant to The Recycling or Reuse of Components Arising from the Decommissioning and Refurbishment of Nuclear Facilities. Technical Report Series No. 293.

Grella, Alfred W. 1986. Radioactive Waste Technology Chapter 10 "Regulation of Nuclear Waste Transportation," pp. 407-420. 
References (continued)

U.S. DOE Order 5400.5, "Radiological Protection of Public and the Environment."

U.S. DOE Order 5480.11, "Radiation Protection of Occupational Workers."

U.S. DOE, August 1991. Draft White Paper, Radioactive Scrap Metal Recycling: A DOE Assessment. Prepared for the U.S. Department of Energy Office of Environmental Restoration by the Office of Technical Service/Weston and H\&R, Germantown, MD.

Vira, J. and M. Yasui, "International Comparisons of Decommissioning Cost Estimates: Reasons for Discrepancies." From Decommissioning Polices For Nuclear Facilities: Proceedings of an International Seminar. Paris 2-4 October 1991. Nuclear Energy Agency, Organization for Economic Co-operation and Development (OECD), Paris, 1992 


\section{A.1 Baseline Alternative Landfill Disposal}

Each cost estimation cossists of the addition of nus summation componeats which sumed an iadividual cost for each piece of equipment considered; added 10 - third composent - ose time "fised managemeal cost". The sumbation composevts are: 1) equipmeat with bydraulic fuid. cost of drain and nust and 2) applicable individual cost for resovah tmasporation, asd dispons. These are delineated by post scripts is the equation below. Inputs to lbese equations

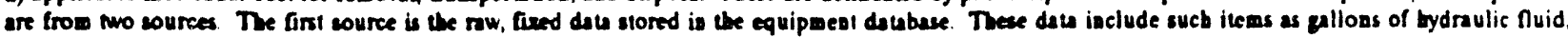

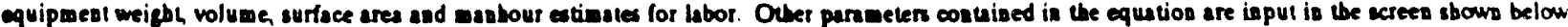
Resule for applying these equations are presented is Appeadix B.

For Connecial Dimponal:

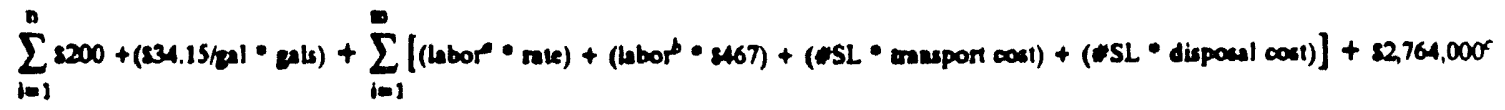

Enaple lien 72. Bullard Vertical Tumel Luthe, Crew Type D, $* S L=22$

$$
\left.2000+(234.15 / 20)^{\bullet} 130\right)+[(24 \cdot 81,472)+(60 \cdot 8467)+(22 \cdot 87,650)+(22 \cdot 8512,000)]
$$

Inew 72 Disponal Cont onty $=\$ 11,211,217.50$

For Govennent Dinponel:

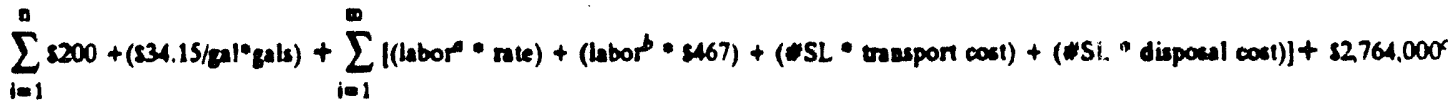

Enmple liem 72: Bullard Vertical Turret Lathe, Crew Type D. $* S L=22$

$8200+(834.15 / 901 \cdot 130)+[(24 \cdot 31,472)+(60 \cdot 8467)+(22 \cdot 87,650)+(22 \cdot 812800)]$

Ites 72 Disposal Cost osty $=8112977.50$

Nore:

- E equipeest witb tydralic nuid

- all cober cquipecent

- hbor nete loe noconl an (ie ABC or D)

- SL oumber of meatand contaiber vilized

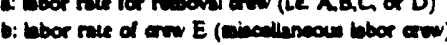

$a$ fond menaposent price for cature option

The Multipliet Dau Base Screen is included below:

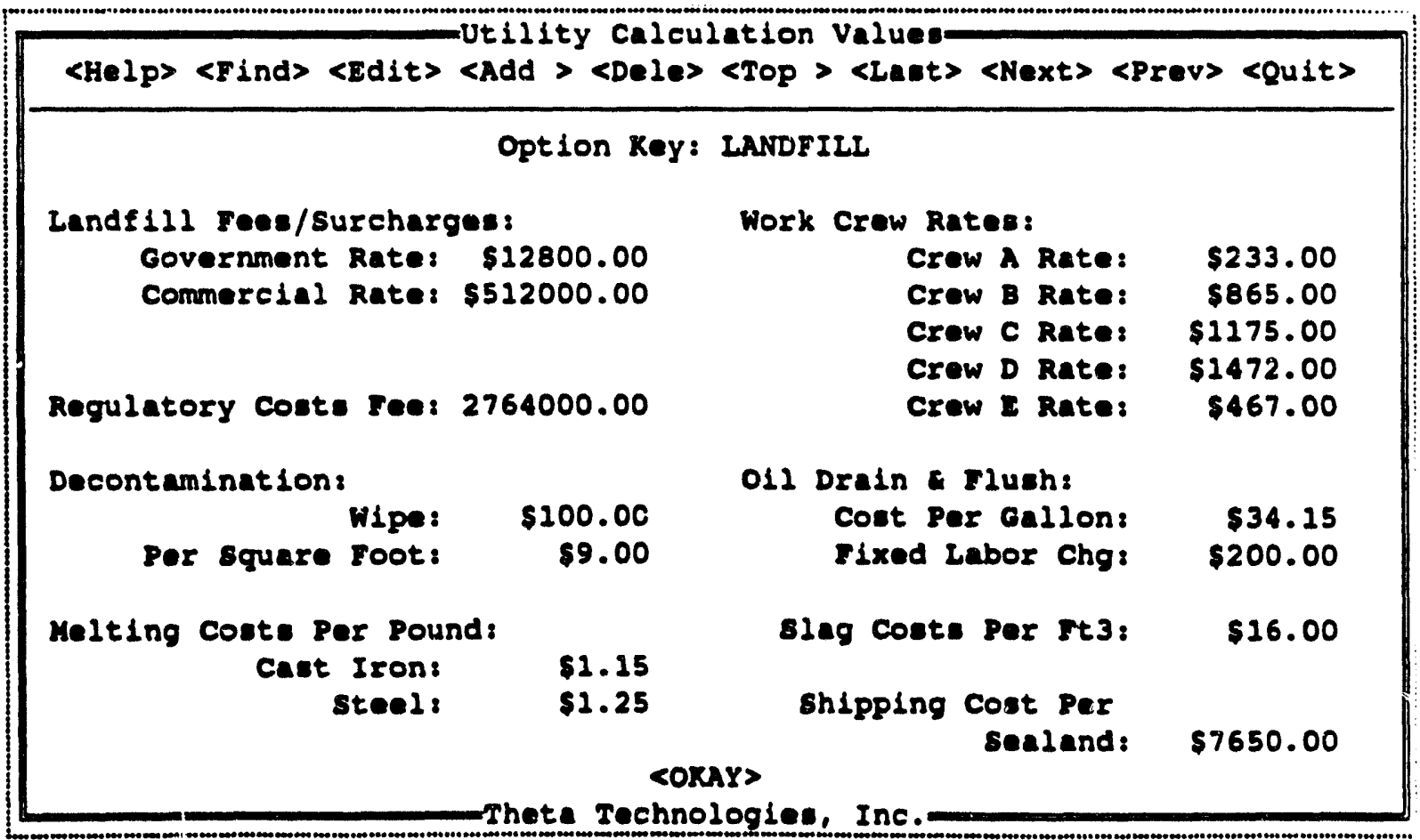




\section{A.2 Recycle Metal}

Each cost estimation consists of the addition of no sumention cosposents which sumered as individual cost for each piece of equipmeal considered. added

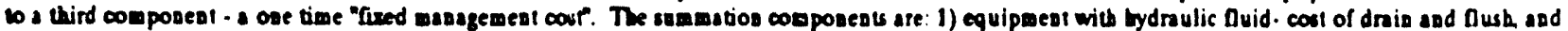

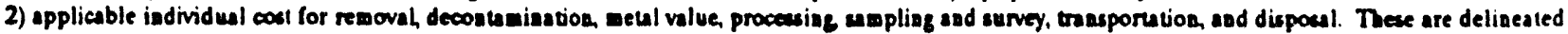
by post ceripts is the equations below. Inpus to these equations are fros wo cources. The first cource is be raw, fined data stored is the equipment

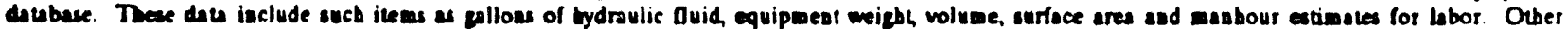

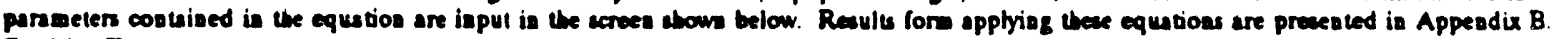

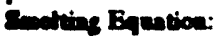

$\stackrel{2}{2} 200+(234.15 / 2 a l \cdot(2 a)+$

- IProcarsing Costl I Meul Value I

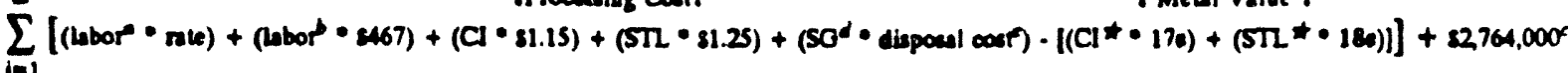

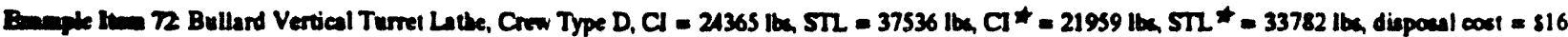
$200+(234.15 / 201 \cdot 130)+[(24 \cdot 81472)+(60 \cdot 8467)+(24365 \cdot 81.15)+(37536 \cdot 81.25)+(16 \cdot 816.00) \cdot[(21959 \cdot 170)+(33782 \cdot 184)]]$ Itev 72 Snelting Cost onhy $=3133,403.21$

Sop Epation

s

$\sum 200+(834.15 / 2 a l \cdot 2 a l s)+$

in Decos \& Cosi iMetal Veluet

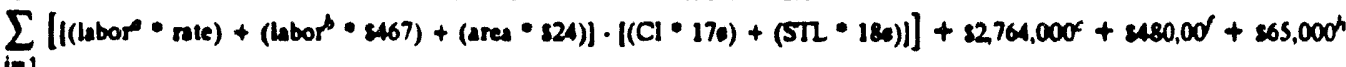

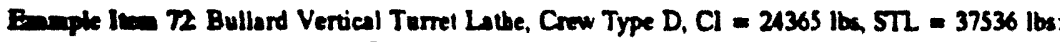

$8200+(234.15 / 291 \cdot 130)+[(24 \cdot 81472)+(60 \cdot 8467)+(166 \cdot 824)] \cdot[(24363 \cdot 170)+(37536 \cdot 184)]]$

Item 72 Semping Cost onty $=861,07297$

Nore:

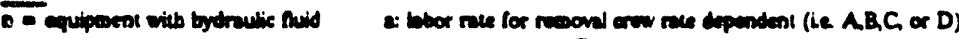

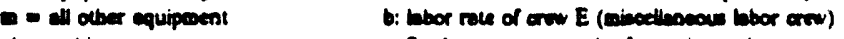

- metal ingor

SOd ang in arbic feer

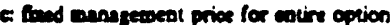

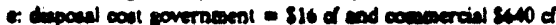

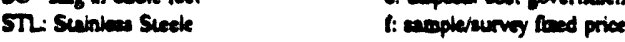

Cl: Cans Iros

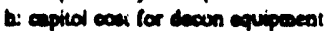

The Multiplier Dat Base Screes is included below

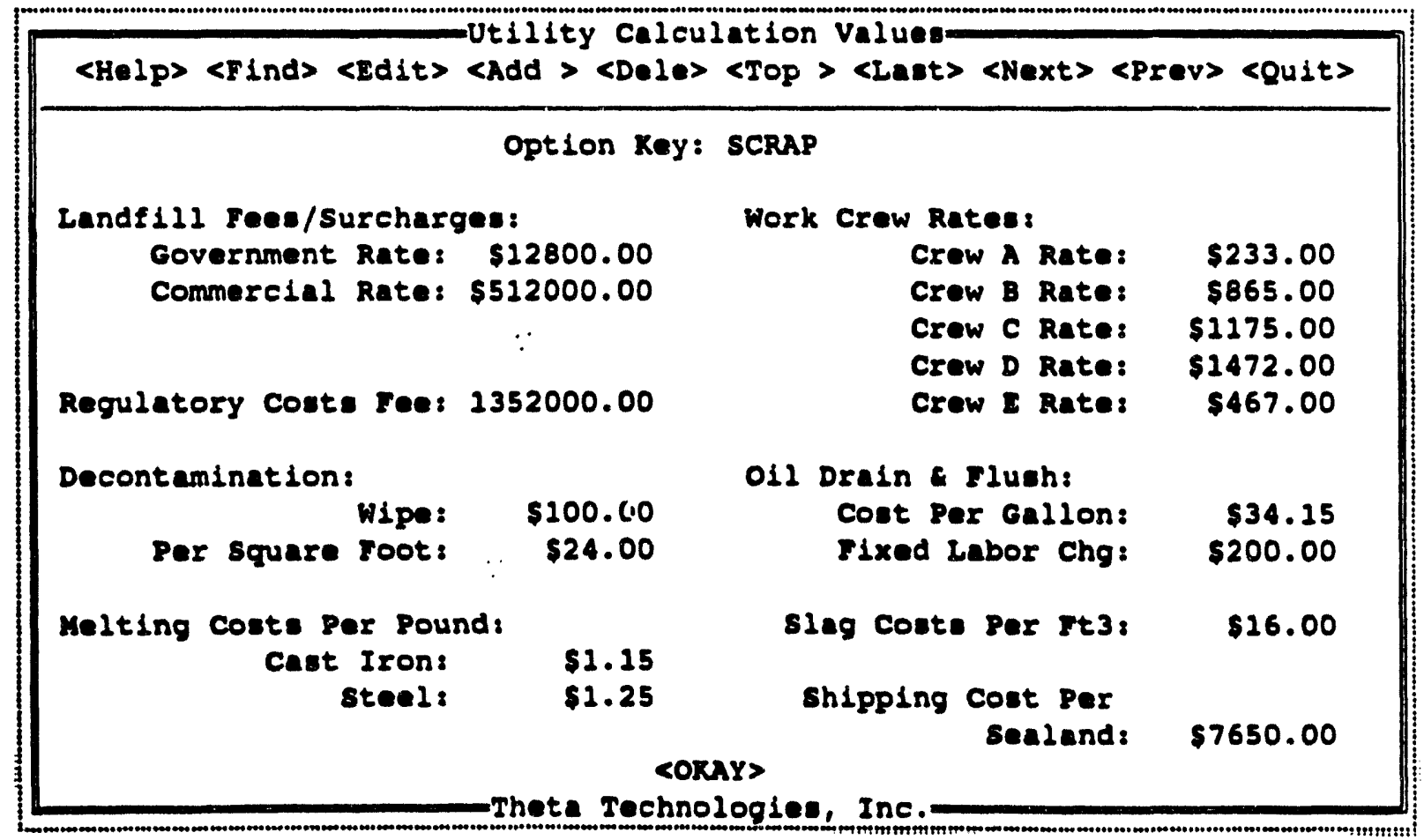




\section{A.3 Reuse Within the Governmental Sector}

Each cost estination consists of the addition of two sumestion components which sumed an individual cost for eacb piece of equipmenf considered, added wa third cosposent - ose time "fired managemeat cost". The summation cosposeats are: 1) equipmeat with bydraulic fluid-cost of draia and flush, and 2) applicable individual cost for revoval decontaniantion, trasportation, and umpling and survey. These are deliseated by post scripts in the equations below. Laputs to these equations are tros nwo sources. The first cource is the nw, fired dau stored in the equipeseat database. These dala include such

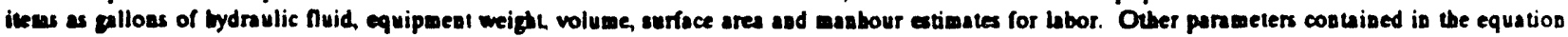
are input in the cerees stow below. Results form applyibg these equations are presented is Appeadix B.

Oromianced Epation

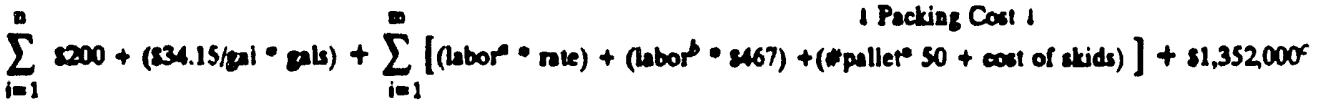

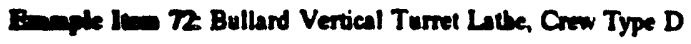

$8200+(834.15 / 901 \cdot 130)+[(24 \cdot 81,472)+(60 \cdot 8467)+(812100)]$

lien 72 Trenter Cost only $=820,087.50$

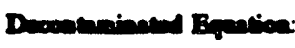

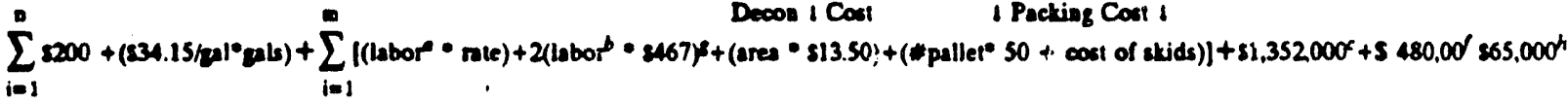

Enare 72 Bullard Verical Turnet Latbe, Crew Type D

$8200+\left(234.15 / \mathrm{pl}^{*} \cdot 130\right)+[(24 \cdot 81.472)+2(60 \cdot 8467)+(166 \cdot 13.50)+(812.100)]$

Iver 72 Trester Cost oaly $=\$ 110,348.50$

Noce:

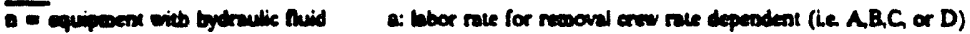

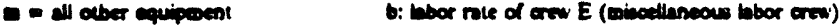

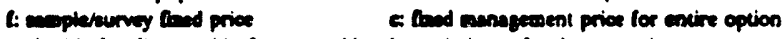

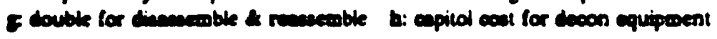

Te Multiplier Dat Base Senese is included below:

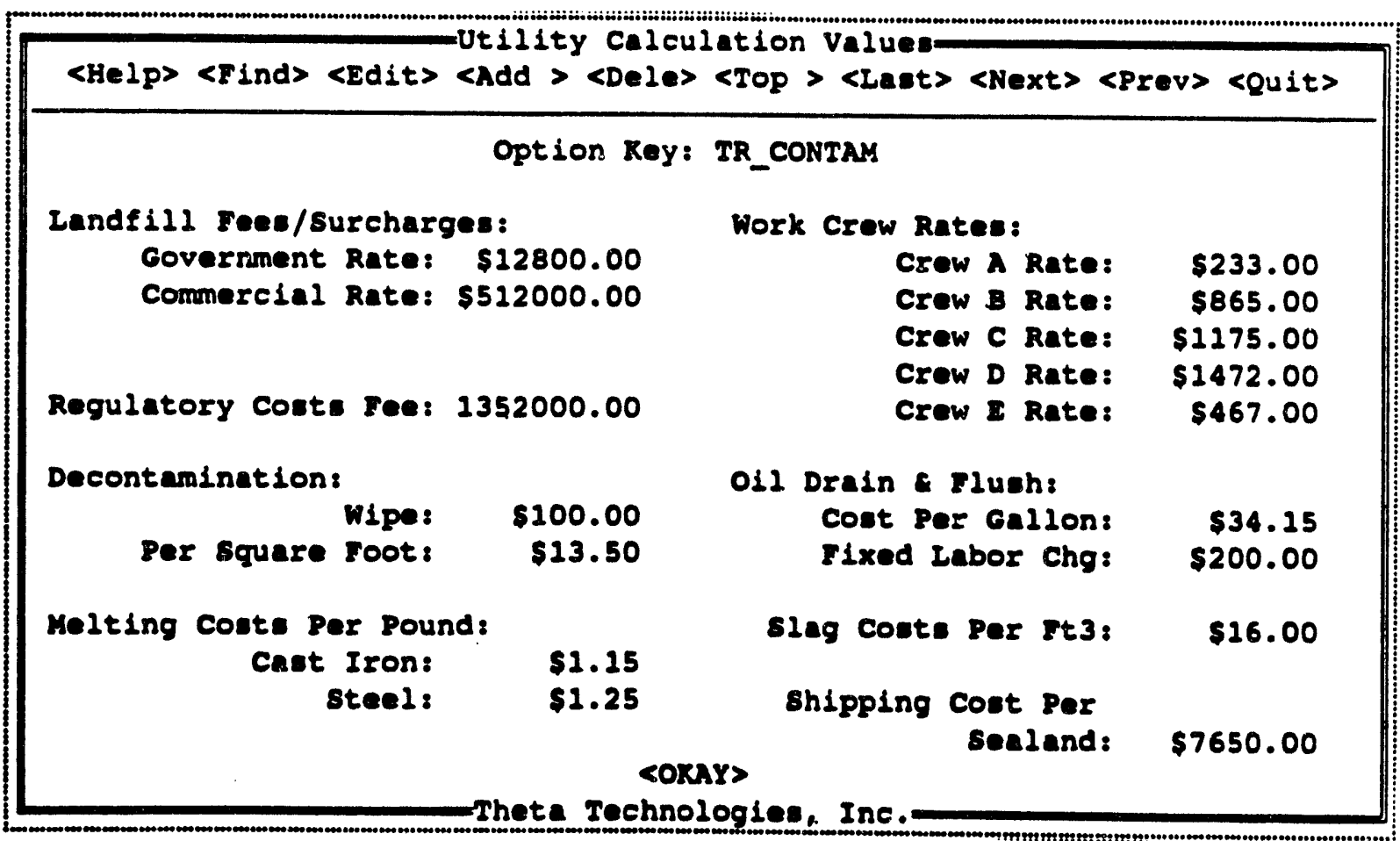




\section{A4 Unrestricted Release To Non Government Organizations}

Ench cost estimation cossists of the addition of two summation composeats whicb suened an iadividual cost for each piece of equipment considered; added 10. third component - ane time "fixed anagemeat cost". The summation componeats are: 1) equipment with bydraulic nuid. cost of drain and nusb. and

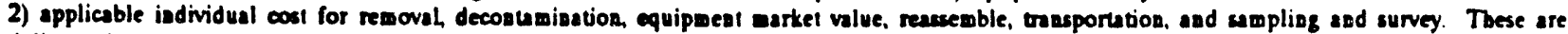
deliseated by post scripts in the equations below. Isputs to these equations are from no sources. The first cource is the raw, fired dat stored in the

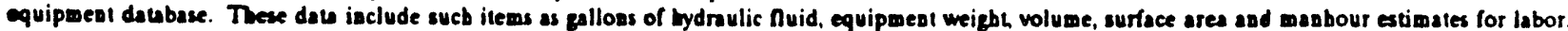
Orher parameten contuiaed in the equation are iapul is the ecrees stow below. Results form applying these equations are presented is Appendix B.

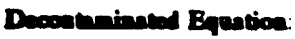

D. Decos 1 Cost 1 Packing Cost 1

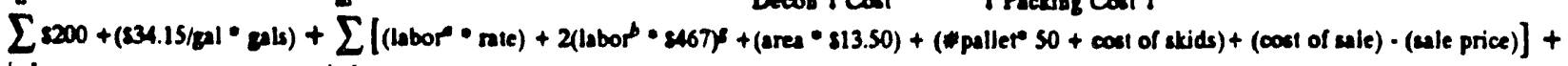
(a) $=1$

$81,352,000+\$ 480,00+865,000^{h}$

Breple 72 Bulland Vertical Turret Lethe, Crow Type D

$\left.2200+(834.15 / 2)^{+} 130\right)+[(24 \cdot 81,472)+2(60 \cdot 8467)+(166 \cdot 513.50)+(812,100)+(84284)-(823800)]$

Inean 72 Unrestricted Release Cost oaly $=\$ 117,764.5$

Note:

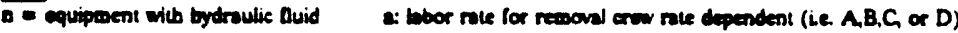

- Ell ober cauipenent

f: eamplehourvey fraed price

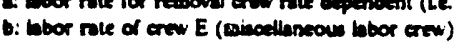

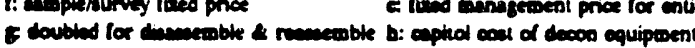

The Multiplier Dat Base Screen is included below:

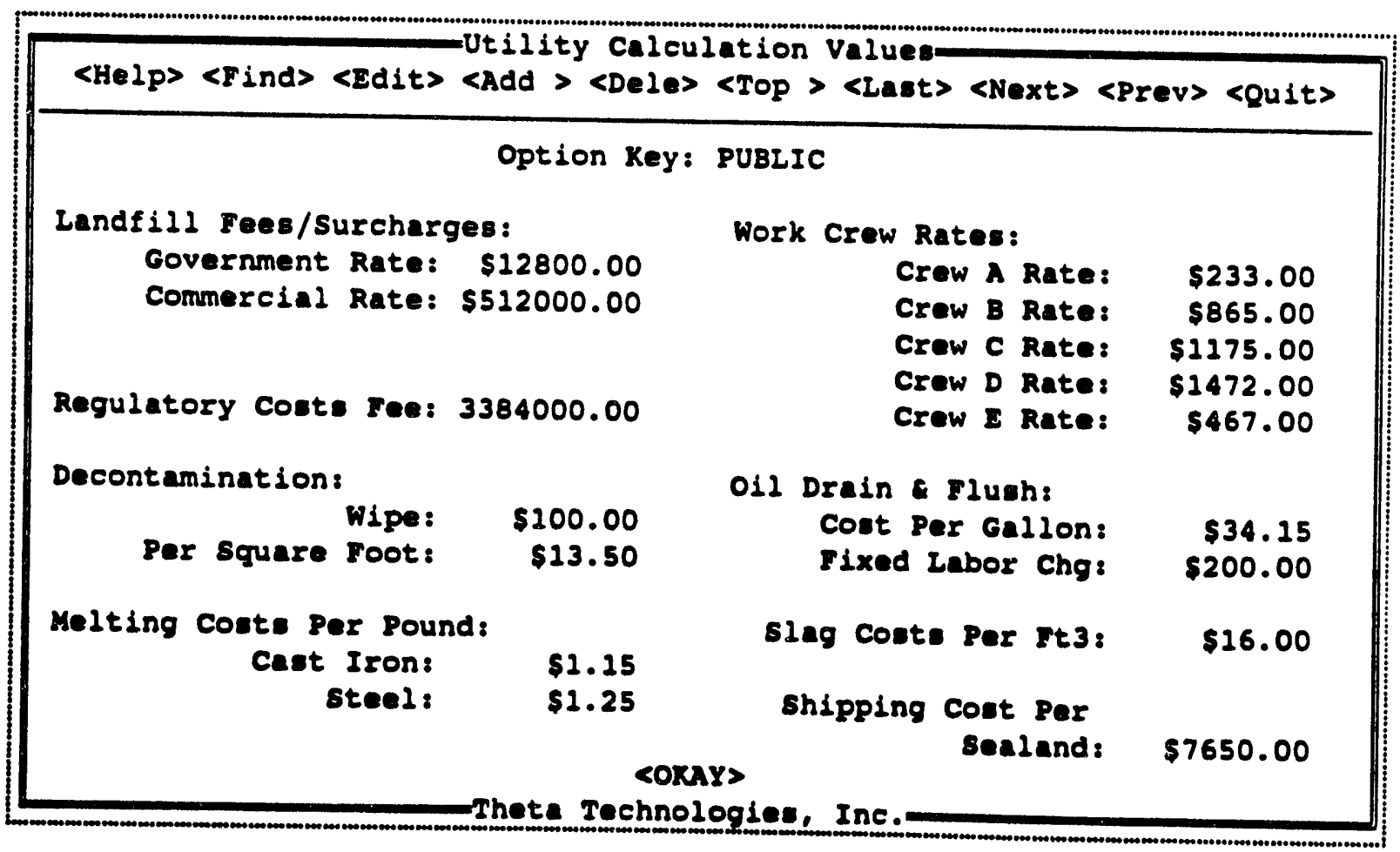




\section{B.1 General Equipment Data}

Rocky Flats General Equipment Data includes pertinent information for each piece of equipment. This information includes: Item number, manufacturer, model and serial numbers, room number, approximate size in cubic feet, map location, Rocky Flats Plant property number, purchase price, and condition code. The condition codes for the equipment were evaluated and assigned based on the procedure outlined in 41 CFR 101. The condition codes as found in 41 CFR 10143.4803 are included below.

$\$ 101-43.4801$

41 CFR Ch. 101 (7-1-90 Edition)

(e) The appropriate disposal condition code from the table below shall be assigned to each item record, report, or listing of excess personal property:

\begin{tabular}{|c|c|c|}
\hline $\begin{array}{c}\text { Disposal Condition } \\
\text { Code } \\
\end{array}$ & Brief Definition & Expanded Definition \\
\hline 1 & Unused-good $\ldots \ldots$ & $\begin{array}{l}\text { Unused property that is usable without repairs } \\
\text { and identical or interchangeable with new items } \\
\text { from normal supply sources. }\end{array}$ \\
\hline 2 & Unused-fair ... & $\begin{array}{l}\text { Unused property that is usable without repairs, } \\
\text { but is deteriorated or damaged to the extent that } \\
\text { utility is somewhat impaired. }\end{array}$ \\
\hline 3 & Unused-poor & $\begin{array}{l}\text { Unused property that is usable without repairs, } \\
\text { but is considerably deteriorated or damaged. } \\
\text { Enough utility remains to classify the property } \\
\text { better than salvage. }\end{array}$ \\
\hline 4 & Used-good ........ & $\begin{array}{l}\text { Used property that is usable without repairs and } \\
\text { most of its useful life remains. }\end{array}$ \\
\hline 5 & Used-fair. & $\begin{array}{l}\text { Used property that is usable without repairs, but } \\
\text { is somewhat worn or deteriorated and may soon } \\
\text { require repairs. }\end{array}$ \\
\hline 6 & Used-poor & $\begin{array}{l}\text { Used property that may be used without repairs, } \\
\text { but is considerably wom or deteriorated to the } \\
\text { degree that remaining utility is limited or major } \\
\text { repairs will soon be required. }\end{array}$ \\
\hline 7 & Repairs required-good . . . . . . . . & $\begin{array}{l}\text { Required repairs are minor and should not } \\
\text { exceed } 15 \text { percent of original acquisition cost. }\end{array}$ \\
\hline 8 & Repairs required-fair . . . . . . . . & $\begin{array}{l}\text { Required repairs are considerable and are } \\
\text { eatimated to range from } 16 \text { percent to } 40 \text { percent } \\
\text { of original acquisition cost. }\end{array}$ \\
\hline 9 & Repairs required-poor . . . . . . . . & $\begin{array}{l}\text { Required repairs are major because property is } \\
\text { badly damaged, worn, or deteriorated, and are } \\
\text { estimated to range from } 41 \text { percent to } 65 \text { percent } \\
\text { of original acquisition cost. }\end{array}$ \\
\hline
\end{tabular}




\begin{tabular}{|c|c|c|}
\hline $\begin{array}{l}\text { Disposal Condition } \\
\text { Code }\end{array}$ & Brief Definition & Expanded Definition \\
\hline $\mathbf{X}$ & Salvage $\ldots \ldots \ldots \ldots \ldots \ldots$ & $\begin{array}{l}\text { Property has some value in excess of its basic } \\
\text { material content, but repair or rehabilitation to } \\
\text { use for the originally intended purpose is clearly } \\
\text { impractical. Repair for any use would exceed } \\
65 \text { percent of the original acquisition cost. }\end{array}$ \\
\hline $\mathbf{S}$ & Scrap $\ldots \ldots \ldots \ldots \ldots \ldots$ & $\begin{array}{l}\text { Material that has no value except for its basic } \\
\text { material content. }\end{array}$ \\
\hline
\end{tabular}

(f) In addition to the appropriate disposal condition code from the table in paragraph (e) of this section, each item record, report, or listing of Department of Defense excess personal property shall also contain the appropriate supply condition code assigned before or at the time the item was declared excess, except item records, reports, or listings of contractor inventory when a determination is made that inclusion of the supply condition code is impractical. When available, civil agencies shall include the appropriate supply condition code in each item record, report, or listing of excess personal property. These codes, which provide additional material condition information for screening purposes, follow:

\begin{tabular}{|c|c|c|}
\hline $\begin{array}{l}\text { Supply Condition } \\
\text { Code }\end{array}$ & Brief Definition & Expanded Definition \\
\hline $\mathbf{A}$ & $\begin{array}{l}\text { Serviceable (issuable without } \\
\text { qualification) } \ldots \ldots \ldots \ldots \ldots \ldots\end{array}$ & $\begin{array}{l}\text { New, used, repaired, or reconditioned material } \\
\text { that is serviceable and issuable to all customers } \\
\text { without limitation or restriction. Includes } \\
\text { material with more than six months shelf-life } \\
\text { remaining. }\end{array}$ \\
\hline B & $\begin{array}{l}\text { Serviceable (issuable with } \\
\text { qualification) } \ldots \ldots \ldots \ldots \ldots \ldots\end{array}$ & $\begin{array}{l}\text { New, used, repaired, or reconditioned material } \\
\text { that is serviceable and issuable for its intended } \\
\text { purpose but is restricted from issue to specific } \\
\text { units, activities, or geographical areas by reason } \\
\text { of its limited usefulness or short service-life } \\
\text { expectancy. Includes material with three } \\
\text { through six months shelf-life remaining. }\end{array}$ \\
\hline $\mathbf{C}$ & Serviceable (priority issued) & $\begin{array}{l}\text { Ilems that are serviceable and issuable to } \\
\text { selected customers, but must be issued before } \\
\text { Conditions A and B material to avoid loss as a } \\
\text { usable asset. Includes material with less than } \\
\text { three months shelf-life remaining. }\end{array}$ \\
\hline D & Serviceable (test/modification) . . . . . . & $\begin{array}{l}\text { Serviceable material that requires test, } \\
\text { alteration, modification, conversion, or } \\
\text { disassembly. (This does not include items that } \\
\text { must be inspected or tested immediately before } \\
\text { issue.) }\end{array}$ \\
\hline $\mathbf{E}$ & Unserviceable (limited restoration) . . . . & $\begin{array}{l}\text { Material that involves only limited expense or } \\
\text { effort to restore to serviceable condition and that } \\
\text { is accomplished in the storage activity where the } \\
\text { stock is located. }\end{array}$ \\
\hline
\end{tabular}




\begin{tabular}{|c|c|c|}
\hline $\begin{array}{l}\text { Supply Condition } \\
\text { Code }\end{array}$ & Brief Definition & Expanded Definition \\
\hline $\mathbf{F}$ & Unserviceable (reparable) $\ldots \ldots \ldots$ & $\begin{array}{l}\text { Economically reparable mate ial that requires } \\
\text { repair, overhaul, or reconditioning, including } \\
\text { reparable items which are radioactively } \\
\text { contaminated. }\end{array}$ \\
\hline G & Unserviceable (incomplete) . . . . . . . . & $\begin{array}{l}\text { Material requiring additional parts or } \\
\text { components to complete the end item before } \\
\text { issue. }\end{array}$ \\
\hline $\mathbf{H}$ & Unserviceable (condemned) $\ldots \ldots \ldots$ & $\begin{array}{l}\text { Material that has been determined to be } \\
\text { unserviceable and does not meet repair criteria, } \\
\text { including condemned items that are radioactively } \\
\text { contaminated. }\end{array}$ \\
\hline $\mathbf{s}$ & Unserviceable (scrap) $\ldots \ldots \ldots \ldots \ldots$ & $\begin{array}{l}\text { Material that has no value except for its basic } \\
\text { material content. No stock will be recorded as } \\
\text { onhand in Condition Code S. This code is used } \\
\text { only on transactions involving shipments to } \\
\text { DPDOs. Material will not be transferred to } \\
\text { Condition Code S before being turned in to } \\
\text { PDOs if material is recorded in Condition Code } \\
\text { A through } H \text { at the time material is determined } \\
\text { excess. Material identified by NSN will not be } \\
\text { identified by this Condition Code. }\end{array}$ \\
\hline
\end{tabular}

[30 FR 5823, Apr. 27, 1965. Redesignated at 42 FR 40849, Aug. 12, 1977, and amended at 45 FR 28113, Apr. 28, 1980; 47 FR 8192, Feb. 25, 1982; 47 FR 15797, Apr. 13, 1982; 53 FR 16103, May 5, 1988] 
Rocky Flats Equipment Dato

Item Monufacturer

2 Mikon

Description

Camere

3 Polaroid

4 Vickers

5 Drusch Lomb

6 Leco

7 vilson

8 Buehler

9 witson

10 Theta

11 Automet

12 Leco

13 Mewage

16 Riehte

15 Clark Instr.

16 Wil son/Rockwel I

17

18 Jarrett

19 Leco

20 ouchler

21

22

23 Duehler

26 Instron

25 Buchler

26

27 MTs

28 mTs

29 Buchler

30 Buehter

Metallogreph

Dilatometer

Hoods (2 each) Abresinet sew

Test Machine

Test Machine

Model Mo./Serial Mo.

cubic

Mep. RFP Property Purchase

Location Munber

Price Condition

Cyare and Light Table

mite lend

102

Projection Microscope

102

Research II $w /$ Xenon 450

Microhardness Tester

Model 300

Model mo/serial 1979

Microhardhess Tester

Micromet 3

Microhardhess Tester

Model mo/serial 1173

Dilatronic Model $1600 \mathrm{C}$

Automet/Evromet Poll lsher

Dismond sans (2 eech)

Veri/Cut Mod. vc-50

Rockwell Mardhess Tester

Versitron

Rockinell Mordhess Tester

Mod J. Ser RA26464

Model 8an, Ser 1785

0.00

102

0.00

AB-

\begin{tabular}{rr}
$38-6$ \\
\hline $8-6$ & 18970
\end{tabular}

187-00

6500

5

102

$0.00 \quad A B-6 \quad 18970-00$

4555

$\begin{array}{llll}0.00 & A B-6 & 44707-00,19326-0 & 18063\end{array}$

103

103

0.00

18-6 3810

Rockwell Mardhess Tester

Mod 8503T, SH 82083710

Jarrett Poll isher

Grinder w/ Loed Controller Mod VP-50 w/ AP-50 Cont. Maxinet Grinder

Pol inet (3 each) grinding in Sink Mounted 12ü Pol imet Grinder

Test Machine and Controller Model TTOL / Ser. 1787 Pneumet Mount ing Press Preunet 3

Sink Mounted Press (2)

Pol imet grinders

TY LPOIC, S/N 333582

Vibromet Polisher

103

$0.00 \quad A B-6 \quad 39080-00$

$0.00 \quad A B-6 \quad 38412-00$

$\begin{array}{llll}106 & 0.00 & A B-5 & 19251-00\end{array}$

\begin{tabular}{cccccc}
103 & 0.00 & $A B-6$ & $38412-00$ & 14382 & 5 \\
\hline 106 & 0.00 & $A B-5$ & $19251-00$ & 2722 & 5 \\
\hline 106 & 0.00 & $A B-5$ & $38274-00$ & 114832 & 4 \\
106 & 0.00 & $A B-5$ & $38415-00$ & 975 & 4
\end{tabular}

\begin{tabular}{llllll}
106 & 0.00 & $A B-5$ & $38415-00$ & 975 & 4 \\
\hline 106 & 0.00 & $A B-5$ & $38304-00.38371-0$ & 2925 & 5
\end{tabular}

\begin{tabular}{llllll}
106 & 0.00 & $A B-5$ & $38304-00.38371-0$ & 2925 & 5 \\
\hline 106 & 0.00 & $A B-5$ & $38259-00$ & 2578 & 5 \\
\hline 106 & 0.00 & $A B-5$ & $19243-00$ & 2253 & 5 \\
\hline 106 & 0.00 & AB-5 & & 950 & 5
\end{tabular}

\begin{tabular}{rrrrrr}
106 & 0.00 & $A B-5$ & $19243-00$ & 2253 & 5 \\
\hline 106 & 0.00 & $A B-5$ & & 950 & 5 \\
\hline 106 & 0.00 & $A B-5$ & $33219-00$ & 4549 & 5 \\
\hline
\end{tabular}

\begin{tabular}{llllll}
106 & 0.00 & $A B-5$ & $33219-00$ & 4549 & 5 \\
\hline 106 & 0.00 & $A B-5$ & $38301-00$ & 0 & 5 \\
\hline 106 & 0.00 & $A B-5$ & $38279-00$ & 7218 & 5 \\
\hline 106 & 0.00 & $A B-5$ & $36719-00$ & 2150 & 5
\end{tabular}


Rocky Flats Equipment Dato

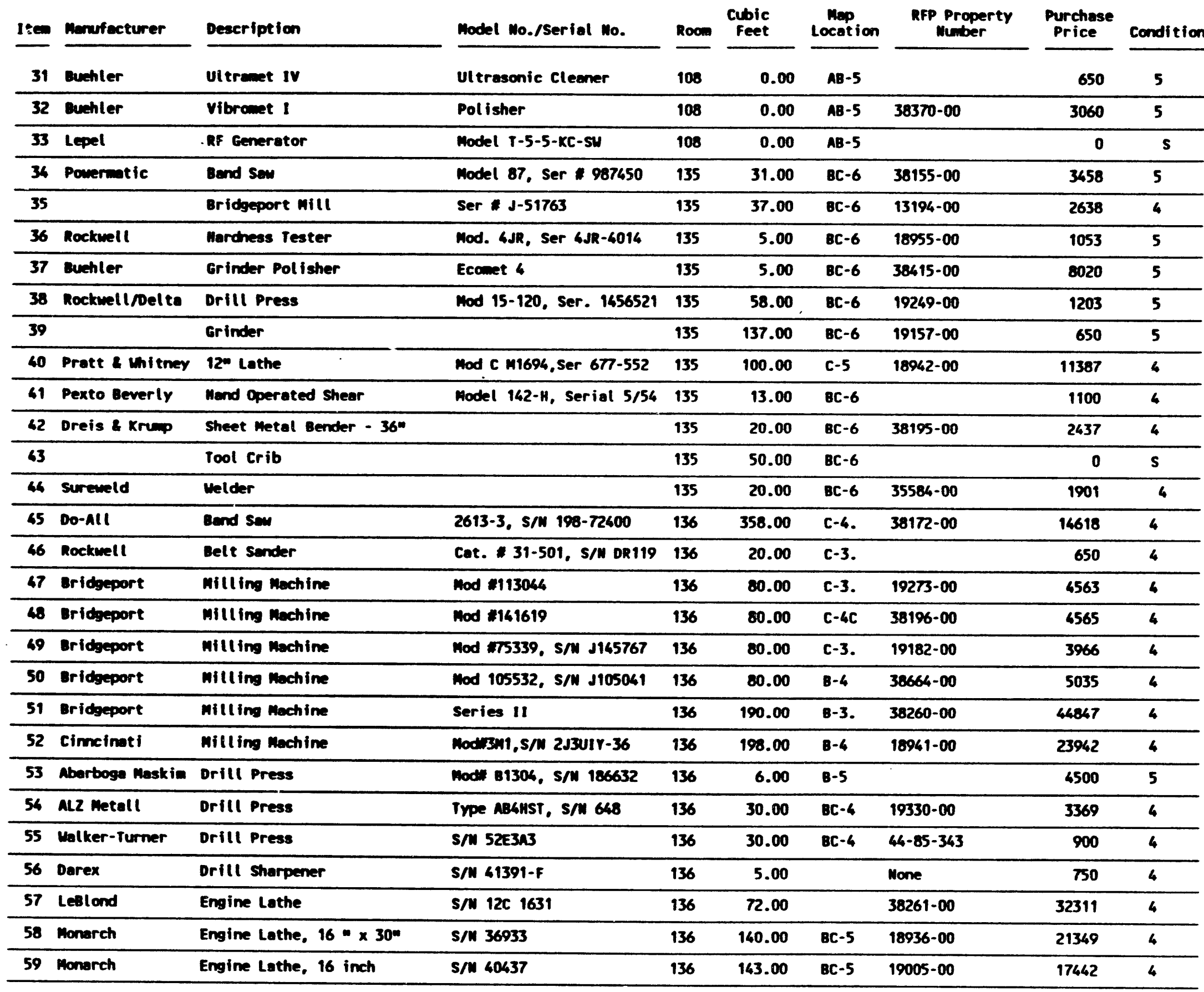




\begin{tabular}{|c|c|c|c|c|c|c|c|c|c|}
\hline Item & Monuf ecturer & Deseription & Model Mo./Serial Mo. & Room & $\begin{array}{c}\text { Cubic } \\
\text { Feet }\end{array}$ & $\begin{array}{c}\text { Map } \\
\text { Location }\end{array}$ & $\begin{array}{l}\text { RFP Property } \\
\text { Muiber }\end{array}$ & $\begin{array}{l}\text { Purchese } \\
\text { Price }\end{array}$ & Condition \\
\hline 60 & Monarch & Engine Lethe, 20 inch & $S / 1135447$ & 136 & 192.00 & $8 C-5$ & $18994-00$ & 21723 & 4 \\
\hline 61 & Monerch & Engine Lathe, 60 inch & $5 / 114984$ & 136 & 143.00 & $8 C-5$ & $38544-00$ & 19673 & 4 \\
\hline 62 & Recine & Hack Sem, 14 inch & oil cut & 136 & 26.00 & $B C-4$ & $13164-00$ & 1896 & 5 \\
\hline 63 & Black $\&$ Decker & Pedestol Grinder & 45934644 & 136 & 10.00 & & & 650 & 5 \\
\hline 64 & Hewnond & Pedestal Grinder & mo 12-A, S/M 6914 & 136 & 25.00 & & $38182-00$ & 1562 & 5 \\
\hline 65 & Ealdor & Pedestal Grinder-Buffer & S/N F983 & 136 & 10.00 & & & 950 & 5 \\
\hline 66 & Brown 2 starpe & Surface Grinder $\$ 618$ Micro & $S / 1 / 523-6181-1742$ & 136 & 137.00 & $c-3$ & 19157-00 & 11787 & 5 \\
\hline 67 & Cutter Master & Tool Grinder & MDT-30, S/M 016 & 136 & 8.00 & & $38429-00$ & 2612 & 5 \\
\hline 68 & Mardinge & Tool Room Lathe & $m L V-H$ & 136 & 52.00 & $8 c-3$ & $19261-00$ & 10073 & 4 \\
\hline 69 & Mardinge & Tool Room Lathe & $m L v-n$ & 136 & 52.00 & $B C-3$ & $38153-00$ & 13993 & 4 \\
\hline 70 & Merdinge & Tool Room Lathe & $m e v-n$ & 136 & 52.00 & $B C-4$ & $38368-00$ & 36337 & 4 \\
\hline 71 & Mardinge & Tool Room Lathe & HLV-H & 136 & 52.00 & $8 C-4$ & $63904-00$ & 20272 & 4 \\
\hline 72 & Bullard & Vertical Turret Lathe & $64^{\prime \prime}$ Cutmester, A.F. \$261 & 145 & 2160.00 & E-5 & $38189-00$ & 67032 & 0 \\
\hline 73 & & Air Compressor & & 140 & 0.00 & & & 0 & 5 \\
\hline 74 & & Power switches & & 140 & 0.00 & & & 0 & $\mathbf{s}$ \\
\hline 75 & & Punps & & 140 & 0.00 & & & 0 & s \\
\hline 76 & & steen supply & & 140 & 0.00 & & & 0 & s \\
\hline$\pi$ & & Water Meader & & 140 & 0.00 & & & o & $\mathbf{s}$ \\
\hline$\pi$ & & Water Recirculator & & 140 & 0.00 & & & 0 & $\mathbf{s}$ \\
\hline 79 & & RPT Office & & 163 & 0.00 & & & $\mathbf{0}$ & s \\
\hline 80 & Buchler & Abresive Cutoff Sew (Small) & $12^{\circ}$ & 146 & 50.00 & $F-2$ & $19299-00$ & 1143 & s \\
\hline 81 & mone & Be Preparation Cau Box & Mone & 146 & 144.00 & E-1. & $w / A$ & 0 & \\
\hline 82 & Detrex & Degreeser & useoos & 144 & 325.00 & EF-1 & $19197-00$ & 4347 & s \\
\hline 83 & Mil workee & Grinder & S/H LR 14683 & 144 & 10.00 & & & $\mathbf{0}$ & $\mathbf{s}$ \\
\hline 84 & & Sinks (2 each) & & 144 & 0.00 & & & 0 & s \\
\hline 85 & Lincberg & Tube furnace 2 Evac. Ass'y. & 56752-S, S/W 819172 & 164 & 100.00 & $E-2$ & $38230-00,31-00$ & 4768 & $\mathbf{s}$ \\
\hline 86 & Continental & Abrasive Cut-off Sew, 34 inc & Ulticut Mod" 344575-3 & 145 & 819.00 & F-3. & 38158-00 & 32014 & 5 \\
\hline 87 & Nobert & Battery Charger (3 each) & $3 T 18-960$ & 145 & 0.00 & & & 0 & $\mathbf{s}$ \\
\hline 80 & Mone & Be Glovebox, inert & none & 145 & 864.00 & $E-2$ & N/A & $\mathbf{0}$ & $\mathbf{s}$ \\
\hline
\end{tabular}




\begin{tabular}{|c|c|c|c|c|c|c|c|c|c|}
\hline Iten & Manufecturer & Deseription & Model Mo./Serial Mo. & Room & $\begin{array}{c}\text { Cubic } \\
\text { Feet }\end{array}$ & $\begin{array}{l}\text { Mep } \\
\text { Location }\end{array}$ & $\begin{array}{l}\text { RFP Property } \\
\text { Number }\end{array}$ & $\begin{array}{l}\text { Purchase } \\
\text { Price }\end{array}$ & Condition \\
\hline 89 & Diversified Met & De Preparation Dox & None & 145 & 348.00 & & $38404-00$ & 10358 & $\mathbf{s}$ \\
\hline 90 & Milwakee & Bench Grinder & S/M LR 15562 & 145 & 10.00 & & & $\mathbf{0}$ & s \\
\hline 91 & Thernolme & Sox Furnace & $3 F-1856 \mathrm{~S} / \mathrm{M} 16430$ & 145 & 72.00 & D-4 & $0-083-0451-00000$ & o & $\mathbf{s}$ \\
\hline 92 & Thernolye & Box Furnece & $3 F-1886 \mathrm{~S} / \mathrm{M} 16646$ & 145 & 72.00 & DE-3 & $D-444-4223-37367$ & o & $\mathbf{s}$ \\
\hline 93 & Lindberg & Box Furnace, Solo Basic $6^{n} x$ & $\operatorname{Mod} 59545$, Ser 777319 & 145 & 18.00 & DE-3 & & 6500 & 5 \\
\hline 96 & Pexto & Circle shear & 535-D S/N 673032 & 145 & 32.00 & $E-3$ & $.45088-00$ & 2400 & 4 \\
\hline 95 & Barrett Powerox & Die stacker & MPG-40-DP S/I 12-70112 & 145 & 157.00 & & 38148-00 & 7001 & 4 \\
\hline 96 & Fern & Drew Bench & & 145 & 706.00 & $F-2$ & $38202-00$ & 43490 & 4 \\
\hline 97 & Lelend Gifford & Orill Press & Mod/Ser $14 a 959$ & 145 & 128.00 & GH-5 & $23154-00$ & 1078 & 5 \\
\hline 98 & Rockmell mil. & Drill Press & DP225 S/N1 123-6866 & 145 & 16.00 & & & 900 & 5 \\
\hline 9 & Lexbold-Herseus & Electron Beem furnace & $E B \quad 447$ & 145 & 3625.00 & $c-4$ & $20741-00$ & 185056 & o \\
\hline 100 & Sutton & 2000 Ton Extrusion Press & $5 / N 1825$ & 145 & 15670.00 & $F-4$ & $38267-00$ & 3895340 & 4 \\
\hline 101 & Automatic & Fork Truck & EF-80 S/M C71502 & 165 & 184.00 & & $38142-00$ & 15174 & 4 \\
\hline 102 & Lewis-Shepard & 2000 lb Cep Fork Truck & HFFTT-2 S/M N-398 & 145 & 90.00 & & 20733-00 & 5941 & 4 \\
\hline 103 & All is Cholmers & $4000 \mathrm{lb}$ Cep fork Truck & ACE $40 \mathrm{CR}$ S/M DB80162 & 145 & 143.00 & & $38190-00$ & 14372 & 4 \\
\hline 104 & Lindbers & Furnace & Trpe 11-5C-364836-29AS, & 145 & 1395.00 & DE-4 & $38213-00$ & 180746 & 5 \\
\hline 105 & Lindberg & Furnace & Type 11-3C-364836-29As, & 145 & 1395.00 & G-4 & $38212-00$ & 201069 & 5 \\
\hline 106 & Despatch & 1450 F Furnace, $20 \mathrm{~km}$ & $5 / 1181542$ & 145 & 231.00 & $E-3$ & $38161-00$ & 20221 & $\mathbf{s}$ \\
\hline 107 & Frees & Furnoce & 845-A & 145 & 40.00 & & 19323-00 & 1725 & s \\
\hline 108 & Marper Pit furn & 1500 C Electric Furnace & M4S-36060-P-28-8P S/M V- & 145 & 565.00 & $E-4$ & $38177-00$ & 125455 & s \\
\hline 109 & Vecum Indestri & Furnace & & 145 & 663.00 & $\mathbf{C D}-2$ & 43792-00, 38201- & 116124 & 5 \\
\hline 110 & Lindberg & $1370 \mathrm{C}, 95 \mathrm{KW}$, Furnece & Trpe 11-sc-364824-25AS & 145 & 1080.00 & DE-2 & $38178-00$ & 37034 & 5 \\
\hline 111 & Norton & Furnace, Mi-temp. & Roll around & 165 & 315.00 & $0-2$ & $43803-00$ & 19948 & 5 \\
\hline 112 & A Bar & 1200 C,Furnace, Migh Vacum & $m-50 L \mathrm{~s} / \mathrm{M} \mathrm{mR}-50 \mathrm{~L}-302$ & 165 & 1752.00 & $0-3$ & $38192-00,93,94,1$ & 16112 & 5 \\
\hline 113 & A Bar & 1600 C, Vecum Furnece & Model 90 & 145 & 223.00 & D-3. & $19284-00$ & 18122 & 5 \\
\hline 114 & Lindberg & Glass Tube Furnace & $10,59546,5 / 11114813$ & 145 & 30.00 & $F-2$ & $F-2$ & o & $\dot{\mathbf{s}}$ \\
\hline 115 & Satec Systems, & Gradient Bar Furnace & Model GF, S/I 1009 & 145 & 45.00 & $F-2$ & $38206-00$ & 9975 & $\mathbf{s}$ \\
\hline 116 & Liquid Honing & Grit Balster, liquid & 4836, $5 / 115993$ & 145 & 112.00 & $\mathrm{H}-5$ & $38226-00$ & 3907 & 4 \\
\hline 117 & Peerless & Hack San & Lim 450 s/M PSO1S & 145 & 90.00 & $6-3$ & $38400-00$ & 9485 & 5 \\
\hline
\end{tabular}




\begin{tabular}{|c|c|c|c|c|c|c|c|c|c|}
\hline item & Menufacturer & Description & Model Mo./Serial Mo. & Room & $\begin{array}{c}\text { Cubic } \\
\text { Feet }\end{array}$ & $\operatorname{Map}_{\text {Location }}$ & $\begin{array}{l}\text { RFP Property } \\
\text { Mumber }\end{array}$ & $\begin{array}{l}\text { Purchase } \\
\text { Price }\end{array}$ & Condition \\
\hline 118 & Recine & Pouver Mock Sow & 6614 & 145 & 270.00 & $c-5$ & $19186-00$ & 5233 & 5 \\
\hline 119 & Racine & Mack Sen & 66114 & 145 & 270.00 & G-3. & & 1969 & 5 \\
\hline 120 & Autocleve & Not Isestatic Press & & 145 & 960.00 & DE-5 & $38360-00$ & 526175 & 4 \\
\hline 121 & Cincinatti & Mydrospin & & 145 & 6695.00 & DE-1 & $38161-00$ & 68000 & 4 \\
\hline 122 & Lepel & Induction Coil & T-2.5-1-KC-8U S/M 7158-A & 145 & 22.00 & $c-2$ & $44739-00$ & 2702 & 5 \\
\hline 123 & Meroeus-Engleha & Induction furnace & Luso/111 & 145 & 100.00 & & & 1972 & s \\
\hline 126 & Cont inental & 34" Abrasive Cutoff Saw & & & 819.00 & & & 0 & $\mathbf{s}$ \\
\hline 125 & CEC & Leak Detector & Mod: $24-120 A$ & 145 & 16.00 & $\mathrm{CD}-2$ & $13226-00$ & 4317 & 4 \\
\hline 126 & Varien & Leak Detector & $938-41$ & 145 & 7.00 & & $40332-00$ & 13570 & 4 \\
\hline 127 & Lift-A-Loft & 500 Lb Cepecity Lifter & Mod. 25.0-3-1, S/M LA42 & 145 & 370.00 & FG-3 & $38169-00$ & 18823 & 4 \\
\hline 128 & GE of Canada & Manmate & $47151881, \mathrm{KT}-3275$ & 145 & 683.00 & $F-4$ & $38203-00$ & 127614 & 4 \\
\hline 129 & & Material Storage & & 145 & 0.00 & & & o & \\
\hline 130 & Blue M Elec. Co & Oil Bath Heater & Magni-Whirl & 145 & 27.00 & $6-5$ & $D \cdot 83-859-94756$ & 0 & $\mathbf{s}$ \\
\hline 131 & Lindberg & Portable Box Furnace & S9845-E1-B-D1, S/M 84916 & 145 & 97.00 & GH-5 & $38334-00$ & 6199 & $\mathbf{s}$ \\
\hline 132 & Tinius olson & Press, 60,000 lbs. & $?$ & 145 & 216.00 & $F-5$ & $18969-00$ & 14571 & 5 \\
\hline 133 & Wone & Dench Tenk & Mone & 145 & 106.00 & & None & $\mathbf{0}$ & s \\
\hline 134 & Peck, Stow, \& U & Roller, Former- 20 Ge. Cap. & 383-D, S/M 12/73 & 145 & 6.00 & E-3 & & 970 & 5 \\
\hline 135 & stemnet & Rolling Mill & Modit ra315-5x8 & 145 & 168.00 & E-3. & $63804-00$ & 37460 & 4 \\
\hline 136 & Fem & 7w. 18.4 M.P. Rolling Mill & $5 / 1 N$ H-8219 & 145 & 168.00 & $E-3$ & M/A & 2500 & 4 \\
\hline 137 & United & Rolling Mill & 24 inch & 145 & 1700.00 & DE-6 & 38145-00 through & 160597 & 4 \\
\hline 138 & Molden & Salt Bath & 362 & 165 & 336.00 & EF-3 & $38191-00$ & 5563 & $\mathbf{s}$ \\
\hline 139 & Lindberg & Salt Bath & 59346-B-E1 S/M 800707 & 145 & 56.00 & EF-4 & $02100-00$ & 3725 & $\mathbf{s}$ \\
\hline 140 & Diecro & Sheer, 4 & $s / 112001$ & 145 & 4.00 & & & 2500 & 5 \\
\hline 161 & Lodse \& shipley & Shear, $5 / 8$ inch square $\times 61$ & 1006, S/M 48180, series & 145 & 648.00 & E-3. & $38159-00$ & 44881 & 4 \\
\hline 142 & Miller & Spot Uelder, Resistence & MPS-20 S/W JE768552 & 145 & 8.00 & & & 1200 & 5 \\
\hline 163 & Vidror & Stacker-Retriever & 1000 lbs & 145 & 20.00 & $E-5$ & $38184-00$ & 16515 & 4 \\
\hline 164 & Erie & Steen Forging Mawner & 5000 lbs. & 145 & 5432.00 & G-6 & $38160-00$ & 152060 & 5 \\
\hline 145 & Fem & Swoger & Modil SF & 145 & 144.00 & FG-3 & $19038-00$ & 14239 & 5 \\
\hline 166 & Fern & Swager, Large & Modil of, S/N 105 & 145 & 864.00 & G-3 & $38180-00$ & 20000 & 5 \\
\hline
\end{tabular}




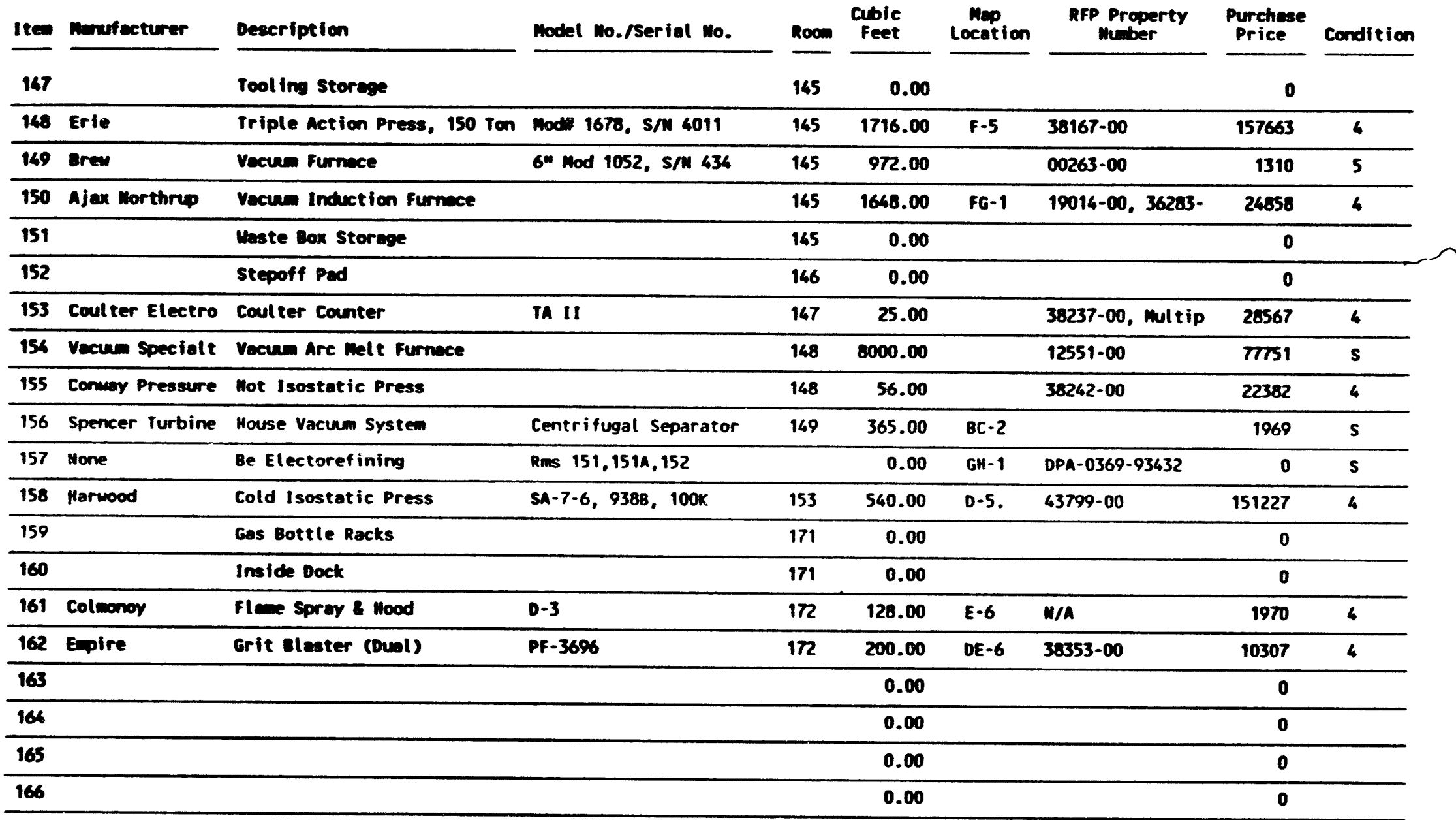




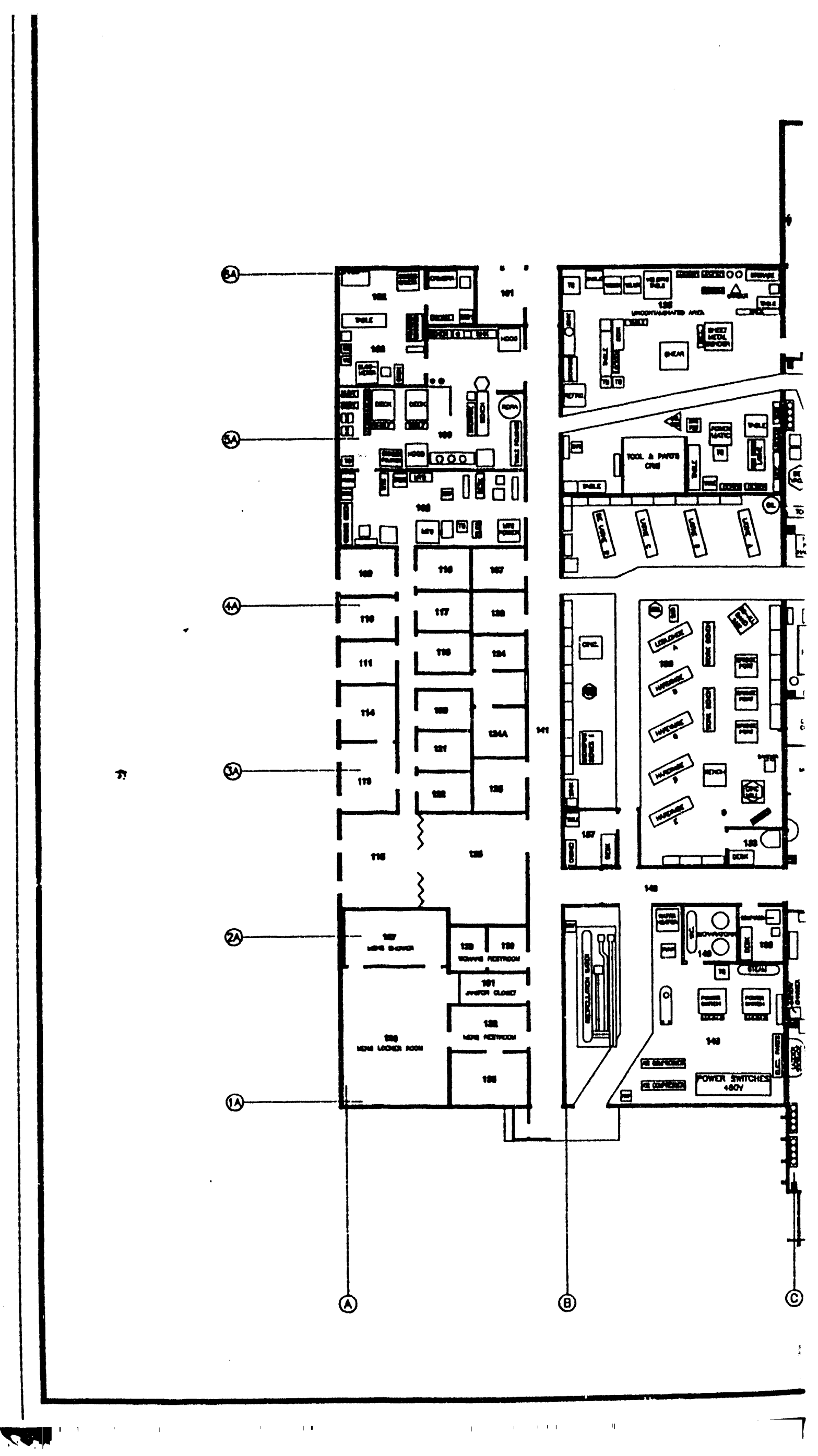




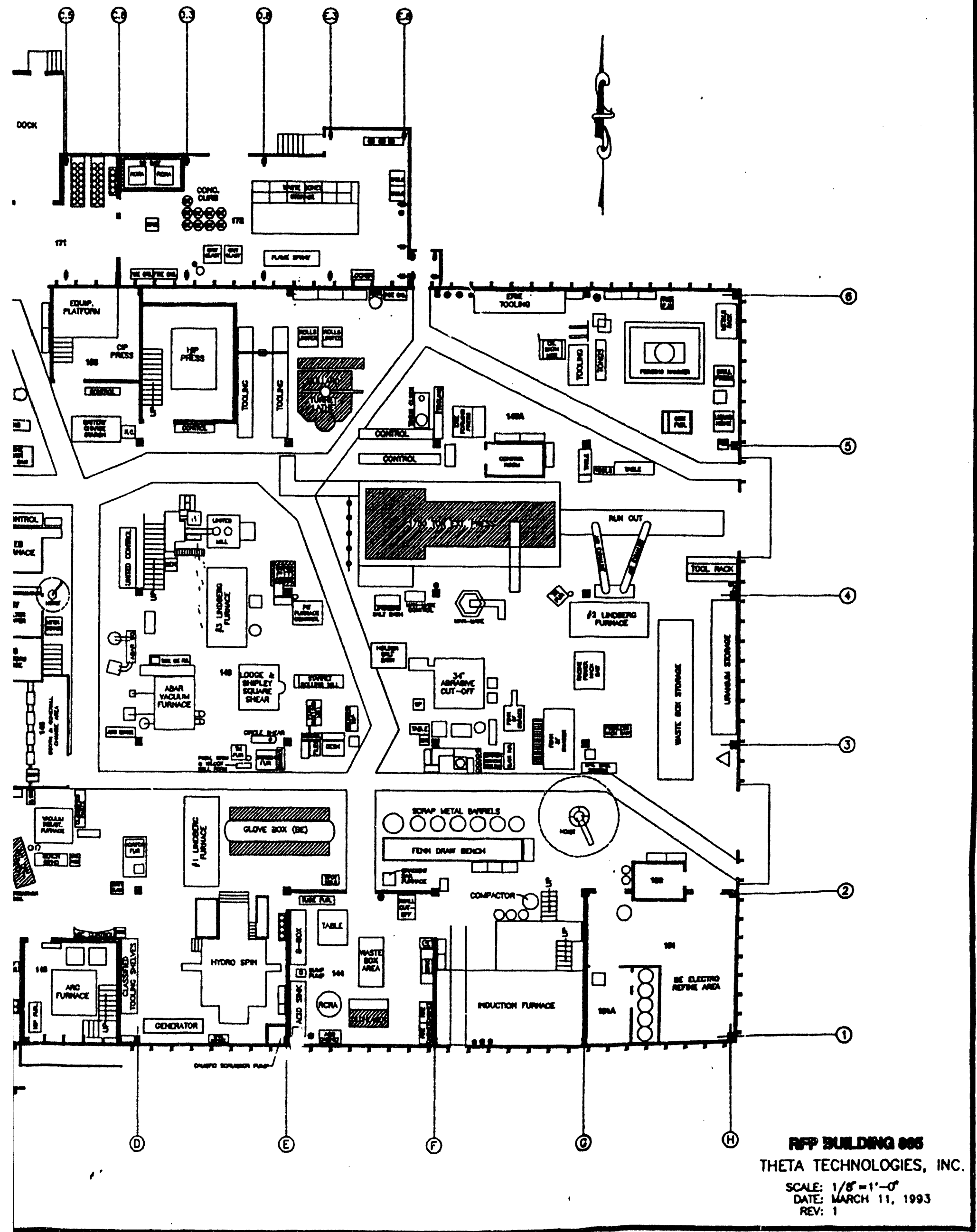

|

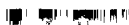




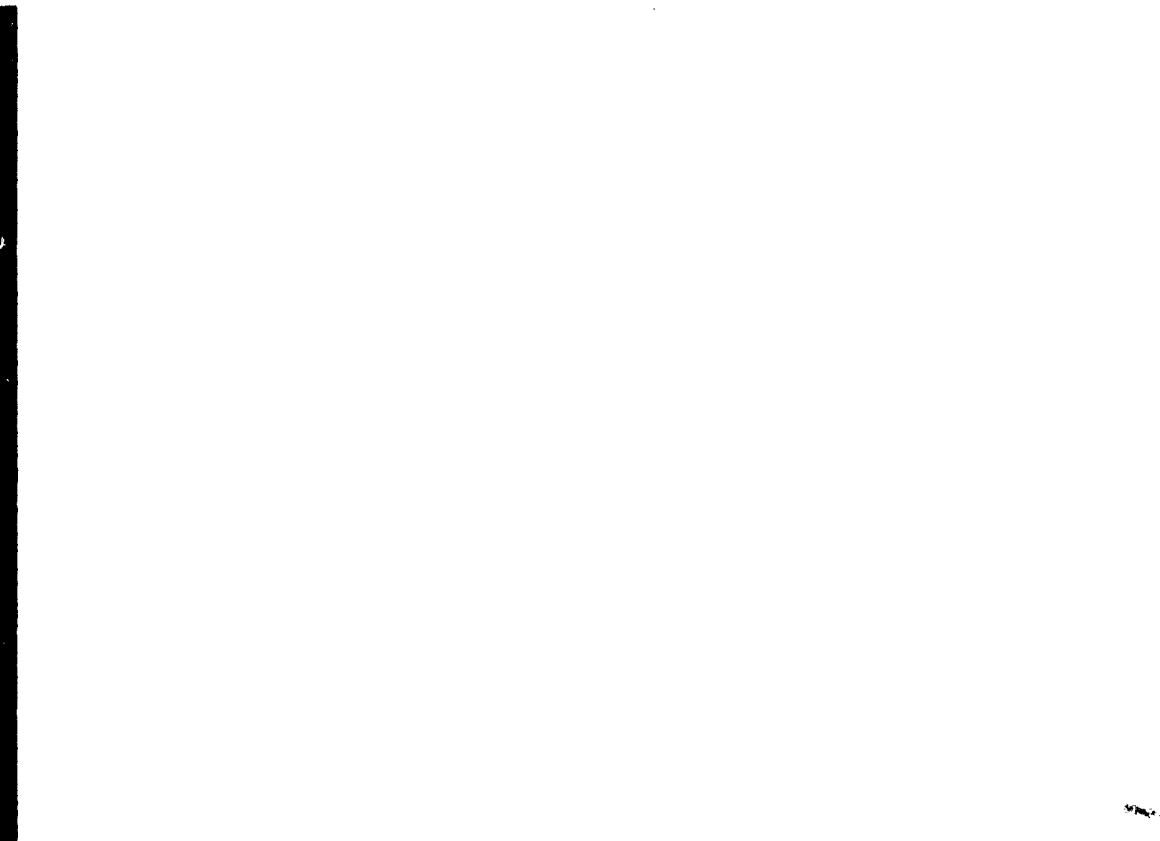

(6A)<smiles>CCCCCC</smiles> 


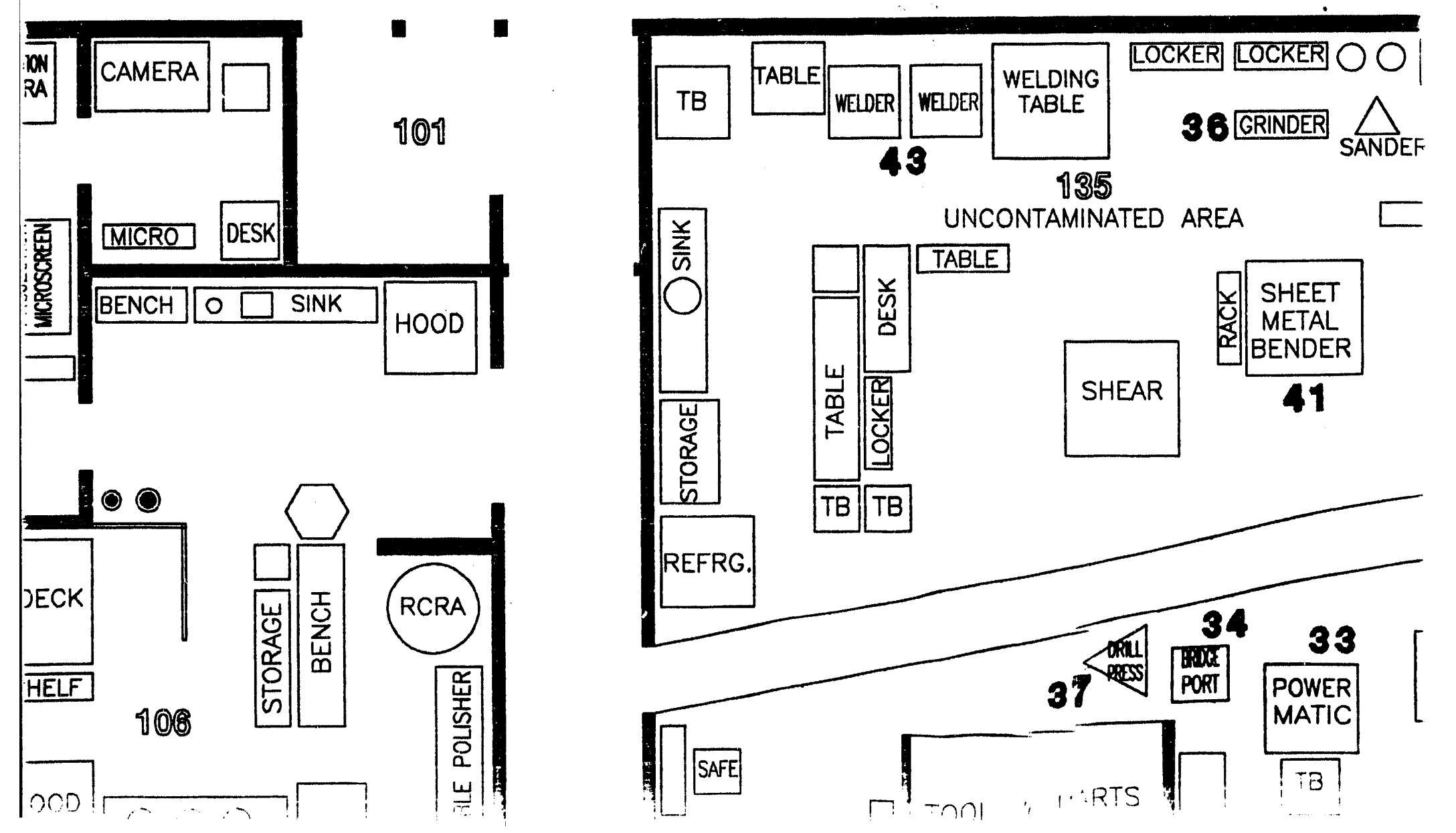




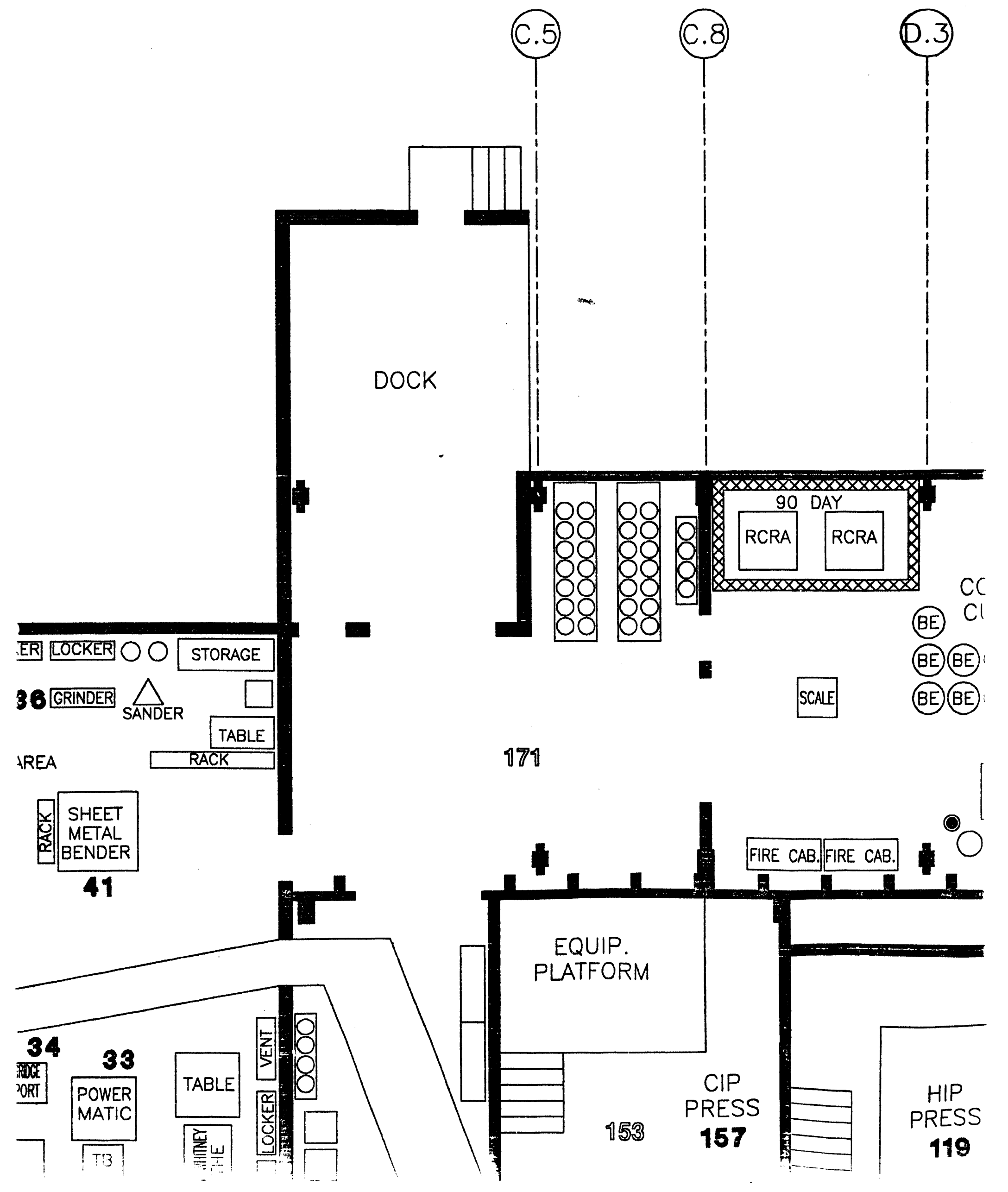


3)

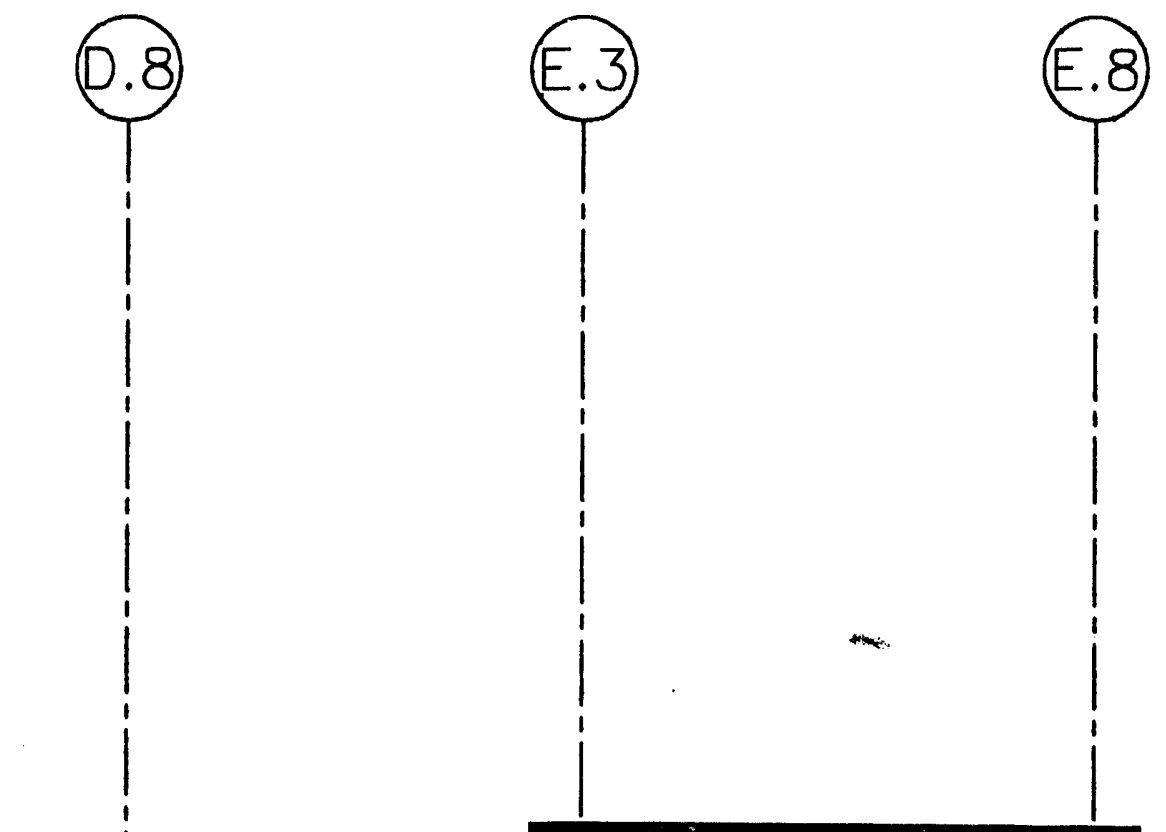

CONC.

) CURB

(BE) (BE) (BE)

(BE BE BE 172

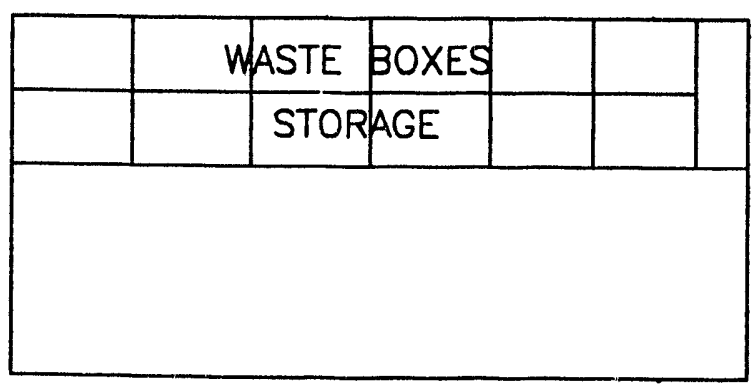

TABLE
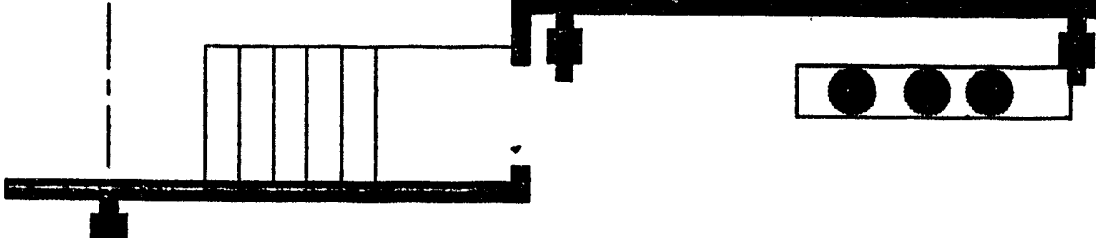

4 

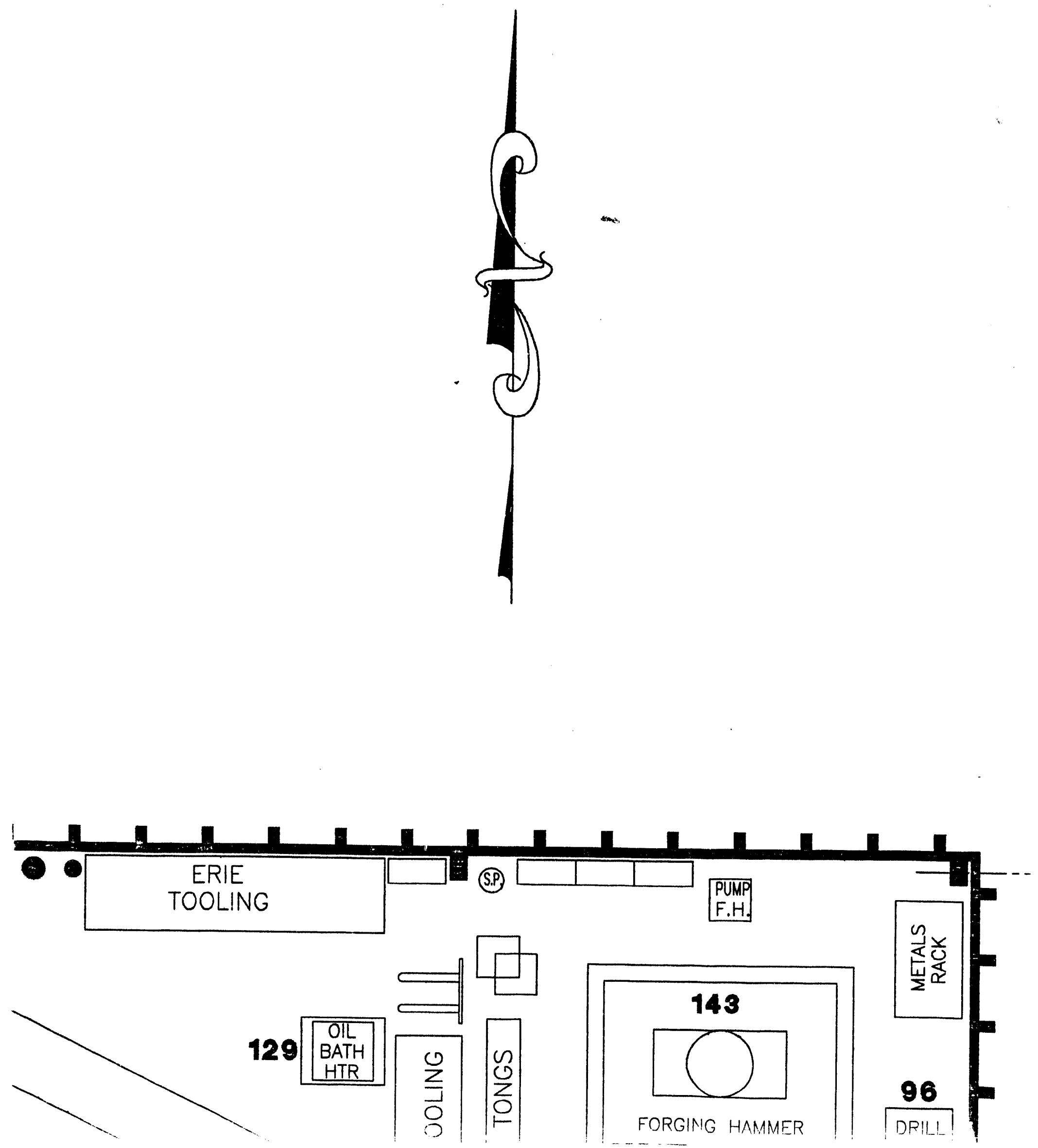



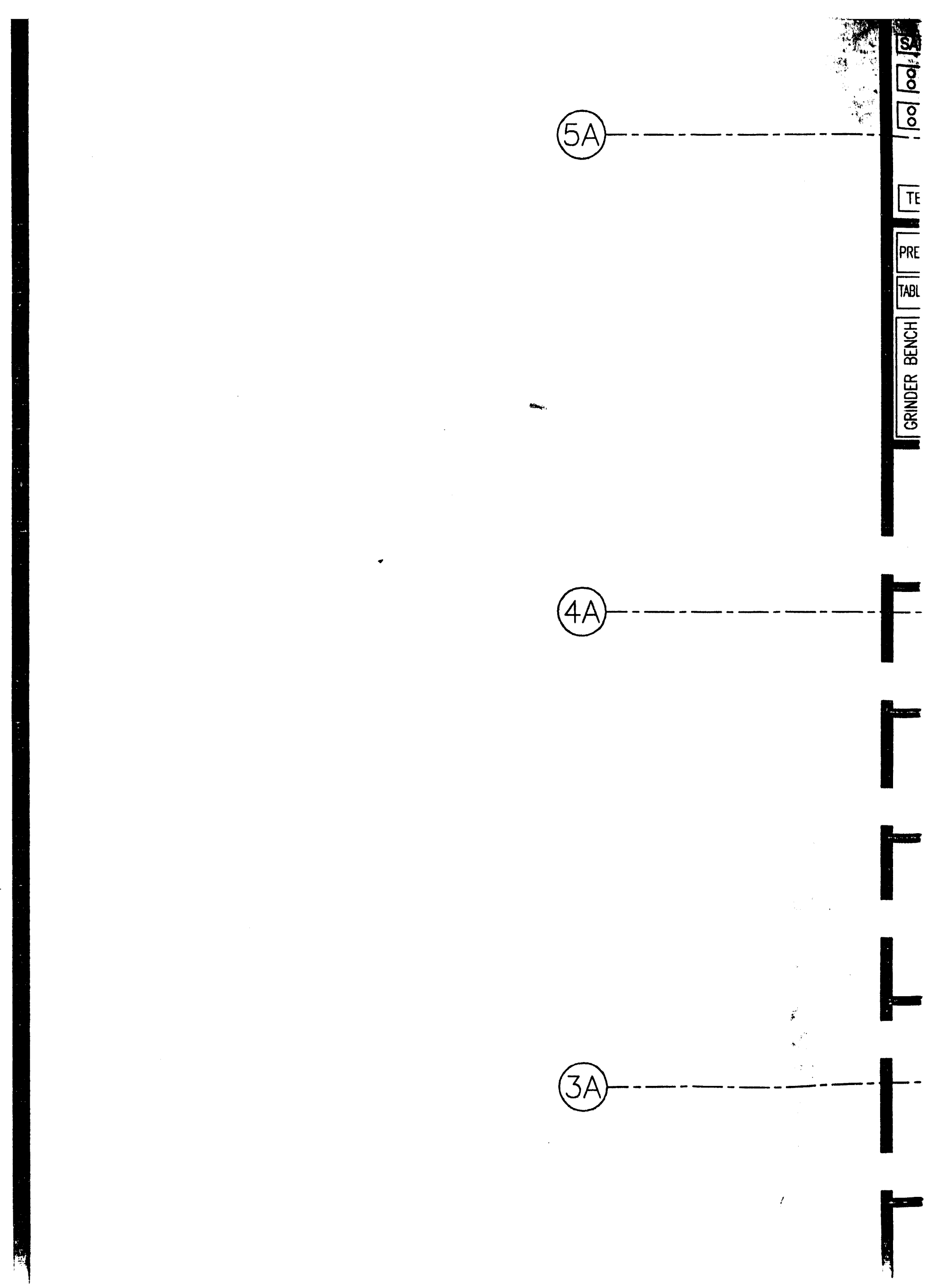




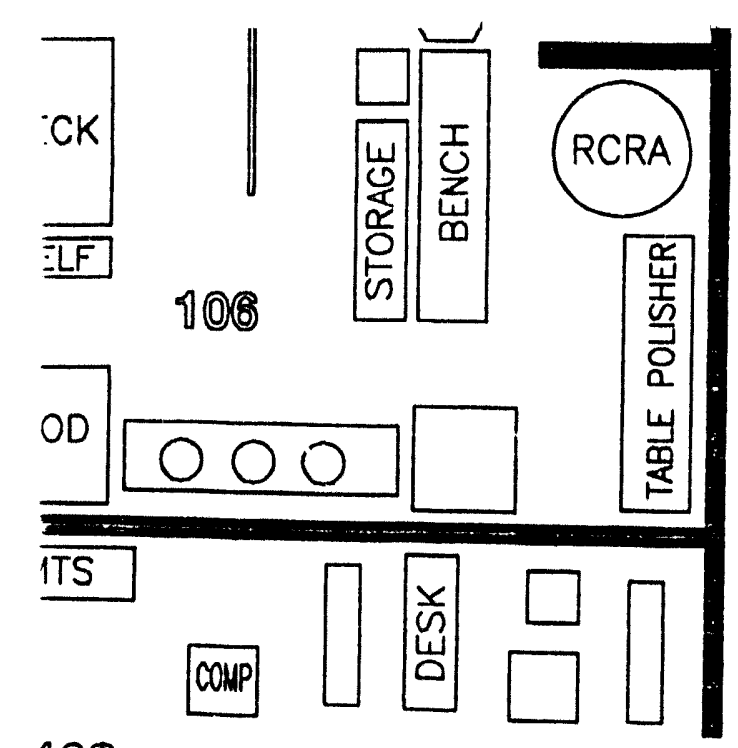

108

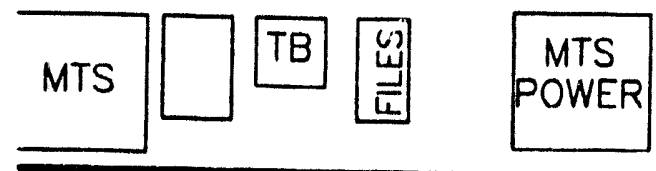

118

107

117

123

118

124

120

12ง

124A

125
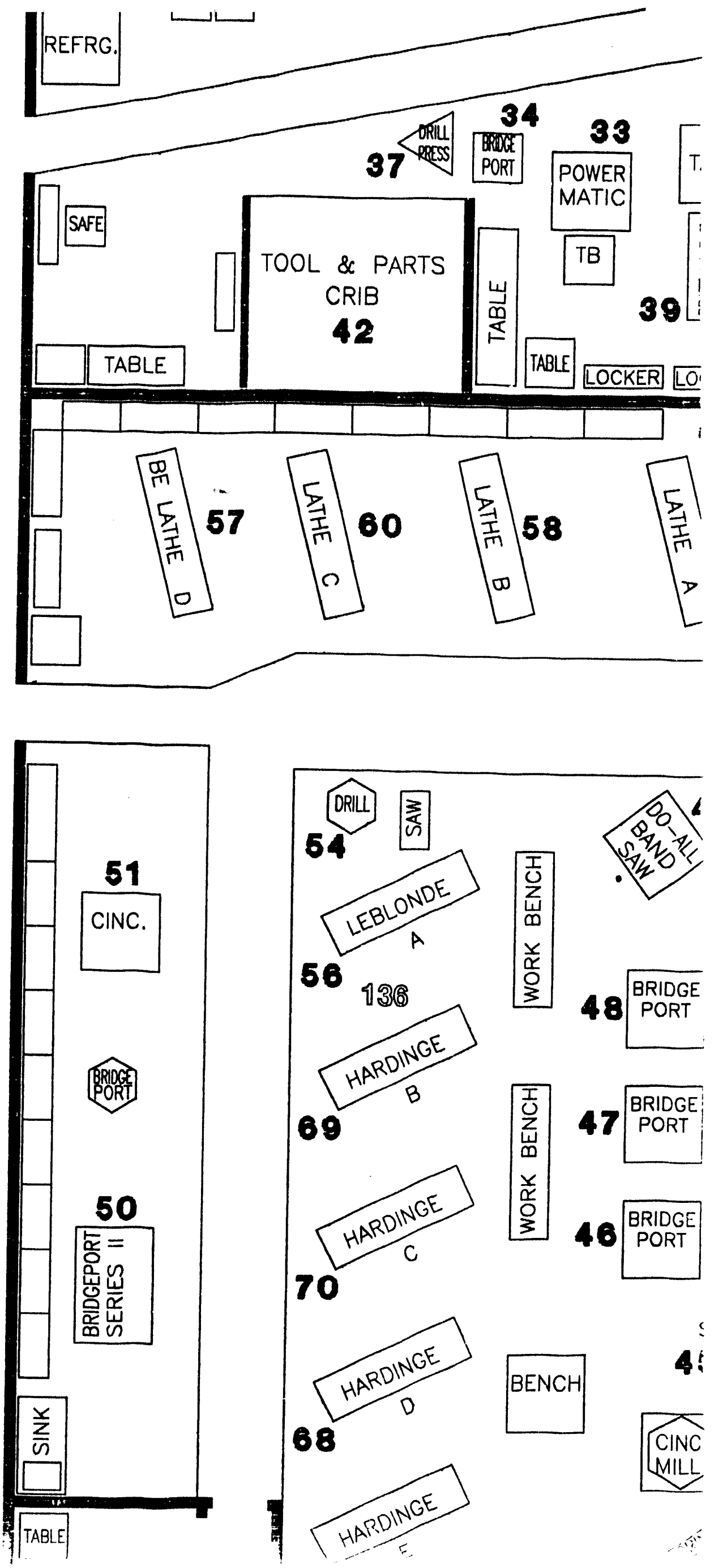

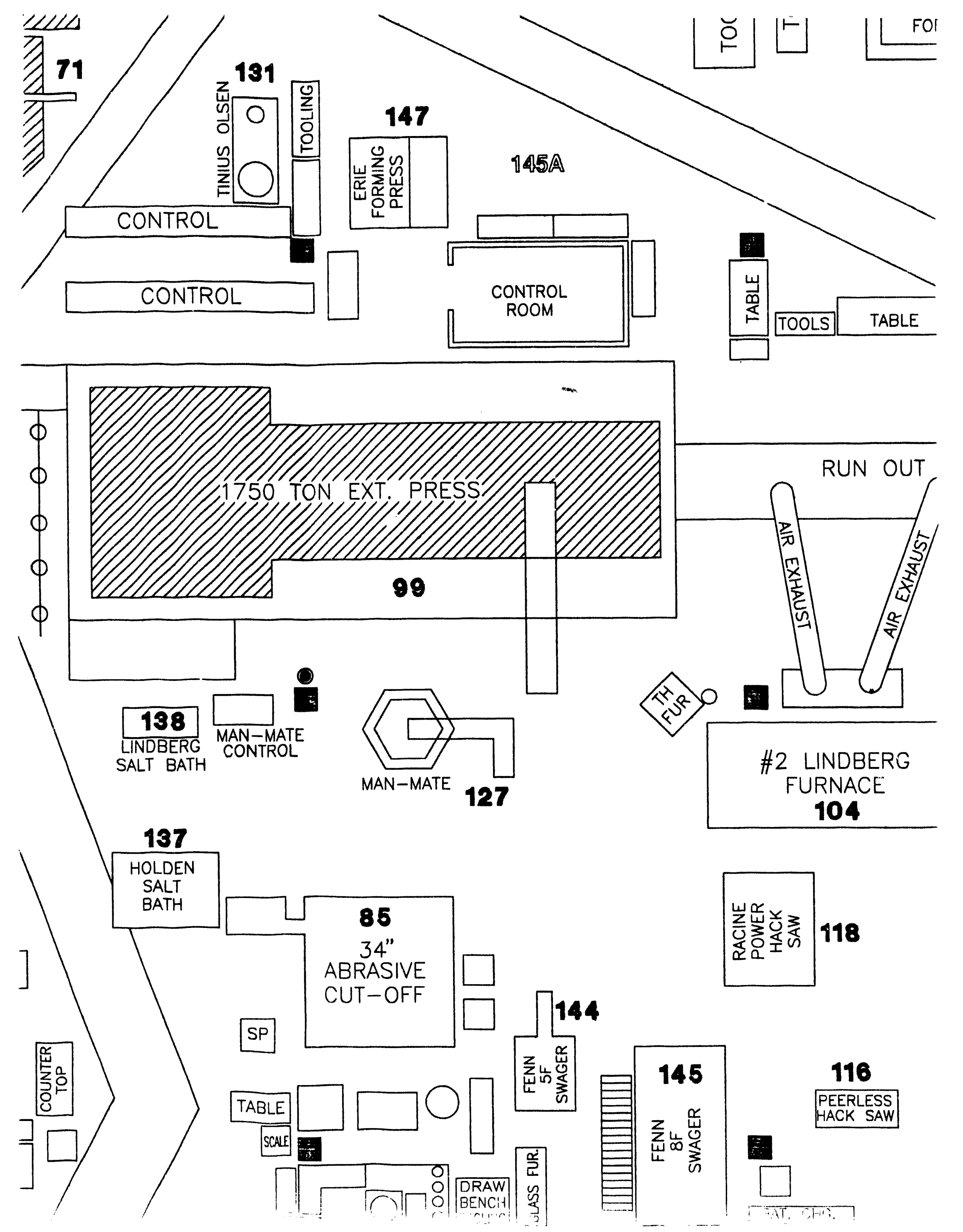


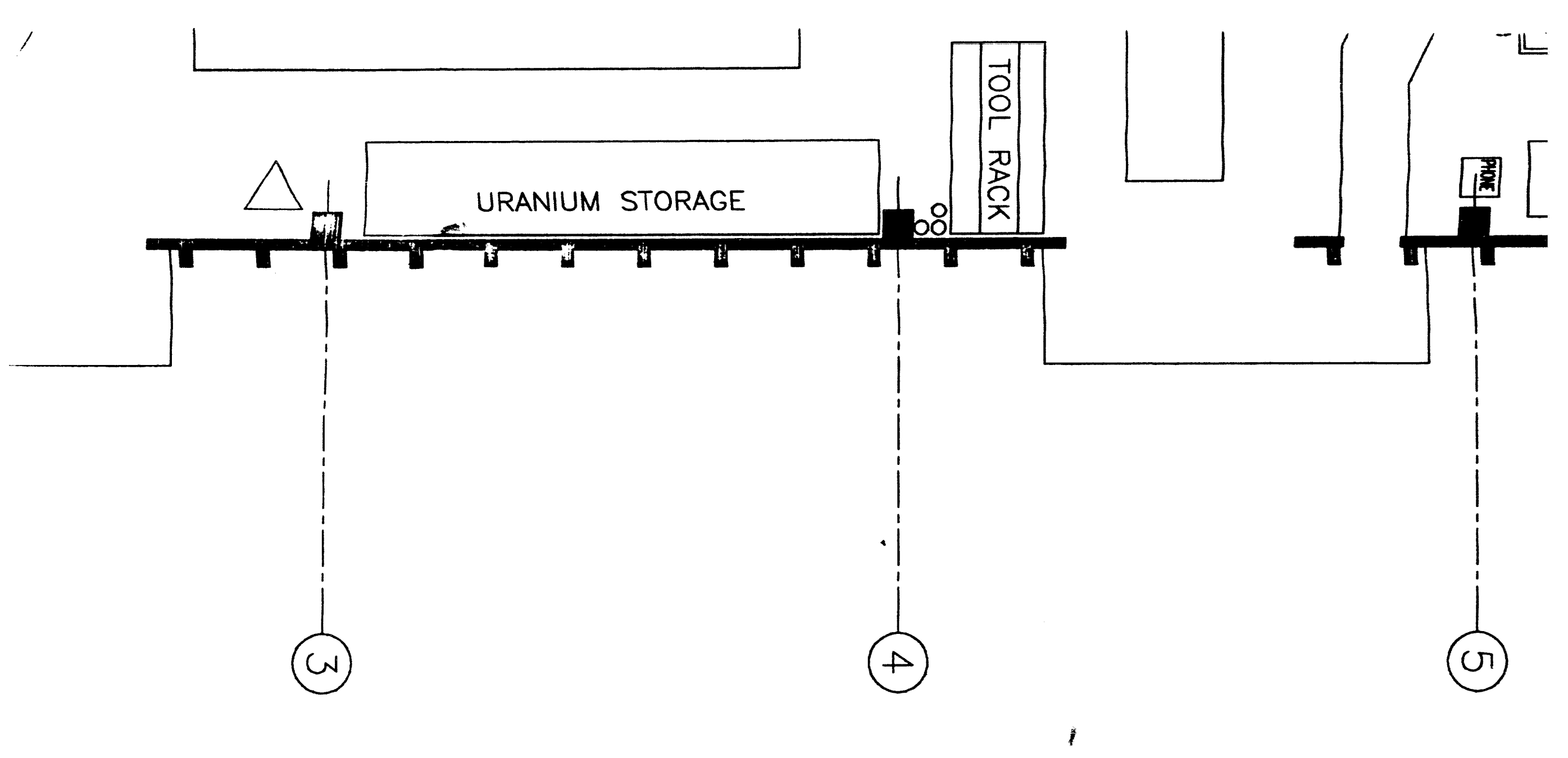




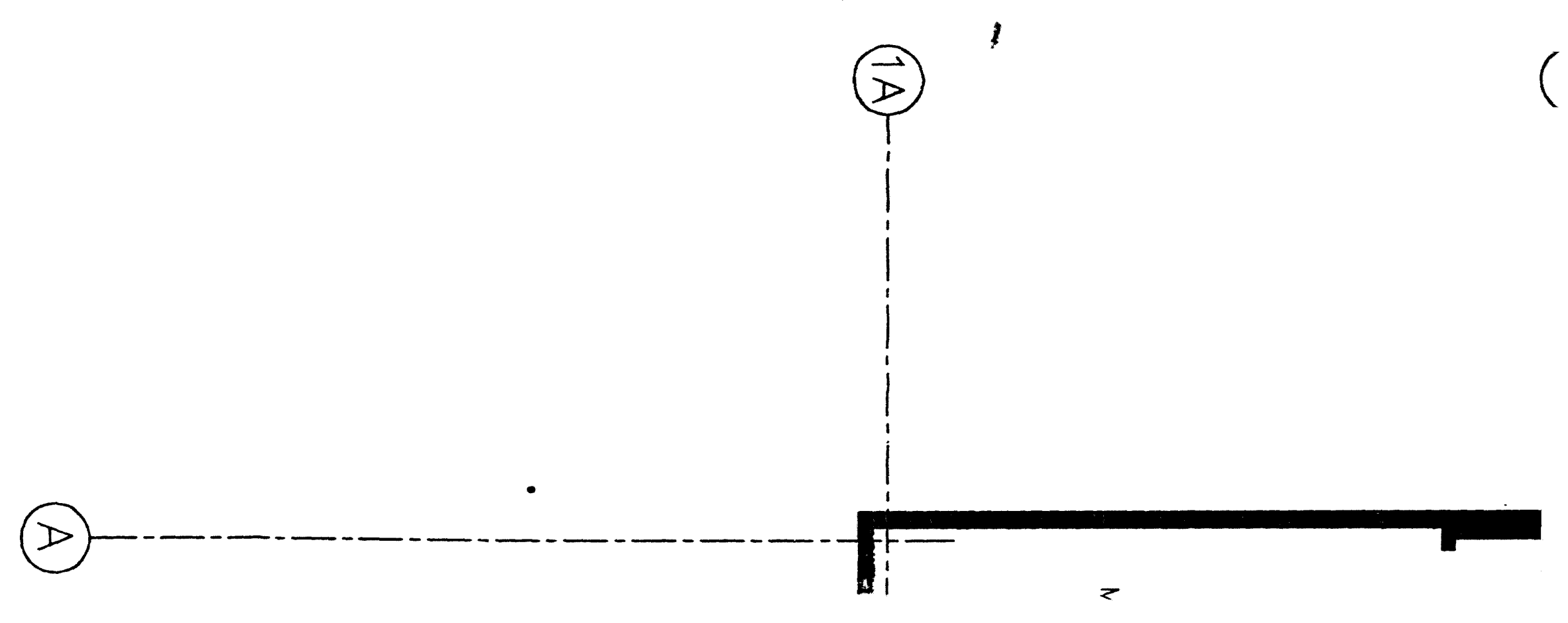




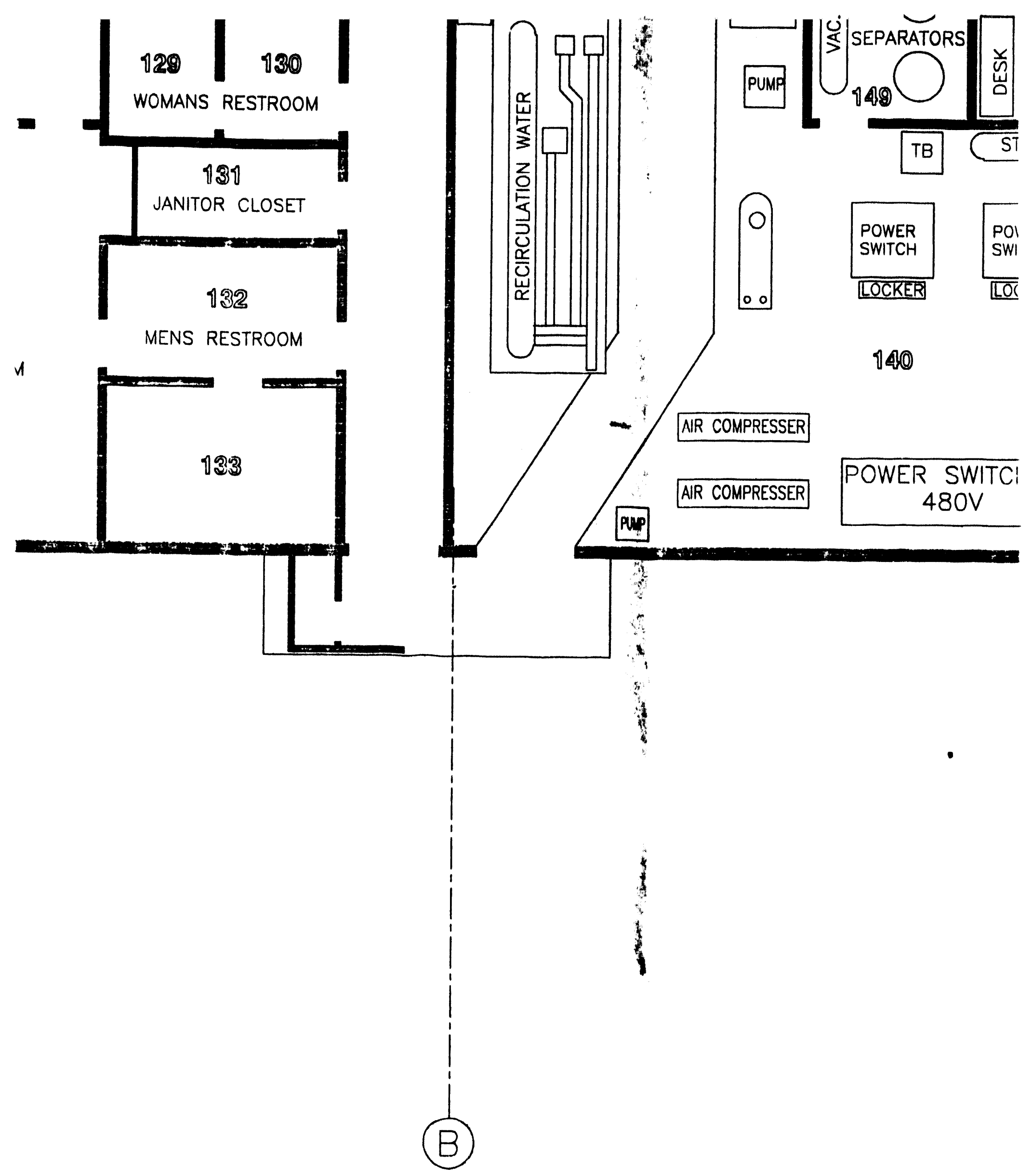



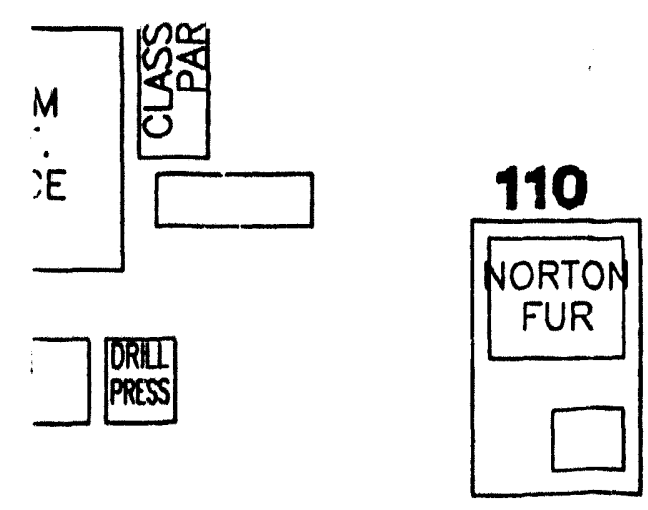

GRIT BLAST
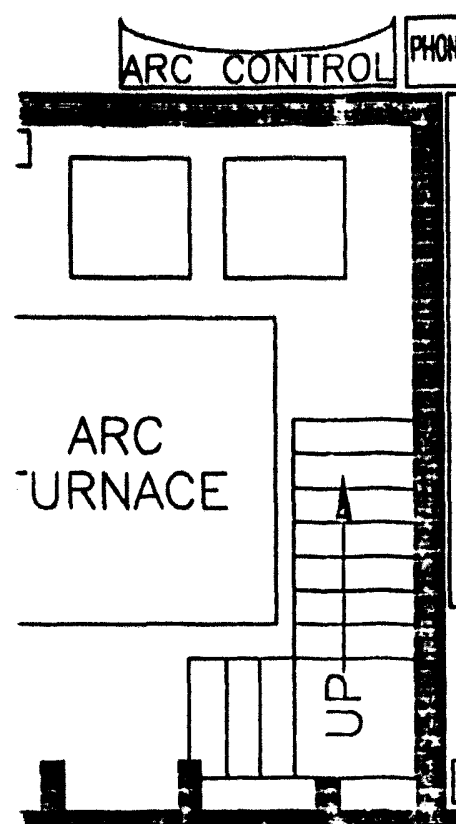

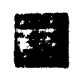
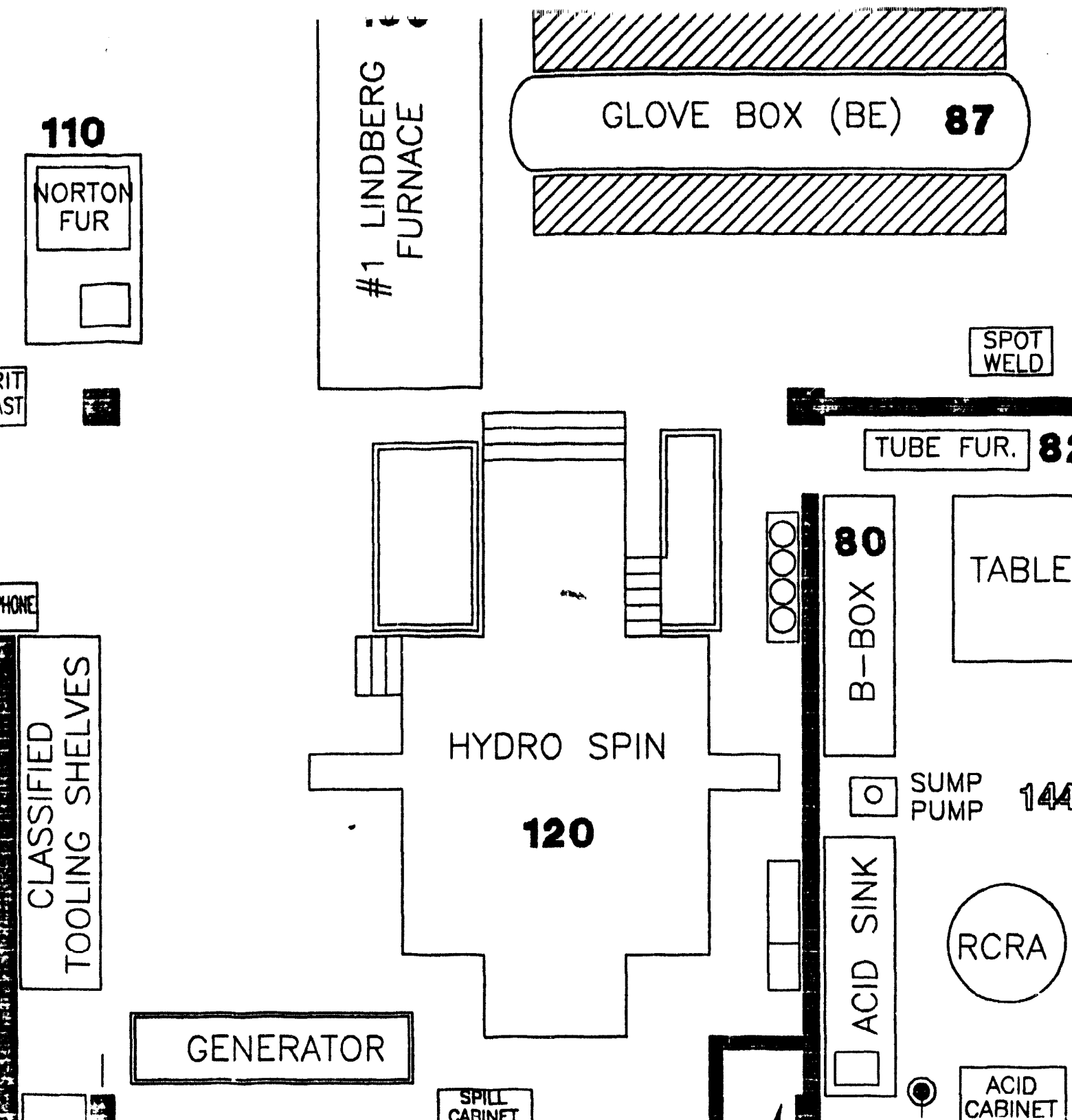

\section{GENERATOR}

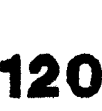

SUMP 144

TABLE

음

1

TUBE FUR. 82
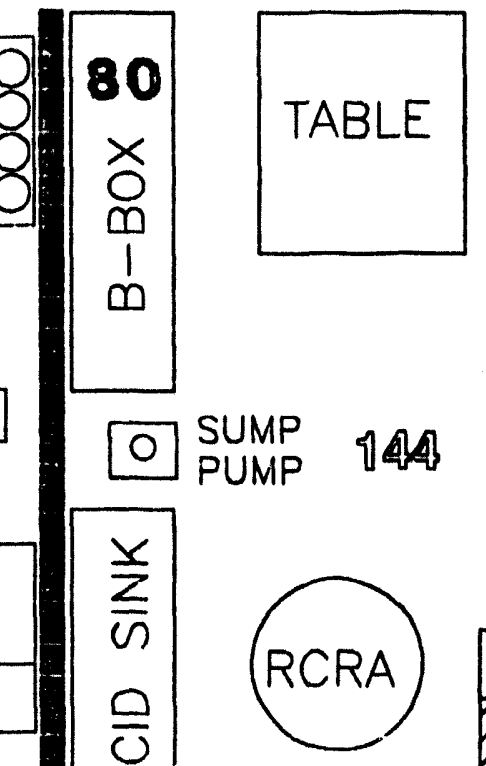

9 ACID
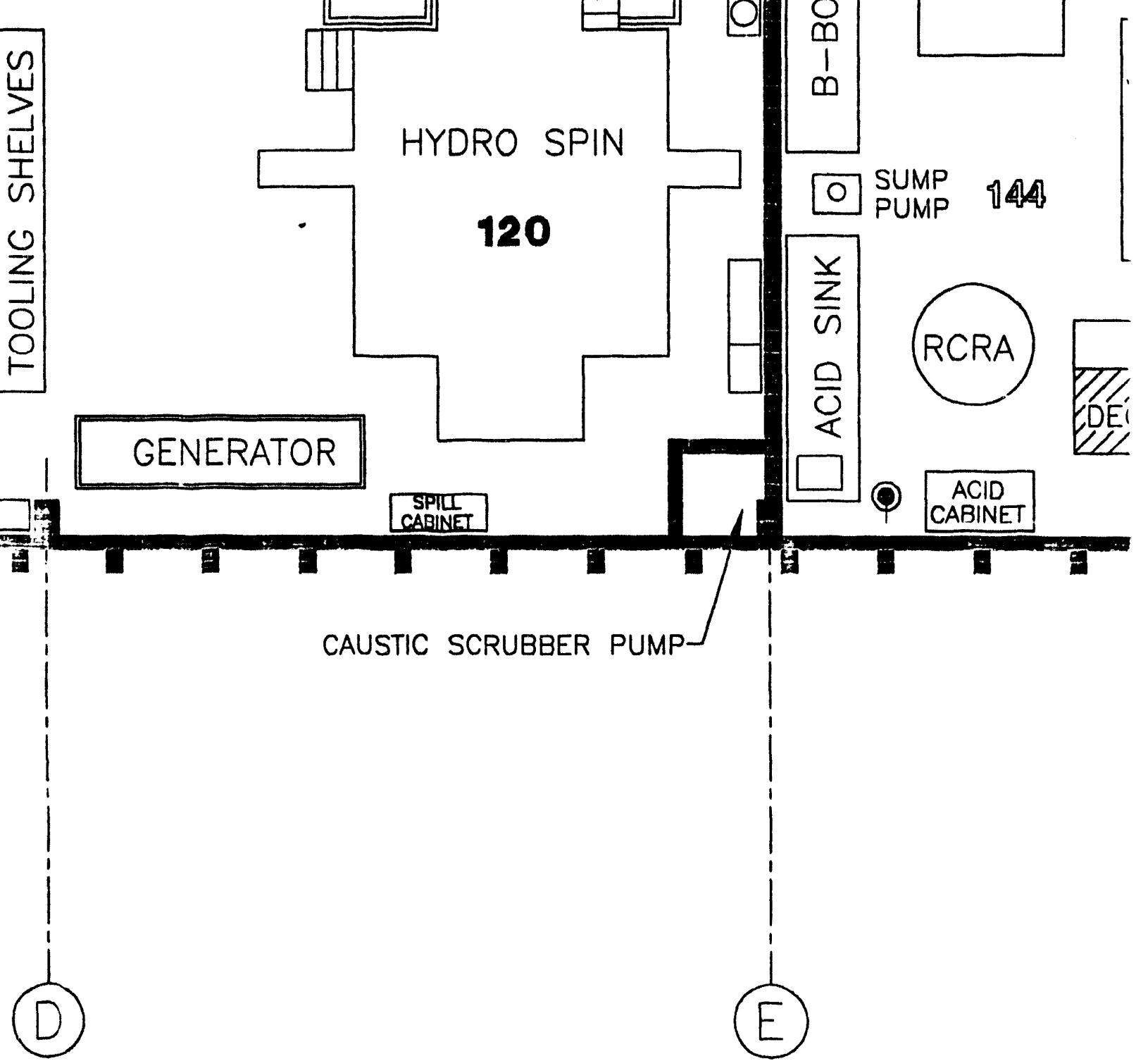

\section{KEY}

1) FILLED NUMBERS INDICATE THE REFERENCE ER OF EQUIPMENT.

G!: 


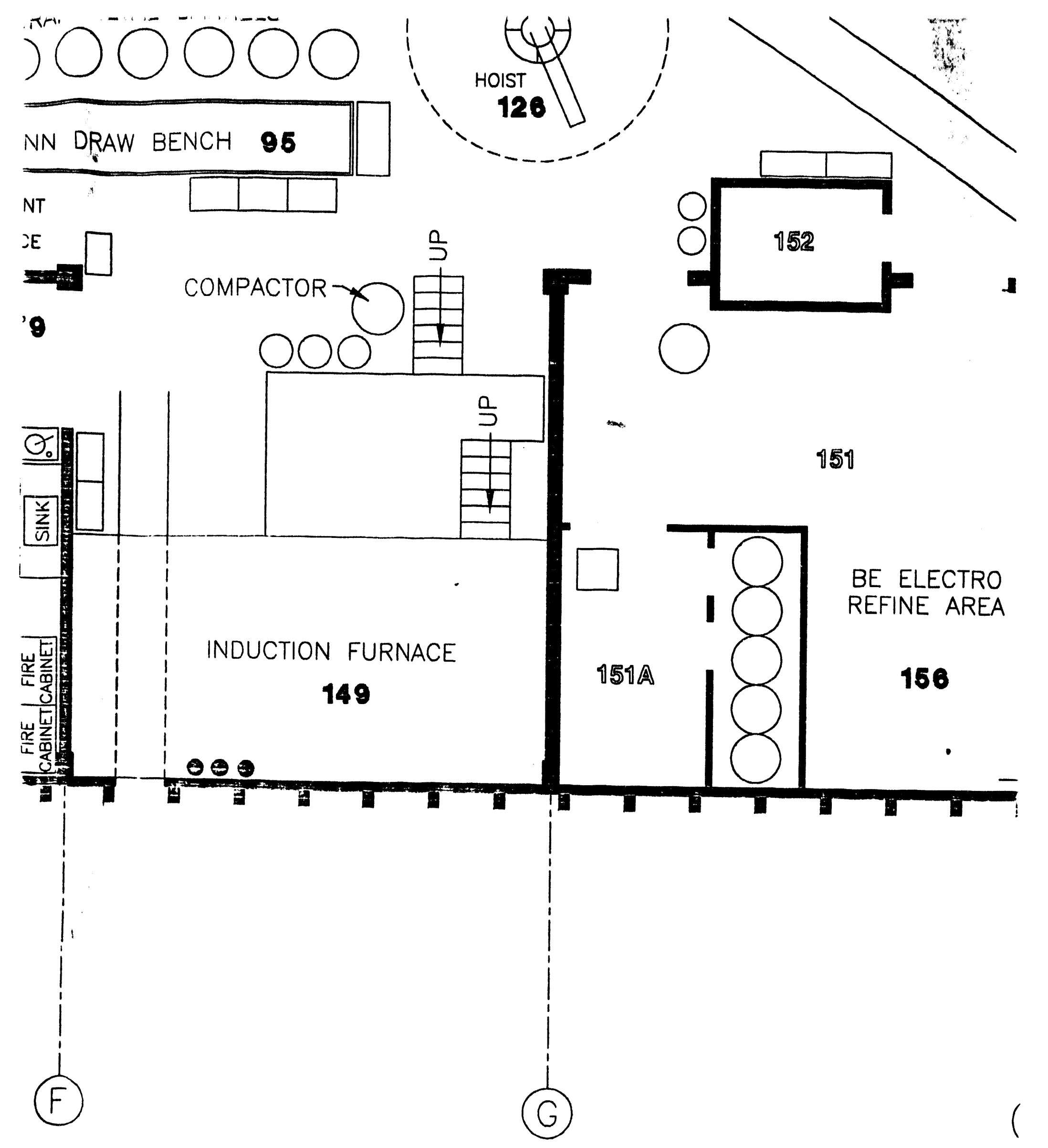




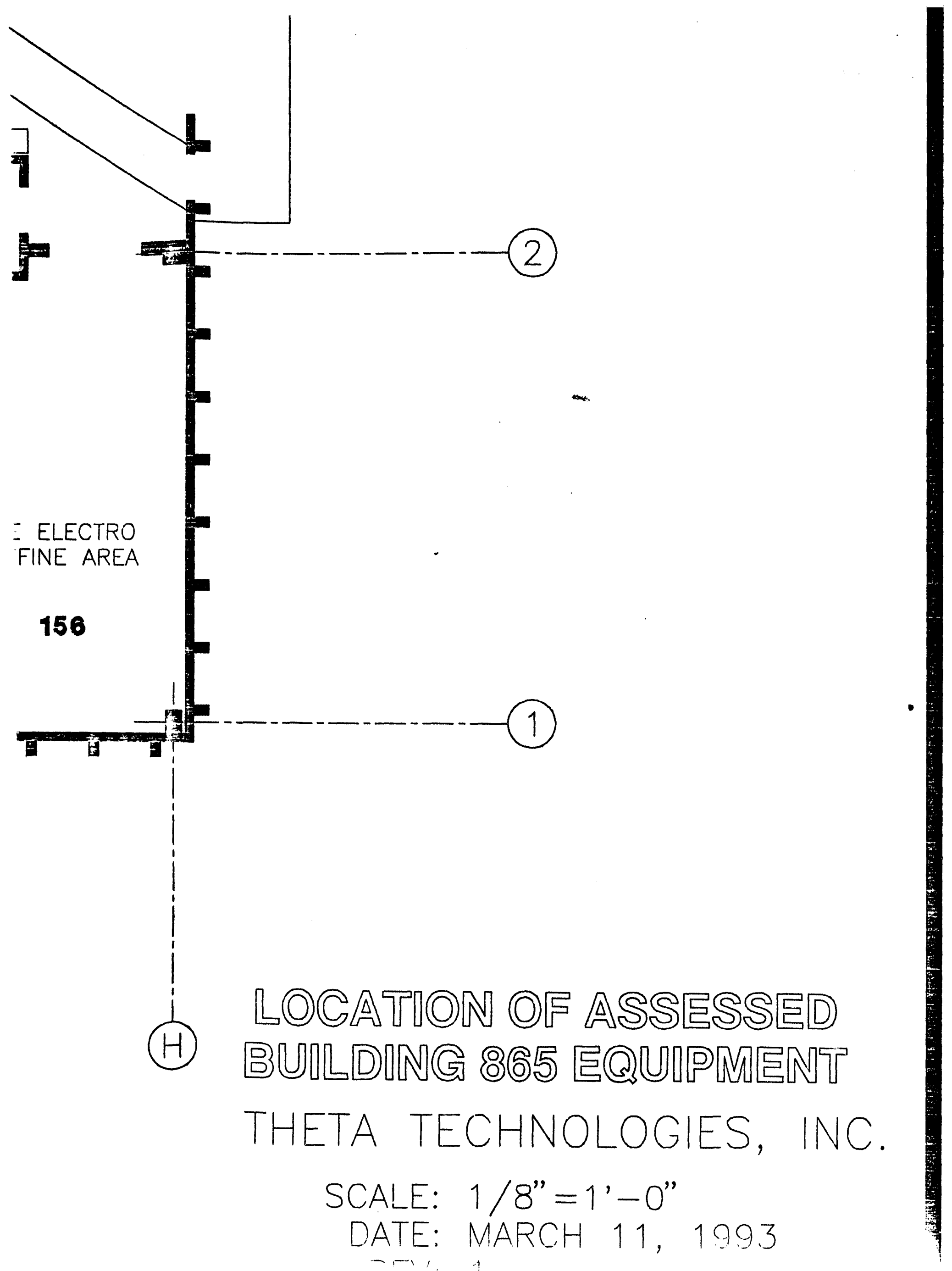




\section{B.2 Baseline Cost Data Output}

Baseline cost data, generated by the system based on input parameters, includes pertinent cost information for each piece of equipment. This information includes: Item number, manufacturer, description, oil drain and flush cost, removal labor cost, sealand cost, and landfill fees, both commercial and government. 
Page: 1

\begin{tabular}{|c|c|c|c|c|c|c|}
\hline$\frac{1 \text { te }}{6}$ Manfecturer & Description & $\begin{array}{l}0 \text { oil Drain } \\
\text { Flush } \\
30.00\end{array}$ & $\begin{array}{l}\begin{array}{l}\text { Removal } \\
\text { Lebor Cost }\end{array} \\
30.00\end{array}$ & $\frac{\text { Seal and Cost }}{\$ 0.00}$ & $\begin{array}{l}\text { Londf ill } \\
\frac{\text { Govt }}{30.00}\end{array}$ & $\begin{array}{l}\text { Fees } \\
\frac{\mathrm{Co}_{\mathrm{m}}}{50.00}\end{array}$ \\
\hline 2 Nikon & Camera & 50.00 & $\$ 233.00$ & $\$ 153.00$ & $\$ 256.00$ & $\$ 10240.00$ \\
\hline 3 Polaroid & Camera and Light Table & 50.00 & $\$ 233.00$ & $\$ 306.00$ & $\$ 512.00$ & $\$ 20480.00$ \\
\hline 4 vickers & Projection Microscope & 90.00 & $\$ 233.00$ & $\$ 114.75$ & $\$ 192.00$ & $\$ 7680.00$ \\
\hline 5 Basch 2 Loub & Metall lograph & 50.00 & $\$ 466.00$ & $\$ 153.00$ & $\$ 256.00$ & $\$ 10240.00$ \\
\hline 6 Leco & Metal lograph & 10.00 & $\$ 233.00$ & $\$ 153.00$ & $\$ 256.00$ & $\$ 10240.00$ \\
\hline 7 vilson & Microhardhess Tester & $\$ 0.00$ & $\$ 233.00$ & $\$ 114.75$ & $\$ 192.00$ & $\$ 7680.00$ \\
\hline 8 Buehter & Microhardhess Tester & $\$ 0.00$ & $\$ 466.00$ & $\$ 114.75$ & $\$ 192.00$ & $\$ 7680.00$ \\
\hline 9 vilson & Microhardhess Tester & $\$ 0.00$ & $\$ 233.00$ & $\$ 114.75$ & $\$ 192.00$ & $\$ 7680.00$ \\
\hline 10 Theta & Dilatometer & $\$ 0.00$ & $\$ 699.00$ & $\$ 306.00$ & $\$ 512.00$ & $\$ 20480.00$ \\
\hline 11 Automet & Automet/Evromet Pol isher & $\$ 0.00$ & $\$ 466.00$ & $\$ 229.50$ & $\$ 384.00$ & $\$ 15360.00$ \\
\hline 11 Lepel & RF Generator & $\$ 0.00$ & $\$ 2946.00$ & $\$ 0.00$ & $\$ 0.00$ & 50.00 \\
\hline 12 Leco & Diemond seurs (2 each) & $\$ 0.00$ & $\$ 466.00$ & $\$ 153.00$ & $\$ 256.00$ & $\$ 10240.00$ \\
\hline 13 Newage & Rockwell Mardhess Tester & 50.00 & $\$ 233.00$ & $\$ 114.75$ & $\$ 192.00$ & $\$ 7680.00$ \\
\hline 16 Riehle & Rockmell Mardness Tester & 50.00 & $\$ 233.00$ & $\$ 114.75$ & $\$ 192.00$ & $\$ 7680.00$ \\
\hline 15 Clark Instr. Co & Rockwell Mardhess Tester & 80.00 & $\$ 233.00$ & $\$ 114.75$ & $\$ 192.00$ & $\$ 7680.00$ \\
\hline $16 \mathrm{milson} /$ Rockmell & Rockwell Mardhess Tester & 50.00 & $\$ 233.00$ & $\$ 114.75$ & $\$ 192.00$ & $\$ 7680.00$ \\
\hline 17 & Moods (2 each) & 50.00 & $\$ 932.00$ & $\$ 1147.50$ & $\$ 1920.00$ & $\$ 76800.00$ \\
\hline 18 Jarrett & Jarrett Polisher & 50.00 & 2466.00 & $\$ 153.00$ & $\$ 256.00$ & $\$ 10240.00$ \\
\hline 19 Leco & Grinder w/ Lood Controller & 50.00 & $\$ 466.00$ & $\$ 153.00$ & $\$ 256.00$ & $\$ 10240.00$ \\
\hline 20 Buchler & Maximet Grinder & 80.00 & $\$ 233.00$ & 5114.75 & $\$ 192.00$ & $\$ 7680.00$ \\
\hline 21 & Polimet (3 each) grinding in & 50.00 & $\$ 233.00$ & $\$ 114.75$ & $\$ 192.00$ & $\$ 7680.00$ \\
\hline 22 & 12ü Pol imet Grinder & $\$ 0.00$ & $\$ 233.00$ & $\$ 114.75$ & $\$ 192.00$ & $\$ 7680.00$ \\
\hline 23 Buehler & Abrasinet saw & $\$ 0.00$ & $\$ 233.00$ & $\$ 114.75$ & $\$ 192.00$ & $\$ 7680.00$ \\
\hline 24 Instron & Test Machine and Controller & $\$ 0.00$ & $\$ 466.00$ & $\$ 153.00$ & $\$ 256.00$ & $\$ 10240.00$ \\
\hline 25 Buehler & Pneumet Mounting Press & $\$ 0.00$ & $\$ 466.00$ & $\$ 3344.25$ & $\$ 576.00$ & $\$ 23040.00$ \\
\hline 26 & Sink Mounted Press (2) & 50.00 & $\$ 233.00$ & $\$ 153.00$ & $\$ 256.00$ & $\$ 10240.00$ \\
\hline 27 mis & Test Machine & $\$ 0.00$ & $\$ 233.00$ & $\$ 15.30$ & $\$ 25.60$ & $\$ 1024.00$ \\
\hline
\end{tabular}




\begin{tabular}{|c|c|c|c|c|c|c|}
\hline$\frac{\text { ten }}{20} \frac{\text { Menifecturer }}{\text { iTS }}$ & $\frac{\text { Deseription }}{\text { Test Machine }}$ & $\begin{array}{c}0 \text { Oil Drain/ } \\
\text { Flush } \\
50.00\end{array}$ & $\begin{array}{l}\begin{array}{c}\text { Removal } \\
\text { Labor Cost }\end{array} \\
\$ 233.00\end{array}$ & $\frac{\text { Seal and Cost }}{315.30}$ & $\begin{array}{l}\text { - Landfill } \\
\frac{\text { Govt }}{\$ 25.60}\end{array}$ & $\begin{array}{l}\text { Fees } \\
\frac{\text { Con }}{51024.00}\end{array}$ \\
\hline 29 Euchler & Pollimet grinders & 50.00 & $\$ 233.00$ & 5114.75 & $\$ 192.00$ & $\$ 7680.00$ \\
\hline 30 Buehter & Vibramet Pol isher & 80.00 & $\$ 233.00$ & 8114.75 & $\$ 192.00$ & $\$ 7680.00$ \\
\hline 31 Buchler & Uleramet iv & 50.00 & $\$ 233.00$ & $\$ 114.75$ & $\$ 192.00$ & $\$ 7680.00$ \\
\hline 32 Buchler & Vibromet 1 & 50.00 & $\$ 233.00$ & $\$ 114.75$ & $\$ 192.00$ & $\$ 7680.00$ \\
\hline 33 Lepel & RF Generator & 50.00 & $\$ 233.00$ & $\$ 114.75$ & $\$ 192.00$ & $\$ 7680.00$ \\
\hline 34 Powermatic & Bend Saw & 50.00 & $\$ 233.00$ & $\$ 229.50$ & $\$ 384.00$ & $\$ 15360.00$ \\
\hline 35 & Bridseport Mill & 5404.90 & $\$ 1730.00$ & $\$ 1644.75$ & $\$ 2752.00$ & 3110080.00 \\
\hline 36 Rockwell & Hardness Tester & 50.00 & $\$ 233.00$ & $\$ 114.75$ & $\$ 192.00$ & $\$ 7680.00$ \\
\hline 37 Buehler & Grinder Pol isher & 50.00 & $\$ 432.50$ & $\$ 114.75$ & $\$ 192.00$ & $\$ 7680.00$ \\
\hline 38 Rockwell/Del to & Drill Press & 50.00 & $\$ 216.25$ & $\$ 344.25$ & $\$ 576.00$ & $\$ 23040.00$ \\
\hline 39 & Grinder & $\$ 0.00$ & $\$ 216.25$ & $\$ 841.50$ & $\$ 1408.00$ & $\$ 56320.00$ \\
\hline 40 Pratt 2 mitney & 12" Lathe & $\$ 609.80$ & $\$ 1730.00$ & $\$ 612.00$ & $\$ 1024.00$ & $\$ 40960.00$ \\
\hline 41 Pexto Beverly & Hand Operated Shear & $\$ 0.00$ & $\$ 233.00$ & $\$ 45.90$ & $\$ 76.80$ & $\$ 3072.00$ \\
\hline 42 Dreis \& Krup & Sheet Wetal Bender - 36" & $\$ 0.00$ & $\$ 466.00$ & $\$ 61.20$ & $\$ 102.40$ & $\$ 4096.00$ \\
\hline 43 & Tool Crib & 50.00 & $\$ 0.00$ & $\$ 0.00$ & $\$ 0.00$ & $\$ 0.00$ \\
\hline 4h sureweld & Welder & $\$ 0.00$ & $\$ 466.00$ & $\$ 122.40$ & $\$ 204.80$ & $\$ 8192.00$ \\
\hline $4500-A 11$ & Band Sau & $\$ 643.95$ & $\$ 865.00$ & $\$ 1530.00$ & $\$ 2560.00$ & $\$ 102400.00$ \\
\hline 46 Rockwell & Belt sender & $\$ 268.30$ & $\$ 1730.00$ & $\$ 114.75$ & $\$ 192.00$ & $\$ 7680.00$ \\
\hline 47 Bridseport & Milling Machine & $\$ 268.30$ & $\$ 1730.00$ & $\$ 1683.00$ & $\$ 2816.00$ & $\$ 112640.00$ \\
\hline 48 Bridgeport & Milling Machine & $\$ 268.30$ & $\$ 1730.00$ & $\$ 1683.00$ & $\$ 2816.00$ & $\$ 112640.00$ \\
\hline 49 Bridseport & Milling Machine & $\$ 268.30$ & $\$ 1730.00$ & $\$ 1683.00$ & $\$ 2816.00$ & $\$ 112640.00$ \\
\hline 50 8ridgeport & Mflling Nochine & $\$ 917.15$ & $\$ 1730.00$ & $\$ 1683.00$ & $\$ 2816.00$ & $\$ 112640.00$ \\
\hline 51 Bridgeport & Milling Machine & 5404.90 & $\$ 1730.00$ & $\$ 1912.50$ & $\$ 3200.00$ & $\$ 128000.00$ \\
\hline 52 Cimcinati & Milling Machine & $\$ 678.10$ & $\$ 1730.00$ & $\$ 2756.00$ & $\$ 4608.00$ & $\$ 184320.00$ \\
\hline 53 Aberboga Maskim & Drill Press & $\$ 0.00$ & $\$ 233.00$ & $\$ 30.60$ & $\$ 51.20$ & $\$ 2048.00$ \\
\hline 54 AL2 Metall & Drill Press & $\$ 473.20$ & $\$ 466.00$ & $\$ 364.25$ & $\$ 576.00$ & $\$ 235,40.00$ \\
\hline 55 Uolker-Turner & Drill Press & $\$ 2658.80$ & $\$ 466.00$ & $\$ 175.95$ & $\$ 294.40$ & $\$ 11776.00$ \\
\hline
\end{tabular}




\begin{tabular}{|c|c|c|c|c|c|c|}
\hline 1tee Monfacturer & $\frac{\text { Description }}{\text { Drill sharpener }}$ & $\begin{array}{l}\text { Oil Drain/ } \\
\frac{\text { Flush }}{50.00}\end{array}$ & $\begin{array}{l}\text { Removal } \\
\text { lebor Cost } \\
233.00\end{array}$ & $\frac{\text { Seal and Cost }}{\$ 30.60}$ & $\begin{array}{l}\text { G Landfill } \\
\text { Govt } \\
\$ 51.20\end{array}$ & Fees \\
\hline 57 Leslond & Engine Lathe & $\$ 746.40$ & $\$ 1730.00$ & $\$ 1025.10$ & $\$ 1715.20$ & 868608.00 \\
\hline 58 Monerch & Engine Lathe, $16 \times \times 30^{m}$ & $\$ 766.40$ & $\$ 1730.00$ & $\$ 833.85$ & $\$ 1395.20$ & $\$ 55808.00$ \\
\hline 59 Monerch & Engine Lathe, 16 inch & $\$ 1566.00$ & $\$ 1730.00$ & $\$ 841.50$ & $\$ 1408.00$ & $\$ 56320.00$ \\
\hline 60 Monarch & Engine Lathe, 20 inch & $\$ 1429.40$ & $\$ 1730.00$ & $\$ 1147.50$ & $\$ 1920.00$ & $\$ 76800.00$ \\
\hline 61 Monarch & Engine Lothe, 60 inch & $\$ 1087.90$ & $\$ 1730.00$ & $\$ 841.50$ & $\$ 1408.00$ & $\$ 56320.00$ \\
\hline 62 Racine & Heck Saw, 14 inch & $\$ 404.90$ & $\sec 5.00$ & $\$ 153.00$ & $\$ 256.00$ & $\$ 10240.00$ \\
\hline 63 Bleck \& Decker & Pedestal Grinder & 8404.90 & $\$ 233.00$ & 561.20 & $\$ 102.40$ & $\$ 4096.00$ \\
\hline 64 Hemmond & Pedestal Grinder & $\$ 234.15$ & $\$ 233.00$ & $\$ 153.00$ & $\$ 256.00$ & $\$ 10260.00$ \\
\hline 65 Baldor & Pedestal Grinder-Buffer & 50.00 & $\$ 233.00$ & $\$ 53.55$ & $\$ 89.60$ & $\$ 3584.00$ \\
\hline 66 Brom 2 Sharpe & Surface Grinder 618 Micro & $\$ 712.25$ & $\$ 865.00$ & $\$ 818.55$ & $\$ 1369.60$ & $\$ 54784.00$ \\
\hline 67 Cutter Master & Tool Grinder & 50.00 & $\$ 233.00$ & $\$ 45.90$ & $\$ 76.80$ & $\$ 3072.00$ \\
\hline 68 Mardinge & Tool Room Lothe & $\$ 507.35$ & $\$ 1730.00$ & $\$ 459.00$ & $\$ 768.00$ & $\$ 30720.00$ \\
\hline 69 Mardinge & Tool Room Lathe & 5507.35 & $\$ 1730.00$ & $\$ 459.00$ & $\$ 768.00$ & $\$ 30720.00$ \\
\hline 70 Mardinge & rool Roon Lathe & $\$ 507.35$ & $\$ 1730.00$ & $\$ 459.00$ & $\$ 768.00$ & $\$ 30720.00$ \\
\hline 71 Mardinge & Tool Room Lathe & $\$ 507.35$ & $\$ 1730.00$ & $\$ 459.00$ & $\$ 768.00$ & $\$ 30720.00$ \\
\hline 72 sullord & Vertical Turret Lathe & 84639.50 & $\$ 35328.00$ & $\$ 16830.00$ & $\$ 28160.00$ & 1126400.00 \\
\hline 73 & Air Compressor & 50.00 & 50.00 & $\$ 0.00$ & 50.00 & 50.00 \\
\hline 74 & Power Switches & 50.00 & 50.00 & $\$ 0.00$ & 50.00 & 50.00 \\
\hline 75 & Pums & 50.00 & $\$ 0.00$ & 50.00 & $\$ 0.00$ & $\$ 0.00$ \\
\hline 76 & stean supply & 50.00 & 90.00 & 50.00 & $\$ 0.00$ & $\$ 0.00$ \\
\hline$\pi$ & Woter Meader & 50.00 & 50.00 & 50.00 & 50.00 & 50.00 \\
\hline 78 & Water Recirculator & $\$ 0.00$ & $\$ 0.00$ & 50.00 & $\$ 0.00$ & $\$ 0.00$ \\
\hline 79 & RPT office & $\$ 0.00$ & 50.00 & 50.00 & 50.00 & 50.00 \\
\hline 80 Buchler & Abrasive Cutoff San (Small) & $\$ 0.00$ & $\$ 865.00$ & $\$ 306.00$ & $\$ 512.00$ & $\$ 20480.00$ \\
\hline 81 Mone & Be Preparation úsù Box & 50.00 & $\$ 736.00$ & $\$ 864.45$ & $\$ 1446.40$ & $\$ 57856.00$ \\
\hline 82 Detrex & Degreaser & 50.00 & $\$ 736.00$ & $\$ 1912.50$ & $\$ 3200.00$ & $\$ 128000.00$ \\
\hline 83 milwaukee & Grinder & $\$ 0.00$ & $\$ 233.00$ & $\$ 306.00$ & $\$ 512.00$ & $\$ 20480.00$ \\
\hline
\end{tabular}




\begin{tabular}{|c|c|c|c|c|c|c|}
\hline$\frac{1 t e}{84}$ Henufecturer & $\frac{\text { Description }}{\text { Sinks (2 eech) }}$ & $\begin{array}{l}\text { Oil Drain/ } \\
\frac{\text { Flush }}{\$ 0.00}\end{array}$ & $\begin{array}{l}\text { Removal } \\
\text { Labor Cost } \\
\$ 466.00\end{array}$ & $\frac{\text { Seal and Cost }}{\$ 459.00}$ & $\begin{array}{l}\text { Lendfill } \\
\text { Govt } \\
\$ 768.00\end{array}$ & Fees \\
\hline 85 Lindberg & Tube Furnace \& Evac. Ass'y. & 50.00 & $\$ 587.50$ & $\$ 535.50$ & $\$ 896.00$ & $\$ 35840.00$ \\
\hline 86 Continental & Abrasive Cut-off $\mathrm{Sam}, 36$ inc & 50.00 & $\$ 1730.00$ & $\$ 4819.50$ & 58064.00 & $\$ 322560.00$ \\
\hline 87 Nobart & Battery Charger (3 each) & 50.00 & 50.00 & 50.00 & 50.00 & $\$ 0.00$ \\
\hline 88 Mone & Be Glovebox, inert & $\$ 0.00$ & $\$ 736.00$ & $\$ 5125.50$ & $\$ 8576.00$ & $\$ 343040.00$ \\
\hline 89 Diversified Met & Be Preparation Box & 50.00 & $\$ 736.00$ & $\$ 2065.50$ & $\$ 3456.00$ & $\$ 138240.00$ \\
\hline 90 Mi lwoukee & Bench Grinder & $\$ 0.00$ & $\$ 233.00$ & $\$ 306.00$ & $\$ 512.00$ & 320480.00 \\
\hline 91 Thernolye & Box Furnace & 50.00 & $\$ 1730.00$ & $\$ 382.50$ & $\$ 640.00$ & $\$ 25600.00$ \\
\hline 92 Thermolyme & Box Furnace & 50.00 & $\$ 1730.00$ & $\$ 382.50$ & $\$ 640.00$ & $\$ 25600.00$ \\
\hline 93 Lindberg & Box Furnece, Sola Basic 6" $x$ & 80.00 & $\$ 865.00$ & $\$ 76.50$ & $\$ 128.00$ & $\$ 5120.00$ \\
\hline 96 Pexto & Circle shear & $\$ 234.15$ & $\$ 432.50$ & $\$ 153.00$ & $\$ 256.00$ & $\$ 10240.00$ \\
\hline 95 Barrett Powerox & Die stacker & $\$ 336.60$ & $\$ 865.00$ & $\$ 918.00$ & $\$ 1536.00$ & $\$ 61440.00$ \\
\hline 96 Fern & Drw Bench & $\$ 3615.00$ & $\$ 2350.00$ & $\$ 4207.50$ & $\$ 7040.00$ & $\$ 281600.00$ \\
\hline 97 Lelend Gifford & Drill Press & $\$ 302.45$ & $\$ 865.00$ & $\$ 765.00$ & $\$ 1280.00$ & $\$ 51200.00$ \\
\hline 98 rockwell mil. & Drill Press & $\$ 0.00$ & $\$ 233.00$ & $\$ 76.50$ & $\$ 128.00$ & $\$ 5120.00$ \\
\hline 99 Leybold-Meraeus & Electron Beem Furnace & $\$ 1634.30$ & $\$ 23500.00$ & $\$ 21420.00$ & $\$ 35840.00$ & 1433600.00 \\
\hline 100 sutton & 2000 Ton Extrusion Press & $\$ 75330.00$ & $\$ 29440.00$ & $\$ 93636.00$ & $\$ 156672.00$ & 6266880.00 \\
\hline 101 Autcomatic & Fork Truck & $\$ 0.00$ & $\$ 0.00$ & 50.00 & 50.00 & 50.00 \\
\hline 102 Lewis-shepard & 2000 lb Cep fork Truck & $\$ 0.00$ & $\$ 0.00$ & 50.00 & 50.00 & $\$ 0.00$ \\
\hline 103 Alt is Chalmers & 4000 lb Cap Fork Truck & $\$ 0.00$ & $\$ 0.00$ & 50.00 & $\$ 0.00$ & 50.00 \\
\hline 104 Lindberg & Furnace & $\$ 234.15$ & $\$ 14100.00$ & $\$ 8262.00$ & $\$ 13824.00$ & $\$ 552960.00$ \\
\hline 105 Lindberg & Furnoce & $\$ 234.15$ & $\$ 14100.00$ & $\$ 8262.00$ & $\$ 13824.00$ & $\$ 552960.00$ \\
\hline 106 Despatch & 1450 F Furnace, $20 \mathrm{kH}$ & $\$ 234.15$ & $\$ 11750.00$ & $\$ 1377.00$ & $\$ 2304.00$ & $\$ 92160.00$ \\
\hline 107 frees & Furnace & $\$ 0.00$ & $\$ 9400.00$ & $\$ 229.50$ & $\$ 384.00$ & $\$ 15360.00$ \\
\hline 108 Marper Pit Furn & 1500 c Electric furnace & $\$ 234.15$ & $\$ 9400.00$ & $\$ 3366.00$ & $\$ 5632.00$ & $\$ 225280.00$ \\
\hline 109 Vecuen Industri & Furnace & 5643.95 & $\$ 7050.00$ & $\$ 3901.50$ & $\$ 6528.00$ & $\$ 261120.00$ \\
\hline 110 Lindberg & $1370 \mathrm{c}, 95 \mathrm{~kW}$, furnece & $\$ 234.15$ & $\$ 11750.00$ & $\$ 6426.00$ & $\$ 10752.00$ & 5430080.00 \\
\hline 111 Norton & Furnace, $\mathrm{Hi}$-temp. & 50.00 & $\$ 466.00$ & $\$ 1836.00$ & $\$ 3072.00$ & $\$ 122880.00$ \\
\hline
\end{tabular}




\begin{tabular}{|c|c|c|c|c|c|c|}
\hline$\frac{\text { Ite }}{112} \frac{\text { Menufecturer }}{A \text { Bar }}$ & $\frac{\text { Description }}{1200 \text { C.Furnace, Migh Vacum }}$ & $\begin{array}{c}\text { Oil Drain/ } \\
\text { Flush } \\
\$ 746.60\end{array}$ & $\begin{array}{l}\text { Removal } \\
\text { Lebor Cost } \\
\$ 9400.00\end{array}$ & $\frac{\text { Sealend } \cos t}{510404.00}$ & $\begin{array}{l}\text { Lendfill } \\
\$ 1 \frac{\text { Govt }}{7408.00}\end{array}$ & $\begin{array}{l}\text { Fees } \\
\qquad 6960000 \\
56320.00\end{array}$ \\
\hline 113 A Bor & $1600 \mathrm{C}$, Vecum furnace & 2473.20 & $\$ 7050.00$ & $\$ 1300.50$ & $\$ 2176.00$ & $\$ 87040.00$ \\
\hline 114 Lindberg & Glass Tube Furnace & 50.00 & $\$ 1175.00$ & $\$ 153.00$ & $\$ 256.00$ & $\$ 10240.00$ \\
\hline 115 satec systems, & Gradient Bar Furnace & 50.00 & $\$ 1175.00$ & $\$ 229.50$ & $\$ 384.00$ & $\$ 15360.00$ \\
\hline 116 Liquid Moning & Grit Balster, liquid & $\$ 0.00$ & $\$ 1175.00$ & 3612.00 & $\$ 1024.00$ & $\$ 40960.00$ \\
\hline 117 Peerless & Mack Saw & 5917.15 & $\$ 865.00$ & $\$ 535.50$ & $\$ 896.00$ & $\$ 35840.00$ \\
\hline 118 Racine & Power Hack Sem & 5473.20 & $\$ 865.00$ & $\$ 1606.50$ & $\$ 2688.00$ & $\$ 107520.00$ \\
\hline 119 Recine & Mack Sew & $\$ 473.20$ & $\$ 285.00$ & $\$ 1606.50$ & $\$ 2688.00$ & $\$ 107520.00$ \\
\hline 120 Autocleve & Not Isostatic Press & $\$ 33871.90$ & $\$ 35328.00$ & $\$ 15300.00$ & $\$ 25600.00$ & 1024000.00 \\
\hline 121 Cincinatti & Mydrospin & $\$ 3615.00$ & $\$ 26496.00$ & $\$ 30600.00$ & $\$ 51200.00$ & 2048000.00 \\
\hline 122 Lepel & Induction coil & 50.00 & $\$ 865.00$ & $\$ 130.05$ & $\$ 217.60$ & $\$ 8704.00$ \\
\hline 123 Heraeus-Engleha & Induction furnace & 50.00 & $\$ 1175.00$ & $\$ 4590.00$ & $\$ 7680.00$ & $\$ 307200.00$ \\
\hline 124 continental & 36" Abrasive Cutoff Sem & $\$ 0.00$ & $\$ 1730.00$ & $\$ 4819.50$ & $\$ 8064.00$ & $\$ 322560.00$ \\
\hline 125 CEC & Leak Detector & 8236.15 & $\$ 865.00$ & $\$ 91.80$ & $\$ 153.60$ & $\$ 6144.00$ \\
\hline 126 Vorien & Leak Detector & $\$ 234.15$ & $\$ 865.00$ & $\$ 38.25$ & $\$ 64.00$ & $\$ 2560.00$ \\
\hline 127 Lift-A- Loft & 500 Lb Cepecity Lifter & $\$ 336.60$ & $\$ 233.00$ & $\$ 2210.85$ & $\$ 3699.20$ & $\$ 147968.00$ \\
\hline 128 CE of Cenede & Monmate & $\$ 2078.25$ & $\$ 865.00$ & $\$ 4054.50$ & 56724.00 & $\$ 271360.00$ \\
\hline 129 & Material storege & 80.00 & $\$ 0.00$ & $\$ 0.00$ & 50.00 & 50.00 \\
\hline 130 slue $n$ Elec. Co & Oil Bath Weater & $\$ 816.70$ & $\$ 865.00$ & $\$ 160.65$ & $\$ 268.80$ & $\$ 10752.00$ \\
\hline 131 Lindberg & Porteble Box Furnace & 90.00 & $\$ 233.00$ & $\$ 581.40$ & $\$ 972.80$ & $\$ 38912.00$ \\
\hline 132 Tinius olson & Press, 60,000 lbs. & $\$ 609.80$ & $\$ 865.00$ & $\$ 1285.20$ & $\$ 2150.40$ & $\$ 86016.00$ \\
\hline 133 Mone & Ouench Tonk & 50.00 & $\$ 265.00$ & $\$ 627.30$ & $\$ 1049.60$ & $\$ 41984.00$ \\
\hline 134 Peck, Stow, \& V & Roller, Former- 20 Ga. Cap. & $\$ 0.00$ & $\$ 865.00$ & $\$ 30.60$ & $\$ 51.20$ & $\$ 2048.00$ \\
\hline 135 stannet & Rolling Mill & $\$ 541.50$ & $\$ 6920.00$ & $\$ 887.40$ & $\$ 1484.80$ & $\$ 59392.00$ \\
\hline $136 \mathrm{Fem}$ & $70,18.4$ H.P. Rolling Mill & $\$ 234.15$ & $\$ 6920.00$ & $\$ 1002.15$ & $\$ 1676.80$ & $\$ 67072.00$ \\
\hline 137 United & Rolling Mill & $\$ 3615.00$ & $\$ 58880.00$ & $\$ 11475.00$ & $\$ 19200.00$ & $\$ 768000.00$ \\
\hline 138 Molden & Solt Bath & 50.00 & $\$ 865.00$ & $\$ 1989.00$ & $\$ 3328.00$ & $\$ 133120.00$ \\
\hline 139 Lindberg & Salt Bath & 50.00 & $\$ 865.00$ & $\$ 336.60$ & $\$ 563.20$ & $\$ 22528.00$ \\
\hline
\end{tabular}




\begin{tabular}{|c|c|c|c|c|c|c|}
\hline$\frac{1 t e}{140} \frac{\text { Menufecturer }}{\text { Diecro }}$ & $\frac{\text { Description }}{\text { Shear. }}$ & $\begin{array}{c}\text { Oil Drein } \\
\text { flush } \\
50.00\end{array}$ & $\begin{array}{l}\begin{array}{l}\text { Rewoval } \\
\text { Lebor Cost }\end{array} \\
\$ 466.00\end{array}$ & $\frac{\text { Seal and Cost }}{\$ 22.95}$ & $\begin{array}{l}\text { Lovt } \\
\frac{\text { Covt il }}{338.40}\end{array}$ & 1 Fees - \\
\hline 141 Lodpe I shipley & Shear, $5 / 8$ inch square $\times 6^{\circ}$ & $\$ 575.65$ & $\$ 1730.00$ & $\$ 3870.90$ & $\$ 6476.80$ & $\$ 259072.00$ \\
\hline 162 miller & Spot Welder, Resistance & $\$ 0.00$ & $\$ 865.00$ & $\$ 45.90$ & $\$ 76.80$ & $\$ 3072.00$ \\
\hline 143 viduar & stocker-Retriever & $\$ 234.15$ & $\$ 1730.00$ & $\$ 122.40$ & $\$ 204.80$ & $\$ 8192.00$ \\
\hline 144 Erie & Stean forging Hamer & $\$ 917.15$ & $\$ 35328.00$ & $\$ 32436.00$ & $\$ 54272.00$ & 2170880.00 \\
\hline $145 \mathrm{Fem}$ & Sweger & 90.00 & $\$ 865.00$ & $\$ 864.45$ & $\$ 1446.40$ & $\$ 57856.00$ \\
\hline 146 Fern & Swager, Large & $\$ 0.00$ & $\$ 865.00$ & $\$ 5163.75$ & $\$ 8640.00$ & $\$ 345600.00$ \\
\hline 167 & Tool ing storege & 50.00 & $\$ 0.00$ & 50.00 & 50.00 & 50.00 \\
\hline 148 Erie & Triple Action Press, 150 Ton & $\$ 10445.00$ & $\$ 17664.00$ & $\$ 11675.00$ & $\$ 19200.00$ & $\$ 768000.00$ \\
\hline 149 Brew & Vecunen Furnace & $\$ 2385.60$ & $\$ 1730.00$ & $\$ 5806.35$ & $\$ 9715.20$ & $\$ 3386608.00$ \\
\hline 150 Ajax Northrup & Vacum Induction furnace & $\$ 1258.65$ & $\$ 9400.00$ & $\$ 2195.55$ & $\$ 3673.60$ & $\$ 146946.00$ \\
\hline 151 & Woste Box Storege & 50.00 & 50.00 & 50.00 & $\$ 0.00$ & 50.00 \\
\hline 152 & Stepoff Pad & $\$ 0.00$ & 80.00 & 50.00 & 50.00 & 50.00 \\
\hline 153 Coulter Electro & Coulter Counter & $\$ 236.15$ & 2466.00 & $\$ 145.35$ & $\$ 243.20$ & 59728.00 \\
\hline 154 Vecun Specialt & Vecum Arc Melt furnace & $\$ 370.75$ & $\$ 16100.00$ & 247812.50 & $\$ 80000.00$ & 3200000.00 \\
\hline 155 Conwoy Pressure & Mot Isostatic Press & $\$ 234.15$ & $\$ 3660.00$ & $\$ 328.95$ & $\$ 550.40$ & $\$ 22016.00$ \\
\hline 156 Spencer Turbine & Mouse Vacun System & 50.00 & $\$ 865.00$ & $\$ 0.00$ & 50.00 & 50.00 \\
\hline 157 Wone & Be Electorefining & 50.00 & $\$ 2595.00$ & $\$ 535.50$ & 5896.00 & $\$ 35840.00$ \\
\hline 158 Marwood & Cold Isostatic Press & $\$ 1600.15$ & $\$ 41216.00$ & $\$ 3213.00$ & $\$ 5376.00$ & $\$ 215040.00$ \\
\hline 159 & Cas Bottle Recks & 20.20 & 50.00 & $\$ 0.00$ & 50.00 & 50.00 \\
\hline 160 & Inside Dock & $\$ 0.00$ & 50.00 & $\$ 0.00$ & 50.00 & 50.00 \\
\hline 161 Colinonoy & flame Spray \& Hood & 50.00 & $\$ 2350.00$ & $\$ 765.00$ & $\$ 1280.00$ & $\$ 51200.00$ \\
\hline 162 Empire & Grit Blester (Dual) & $\$ 234.15$ & $\$ 1730.00$ & $\$ 1193.40$ & $\$ 1996.80$ & $\$ 79872.00$ \\
\hline 163 & & 50.00 & 50.00 & $\$ 0.00$ & 50.00 & 50.00 \\
\hline 164 & & 50.00 & 50.00 & 50.00 & $\$ 0.00$ & 50.00 \\
\hline 165 & & 50.00 & 50.00 & $\$ 0.00$ & 50.00 & 50.00 \\
\hline 166 & & $\$ 0.00$ & 50.00 & 50.00 & 50.00 & 50.00 \\
\hline
\end{tabular}




\section{B.3 Recycle/Reuse Cost Data Output}

Recycle/reuse cost data, generated by the system based on input parameters, includes pertinent cost information for each piece of equipment. This information includes: Item number, manufacturer, description, oil drain and flush cost, removal labor cost, sealand cost, landfill fees (both commercial and government), decon cost, sales price, metal value, and processing cost. 
Cost Elements for Recycle/Reuse Al ternatives

Page: 1

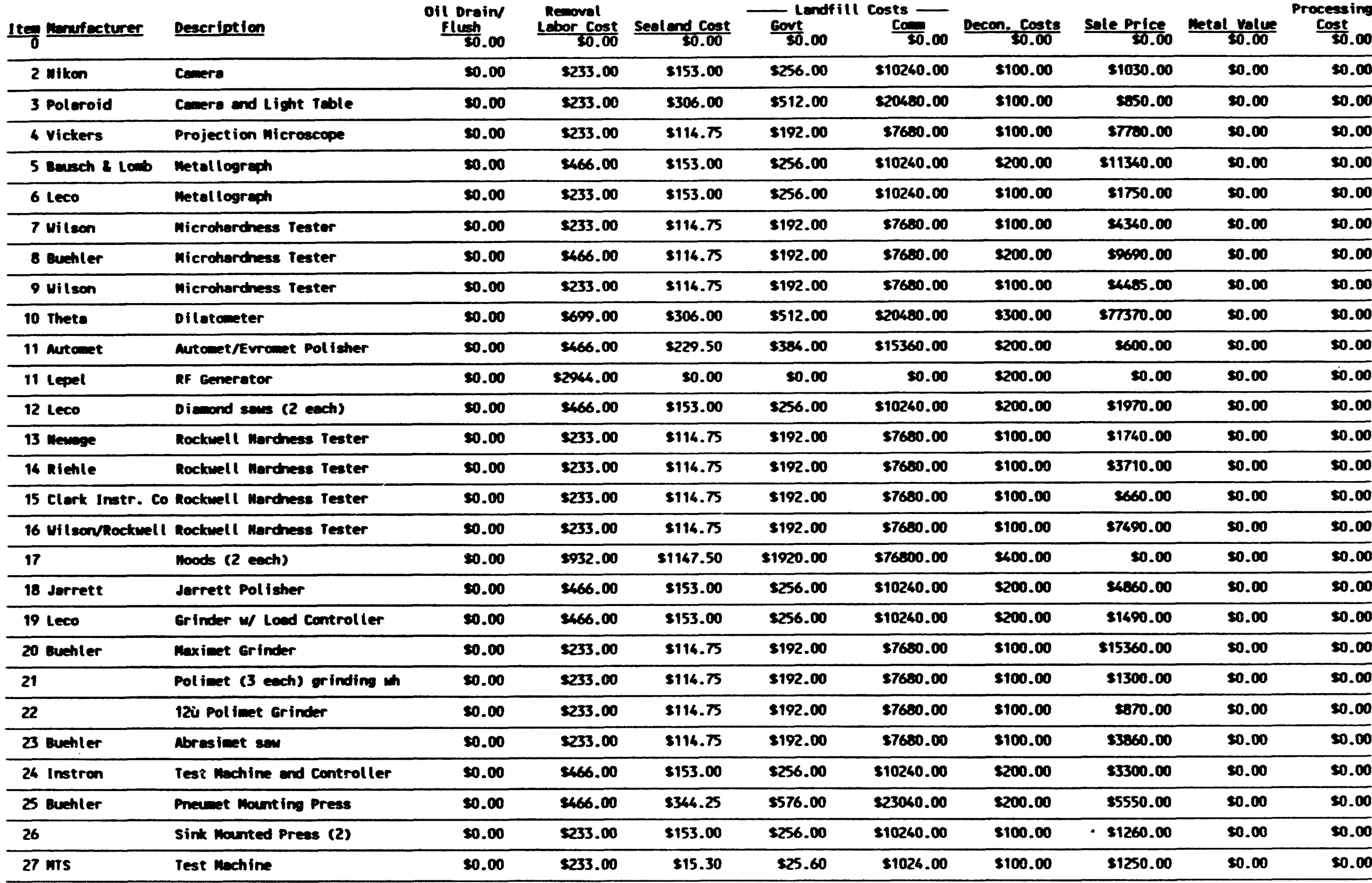


Cost Elements for Recycle/heuse Al ternotives

\begin{tabular}{|c|c|c|c|c|c|c|c|c|c|c|}
\hline 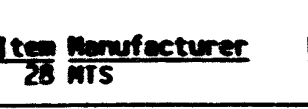 & $\frac{\text { Description }}{\text { Test inchine }}$ & $\begin{array}{l}0 \text { oil Drain } \\
\text { Flush } \\
\text { 50.00 }\end{array}$ & $\begin{array}{l}\begin{array}{c}\text { Removel } \\
\text { Lebor Cost }\end{array} \\
\$ 233.00\end{array}$ & $\frac{\operatorname{ses}(\text { end } \cos t}{315.30}$ & $\begin{array}{l}\text { Gond Lendi } \\
\frac{\text { Sovt }}{325.60}\end{array}$ & $\begin{array}{l}\cos t^{\cos }- \\
\frac{\frac{0}{1024} .00}{100}\end{array}$ & $\frac{\operatorname{Decon}, \operatorname{Costs}}{3100.00}$ & $\frac{\text { Sale Price }}{31250.00}$ & $\frac{\text { netal velue }}{\$ 0.00}$ & $\begin{array}{l}\text { Processing } \\
\frac{\text { Cost }}{50.00}\end{array}$ \\
\hline 29 Euchler & Pol inet grinders & 90.00 & $\$ 233.00$ & $\$ 114.75$ & 5192.00 & 87600.00 & $\$ 100.00$ & $\$ 1230.00$ & $\$ 0.00$ & 50.00 \\
\hline 30 Buehter & Vibroset Pollisher & 50.00 & $\$ 233.00$ & 5114.75 & $\$ 192.00$ & $\$ 7600.00$ & 5100.00 & 8640.00 & 90.00 & 90.00 \\
\hline 31 suehter & ut tranet IV & 50.00 & $\$ 233.00$ & 5114.75 & $\$ 192.00$ & $\$ 7680.00$ & $\$ 100.00$ & $\operatorname{sec0.00}$ & 90.00 & 90.00 \\
\hline 32 ouchler & vibromet 1 & $\$ 0.00$ & $\$ 233.00$ & $\$ 116.75$ & $\$ 192.00$ & $\$ 7600.00$ & $\$ 100.00$ & $\$ 2060.00$ & $\$ 0.00$ & 80.00 \\
\hline 33 Lepel & RF Generetor & 50.00 & $\$ 233.00$ & $\$ 116.75$ & $\$ 192.00$ & $\$ 7600.00$ & $\$ 100.00$ & 90.00 & 90.00 & 50.00 \\
\hline 36 Powernetic & Eand Sen & 90.00 & $\$ 233.00$ & $\$ 229.50$ & $\$ 384.00$ & $\$ 15360.00$ & 5700.75 & 55500.00 & $\$ 203.00$ & $\$ 2313.00$ \\
\hline 35 & Bridseport mill & 2404.90 & $\$ 1730.00$ & 51666.75 & $\$ 2752.00$ & 5110000.00 & 5945.00 & $\$ 2600.00$ & $\$ 745.00$ & 55676.00 \\
\hline 36 Rockwell & Mardhess Tester & 50.00 & $\$ 233.00$ & $\$ 114.75$ & $\$ 192.00$ & $\$ 7600.00$ & $\$ 100.00$ & $\$ 1500.00$ & 50.00 & 50.00 \\
\hline 37 avehler & Grinder Pollisher & 50.00 & 8432.50 & 5114.75 & $\$ 192.00$ & $\$ 7600.00$ & 2405.00 & 56000.00 & $\$ 146.00$ & 51035.00 \\
\hline 38 rockwell/pelts & Drill Press & 50.00 & $\$ 216.25$ & 8344.25 & $\$ 576.00$ & $\$ 23040.00$ & $\$ 156.60$ & $\$ 1200.00$ & 5138.00 & $\$ 1125.00$ \\
\hline 39 & Grinder & 50.00 & 2216.25 & 5841.50 & $\$ 1408.00$ & $\$ 56320.00$ & $\$ 369.90$ & $\$ 000.00$ & $\sin 2.00$ & $\$ 3570.00$ \\
\hline 40 Pratt 2 Whitney & 12" Lothe & 8609.80 & $\$ 1730.00$ & $\$ 612.00$ & $\$ 1026.00$ & 840960.00 & $\$ 337.50$ & $\$ 14000.00$ & $\$ 726.00$ & $\$ 5520.00$ \\
\hline 61 Pexto Deverly & Ind operoted sheer & 90.00 & $\$ 233.00$ & $\$ 45.90$ & $\$ 76.80$ & $\$ 3072.00$ & 5100.00 & $\$ 1600.00$ & 881.00 & 8625.00 \\
\hline 42 Dreis \& Krup & Sheet Metal Dender - 36" & $\$ 0.00$ & $\$ 466.00$ & $\$ 61.20$ & $\$ 102.40$ & $\$ 4096.00$ & $\$ 200.00$ & $\$ 1500.00$ & 501.00 & 2625.00 \\
\hline 43 & Tool Crib & 90.00 & 90.00 & $\$ 0.00$ & 50.00 & $\$ 0.00$ & 90.00 & 50.00 & $\$ 0.00$ & 50.00 \\
\hline 46 surewetd & Welder & $\$ 0.00$ & 2466.00 & $\$ 122.40$ & $\$ 204.80$ & $\$ 8192.00$ & $\$ 200.00$ & $\$ 1000.00$ & $\$ 0.00$ & 50.00 \\
\hline 65 Do-Al! & Band Sen & $\$ 643.95$ & 5865.00 & $\$ 1530.00$ & $\$ 2560.00$ & $\$ 102400.00$ & $55 \% .00$ & $\$ 10140.00$ & $\$ 703.00$ & $\$ 5950.00$ \\
\hline 46 Rockwell & Belt Sonder & $\$ 268.30$ & $\$ 1730.00$ & $\$ 114.75$ & $\$ 192.00$ & $\$ 7600.00$ & 5945.00 & $\$ 1100.00$ & $\$ 130.00$ & $\$ 1125.00$ \\
\hline 47 Bridseport & Milling Mechine & $\$ 268.30$ & $\$ 1730.00$ & $\$ 1683.00$ & $\$ 2816.00$ & $\$ 112640.00$ & 8945.00 & $\$ 5900.00$ & $\$ 765.00$ & 55474.00 \\
\hline 48 sridseport & Milling Machine & $\$ 268.30$ & $\$ 1730.00$ & $\$ 1603.00$ & $\$ 2816.00$ & $\$ 112640.00$ & 3945.00 & $\$ 2900.00$ & $\$ 745.00$ & 55674.00 \\
\hline 49 Bridseport & Mill ing Mechine & $\$ 268.30$ & $\$ 1730.00$ & $\$ 1683.00$ & $\$ 2816.00$ & $\$ 112640.00$ & $\$ 945.00$ & $\$ 3700.00$ & $\$ 765.00$ & $\$ 5674.00$ \\
\hline 50 Bridseport & Milling Machine & 5917.15 & $\$ 1730.00$ & $\$ 1683.00$ & $\$ 2816.00$ & $\$ 112640.00$ & $\$ 945.00$ & $\$ 3300.00$ & $\$ 745.00$ & 55476.00 \\
\hline 51 Bridseport & Milling Machine & 8406.90 & $\$ 1730.00$ & $\$ 1912.50$ & $\$ 3200.00$ & $\$ 120000.00$ & 5945.00 & $\$ 30200.00$ & $\$ 745.00$ & $\$ 5676.00$ \\
\hline 52 Cinncinati & Milling machine & $\$ 678.10$ & $\$ 1730.00$ & $\$ 2754.00$ & 54608.00 & $\$ 186320.00$ & $\$ 540.00$ & $\$ 20500.00$ & $\$ 1726.00$ & $\$ 12138.00$ \\
\hline 53 Abarbogen Meskim & Drill Press & $\$ 0.00$ & $\$ 233.00$ & $\$ 30.60$ & $\$ 51.20$ & $\$ 2068.00$ & 5100.00 & $\$ 5400.00$ & $\$ 146.00$ & $\$ 1125.00$ \\
\hline $56 \mathrm{MLZ}$ Metall & Drill Press & 5473.20 & 2466.00 & $\$ 364.25$ & $\$ 576.00$ & $\$ 23040.00$ & $\$ 162.00$ & $\$ 3500.00$ & $\$ 329.00$ & $\$ 2699.00$ \\
\hline 55 Walker-Turner & Drill Press & $\$ 2658.80$ & 5466.00 & 5175.95 & 5294.60 & 511776.00 & $\$ 108.00$ & 5990.00 & $\$ 282.00$ & $\$ 2142.00$ \\
\hline
\end{tabular}


Cost Elements for Recycle/neuse Al ternot ives

Page: 3

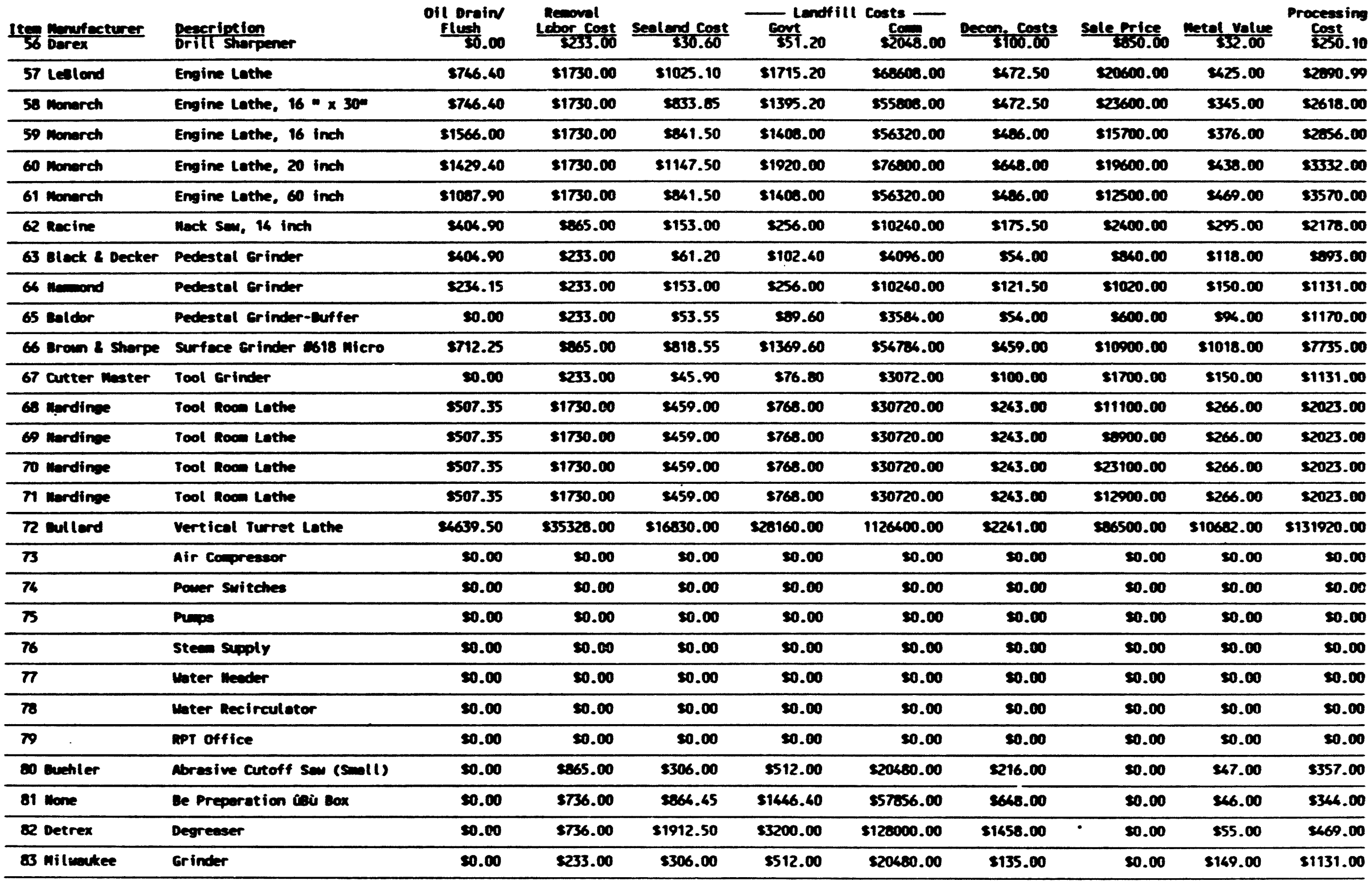




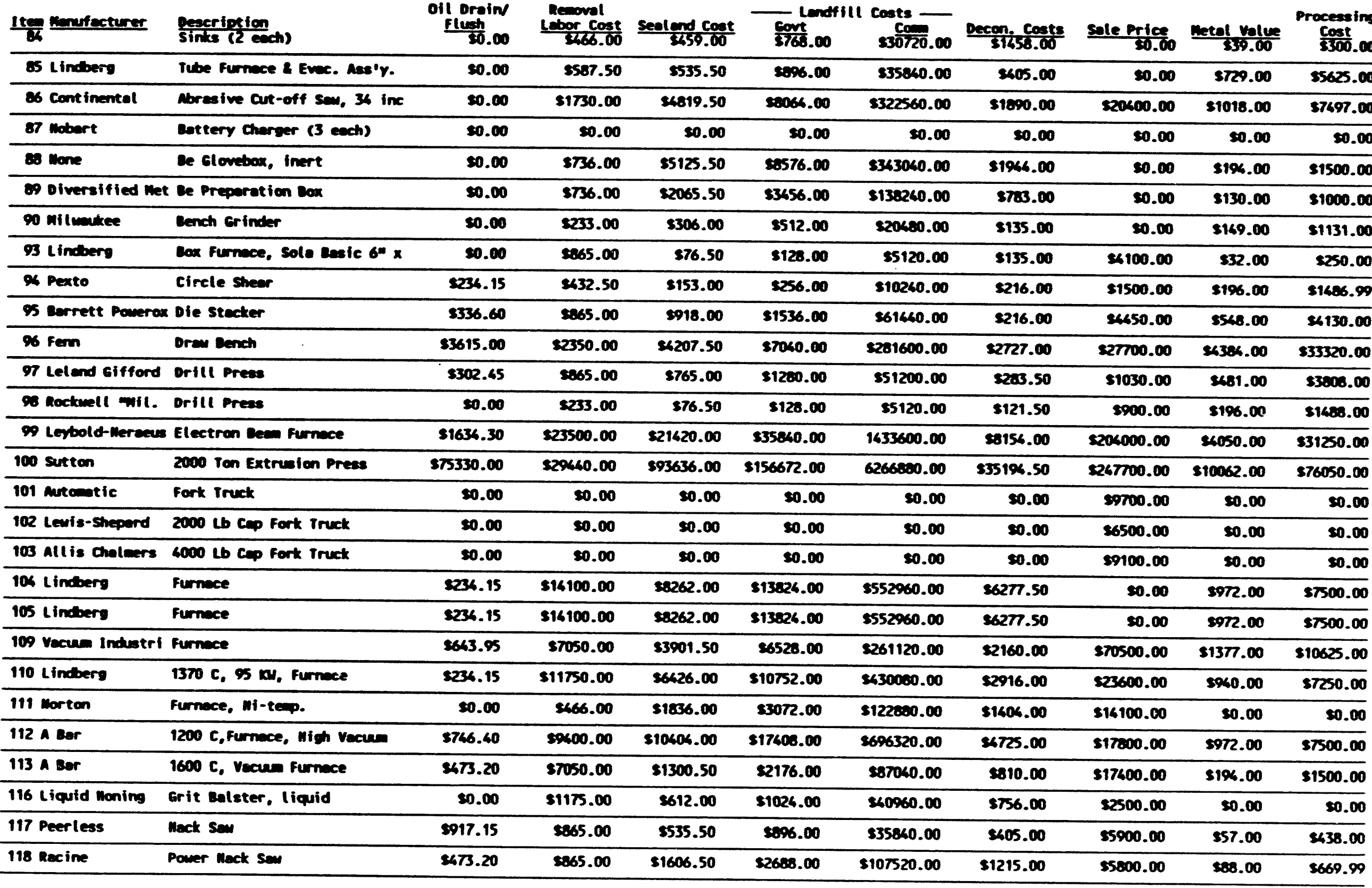


Ite $\frac{\text { nexpecturer }}{\text { Recine }}$

ofl Drain Removel Lendfill costs -

\begin{tabular}{|c|c|c|c|c|c|c|c|c|c|c|}
\hline 120 mitoclewe & Mot Iscostatic Press & $\$ 33871.90$ & $\$ 35328.00$ & $\$ 15300.00$ & $\$ 25600.00$ & 1024000.00 & 510570.50 & $\$ 333400.00$ & $\$ 8500.00$ & 572705.00 \\
\hline 121 Cincinatt I & mydrospin & $\$ 3615.00$ & $\$ 26496.00$ & $\$ 30600.00$ & $\$ 51200.00$ & 2040000.00 & $\$ 10570.50$ & $\$ 118600.00$ & $\$ 21420.00$ & $\$ 1632.00$ \\
\hline 122 Lepel & Indection coil & 90.00 & 5265.00 & $\$ 130.05$ & $\$ 217.60$ & 98704.00 & 5148.50 & 51700.00 & 50.00 & 50.00 \\
\hline 125 CEC & Leak Detector & $\$ 234.15$ & $\$ 265.00$ & $\$ 91.00$ & $\$ 153.60$ & 56146.00 & $\$ 216.00$ & $\$ 5500.00$ & 50.00 & 50.00 \\
\hline 126 Vorien & Lenk Detector & $\$ 234.15$ & $\$ 265.00$ & $\$ 38.25$ & 864.00 & $\$ 2560.00$ & $\$ 216.00$ & $\$ 8600.00$ & 50.00 & 50.00 \\
\hline 127 Lift-n- Loft & 500 lb Cepacity lifter & $\$ 336.60$ & $\$ 233.00$ & $\$ 2210.85$ & $\$ 3699.20$ & 8167968.00 & 599.00 & $\$ 12000.00$ & $\$ 203.00$ & $\$ 1563.00$ \\
\hline 120 eE of Coneda & nerate & $\$ 2070.25$ & $\$ 265.00$ & 84056.50 & 86704.00 & $\$ 271360.00$ & $\$ 1026.00$ & $\$ 107400.00$ & $\$ 1215.00$ & 59375.00 \\
\hline 129 & material storase & 90.00 & 90.00 & 50.00 & 50.00 & 50.00 & $\$ 0.00$ & 90.00 & 90.00 & 50.00 \\
\hline $132 \operatorname{tin}^{2} \cdot 01 \mathrm{sen}$ & Press, 60,000 tbs. & 8609.80 & 5065.00 & $\$ 1205.20$ & $\$ 2150.40$ & $\$ 86016.00$ & 5500.50 & $\$ 13100.00$ & 8405.00 & $\$ 3125.00$ \\
\hline 136 Peck, Stom, \& U & Roller, Fonmer- 20 60. Cop. & $\$ 0.00$ & 2065.00 & 330.60 & 351.20 & $\$ 2048.00$ & $\$ 40.50$ & s870.00 & $\$ 166.00$ & $\$ 1125.00$ \\
\hline 135 stemet & Rolling Mill & 5541.50 & $\$ 6920.00$ & 5887.40 & $\$ 1406.80$ & $\$ 59392.00$ & 869.50 & $\$ 23000.00$ & $\$ 2916.00$ & $\$ 22500.00$ \\
\hline 136 fenn & 7w. 18.4 M.P. Rolling Mill & $\$ 234.15$ & 26920.00 & $\$ 1002.15$ & $\$ 1676.80$ & 867072.00 & 5567.00 & $\$ 1600.00$ & $\$ 2592.00$ & $\$ 20000.00$ \\
\hline 137 United & Rolling Mill & $\$ 3615.00$ & 558000.00 & $\$ 11675.00$ & $\$ 19200.00$ & $\$ 760000.00$ & $\$ 2075.50$ & $\$ 102100.00$ & $\$ 14500.00$ & $\$ 112500.00$ \\
\hline 140 olecro & stweer, *to & $\$ 0.00$ & 2466.00 & $\$ 22.95$ & $\$ 38.40$ & 51536.00 & $\$ 54.00$ & $\$ 1600.00$ & $\$ 49.00$ & $\$ 375.00$ \\
\hline 141 Lodse 8 shipley & Shear. $5 / 0$ inch square $\times 60$ & $\$ 575.65$ & $\$ 1730.00$ & $\$ 3870.90$ & $\$ 6476.80$ & 5259072.00 & 51658.00 & 520500.00 & $\$ 1053.00$ & 58125.00 \\
\hline 142 miller & Spot Welder, Resistence & 90.00 & $\$ 265.00$ & 345.90 & 876.00 & $\$ 3072.00$ & $\$ 54.00$ & $\$ 760.00$ & 50.00 & 50.00 \\
\hline 163 vidur & stecker-Retriever & 2236.15 & $\$ 1730.00$ & $\$ 122.40$ & $\$ 204.80$ & $\$ 8192.00$ & $\$ 216.00$ & 510500.00 & 2405.00 & $\$ 3125.00$ \\
\hline 164 Erie & stean forging waner & 2917.15 & $\$ 35328.00$ & $\$ 32436.00$ & $\$ 54272.00$ & 2170000.00 & 16358.50 & $\$ 96700.00$ & $\$ 38700.00$ & $\$ 292500.00$ \\
\hline 145 Fem & Swoger & 90.00 & $\$ 265.00$ & 5864.45 & 51466.40 & 557056.00 & 2486.00 & $\$ 15700.00$ & $\$ 1394.00$ & $\$ 10530.00$ \\
\hline $166 \mathrm{Fem}$ & suceser, Lerge & 90.00 & 8865.00 & 55163.75 & $\$ 20640.00$ & $\$ 345600.00$ & 51944.00 & 517000.00 & $\$ 2476.00$ & $\$ 18720.00$ \\
\hline 167 & Tool ing Storege & $\$ 0.00$ & 50.00 & 80.00 & 90.00 & 50.00 & 90.00 & 80.00 & 50.00 & 50.00 \\
\hline 148 Erie & Triple action Press, 150 Ton & $\$ 10465.00$ & 517664.00 & 511475.00 & $\$ 19200.00$ & $\$ 760000.00$ & $\$ 1107.00$ & $\$ 112700.00$ & $\$ 12040.00$ & $\$ 81900.00$ \\
\hline 149 Brew & Vecuen Fumece & 52305.60 & 51730.00 & $\$ 5806.35$ & 59715.20 & 8383608.00 & $\$ 3510.00$ & $\$ 1500.00$ & $\$ 196.00$ & $\$ 1500.00$ \\
\hline 150 Ajax Morthrup & Vecure Induction Furnece & $\$ 1258.65$ & $\$ 9400.00$ & $\$ 2195.55$ & $\$ 3673.60$ & $\$ 166946.00$ & 84655.00 & $\$ 17700.00$ & $\$ 4860.00$ & $\$ 37500.00$ \\
\hline 151 & Woste Box Storege & 90.00 & 90.00 & 90.00 & 50.00 & 50.00 & 50.00 & 50.00 & 50.00 & 50.00 \\
\hline 152 & Stepoff Pad & 90.00 & 50.00 & 90.00 & 90.00 & 50.00 & 90.00 & 50.00 & 50.00 & 50.00 \\
\hline 153 Coul ter Electro & coulter counter & 5234.15 & $\$ 466.00$ & $\$ 165.35$ & $\$ 263.20$ & 59728.00 & $\$ 200.00$ & 50.00 & 50.00 & 50.00 \\
\hline
\end{tabular}


Cost Elements for Recycle/Reuse Alternat ives

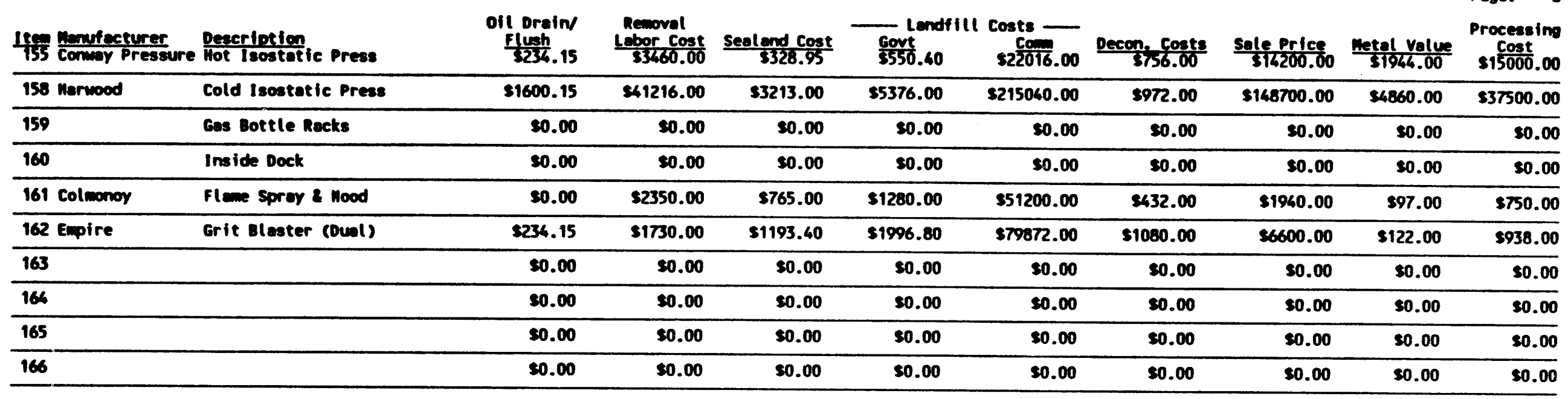




\section{STAGING \& DECONTAMINATION AREA COST}

The cost estimate is based on the description below, and assumes construction by a fixed-price contractor within Building 865. Pricing and labor costs (with the exception of the $\mathrm{CO}_{2}$ Blaster and its auxiliaries) are derived from R. S. Means' "Building Construction Cost Data," 1989 edition, escalated to current (1993) dollars using DOE escalators. Pricing for the $\mathrm{CO}_{2}$ Blaster was taken from a manufacturer's quotation to EG\&G in August 1992.

The estimate covers the installation of a dry $\mathrm{CO}_{2}$ decon system, that can be converted to a conventional wet system by changing the dry filters in the booth to a water wall and adding a much larger RCRA Treatment System. If future conditions warrant this conversion, the overall cost differential should be very small.

\section{BUILDING 865 D\&D NEEDS}

\section{DECON STAGING AREA}

Approximately $31 \mathrm{ft} \times 62 \mathrm{ft}$ (two bays) adjacent to Decon Staging.

Floor to be 10-gal. stainless steel with 4-in. curbing four sides, and sloped approximately 2 in. to a collection point for easy cleanup.

A 4-in. (curb high) ramp will be at the entry and exit points to the Staging Area.

No walls required, roping-off or fencing optional.

Parts racks to be installed with shelves approximately $4 \mathrm{ft} \times 4 \mathrm{ft} \times 6$ in. off floor and $3 \mathrm{ft}$ off floor. $28 \mathrm{ft}$ of racks against the wall, built of 10 -gal. steel.

\section{DECON STATION ROOMD}

Approximately $30 \mathrm{ft} \times 30 \mathrm{ft}$ (one bay)

Room to be walled four sides with metal paneling Epoxy coated.

Floor to be 10-gal. stainless steel with 4-in. curbing four sides.

The floor shall slope approximately 2 in. toward a floor collection point for easy cleanup.

The one Main Entry/Exit door will be $10 \mathrm{ft}$ wide $\times 10 \mathrm{ft}$ high vertically operated, normally closed, entry from within Building 865 . Two $10 \mathrm{ft} \times 10 \mathrm{ft}$ doors optional. 
A 4-in. (curb high) ramp will be at the Main Entry/Exit door.

Two pedestrian doors will be installed; one next to the main door and the other in the adjacent wall.

The ceiling shall be $12 \mathrm{ft}$ high, of metal construction, and epoxy coated. Adequate lighting shall be installed in the ceiling. Industrial standard fire protection sprinkler system will be required.

Exhaust air outlets shall be in or near the room ceiling.

The exhaust air system shall be provided with a blower capable of one air change per two minutes for the Decon Station Room.

The system shall be equipped with a Demister and Air Heater for intercepting any moisture-laden exhaust air.

The exhaust system shall be of stainless steel ductwork equipped with MEPA and HEPA filter banks in series to remove decontamination from the exhaust air.

Differential Pressure Indicators/Alarms shall be installed on each side of the MEPA/HEPA filter banks to alert to need of filter change-out or indicate filter rupture.

A structural steel equipment platform shall be erected above the Decon Room to support the MEPA/HEPA filter banks, exhaust blower, and other exhaust-related equipment. The platform shall be designed to accommodate filter change-out and equipment maintenance. The platform shall also support the exhaust stack, which would protrude through or above the roof of Building 865 .

The stainless steel stack will accommodate the exhaust from the Decon Room. In the stack, an Isokinetic Stack Flow Indicator and Alarm will be installed to alert to malfunctions of the system, blower, or filter bank. A Radioactive Particulate Monitor/ Alarm will be installed in the stack or stack entry to alert to excessive radioactive conditions in the exhaust stack emissions. Alarms from the above monitors and indicators will be in the Staging Area and Decon Room to alert the operators.

Make-up air to the Decon Room will come from the Building (856) proper, via vents in the Decon Room walls.

Flexible exhaust drop ducts (elephant trunks) from the overhead exhaust system will be available at two locations used for localized exhaust.

The Decon Room will house the necessary equipment for the decontaminated operations, as listed below. 
$\mathrm{CO}_{2}$ Cleaning Equipment of either or both an Alpheus Model 250 by Environmental Alternatives, Inc., or a Cold Jet Model RDS $1000 \mathrm{~J}$ by Environmental Control Division, Inc., and including the $\mathrm{CO}_{2}$ supply equipment.

\section{ADDITIONAL NEEDS IF HIGH PRESSURE WATER JET CLEANING PROCESSES} ARE CONTEMPLATED (Not recommended for Building 865 equipment decontamination)

1) The floor collection point in the Decon Room would be a sump with sump pump to handle up to $1,600 \mathrm{gal}$. of contaminated floor drainage per 8-hour shịft.

2) The sump pump would deliver the contaminated water through two filter units in series. The first filter unit would be a three-bag filter and the second a single-bag filter.

3) The contaminated water from the filter units would NOT be recyclable and will require further decontamination processing. This water would contain nonfilterable contaminants suspended and dissolved. Attempting to recycle-use would further contaminate any equipment.

4) A tank of approximately 500-gal. capacity would be required to supply the high pressure water jet systems. A water heater to heat the water from this tank would be required with water heating capability between $185^{\circ} \mathrm{F}$ to $200^{\circ} \mathrm{F}$. Make-up water to the tank would be from the RFP system and controlled by a lov/-level control switch.

5) The Decon Room would house the following additional equipment:

a) A 35,000-psi Ultra High Pressure Water Jet Cleaning System, Model $103 X$ Series JetPac from ADMAC, Inc., $4.2 \mathrm{gpm}, 150 \mathrm{hp}$, with toolsets, lances, nozzles, etc., or equal.

b) A 2,500-psi High Pressure Water Jet Cleaning system, $4.5 \mathrm{gpm}$ output, $71 / 2 \mathrm{hp}$ with necessary auxiliaries.

The 35,000-psi pump unit will require barricade shielding about $5 \mathrm{ft}$ height of $1 / 2$-in. Lexan polycarbonate. In the event of a pump rupture, the resulting missiles are extremely hazardous. (No standards or codes exist for the design of UHP pumps.)

Several portable shields of $1 / 2$-in. Lexan will be necessary for high pressure jet protection.

The Decon Room would require water hose-down crpability. 


\begin{tabular}{|c|c|c|c|c|c|c|c|c|c|}
\hline \multicolumn{10}{|c|}{ Staging \& Decontamination Area Cost Estimate } \\
\hline $\begin{array}{l}\text { Item } \\
\text { No. }\end{array}$ & $\begin{array}{l}\text { Material and } \\
\text { Description }\end{array}$ & Quantity & Unit & $\begin{array}{l}\text { Unit } \\
\text { Cost }\end{array}$ & $\begin{array}{c}\text { Material } \\
\text { Total }\end{array}$ & Unit & Rate & Crt. & $\begin{array}{l}\text { Labor } \\
\text { Total }\end{array}$ \\
\hline 1 & $\begin{array}{l}\text { Chip out concrete floor } \\
\text { down to top of steel } 6^{\prime \prime} W \times \\
2^{\prime \prime} \text { deep for curb }\end{array}$ & 93 & SF & & & 0.10 & 22.71 & B-9 & 211.20 \\
\hline 2 & $\begin{array}{l}\text { Curb reinforced concrete } \\
\text { including reinforcing, } \\
\text { anchors in floor slab } \\
12^{\circ} \mathrm{OC} \text {, forms and finishing }\end{array}$ & 186 & $\mathbf{L F}$ & 3.60 & 669.00 & 0.180 & 23.40 & C-15 & 783.43 \\
\hline 3 & $\begin{array}{l}\text { Floor topping } 2^{*} \text { Nom. } \\
\text { slope } 12 \times 12 \times 12^{\prime} \text { sump at } \\
\text { corner of each bay. (2- } \\
\text { bays) }\end{array}$ & 1922 & SF & .60 & $1,153.00$ & .064 & 24.83 & C-10 & $3,054.00$ \\
\hline 4 & $\begin{array}{l}\text { Sump Pump 1/2 HP } \\
\text { stainless. Man. control }\end{array}$ & 2 & Ea & 260 & 520 & 1.6 & 24.77 & Q-1 & 80.00 \\
\hline 5 & $\begin{array}{l}\text { Extend building RCRA } \\
\text { waste drain to sump pumps. } \\
\text { 1/2"SS line W/ check valve } \\
\text { at the pumps }\end{array}$ & 1 & Lot & 600 & 600 & 40 & 24.77 & Q-1 & 990.00 \\
\hline 6 & $\begin{array}{l}\text { 16-gal. stainless steel floor } \\
\text { overlay, ramset } 12^{n} \text { OC } \\
\text { to F1 slab, back welded \& } \\
\text { ground smooth. } 4 \text { × } 8 \\
\text { sheets welded at seams }\end{array}$ & 1922 & SF & 5.85 & $11,244.00$ & 0.145 & 23.84 & G-3 & $8,251.98$ \\
\hline
\end{tabular}




\begin{tabular}{|c|c|c|c|c|c|c|c|c|c|}
\hline \multicolumn{10}{|c|}{ Staging \& Decontamination Area Cost Estimate } \\
\hline $\begin{array}{l}\text { Item } \\
\text { No. }\end{array}$ & $\begin{array}{c}\text { Material and } \\
\text { Description } \\
\end{array}$ & Quantity & Unit & $\begin{array}{l}\text { Unit } \\
\text { Cost } \\
\end{array}$ & $\begin{array}{c}\text { Material } \\
\text { Total } \\
\end{array}$ & Unit & Rate & Cnt. & $\begin{array}{l}\text { Labor } \\
\text { Total } \\
\end{array}$ \\
\hline 7 & $\begin{array}{l}\text { Paint spray booth wet/dry } \\
\text { w/dry MEPA/HEPA filters. } \\
16 \times 16 \times 16 \text { epoxy coated } \\
\text { metal panels w/service \& } \\
\text { personnel doors. } 3000 \mathrm{cfm} \\
\text { exhauster inc. controls }\end{array}$ & 1 & Lot & & $19,800.00$ & & & & $5,000.00$ \\
\hline 8 & $\begin{array}{l}\text { Exhaust stack \& monitor } \\
12^{\prime \prime} \text { dia SS with isokinetic } \\
\text { monitor and alarm }\end{array}$ & 1 & Lot & & $20,000.00$ & & & & $4,000.00$ \\
\hline 9 & $\begin{array}{l}\text { Extend existing house vac } \\
\text { sys into decon booth } \\
\end{array}$ & 1 & Lot & & $1,200.00$ & & & & 800.00 \\
\hline 10 & $\begin{array}{l}\mathrm{CO}_{2} \text { Blaster Alpheus Model } \\
250 \text { w/gun and hose }\end{array}$ & 1 & Ea & & $107,000.00$ & & & & \\
\hline 11 & Air Compressor & 1 & Ea & & $81,000.00$ & & & & \\
\hline 12 & Air Dryer & 1 & Ea & & $21,000.00$ & & & & \\
\hline 13 & $\mathrm{CO}_{2}$ Storage Tank & 1 & Ea & & $46,000.00$ & & & & \\
\hline 14 & $\begin{array}{l}\text { Increase building supply air } \\
\text { capacity to offset decon } \\
\text { exhaust. Roof mounted } \\
\text { package unit }\end{array}$ & 1 & Lot & & $4,800.00$ & 16 & 27.30 & Q-9 & 437.00 \\
\hline 15 & $\begin{array}{l}\text { Extend } 480-\mathrm{V} \text { building } \\
\text { power to new equipment }\end{array}$ & 1 & Lot & & $1,200.00$ & 40 & 27.30 & $1-E$ & $1,092.00$ \\
\hline
\end{tabular}




\begin{tabular}{|c|c|c|c|c|c|c|c|c|c|}
\hline \multicolumn{10}{|c|}{ Staging \& Decontamination Area Cost Estimate } \\
\hline $\begin{array}{l}\text { Item } \\
\text { No. }\end{array}$ & $\begin{array}{l}\text { Material and } \\
\text { Description }\end{array}$ & Quantity & Unit & $\begin{array}{l}\text { Unit } \\
\text { Cost }\end{array}$ & $\begin{array}{c}\text { Material } \\
\text { Total }\end{array}$ & Unit & Rate & Cn. & $\begin{array}{l}\text { Labor } \\
\text { Total }\end{array}$ \\
\hline 16 & $\begin{array}{l}\text { Extend } 125-\mathrm{V} \text { building } \\
\text { power to booth lighting and } \\
\text { sump pumps }\end{array}$ & 1 & Lot & & 600.00 & 20 & 27.30 & 1-E & 546.00 \\
\hline & $\begin{array}{l}\text { Subtotal } \\
\text { OH\&P } 21 \% \mathrm{M} 50 \% \mathrm{~L} \\
\text { Clothing Change } 20 \% \mathrm{~L} \\
\text { Security Escort } 3 \mathrm{men} / 3 \\
\text { mos. } \\
\text { Contingency } 30 \% \mathrm{M} \mathrm{\&} \mathrm{L} \\
\text { Total Cost }\end{array}$ & & & & $\begin{array}{r}316,786.00 \\
66,525.00 \\
77,850.00 \\
138,348.00 \\
599,509.00\end{array}$ & & & & $\begin{array}{r}25,145.00 \\
12,573.00 \\
5,029.00 \\
\\
12,824.00 \\
55.571 .00 \\
655,000.00 \\
\end{array}$ \\
\hline
\end{tabular}




\section{D.1 EQUIPMENT DECONTAMINATION AND CARBON DIOXIDE CLEANING}

The EG\&G White Paper describing the $\mathrm{CO}_{2}$ decontaminating process expresses costs in terms of pounds of metal cleaned. This was done to illustrate the advantage of $\mathrm{CO}_{2}$ decontamination vs. shipping and interment costs at the Nevada Test Site. The demonstration set-up exhibited an operating cost of about $300 \$ / \mathrm{hr}$. and an optimum production rate of $130 \mathrm{lbs} / \mathrm{hr}$. This production rate is based on the cleaning of plate, structural shapes and ductwork all with few if any surface irregularities. We feel that a production rate of $100 \mathrm{lbs} / \mathrm{hr}$. would be more realistic for cleaning machines and process equipment with the myriad of irregular surfaces. The correlation between area cleaned and pounds processed is derived below.

$$
1 / 8^{\prime \prime} \text { plate }\left(20^{\prime \prime} \times 48^{\prime \prime}\right)=30 \mathrm{lbs}
$$

$$
\text { Thus } \frac{2[20 \times 48]}{144 \text { in. }^{2} \mid f^{2} \times 30 l b}=0.44 \text { SF } / l b
$$

$$
\text { Thus Clean Cost }=\frac{300 \$ / h r(1.5) *}{.44 S F / l b \times 100 \mathrm{lb} / \mathrm{hr}}=10.23 \$ / S F-\text { With Monitoring 12.00\$/SF }
$$

*An empirical factor was added to account for additional time needed to remove the paint from equipment.

The surfaces cleaned by the $\mathrm{CO}_{2}$ process will have to be immediately protected against rust and so the cost will include the application of a suitable primer and two coats of enamel @ $1.50 \$ / S F$.

$$
\text { Total Decon Cost }=13.50 \$ / S F
$$

Decontamination for scrap metal was developed by adjusting the decon cost developed above (less the cost of painting) times a factor of 2 which accounts for the increased surface area due to additional equipment disassemble. The decontamination cost for scrap metal becomes $\$ 24 / \mathrm{ft}^{2}$.

The Capitol Cost for the $\mathrm{CO}_{2}$ facility listed in Appendix $\mathrm{C}$ omits the blaster booth with HEPA filtered exhaust and a stack monitoring system. Adding these features at $\$ 60,000$ and $\$ 20,000$ 
respectively and estimating the cost for installation, gives a facility cost of 655,000 in Building 865. Assuming a fifteen-year write-off, the duration of this project would incur a cost of about $\$ 65,000$.

\section{D.2 METHODOLOGY FOR ESTIMATING FAIR MARKET VALUE}

The most straight forward method of determining the probable sale value of this equipment is: (1) determine the actual purchase date; (2) escalate to the present date using DOE generated escalators (replacement value); and (3) reduce the replacement value by an appropriate factor to arrive at a sale value.

Purchase Date: $\quad$ Derived from the RFP Property number and corrected by dates found on manufacturers data in the files. (Numerous items were transferred to the RFP from other agencies and entered into property records at the transfer date, not the manufacture date-thus implying much newer equipment than it actually is.)

Replacement Value: Original purchase price times the appropriate DOE-ORO Escalator.

Sale Value:

Replacement Value times Used Equipment Discount. These discounts usually range from $25 \%$ on high demand equipment to as much as $75 \%$ on little used items. We have used a $40 \%$ discount primarily because this list of equipment has been screened and doubtful equipment eliminated. Thus, this listing includes only equipment that would be rated "good" or better commercially.

Cost of Sale: $\quad$ Commercial Dealers will charge approximately $15 \%$ of the sale value for brokerage, advertising, handling, and warehousing.

This scenario assumes that the equipment can be decontaminated to a level to permit public sale without doing irreparable harm to the equipment itself. The best overall return would be achieved if the equipment could be transferred to other DOE facilities where the relatively low level of contamination present would not be objectional.

\section{D.3 EQUIPMENT REMOVAL ASSUMPTIONS \& ESTIMATED REMOVAL COSTS}

1. The equipment will be disconnected from all services and removed from the Building by an independent contractor specializing in handling machinery and process equipment. (The Operating Contractor -would be unduly influenced by procedures, craft jurisdictions and customs that would adversely affect costs.) 
2. Machines and process equipment will be dismantled only to the extent necessary for their removal as dictated by weight and dimensional restrictions. Any further tear-down for decontamination, volume reduction or smelting (material segregation or size limitations) will be addressed and their costs estimated for the specific scenarios.

3. All equipment is assumed to be transported to an onsite area (possibly within the building itself) for further processing, such as decontamination, refurbishing, packaging for interment, etc.

4. Several of the larger machines contain significant amounts of hydraulic oil which are assumed to be PCB based. Since the oil would have to be drained in order to remove the equipment, the cost of drumming, shipping and incineration (via commercial incinerator) will be included in the removal estimate.

5. Removal estimates are based on the use of an appropriate composite crew using BLS listed labor rates for the Denver Company area. Base estimates will be expressed in crew manhours times crew rate to give Subcontractor direct labor. Material will be limited to rigging, blocking, and equipment rental. Subcontractor (OH\&P) is added @ $10 \% \mathrm{M}-15 \% \mathrm{~L} \&$ General Contractor (OH\&P) added @ $15 \% \mathrm{M} \& 35 \% \mathrm{~L}$.

6. The required "Fixed Price Personnel Training" is a one time cost for the Contractor and is assumed to be covered by the slightly higher than normal OH\&P multipliers. Monitoring, both HP \& HH, is assumed to be an Operating Contractor function and is not included in equipment removal costs.

7. Since no schedule for the equipment removal has been established, the estimates are presented in 2 nd quarter $93 \$$.

8. Since the estimates are conceptual in nature, a 30\% Contingency is applied overall. 


\section{COMPOSITE CREWS}

\begin{tabular}{|c|c|c|c|c|c|}
\hline \multirow[t]{2}{*}{ Crew A } & \multicolumn{5}{|c|}{ Primarily Metallurgical Laboratory Equipment, Plug-in desk Lop mounted (Items 1 thru 32) } \\
\hline & & $\begin{array}{l}\text { Labor } \\
\text { Rate }\end{array}$ & $\begin{array}{l}\text { Total } \\
\text { Labor } \\
\text { Cost }\end{array}$ & Material & Total Cost $/ \mathrm{Hr}$ \\
\hline & 1 - Non-Working Foremen & 19.63 & $\$ 19.63$ & & \\
\hline & 4- Building Laborers & 19.13 & 76.52 & & \\
\hline & Hand Truck Rental & & & $17.5 / \mathrm{hr}$ & \\
\hline & Sub-Total & & 96.15 & 17.50 & \\
\hline & OH\&P (SUB \& Gen.) 50\% L 21\% M & & 46.22 & 3.85 & \\
\hline & Clothing Change 20\% L & & 19.23 & & \\
\hline & Security Escort $1 \mathrm{mr} / \mathrm{hr} @ \$ \$ 50 / \mathrm{hr}$ & & & 50.00 & \\
\hline & TOTAL COST & & 161.60 & 71.35 & $\begin{array}{l}232.95 \\
\text { (use 233) }\end{array}$ \\
\hline Crew B & \multicolumn{5}{|c|}{$\begin{array}{l}\text { Self-contained machines requiring little or no disassembly for removal. Small milling machines, engine } \\
\text { lathes, band saws, drill presses, pedestal grinders, and shoet metal machinery. }\end{array}$} \\
\hline & 1 - Non-Working Foremen & 23.03 & $\$ 28.03$ & & \\
\hline & 2 - Electricians & 27.53 & 55.06 & & \\
\hline & 2-Millwrights & 25.14 & 50.28 & & \\
\hline & $2-$ Pipefitters & 27.87 & 55.74 & & \\
\hline & 4- Ironworkers (Riggers) & 26.40 & 105.58 & & \\
\hline & 1 - Equipment Operator (Forklift) & 24.57 & 24.57 & & \\
\hline & Fork Lift Rental & & & 21.96 & \\
\hline & $\begin{array}{l}\text { Rigging Rental (Jacks, Como-alongs, } \\
\text { etc. }\end{array}$ & & & 37.50 & \\
\hline & Sub-Total & & 319.26 & 59.46 & \\
\hline & OH\&P 50\% L 21\% M & & 159.63 & 12.44 & \\
\hline & Clothing Change $20 \% \mathrm{~L}$ & & 63.85 & & \\
\hline & Security Escort $5 \mathrm{mh} / \mathrm{hr} @ 50 / \mathrm{hr}$ & & & 250.00 & \\
\hline & TOTAL COST & & 542.74 & 321.90 & $\begin{array}{l}864.64 \\
\text { (use 865) }\end{array}$ \\
\hline
\end{tabular}




\begin{tabular}{|c|c|c|c|c|c|}
\hline \multirow[t]{2}{*}{ Crew C } & \multicolumn{5}{|c|}{$\begin{array}{l}\text { Equipment composed of systems containing auxiliary equipment that must be dismantled and handled as } \\
\text { separate entities. Vacuum Furnaces, Vacuum Arc Melter Atmosphere Furnaces and Electron Beam } \\
\text { Furnace. }\end{array}$} \\
\hline & 1 - Non-Working Foreman & 28.03 & $\$ 28.03$ & & \\
\hline & 2 - Electricians & 27.53 & 55.06 & & \\
\hline & 2 - Millwrights & 25.14 & 50.28 & & \\
\hline & 2 - Pipefitters & 27.87 & 55.74 & & \\
\hline & 4- Ironworkers (Riggers) & 26.40 & 105.58 & & \\
\hline & 2 - Sheetmetal Workers & 27.30 & 54.60 & & \\
\hline & 2 - Equipment Operators & 24.57 & 49.14 & & \\
\hline & Fork Lift Rental & & & 21.96 & \\
\hline & Mobile Crape Rental 25T & & & 77.21 & \\
\hline & Rigging Rental & & & 64.50 & \\
\hline & Sub-Total & & 398.43 & 163.67 & \\
\hline & OHSP 50\% L 21\% M & & 199.21 & 34.37 & \\
\hline & Clothing Change $20 \% \mathrm{~L}$ & & 79.69 & & \\
\hline & Security Escort $6 \mathrm{mh} / \mathrm{hr} @ 50 / \mathrm{hr}$ & & & 300.00 & \\
\hline & TOTAL COST & & 677.33 & 498.04 & $\begin{array}{l}1,175.37 \\
\text { (use } 1,175)\end{array}$ \\
\hline \multirow[t]{11}{*}{ Crew D } & \multicolumn{5}{|c|}{$\begin{array}{l}\text { Equipment as in Crew C with an added weight or size requiring significant disassembly for removal. } \\
\text { Isostatic Presses, Extrusion Press, 64" VTL and Forging Press. }\end{array}$} \\
\hline & 1 - Non-Working Foremen & 28.03 & 28.03 & & \\
\hline & 2 - Electricians & 27.53 & 55.06 & & \\
\hline & 3 - Millwrights & 25.14 & 75.42 & & \\
\hline & 2-Pipefitters & 27.87 & 55.74 & & \\
\hline & 6 - Ironworkers (Riggers) & 26.40 & 158.40 & & \\
\hline & 2- Sheetmetal Workers & 27.30 & 54.60 & & \\
\hline & 2 - Equipment Operators & 24.57 & 49.14 & & \\
\hline & Fork Lift Rental & & & 21.96 & \\
\hline & Mobil Crane Rental 25T & & & 77.21 & \\
\hline & Rigging Rental & & & 64.50 & \\
\hline
\end{tabular}




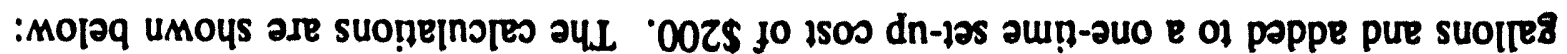

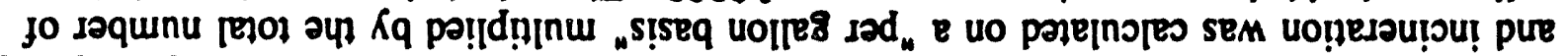

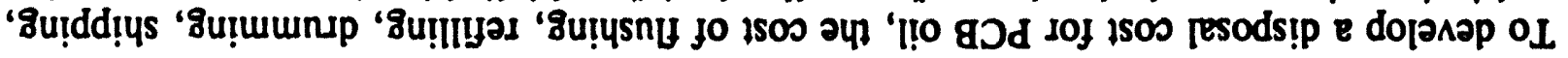

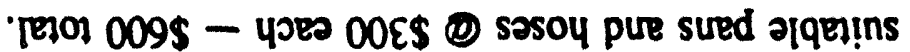

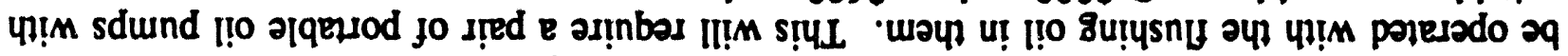

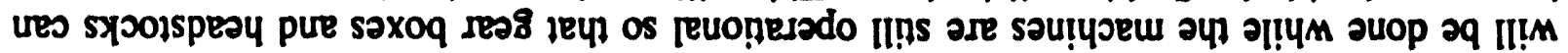

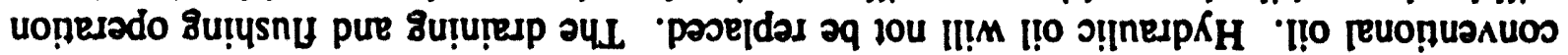

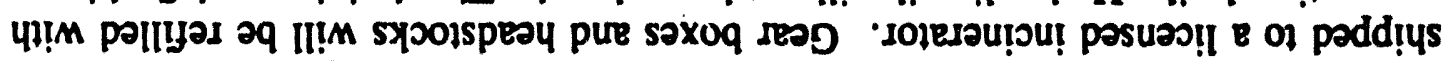
pure poumunsp әq Il!̣ [!o 8u!

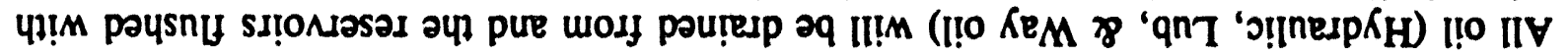

TVSOASIa TIO gOd $\bullet^{\circ}$ a

\begin{tabular}{|c|c|c|c|c|c|}
\hline $00 .<96$ & & & & 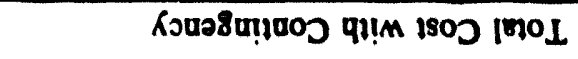 & \\
\hline \multirow[t]{10}{*}{$\begin{array}{r}\text { (6SE OSn) } \\
90^{\circ} 6 S E\end{array}$} & $I b^{\prime} S L$ & $59 . \varepsilon 8 Z$ & & ISOJ TVIOL & \\
\hline & 00.05 & & & OS (1) squsu I Loosg Ku!nnoss & \\
\hline & & LE'EE & & 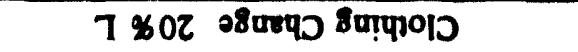 & \\
\hline & $16 \cdot 6$ & Et'E8 & & W \&IZ I \%OS dTHO & \\
\hline & $00 \cdot 12$ & 58.991 & & Inor-qns & \\
\hline & $00 \cdot 12$ & & & 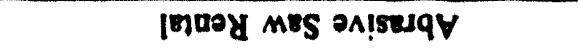 & \\
\hline & & $92 \cdot 8 \varepsilon$ & El'6l & sدองоq 1 8u!p!!ng - Z & \\
\hline & & $95^{\circ} \infty 1$ & $D 1 \Omega$ & s)प8!umII!W - & \\
\hline & & E0.825 & ⿷0'82 & uewosog $801 \% 10 M-00 N-I$ & \\
\hline & & & & uo!jonpas ox!! 78 K!quessus! & 1 mad \\
\hline \multirow[t]{5}{*}{ 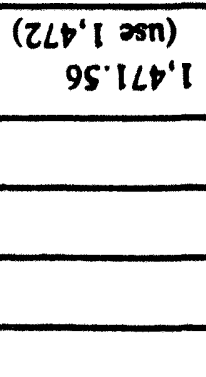 } & 50.860 & ZS'ELG & & LSOS TVLOL & \\
\hline & $00^{\circ} 00 \mathrm{E}$ & & & OS (1) Iq/4س 9 Loseg Kipnoes & \\
\hline & & $\angle 2 \cdot S 6$ & & 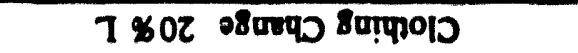 & \\
\hline & $\angle E^{\prime} b E$ & $61 \cdot 8 E 2$ & & W\%IZ7\%OS d\%HO & \\
\hline & L9'E9I & $6 E^{\prime} 9 L V$ & & [nol-qns & \\
\hline
\end{tabular}

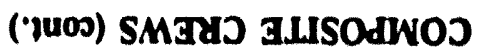


Total PCB Disposal Cost $=$ Setup Cost $200.00+$

【[5.00/8al $\times 2$ Flushing Oil + Refill $7.50 / 8 a l$

+ Drum Cast $\frac{228}{55}+\frac{\text { Shipping Cost* }}{55}+$ Incineration Cost 11/gal]* gal]

$=200+[[10+7.5+4.15+1.50+11] * 8 a \rrbracket]$

$P C B$ Dispasal Cast $=200+[34.15 / 8 a l * 8 a l]$

Incinerator cost for TSCA/LLW waste are \$92/gal based on costs from the K-25 TWCA Incinerator. The following equation represents the cost for removal and disposal of TSCA/LLW wastes. Replacing \$92/gal incineration cost with $\$ 11 / \mathrm{gal}$ in the above equation results in a per-gallon cost of $\$ 115.15$. Therefore,

$$
\text { Total PCB/LLW Disposal Cost }=200+(115.15 / 8 a l * g a l)
$$

*Ship to Little Rock, Arkansas

\section{D.5 EQUIPMENT BURIAL}

Equipment items in the inventory designated as scrap (codes 6 and above) will be disposed of by burial and the entire inventory so disposed of in one scenario. Packaging for burial is assumed to be Sea-Land (SL) containers with a purchase price of \$5000. Each SL container has a $8 \times 8 \times 20=1280 \mathrm{CF}$ envelope and a weight limit of $40,000 \mathrm{lbs}$. Transportation to NTS is based on full $40 \mathrm{~K}$ loads from Denver or 1250 per container. Interment cost is assumed to be either $\$ 10 / C F$ (the current NTS rate) or $\$ 400 / C F$, the probable future rate. Loading and Blocking of an average SL is estimated to be $\$ 500$.

\footnotetext{
Container and Transportation Cast $=\$ \$ 5,000$ ( $\$ L$ container cast) $+\$ 2,150$ (transportation)$$
+500=\$ 7,650 / S L
$$$$
\text { Dispasal Cast (Commercial) }=1,280 A^{3} * \$ 10 / f^{3}=\$ 12,900 / S L
$$$$
\text { Dispasal Cast (Government) }=1,280 \mathrm{~A}^{3} * 400 / \mathrm{f}^{3}=\$ 512,000 / S L
$$ 


\section{D.6 SMELTING OPTION}

This option will require almost complete disassembly of the equipment and its auxiliaries for segregation of metals and reduction of component size to accommodate the charging opening in the smelter. For estimating purposes, the smelter is assumed to be an arc furnace with a $3000 \mathrm{lb}$. ingot mold and a 30-inch diameter charging opening. Segregation will be limited to cast iron and higher melting temperature alloys. The nonferrous metal content of the equipment is considered negligible. Disassembly and size reduction will be done by a crew of Millwrights. The estimates assume disassembly will involve the use of powered mechanical tools and size reduction will use portable abrasive saws with some sledge hammer work on larger castings. Costs are in terms of crew hours and dollars.

Metal input is taken from manufacturers published weights with an appropriate ratio for cast iron and steel applied. Melting costs are taken as $1.15 / \mathrm{lb} \& 1.25 / \mathrm{lb}$, respectively. Slag is assumed to be $10 \%$ of metal input and is priced as burial waste @ $\$ 16 / \mathrm{ft}^{3}$ (government) or $\$ 640 / \mathrm{ft}^{3}$ (commercial). The bulk metal value was obtained from Metal Working News (June $10,1993)$. The resale price of cast iron was $17 \mathrm{c} / \mathrm{lb}$ and stainless steel was $18 \mathrm{c} / \mathrm{lb}$.

\section{D.7 MANAGEMENT AND REGULATORY COMPLIANCE COST}

To estimate the cost for management of the program, management of projects (including subcontractors), and resources to conduct compliance activities, the shaft necessary for each option are shown in the table below. Rates reflect fully burdened costs to the government.

\begin{tabular}{|c|c|c|c|c|c|c|}
\hline \multicolumn{7}{|c|}{ Management Cost } \\
\hline \multicolumn{7}{|c|}{ Overhead \& GA factor $\sim 3.5$} \\
\hline Alternative & $\begin{array}{l}\text { Managers } \\
(\$ 105 / \mathrm{hr})\end{array}$ & $\begin{array}{l}\text { Project } \\
\text { Managers } \\
(\$ 78 / \mathbf{h r}) \\
\end{array}$ & $\begin{array}{l}\text { Regulatory } \\
\text { Compliance } \\
(\$ 60 / \mathrm{hr})\end{array}$ & $\begin{array}{l}\text { Administrative } \\
\text { Support } \\
(\$ 35 / \mathrm{hr})\end{array}$ & $\begin{array}{c}\text { Duration } \\
\text { (yr) }\end{array}$ & $\begin{array}{c}\text { Total Cost } \\
\text { S }\end{array}$ \\
\hline Land Disposal & 1 & 2 & 6 & 2 & 2 & $2,764,000$ \\
\hline Recycle & 1 & 1 & 2 & 1 & 2 & $1,352,000$ \\
\hline $\begin{array}{l}\text { Sale to the } \\
\text { Public }\end{array}$ & 1 & 2 & 8 & 3 & 2 & $3,384,000$ \\
\hline $\begin{array}{l}\text { Transfer to } \\
\text { Government }\end{array}$ & 1 & 1 & 2 & 1 & 2 & $1,352,000$ \\
\hline
\end{tabular}

\section{D.8 COST FOR SURVEYING}

Some of the options will require additional surveying and documentation to verify meeting or free-release criteria. These options include the recycling, sale to the public, and transfer of 
clean equipment within the goven:ment sector. The staff required to accomplish this includes two full-time EEG employees for two years. A fully burdened rate of $\$ 60 / \mathrm{hr}$. was used.

$2 H P \times 40 h r / w k \times 50 w k / y r \times 2$ yr $\times \$ 60 / h r=\$ 480,000$

\section{D.9 PACKAGING FOR REUSE OR RESALE}

After decontamination and prior to painting, equipment to be transferred or to be offered for sale, will be provided with pallets or custom-built skids to facilitate handling and at the same time preserve basic alignments of machine tools. Pallets will be standard $4 \times 4$ forklift units with a $2,000 \mathrm{lb}(125 \mathrm{lb} / \mathrm{SF})$ load rating. After painting, individual items will be strapped to the pallet to provide stability. The pallet plus strapping is estimated to cost $50 \$ /$ unit. Skids will range from 50 to 500\$/unit depending on size, weight, and configuration of the item. Some items are actually systems that will require one or more pallets and one or more skids. Thus, the tabulation lists X Pallets + X Skids and total dollars. 


\section{SUMMARY OF APPLICABLE FEDERAL REGULATIONS FOR EQUIPMENT DISPOSITION}

Rocky Flats is a government-owned installation and therefore must adhere to the federal regulations governing the reporting, redistribution, and disposing of surplus government property. This Appendix summarizes these policies and pr. zedures regarding the economic and efficient utilization and disposition of property own by the Federal Government. There are two sets of regulations which apply:

41 CFR 101 - Federal Property Management Regulations

48 CFR 45.6 - Federal Acquisitions Regulations

Applicable sections from both are summarized here.

\section{CFR 45.603 Disposal Methods}

An agency may exercise its rights to require delivery of any contractor inventory. If the agency dose not exercise these rights, the contractor inventory shall be disposed of by one of the following methods in the priority indicated:

(a) Purchase or retention at cost by prime contractor or subcontractor of contractor-acquired property (45.605-1).

(b) Return of contractor-acquired property to suppliers (45.605-1).

(c) Use within the Government through the use of prescribed screening procedures (45.608).

(d) Donation to eligible donees (45.609).

(e) Sale (including purchase or retention at less than cost by the prime contractor or subcontractor) (45.610)

(f) Donation to public bodies in lieu of abandonment (45.611)

(g) Abandonment or destruction (45.611)

\section{CER 45.607 Scrap}

(a) The contractor need not itemize scrap on inventory schedules if (1) the material is physically segregated in the contractor's plant, and (2) the contractor submits a statement 
describing the material, estimating its cost, and providing other information necessary for the plant clearance officer to verify whether the property is scrap. The contractor shall sort the scrap to the extent economically feasible to assure the highest sale proceeds.

(b) the plant clearance officer shall review the schedules of property reported as scrap and if necessary, physically inspect the property involved. If the plant clearance officer determines that any of the property is serviceable, usable, or salvageable, the contractor shall resubmit it on appropriate inventory schedules.

\section{CFR 45.611 Destruction or Abandonment}

(a) Surplus property may be destroyed or abandoned only after every effort has been made to dispose of it by other authorized methods. Before authorization destruction of abandonment, the plant clearance officer shall determine in writing that:

(1) The property has no commercial value and no value to the gove:nrnent;

(2) The estimated cost of care and handling is greater than the probable sale price;

(3) Because of its nature, the property constitutes a danger to public health, safety, or welfare.

(b) Unless permitted by the contract, no contractor inventory shall be abandoned on the contractor's premises with out the contractor's written consent.

(c) Surplus property for which a determination has been made under subparagraph (a)(1) or (2) above may, however, be donated to public bodies in lieu of abandonment of destruction. All costs incident to donation shall be borne by the donee.

\section{CFR 45.613 Property Disposal Determination}

Written determination supporting abandonment, destruction, or other appropriate disposition shall be made by the plant clearance officer and reviewed by an appropriate reviewing authority within the agency.

\section{Sequence of Actions Concerning Utilization, Donation, and Sale of Government Property}

1. The agency determines that the property is no longer needed by it. In the case of RFP, the agency is DOE. This property is now considered to be EXCESS. 
2. The agency is then required to conduct such intermal agency screening as they deem necessary to reutilize the property within their agency.

(Reference 101-43.001-6 and 7).

3. Upon completion of internal screening, the agency is obligated to conduct Federal Agency Screening. This is usually accomplished by reporting the property to the General Services Administration (GSA) on SF 120, Report of Excess Property, for a 60-day screening period.

(Reference 101-42.304-1, $-2,-3$, and -4 , also sections 101-43.305 and 101-43.4801).

4. If the property is in the non-reportable category, it is still subject to local area screening. (Reference 101-43.4801).

5. After Federal Agency screening, the property is subject to donation screening for a period of 21 days. (Reference 101-44-.102). This applies whether the property is in the reportable or non-reportable category. The purpose of donation screening is to provide eligible entities to obtain the property prior to any sales action. Eligible entities are usually tax exempt activities, such as state agencies for surplus property.

6. After such screenings are completed, the property becomes SURPLUS by definition. (Reference 101-43.001-31).

7. At this point, the property is either sold or otherwise disposed of through the abandonment or destruction procedures.

(Reference 101-45.900).

8. These procedure contemplate the disposal of NRC property and other hazardous material through utilization, donation, or sale.

(Reference 101-42). 


\begin{tabular}{||l|l|l|l|l|l||}
\hline \multicolumn{5}{|c|}{ F.1 Equipment Selected for Government Use - Contaminated } \\
\hline Item & Manufacturer & Description & Item & Manufacturer & Description \\
\hline 40 & Pratt \& Whitney & 12" Lathe & 69 & Hardinge & Tool Room Lathe \\
\hline 47 & Bridgeport & Milling Machine & 70 & Hardinge & Tool Room Lathe \\
\hline 48 & Bridgeport & Milling Machine & 71 & Hardinge & Tool Room Lathe \\
\hline 49 & Bridgeport & Milling Machine & 72 & Bullard & Vertical Turret Lathe \\
\hline 50 & Bridgeport & Milling Machine & 100 & Sutton & 2000 T. Extrusion Press \\
\hline 51 & Bridgeport & Milling Machine & 120 & Autoslave & hot Isostatic Press \\
\hline 52 & Cinncinati & Milling Machine & 121 & Cinncinati & Hydorspin \\
\hline 55 & Walker-Turner & Drill Press & 135 & Stannet & Rolling Mill \\
\hline 56 & Darex & Drill Sharpener & 136 & Fenn & $7 "$, 18.4 H.P. Rolling Mill \\
\hline 57 & LeBlond & Engine Lathe & 137 & United & Rolling Mill \\
\hline 58 & Monarch & Engine Lathe, 16"x30" & 144 & Erie & Steam Forging Hammer \\
\hline 59 & Monarch & Engine Lathe, 16" & 145 & Fenn & Swager \\
\hline 60 & Monarch & Engine Lathe, 20" & 146 & Fenn & Swager, Large \\
\hline 61 & Monarch & Engine Lathe, 60" & 148 & Erie & Triple Action Press 150 T. \\
\hline 68 & Hardinge & Tool Room Lathe & 158 & Harwood & Cold Isostatic Press \\
\hline
\end{tabular}




\begin{tabular}{|c|c|c|c|c|c|}
\hline Item & Manufacturer & Description & Item & Manufacturer & Description \\
\hline 2 & Nikon & Camern & 78 & & Water Recirculator \\
\hline 3 & Polaroid & Carmera and Light Table & 79 & & RPT Orfice \\
\hline 4 & Vickers & Projection Mieroscope & 80 & Buebler & Abrasive Cutofl Saw (Small) \\
\hline$s$ & Bausch a Lomb & Meullograph & 81 & Noae & Be Preparation uBu Box \\
\hline 6 & Lew & metallograph & 82 & Detrex & Degreaser \\
\hline 7 & Wilson & Microbardness Tester & 83 & Mihwaukee & Grioder \\
\hline 8 & Buebler & Microhurdness Tester & 84 & & Sinks (2 each) \\
\hline 9 & Wilson & Microlurdaess Tester & 85 & Lindberg & Tube Furnace \& Evac. Assy \\
\hline 10 & Theta & Dilatometer & 86 & Continental & Abrasive Cut-off Saw, 34" \\
\hline 11 & Aulomel & AutomeV/Evromet Polisber & 87 & Hobart & Battery Charger ( 3 each) \\
\hline 11 & Leper & RF Geserator & 88 & None & Be Glovebox, inert \\
\hline 112 & Leco & Diamond Sawn (2 eacb) & 89 & Diversified Met & Be Preparation Box \\
\hline 13 & Newage & Rockwell Hardaess Tester & 90 & Mitwaukee & Bench Orinder \\
\hline 14 & Riehle & Rockwell Hardness Tester & 93 & Lindberg & Box Furace, Sola Basic 6" \\
\hline 15 & Clark lustr. Co & Rockwell Hardness Tester & 94 & Pexto & Circle Shear \\
\hline 16 & Wilson/Rochwell & Rockwell Hardness Texter & 95 & Barrett Powerox & Die Sucker \\
\hline 17 & & Hoods (2 each) & 96 & Fenn & Draw Beach \\
\hline 18 & Jarrett & Jarrett Polisber & 97 & Leland Gifford & Drill Press \\
\hline 19 & Leco & Grinder w/ Load Controller & 98 & Rockwell "Mil. & Drill Press \\
\hline 20 & Buebler & Abrasimet Saw & 99 & Lespold-Heraeus & Electron Beam Furnace \\
\hline 21 & & Polimet (3 each) griading wh & 101 & Automatic & Fork Truck \\
\hline 22 & & 120 Polimet Griader & 102 & Lewis-Sbepard & 20001b Cap Fork Truck \\
\hline 23 & Buebler & Abresimet uw & 103 & Allis Chaimen & 40001b Cap Fork Truck \\
\hline 24 & Instron Test & Test Machine and Controller & 104 & Lindberg & Furnace \\
\hline 25 & Buebler & Paeumet Mounting Press & 105 & Lindbers: & Furnace \\
\hline 26 & & Siak Mounted Press (2) & 109 & Vacuum Industri & Furnace \\
\hline 27 & MTS & Test Machine & 110 & Liadberg & 1370 C, 95 kW, Furaace \\
\hline 28 & MTS & Test Machine & 111 & Norton & Furnace, Hi-temp \\
\hline 29 & Buchler & Polimet Oriader & 112 & A Bar & $1200 \mathrm{C}$, Furmace High Vacuum \\
\hline 30 & Buebler & Vibromet Polisber & 113 & A Bar & $1600 \mathrm{C}$, Vacuum Furnace \\
\hline 31 & Buebler & Ultramet IV & 116 & Liquid Honing & Grit Balster, liquid \\
\hline 32 & Buebler & Vibromet & 117 & Peerlews & Hack Saw \\
\hline 33 & Lepel & RF Gewerator & 118 & Racine & Power Hack Sow \\
\hline
\end{tabular}




\begin{tabular}{|c|c|c|c|c|c|}
\hline 34 & Powermatic & Band Saw & 119 & Racine & Hack Saw \\
\hline 35 & & Bridgeport Mill & 122 & Lepel & laduction Coil \\
\hline 36 & Rochwell & Hardoes Tester & 125 & CEC & Leak Detector \\
\hline 37 & Buebler & Oriader Polisher & 126 & Varian & Leak Detector \\
\hline 38 & RochwelvDelu & Drill Press & 127 & Liff-A.Loft & S001b Capacity lifter \\
\hline 39 & & Grinder & 128 & OE of Canada & Manmate \\
\hline 41 & Perio Beverty & Haad Operated Shear & 129 & & Material Storage \\
\hline 42 & Dreis \& Krump & Street Metal Beader - 36" & 132 & Tinius Olson & Press, $60,00 \mathrm{lbs}$ \\
\hline 43 & & Tool Crib & 134 & Peck, Stow, w W & Roller Former - 20 G. Cap. \\
\hline 4 & Sureweld & Welder & 140 & Diacro & Sbear, \#4 \\
\hline 45 & Do.All & Band Saw & 141 & Lodge S Stuipley & Shear, $5 / 8$ inch $\& 9 \times 6^{\prime}$ \\
\hline 46 & Rochwell & Bell Sinder & 142 & Miller & Spot Welder, Resistance \\
\hline 53 & Abarboga Maskim & Drill Press & 143 & Vidmar & Stacker-retriever \\
\hline 54 & AlZ Meul & Drill Press & 147 & & Tooling Storage \\
\hline 62 & Racine & Hack Saw, 14" & 149 & Brew & Vacuum Furnace \\
\hline 63 & Black \& Decker & Pedestal Griader & 150 & Ajex Northrup & Vacuun Induction Furnace \\
\hline 64 & Hammond & Pedestal Grinder & 151 & & Waste Box Storage \\
\hline 65 & Baldor & Pedestal Grinder-Buffer & 152 & & Stepoff Pad \\
\hline 66 & Brown \& Sharpe & Surface Grinder * 618 Micro & 153 & Coulter Electro & Coulter Counter \\
\hline 67 & Cuner Master & Tool Grinder & 155 & Conway Pressure & Hot leosutic Press \\
\hline 73 & & Air Compressor & 159 & & Gas Botule Racks \\
\hline 74 & & Power Switches & 161 & Colmonoy & Flame Spray \& Hood \\
\hline 75 & & Pumps & 162 & Empire & Grit Blaster (Dual) \\
\hline 76 & & Steam Supply & & & \\
\hline$n$ & & Water Heater & & & \\
\hline
\end{tabular}


11
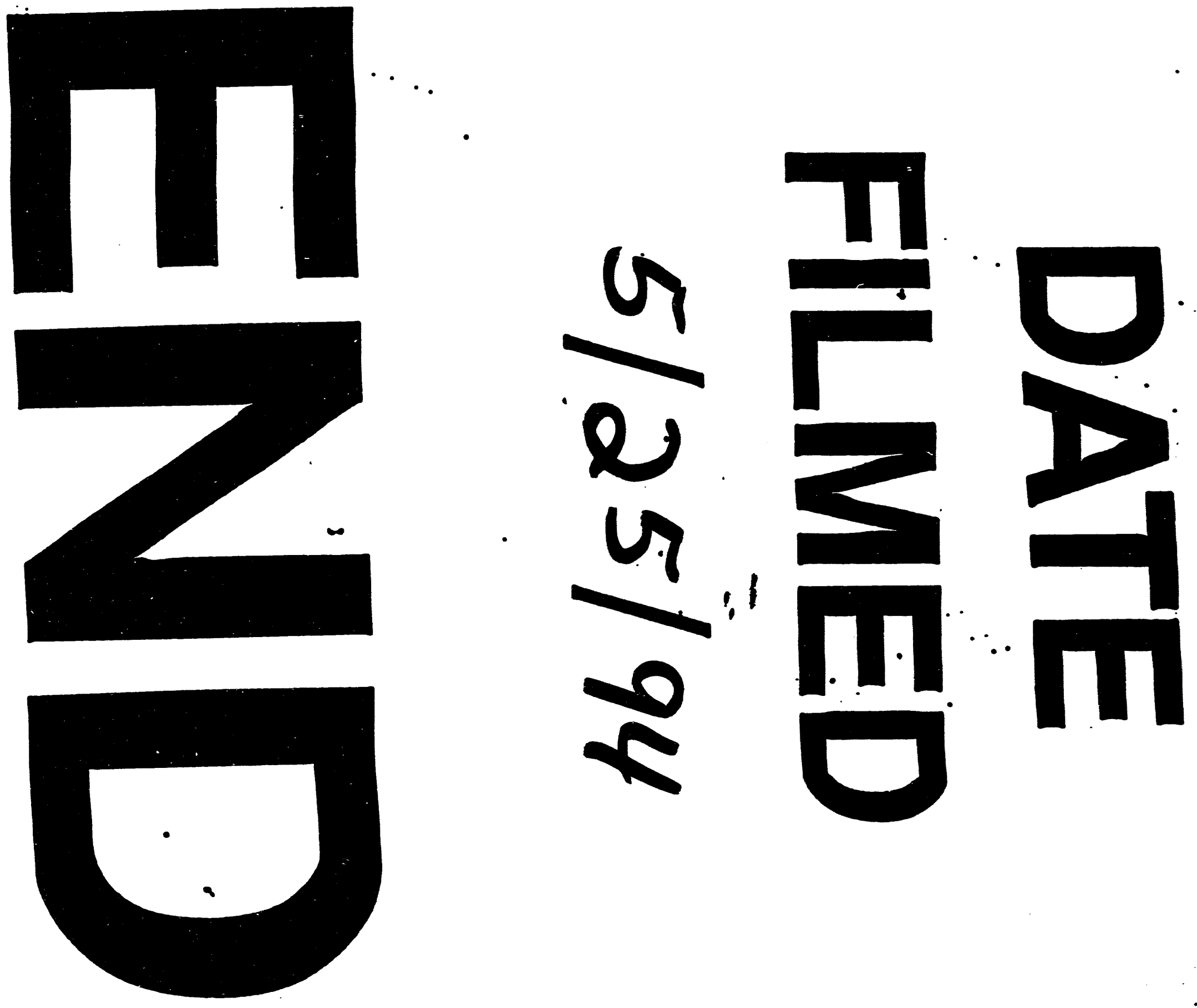
